\title{
Cooperative Si-H Addition to Side-On Ni(0)-Imine Complexes Forms Reactive Hydrosilazane Complexes
}

Dide G. A. Verhoeven, ${ }^{\mathrm{A}}$ Alessio F. Orsino, ${ }^{\mathrm{A}}$ Roel L. M. Bienenmann, ${ }^{\mathrm{A}}$ Martin Lutz, ${ }^{\mathrm{B}}$ MarcEtienne Moret ${ }^{A *}$

A Utrecht University, Organic Chemistry \& Catalysis, Debye Institute for Nanomaterials Science, Faculty of Science, Universiteitsweg 99, 3584 CG, Utrecht, The Netherlands, E-mail: M.Moret@uu.nl. ${ }^{\text {B Utrecht }}$ University, Crystal and Structural Chemistry, Bijvoet Center for Biomolecular Research, Faculty of Science, Padualaan 8, $3584 \mathrm{CH}$, Utrecht, The Netherlands.

1. Experimental 2

2. NMR spectra 5

3. IR spectra 18

4. X-ray crystallographic data 20

5. Additional discussions 22

6. Computational details 24

7. References 56 


\section{Experimental}

\section{General considerations}

All reagents were purchased from commercial sources and used as received unless stated otherwise. All reactions were performed in a $\mathrm{N}_{2}$ glovebox and at room temperature unless stated otherwise. Deuterated benzene $\left(\mathrm{C}_{6} \mathrm{D}_{6}\right)$ was degassed using the freeze-thaw-pump method $(4 \mathrm{x})$ and subsequently stored over molecular sieves. Tetrahydrofuran (THF) was distilled over sodium/benzophenone before use, both were degassed by bubbling $\mathrm{N}_{2}$ through it for 30 minutes and stored over molecular sieves. Dry diethylether $\left(\mathrm{Et}_{2} \mathrm{O}\right)$, hexanes and toluene were acquired from a MBRAUN MB SPS-80 solvent purification system and further dried over molecular sieves before use. Ligands $\mathbf{1}^{\mathrm{Ph}}, \mathbf{1}^{\mathrm{PhTol}}, \mathbf{1}^{\text {oTol }}$ and complexes $\mathbf{2}, \mathbf{3}$ and $\mathbf{4}$ were synthesized according to procedures described an earlier publication by us. [S1]

${ }^{1} \mathrm{H},{ }^{13} \mathrm{C},{ }^{29} \mathrm{Si}$ and ${ }^{31} \mathrm{P}$ NMR spectra (respectively 400, 100, 80 and $161 \mathrm{MHz}$ ) were recorded on an Agilent MRF400 or a Varian AS400 spectrometer at $25{ }^{\circ} \mathrm{C} .{ }^{1} \mathrm{H}$ and ${ }^{13} \mathrm{C}$ NMR chemical shifts are reported in ppm relative to TMS using the residual solvent resonance as internal standard. ${ }^{31} \mathrm{P}$ NMR chemical shifts are reported in ppm and externally referenced to $85 \%$ aqueous $\mathrm{H}_{3} \mathrm{PO}_{4}$ and ${ }^{29} \mathrm{Si}$ NMR chemical shifts are externally referenced to TMS. Infrared spectra were recorded using a Perkin Elmer Spectrum One FTIR spectrometer under a $\mathrm{N}_{2}$ flow. Compounds 2-4 were found to be too sensitive for obtaining accurate elemental analysis.

\section{Synthesis}

2[Si]: $\mathrm{Ni}\left(\mathrm{P}^{\mathrm{Ph}} \mathrm{CNP}^{\mathrm{Ph}}\right)\left(\mathrm{PPh}_{3}\right)(39.4 \mathrm{mg}, 0.045 \mathrm{mmol})$ was suspended in $\mathrm{C}_{6} \mathrm{H}_{6}(3 \mathrm{~mL})$. While stirring, $\mathrm{Ph}_{2} \mathrm{SiH}_{2}(9.2 \mu \mathrm{L}, 9.1 \mathrm{mg}, 0.050 \mathrm{mmol})$ was added and the mixture was stirred for $3 \mathrm{~h}$ during which the color changed from deep red to clear orange. All solvents were evaporated and the resulting yellow powder was washed with hexanes $(4 \times 1 \mathrm{~mL})$. The product was extracted using THF $(5 \mathrm{~mL})$ and filtered, after which it was dried. Addition of hexanes $(1 \mathrm{~mL})$ to the sticky yellow product induced precipitation, and (2[Si]) was isolated after evaporation of the solvent as a yellow powder with a yield of $85 \%(40.7$ $\mathrm{mg}, 0.039 \mathrm{mmol}) .{ }^{1} \mathrm{H} \mathrm{NMR}\left(\mathrm{C}_{6} \mathrm{D}_{6}\right): \delta_{\mathrm{H}} 8.04(\mathrm{~d}, J=8 \mathrm{~Hz}, 2 \mathrm{H}, \mathrm{Ar}-H), 7.55(\mathrm{t}, J=8 \mathrm{~Hz}, \mathrm{Ar}-H), 7.43$ (d, $J=7 \mathrm{~Hz}, \mathrm{Ar}-H), 7.38$ (dd, $J=5,8 \mathrm{~Hz}, \mathrm{Ar}-H), 7.16-6.92$ (m, Ar- $H$ ), 6.86 (dt, $J=2,7 \mathrm{~Hz}, \mathrm{Ar}-H), 6.82-$ $6.75(\mathrm{~m}, \mathrm{Ar}-H), 6.73-6.67(\mathrm{~m}, \mathrm{Ar}-H), 6.60(\mathrm{t}, J=7 \mathrm{~Hz}, \mathrm{Ar}-H), 6.53(\mathrm{t}, J=7 \mathrm{~Hz}, \operatorname{Ar}-H), 6.36$ (t, $J=7$ $\mathrm{Hz}, 1 \mathrm{H}, \mathrm{Ar}-H), 5.01\left(\mathrm{~d},{ }^{2} J_{\mathrm{HH}}=15 \mathrm{~Hz}, 1 \mathrm{H},-\mathrm{C} H_{2}\right), 4.61\left(\mathrm{dd},{ }^{2} J_{\mathrm{HH}}=2,15 \mathrm{~Hz}, 1 \mathrm{H},-\mathrm{C} H_{2}\right),-2.72$ (ddd, $\left.{ }^{2} J_{\mathrm{HP}}=19,23,36 \mathrm{~Hz}, 1 \mathrm{H}, \mathrm{Si}-H\right) \cdot{ }^{13} \mathrm{C} \mathrm{NMR}\left(\mathrm{C}_{6} \mathrm{D}_{6}\right): \delta_{\mathrm{C}} 156.15\left(\mathrm{~d}, J_{\mathrm{CP}}=18 \mathrm{~Hz}\right), 145.27\left(\mathrm{~d}, J_{\mathrm{CP}}=23 \mathrm{~Hz}\right)$, $144.05\left(\mathrm{~d}, J_{\mathrm{CP}}=5 \mathrm{~Hz}\right), 142.92,142.47\left(\mathrm{~d}, J_{\mathrm{CP}}=12 \mathrm{~Hz}\right), 140.45,139.86(\mathrm{~m}), 139.63(\mathrm{~m}), 139.07,138.77$, $136.49,136.32,136.16,135.50,135.30,134.96,134.71,134.58,133.79,133.72,133.67,133.59$, $133.55,133.43,133.32,133.23,133.20,132.56,132.44,132.10,131.78,129.95$ (m), 129.80, 129.51 (m), 128.92, 128.83, 128.60, 128.54, 128.47, 128.39, 128.18, 127.71, 127.42, 127.30, $127.22\left(\mathrm{~d}, J_{\mathrm{CP}}=\right.$ $1 \mathrm{~Hz}), 127.14,126.92,126.73,126.69,120.75\left(\mathrm{~d}, J_{\mathrm{CP}}=5 \mathrm{~Hz}\right) .{ }^{31} \mathrm{P} \mathrm{NMR}\left(\mathrm{C}_{6} \mathrm{D}_{6}\right): \delta_{\mathrm{P}} 32.78\left(\mathrm{~d},{ }^{2} J_{\mathrm{PP}}=17\right.$ $\mathrm{Hz}), 17.06\left(\mathrm{dd},{ }^{2} J_{\mathrm{PP}}=17,45 \mathrm{~Hz}\right), 7.82\left(\mathrm{~d},{ }^{2} J_{\mathrm{PP}}=45 \mathrm{~Hz}\right) \cdot{ }^{29} \mathrm{Si} \mathrm{NMR}\left(\mathrm{C}_{6} \mathrm{D}_{6}\right): \delta_{\mathrm{Si}} 6.45\left(\mathrm{ddd}, J_{\mathrm{SiP}}=2,17\right.$, $60 \mathrm{~Hz}, \mathrm{Si}-\mathrm{H})$. IR cm ${ }^{-1}: 3052$, 2923, 2853, 1955, 1893, 1816, 1664, 1584, 1467, 1433, 1263, 1184, 1117 , $1093,1027,868,822,740,695,519,508,486$.

3[Si]: $\mathrm{Ni}\left(\mathrm{P}^{o \text { Tol }} \mathrm{CNP}^{\mathrm{Ph}}\right)\left(\mathrm{PPh}_{3}\right)(17.9 \mathrm{mg}, 0.0199 \mathrm{mmol})$ was suspended in $\mathrm{C}_{6} \mathrm{H}_{6}(1 \mathrm{~mL})$. While stirring, $\mathrm{Ph}_{2} \mathrm{SiH}_{2}(4.4 \mu \mathrm{L}, 4.4 \mathrm{mg}, 0.024 \mathrm{mmol})$ was added and the mixture was stirred for $2.5 \mathrm{~h}$ during which the color changed from deep red to clear orange. All solvents were evaporated and the resulting yellow powder was washed with hexanes $(4 \times 1 \mathrm{~mL})$. The product was extracted using THF $(3 \mathrm{~mL})$ and filtered, after which it was dried. Addition of hexanes $(0.5 \mathrm{~mL})$ to the sticky yellow product induced precipitation, and $(\mathbf{3}[\mathbf{S i}])$ was isolated after evaporation of the solvent as a yellow powder with a yield of 90\% (19.4 mg, $0.018 \mathrm{mmol}) .{ }^{1} \mathrm{H} \mathrm{NMR}\left(\mathrm{C}_{6} \mathrm{D}_{6}\right): \delta_{\mathrm{H}} 7.57$ (d, $\left.J=5 \mathrm{~Hz}, \mathrm{Ar}-H\right), 7.34$ (t, $\left.J=9 \mathrm{~Hz}, \mathrm{Ar}-H\right)$, 7.05-6.99 (m, Ar-H), 6.94-6.77 (m, Ar- $H), 6.39$ (t, $J=7 \mathrm{~Hz}, \mathrm{Ar}-H), 4.92$ (s, broad, $-\mathrm{CH}$ ), $2.43(\mathrm{~s}, 6 \mathrm{H}$, 
$o$ Tol- $\left.\mathrm{CH}_{3}\right),-4.35\left(\mathrm{dd},{ }^{2} J_{\mathrm{HP}}=19,92 \mathrm{~Hz}, \mathrm{Si}-H\right) .{ }^{13} \mathrm{C} \mathrm{NMR}\left(\mathrm{C}_{6} \mathrm{D}_{6}\right): \delta_{\mathrm{C}} 155.10\left(\mathrm{~d}, J_{\mathrm{CP}}=10 \mathrm{~Hz}\right), 144.58$, $144.38,136.26,135.42,134.19\left(\mathrm{~d}, J_{\mathrm{CP}}=15 \mathrm{~Hz}\right), 133.69\left(\mathrm{~d}, J_{\mathrm{CP}}=4 \mathrm{~Hz}\right), 132.14,131.53,130.41\left(\mathrm{~d}, J_{\mathrm{CP}}\right.$ $=5 \mathrm{~Hz}), 130.10,129.27,129.06,128.67,128.60,128.48,128.39,127.62,127.30\left(\mathrm{~d}, J_{\mathrm{CP}}=4 \mathrm{~Hz}\right), 126.61$, 126.51, 121.90, 121.39, 120.04, $117.81\left(\mathrm{~d}, J_{\mathrm{CP}}=7 \mathrm{~Hz}\right), 50.91\left(\mathrm{~d}, J_{\mathrm{CP}}=29 \mathrm{~Hz}\right), 21.39$ (d, $\left.J_{\mathrm{CP}}=22 \mathrm{~Hz}\right)$. ${ }^{31} \mathrm{P}$ NMR $\left(\mathrm{C}_{6} \mathrm{D}_{6}\right)$ : $\delta_{\mathrm{P}} 27.38,22.02,-31.67 .{ }^{29} \mathrm{Si} \mathrm{NMR}\left(\mathrm{C}_{6} \mathrm{D}_{6}\right)$ : no signal obtained due to low solubility of the material.

4[Si]: $\mathrm{Ni}\left(\mathrm{P}^{o T o l} \mathrm{CNP}^{o T o l}\right)\left(\mathrm{PPh}_{3}\right)(16.5 \mathrm{mg}, 0.0178 \mathrm{mmol})$ was suspended in $\mathrm{C}_{6} \mathrm{H}_{6}(1 \mathrm{~mL})$. While stirring, $\mathrm{Ph}_{2} \mathrm{SiH}_{2}$ (4 $\mu \mathrm{L}, 3.97 \mathrm{mg}, 0.022 \mathrm{mmol}$ ) was added and the mixture was stirred for $2.5 \mathrm{~h}$ during which the color changed from deep red to clear orange. All solvents were evaporated and the resulting yellow powder was washed with hexanes $(4 \times 1 \mathrm{~mL})$. The product was extracted using THF $(3 \mathrm{~mL})$ and filtered, after which it was dried. Addition of hexanes $(0.5 \mathrm{~mL})$ to the sticky yellow product induced precipitation, and $4[\mathbf{S i}]$ was isolated after evaporation of the solvent as a yellow powder with a yield of $71 \%$ (14.1 mg, $0.013 \mathrm{mmol}) .{ }^{1} \mathrm{H}$ NMR $\left(\mathrm{C}_{6} \mathrm{D}_{6}\right): \delta_{\mathrm{H}} 7.48-7.44(\mathrm{~m}, \mathrm{Ar}-H), 7.36(\mathrm{~s}, \mathrm{Ar}-H), 7.26(\mathrm{t}, J=8$ $\mathrm{Hz}, \mathrm{Ar}-H), 7.19$ (s, Ar-H), 7.09-6.98 (m, Ar-H), 6.96-6.80 (m, Ar-H), 6.77-6.73 (m, Ar-H), 6.69-6.66 (m, Ar-H), $6.50(\mathrm{~s}, \mathrm{Ar}-H), 6.44-6.40(\mathrm{~m}, \mathrm{Ar}-H), 4.84-4.78\left(\mathrm{~m},-\mathrm{CH}_{2}\right), 4.65-4.60\left(\mathrm{~m},-\mathrm{CH}_{2}\right), 2.57$ (s, $\left.3 \mathrm{H}, o \mathrm{Tol}-\mathrm{CH}_{3}\right), 2.52\left(\mathrm{~s}, 3 \mathrm{H}, o \mathrm{Tol}-\mathrm{CH}_{3}\right), 2.45\left(\mathrm{~s}, 3 \mathrm{H}, o \mathrm{Tol}-\mathrm{CH}_{3}\right), 2.33\left(\mathrm{~s}, 3 \mathrm{H}, o\right.$ Tol- $\left.\mathrm{CH}_{3}\right),-5.53$ (dd, $\left.{ }^{2} J_{\mathrm{HP}}=19,85 \mathrm{~Hz}, 1 \mathrm{H}, \mathrm{Si}-H\right) .{ }^{13} \mathrm{C} \mathrm{NMR}\left(\mathrm{C}_{6} \mathrm{D}_{6}\right)$ : quality is poor due to low solubility of the compound. ${ }^{31} \mathrm{P}$ NMR $\left(\mathrm{C}_{6} \mathrm{D}_{6}\right)$ : $\delta_{\mathrm{P}} 26.02,4.85,-31.24 .{ }^{29} \mathrm{Si} \mathrm{NMR}\left(\mathrm{C}_{6} \mathrm{D}_{6}\right)$ : no signal obtained due to low solubility of the material. IR cm ${ }^{-1}: 3050,1862$ (hydridic signal), 1580, 1467, 1449, 1433, 1377, 1283, 1231, 1095, $1034,849,803,745,693,677,576,557,519,500,487,456,429$.

2[SiPhMe]: $\mathrm{Ni}\left(\mathrm{P}^{\mathrm{Ph}} \mathrm{CNP}^{\mathrm{Ph}}\right)\left(\mathrm{PPh}_{3}\right)(14.7 \mathrm{mg}, 0.017 \mathrm{mmol})$ was suspended in $\mathrm{C}_{6} \mathrm{H}_{6}(1 \mathrm{~mL})$. While stirring, $\mathrm{Ph}_{2} \mathrm{SiH}_{2}(3.3 \mu \mathrm{L}, 3.3 \mathrm{mg}, 0.018 \mathrm{mmol})$ was added and the mixture was stirred for $3 \mathrm{~h}$ during which the color changed from turbid red to clear orange. All solvents were evaporated and the resulting powder was washed with hexanes $(2 \times 1 \mathrm{~mL})$. The solids were dried in vacuum and 2[SiPhMe] was isolated an off-white powder in quantitative yield. Single crystals for XRD analysis were grown from slow vapor diffusion of hexanes into a concentrated solution of the product in benzene. ${ }^{1} \mathrm{H} N M R\left(\mathrm{C}_{6} \mathrm{D}_{6}\right): \delta_{\mathrm{H}} 8.04$ (d, $J=6 \mathrm{~Hz}, \mathrm{Ar}-H$ ), 7.82 (t, $J=8 \mathrm{~Hz}, \mathrm{Ar}-H), 7.59$ (small, broad, Ar-H), 7.51-7.45 (m, Ar-H), 7.40 (t, $J=8 \mathrm{~Hz}, \mathrm{Ar}-H), 7.30-7.18$ (m, Ar-H), 7.13-6.77 (m, Ar-H), 6.73-6.69 (m, Ar- $H), 6.63-6.57$ (m, Ar$H), 6.55-6.49(\mathrm{~m}, \mathrm{Ar}-H), 6.29$ (t, $J=6 \mathrm{~Hz}, \mathrm{Ar}-H), 6.00(\mathrm{t}, J=5 \mathrm{~Hz}, \mathrm{Ar}-H), 5.02\left(\mathrm{~d},{ }^{2} J_{\mathrm{HH}}=15 \mathrm{~Hz}\right.$, minor species, $\left.-\mathrm{CH}_{2}\right), 4.79\left(\mathrm{~d},{ }^{2} J_{\mathrm{HH}}=15 \mathrm{~Hz}\right.$, major species, $\left.-\mathrm{CH}_{2}\right), 4.53\left(\mathrm{~d},{ }^{2} J_{\mathrm{HH}}=15 \mathrm{~Hz}\right.$, minor species, $\left.-\mathrm{CH}_{2}\right), 4.40\left(\mathrm{~d},{ }^{2} J_{\mathrm{HH}}=15 \mathrm{~Hz}\right.$, major species, $-\mathrm{CH}_{2}$ ), 0.68 (s, major species, $-\mathrm{Me}$ ), 0.44 (s, minor species, $-\mathrm{Me}),-2.52\left(\mathrm{ddd},{ }^{2} J_{\mathrm{HP}}=35,24,11 \mathrm{~Hz}\right.$, major species, $\left.\mathrm{Si}-H\right),-2.84\left(\mathrm{ddd},{ }^{2} J_{\mathrm{HP}}=36,21,8 \mathrm{~Hz}\right.$, minor species, $\mathrm{Si}-H$ ). Broadband ${ }^{31} \mathrm{P}$ decoupled NMR from $\delta-4$ to $-2:-2.52$ (major, s, ${ }^{29} \mathrm{Si}$-satellites: $J_{\mathrm{HSi}}=$ $111 \mathrm{~Hz}$ ), -2.84 (minor, s, ${ }^{29}$ Si-satellites: $\left.J_{\mathrm{HSi}}=102 \mathrm{~Hz}\right) .{ }^{13} \mathrm{C}$ NMR $\left(\mathrm{C}_{6} \mathrm{D}_{6}\right): \delta_{\mathrm{C}} 155.70,155.54,145.80$, $145.58,144.79,144.22,143.95,142.71,142.02,141.89,139.88,139.64,139.24,137.68,135.22$, $135.08,134.76,134.60,134.38,134.25,133.71,133.09,132.59,132.47,132.35,132.23,129.96$, $129.71,129.35,128.58,128.43,127.71,127.64,127.51,127.39,127.26,127.04,126.71,125.87$, $125.71,121.46,120.20,56.03,54.23,9.20 .{ }^{31} \mathrm{P}$ NMR $\left(\mathrm{C}_{6} \mathrm{D}_{6}\right): \delta_{\mathrm{P}} 33.29\left(\mathrm{~A}, \mathrm{dd},{ }^{2} J_{\mathrm{pp}}=3,16 \mathrm{~Hz}\right), 30.28$ $\left(\mathrm{B}, \mathrm{dd},{ }^{2} J_{\mathrm{pp}}=5,16 \mathrm{~Hz}\right), 17.94\left(\mathrm{~B}, \mathrm{dd},{ }^{2} J_{\mathrm{pp}}=16,48 \mathrm{~Hz}\right), 17.52\left(\mathrm{~A}, \mathrm{dd},{ }^{2} J_{\mathrm{pp}}=16,45 \mathrm{~Hz}\right), 10.43$ (B, dd, $\left.{ }^{2} J_{\mathrm{pp}}=5,48 \mathrm{~Hz}\right), 7.78\left(\mathrm{~A}, \mathrm{dd},{ }^{2} J_{\mathrm{pp}}=3,45 \mathrm{~Hz}\right) .{ }^{29} \mathrm{Si} \mathrm{NMR}\left(\mathrm{C}_{6} \mathrm{D}_{6}\right): \delta_{\mathrm{Si}}-3.19\left(\mathrm{dd},{ }^{2} J_{\mathrm{SiP}}=14,53 \mathrm{~Hz}\right),-8.32$ (ddd, $\left.{ }^{2} J_{\mathrm{SiP}}=4,15,43 \mathrm{~Hz}\right)$.

Standard synthesis for isolated deuterated complexes: The nickel starting complex (2, 3 or $\mathbf{4}, 4$ to 6 $\mathrm{mg}$ ) was weighed in a small vial and suspended in $\mathrm{C}_{6} \mathrm{H}_{6}(1 \mathrm{~mL})$. While stirring, $\mathrm{Ph}_{2} \mathrm{SiD}_{2}(1.05 \mathrm{eq})$ was added. After 2-3 hours, as indicated by the color and physical change of the mixture from a dark red suspension to an orange solution, the solvent was evaporated. Hexanes $(2 \mathrm{~mL})$ was added, if necessary 
the mixture was cooled to $-35^{\circ} \mathrm{C}$, and removed by decantation followed by evaporation of remaining volatiles in vacuum. All reactions lead to quantitative yields.

2[SiD $\mathbf{S i D}_{2}$ ]: Standard procedure followed. ${ }^{1} \mathrm{H}$ NMR $\left(\mathrm{C}_{6} \mathrm{D}_{6}\right): \delta_{\mathrm{H}} 8.04(\mathrm{~d}, J=7.07 \mathrm{~Hz}, \mathrm{Ar}-H, 2 \mathrm{H}), 7.55(\mathrm{t}, J$ $=8 \mathrm{~Hz}, \operatorname{Ar}-H), 7.42(\mathrm{~d}, J=7 \mathrm{~Hz}, \operatorname{Ar}-H), 7.13-6.92(\mathrm{~m}, \mathrm{Ar}-H), 6.87(\mathrm{dt}, J=2,7 \mathrm{~Hz}, \operatorname{Ar}-H), 6.82-6.68$ (m, Ar-H), $6.60(\mathrm{t}, J=7 \mathrm{~Hz}, \mathrm{Ar}-H), 6.53(\mathrm{t}, J=8 \mathrm{~Hz}, \mathrm{Ar}-H), 6.37$ (t, $J=7 \mathrm{~Hz}, \mathrm{Ar}-H, 1 \mathrm{H}), 4.99$ (s, $\mathrm{CDH}, 0.5 \mathrm{H}), 4.60(\mathrm{~d}, J=2 \mathrm{~Hz},-\mathrm{CD} H, 0.5 \mathrm{H}) .{ }^{2} \mathrm{H}$ NMR $\left(\mathrm{C}_{6} \mathrm{D}_{6}\right): \delta_{\mathrm{H}} 5.05\left(\mathrm{Ph}_{2} \mathrm{SiH} D\right), 4.55$ (broad, $\mathrm{CH} D),-2.65(\mathrm{Si}-D-\mathrm{N}) .{ }^{13} \mathrm{C}$ NMR $\left(\mathrm{C}_{6} \mathrm{D}_{6}\right): \delta_{\mathrm{C}} 156.11(\mathrm{~d}, J=16 \mathrm{~Hz}), 145.25(\mathrm{~d}, J=24 \mathrm{~Hz}), 143.98$, $142.82,142.41$ (d, $J=10 \mathrm{~Hz}), 139.87,139.63,139.07,138.77,136.06,135.31,134.95,134.70,134.58$, $133.72,133.59,133.19,132.56,132.44,130.56,130.13,129.80,129.33,128.57,127.43,127.30$, 127.22, 127.14, 127.06, 126.92, $126.72(\mathrm{~d}, \mathrm{~J}=5 \mathrm{~Hz}), 125.70,120.76(\mathrm{~d}, J=4 \mathrm{~Hz}), 100.57 .{ }^{31} \mathrm{P}$ NMR $\left(\mathrm{C}_{6} \mathrm{D}_{6}\right): \delta_{\mathrm{P}} 32.69\left(\mathrm{~d},{ }^{2} J_{\mathrm{PP}}=17 \mathrm{~Hz}\right), 17.09\left(\mathrm{dd},{ }^{2} J_{\mathrm{PP}}=17,45 \mathrm{~Hz}\right), 7.77\left(\mathrm{dd},{ }^{2} J_{\mathrm{PP}}=4,45 \mathrm{~Hz}\right) .{ }^{29} \mathrm{Si} \mathrm{NMR}$ $\left(\mathrm{C}_{6} \mathrm{D}_{6}\right)$ : no signal obtained due to low solubility of the material. IR $\mathrm{cm}^{-1}: 3052,2961,2923,2854,1667$, $1585,1556,1479,1467,1433,1307,1261,1184,1157,1118,1090,1027,824,802,739,695,617$, $542,519,506,488,409$.

3[SiD $\mathbf{S i D}_{2}$ ]: Standard procedure followed. ${ }^{1} \mathrm{H}$ NMR $\left(\mathrm{C}_{6} \mathrm{D}_{6}\right)$ : $\delta_{\mathrm{H}} 7.57$ (broad s, $\left.\mathrm{Ar}-H\right), 7.33(\mathrm{t}, J=8 \mathrm{~Hz}, \mathrm{Ar}-$ $H), 7.18-7.10(\mathrm{~m}, \mathrm{Ar}-H), 7.05-6.99$ (m, Ar-H), 6.94-6.79 (m, Ar-H), 6.39 (t, $J=7 \mathrm{~Hz}, \mathrm{Ar}-H), 4.88$ (broad s, $\left.-\mathrm{CH}_{2}\right), 2.43\left(\mathrm{~s}, 3 \mathrm{H},-\mathrm{CH}_{3}\right) .{ }^{31} \mathrm{P} \mathrm{NMR}\left(\mathrm{C}_{6} \mathrm{D}_{6}\right)$ : $\delta_{\mathrm{P}} 27.44,21.98,-31.64$.

4[SiD $\mathbf{S i D}_{2}$ : Standard procedure followed. ${ }^{1} \mathrm{H}$ NMR $\left(\mathrm{C}_{6} \mathrm{D}_{6}\right)$ : $\delta_{\mathrm{H}} 7.46($ broad s, $\mathrm{Ar}-H), 7.26(\mathrm{t}, J=8 \mathrm{~Hz}, \mathrm{Ar}-$ $H$ ), 7.19 (broad s, Ar-H), 7.13 (broad s, Ar-H), 7.09-6.80 (broad m, Ar-H), 6.75 (broad s, Ar-H), 6.68 (broad s, Ar-H), 6.50 (broad s, Ar-H), 6.42 (broad s, Ar-H), 4.79 (broad s, $-\mathrm{CH}_{2}$ ), 4.61 (broad s, $\mathrm{CH}_{2}$ ), 2.57 (broad s, $-\mathrm{CH}_{3}$ ), 2.52 (broad s, $\left.-\mathrm{CH}_{3}\right), 2.45$ (broad s, $\left.-\mathrm{CH}_{3}\right), 2.33$ (broad s, $-\mathrm{CH}_{3}$ ). ${ }^{31} \mathrm{P}$ NMR $\left(\mathrm{C}_{6} \mathrm{D}_{6}\right): \delta_{\mathrm{P}} 26.09,4.81,-31.25$.

Standard synthesis for in situ formed complexes and stoichiometric reactions: the Ni-complex suspended in $\mathrm{C}_{6} \mathrm{H}_{6}(0.6 \mathrm{~mL})$. While stirring, the silane (1 equivalent) was added using a microsyringe and the mixture was stirred for $>30$ min, until full color change was observed from deep red to clear orange. 


\section{NMR spectra}

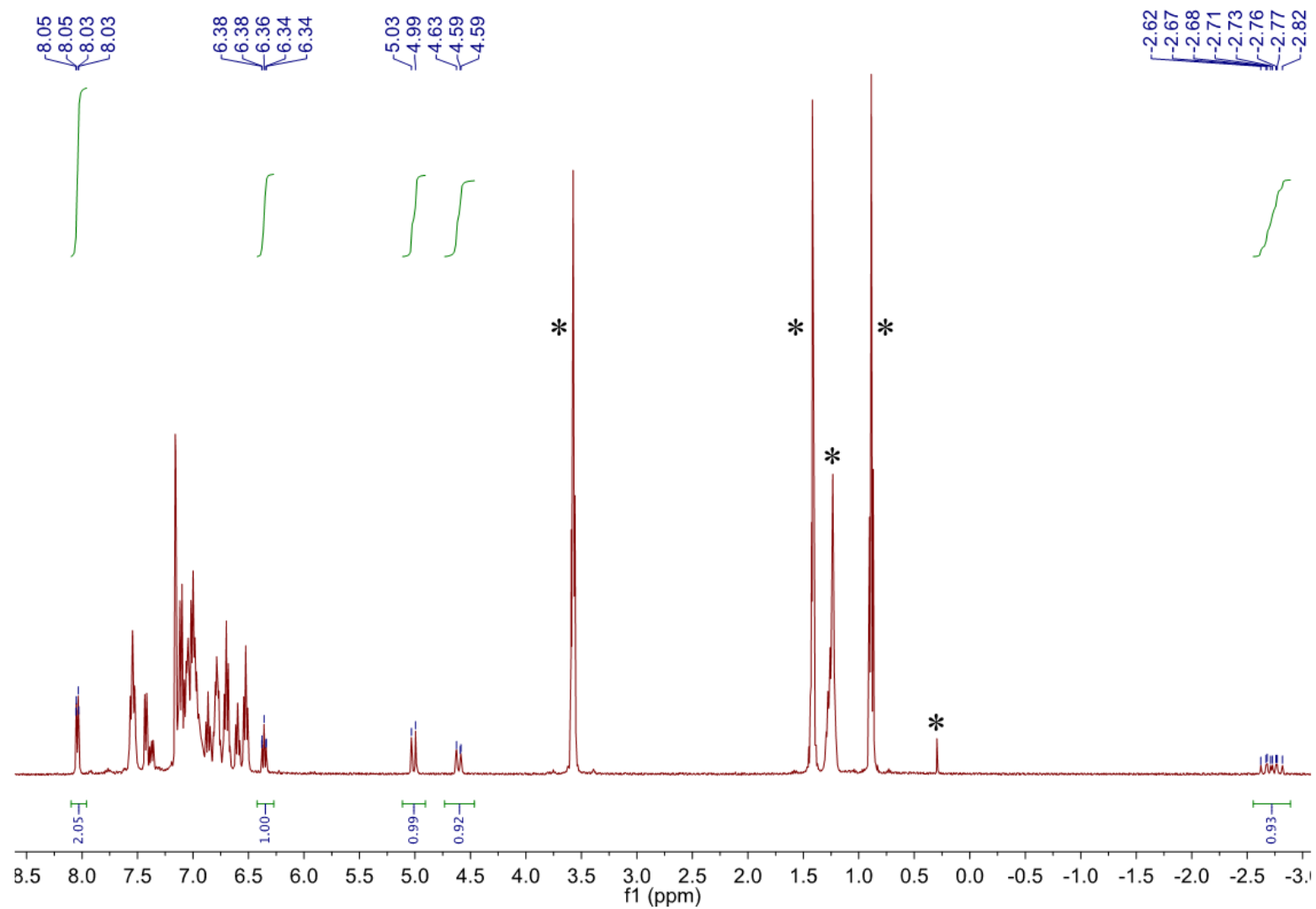

Figure S1. ${ }^{1} \mathrm{H}$ NMR spectrum $\left(\mathrm{C}_{6} \mathrm{D}_{6}\right)$ of $\mathrm{Ni}\left(\mathrm{P}^{\mathrm{Ph}} \mathrm{CNP}^{\mathrm{Ph}}\right)\left(\mathrm{PPh}_{3}\right)\left(\mathrm{Ph}_{2} \mathrm{SiH}_{2}\right)$ 2[Si]. The signals marked with * originate from solvents (THF, hexanes and grease).

a)

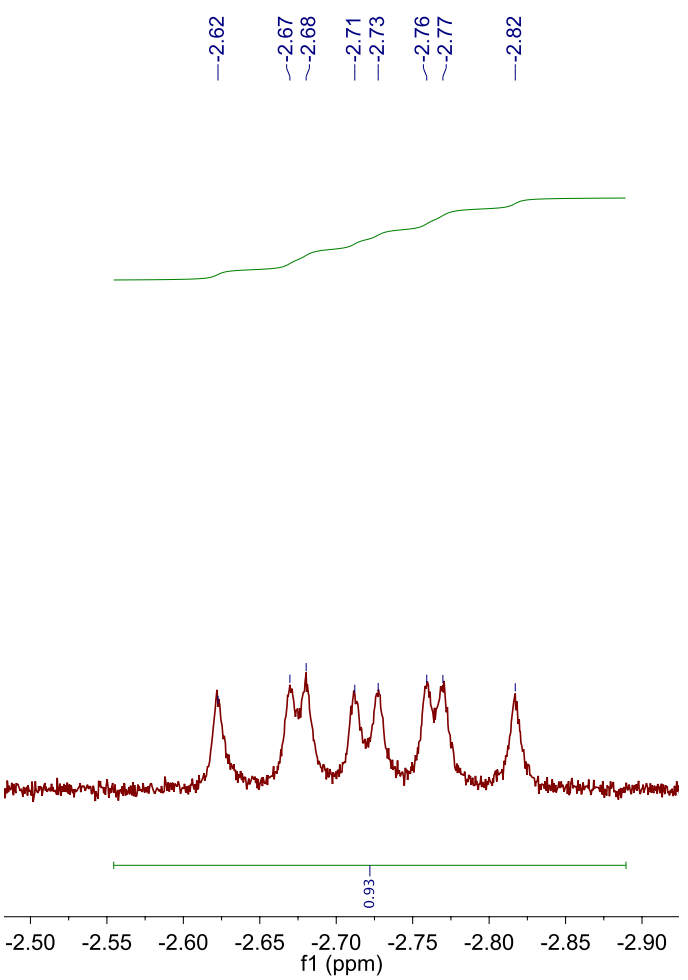

b)

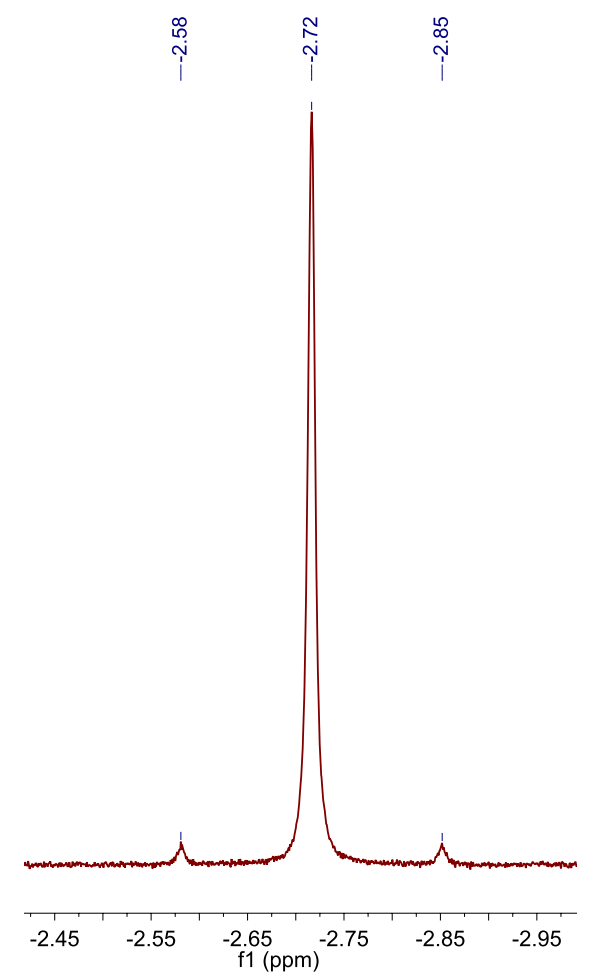

Figure S2. Zoom of the hydride signal ${ }^{1} \mathrm{H}$ NMR spectrum $\left(\mathrm{C}_{6} \mathrm{D}_{6}\right)$ of $\mathrm{Ni}\left(\mathrm{P}^{\mathrm{Ph}} \mathrm{CNP}^{\mathrm{Ph}}\right)\left(\mathrm{PPh}_{3}\right)\left(\mathrm{Ph}_{2} \mathrm{SiH}_{2}\right) 2[\mathrm{Si}]$. a) ${ }^{1} \mathrm{H}$ NMR ${ }^{31} \mathrm{P}$ coupled, b) ${ }^{1} \mathrm{H}$ NMR ${ }^{31} \mathrm{P}$ decoupled. 


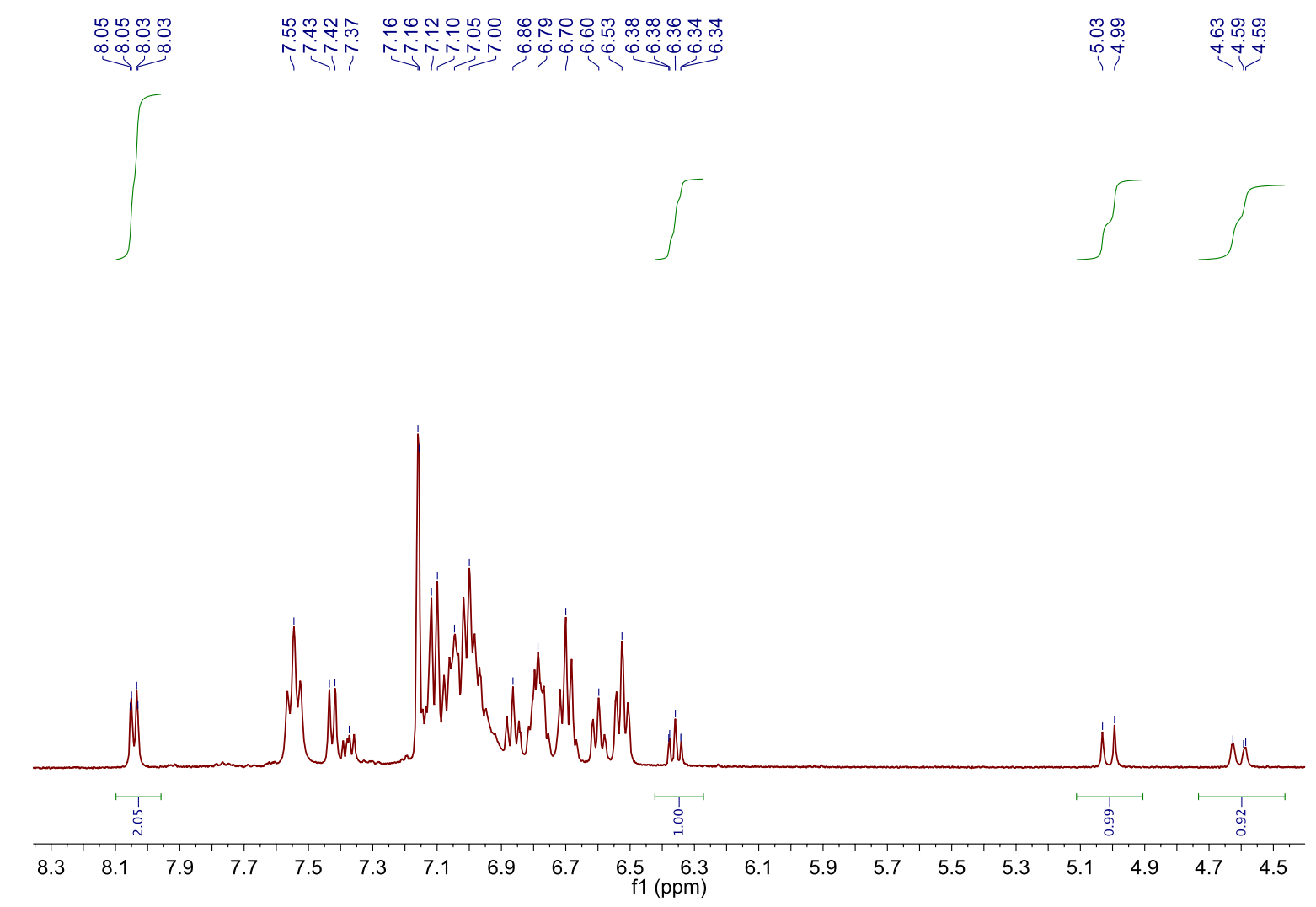

Figure S3. Zoom of the ${ }^{1} \mathrm{H}$ NMR spectrum $\left(\mathrm{C}_{6} \mathrm{D}_{6}\right)$ of $\mathrm{Ni}\left(\mathrm{P}^{\mathrm{Ph}} \mathrm{CNP}^{\mathrm{Ph}}\right)\left(\mathrm{PPh}_{3}\right)\left(\mathrm{Ph}_{2} \mathrm{SiH}_{2}\right) \mathbf{2}[\mathrm{Si}]$.

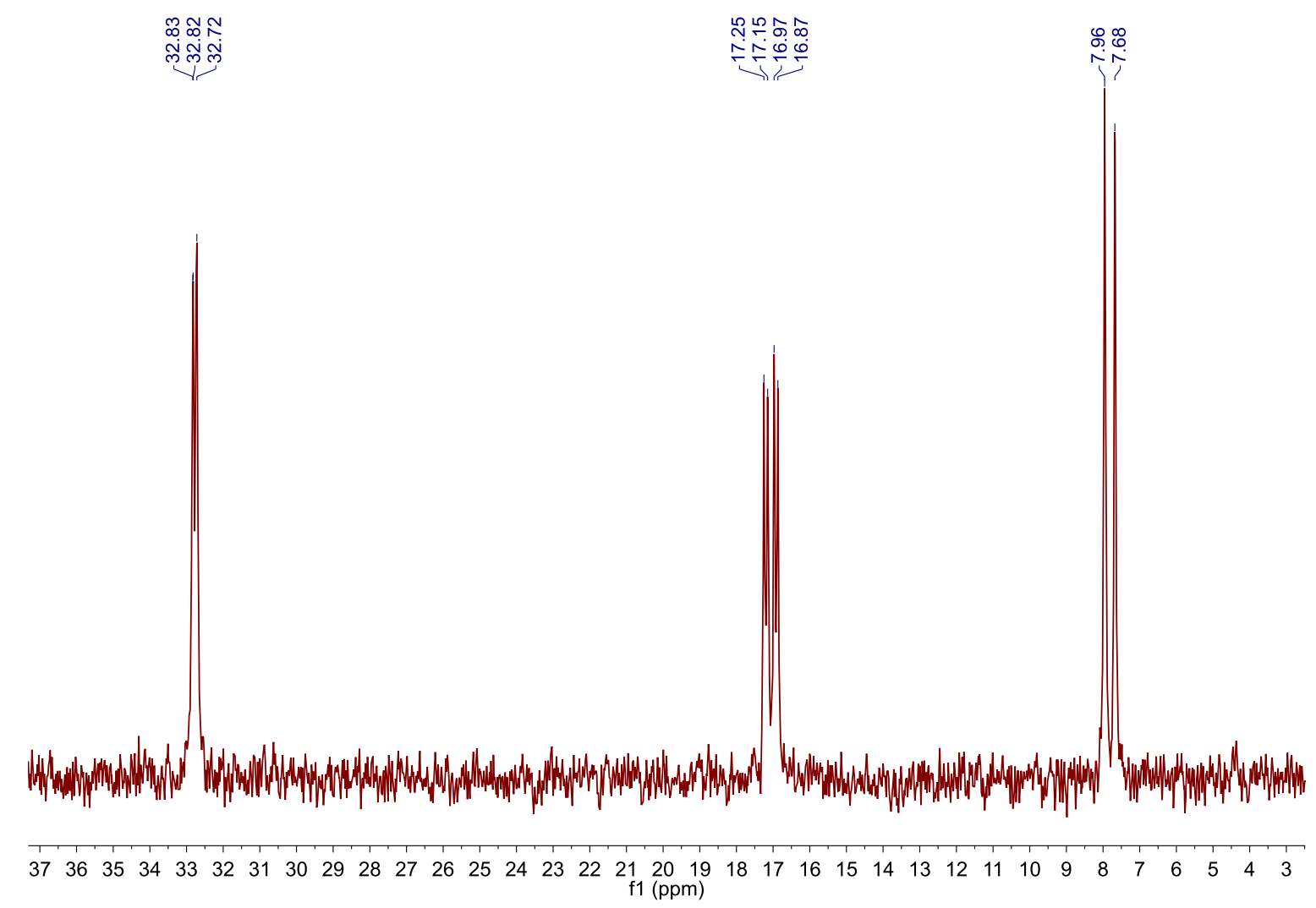

Figure S4. ${ }^{31} \mathrm{P}$ NMR spectrum $\left(\mathrm{C}_{6} \mathrm{D}_{6}\right)$ of $\mathrm{Ni}\left(\mathrm{P}^{\mathrm{Ph}} \mathrm{CNP}^{\mathrm{Ph}}\right)\left(\mathrm{PPh}_{3}\right)\left(\mathrm{Ph}_{2} \mathrm{SiH}_{2}\right) 2[\mathbf{S i}]$. 

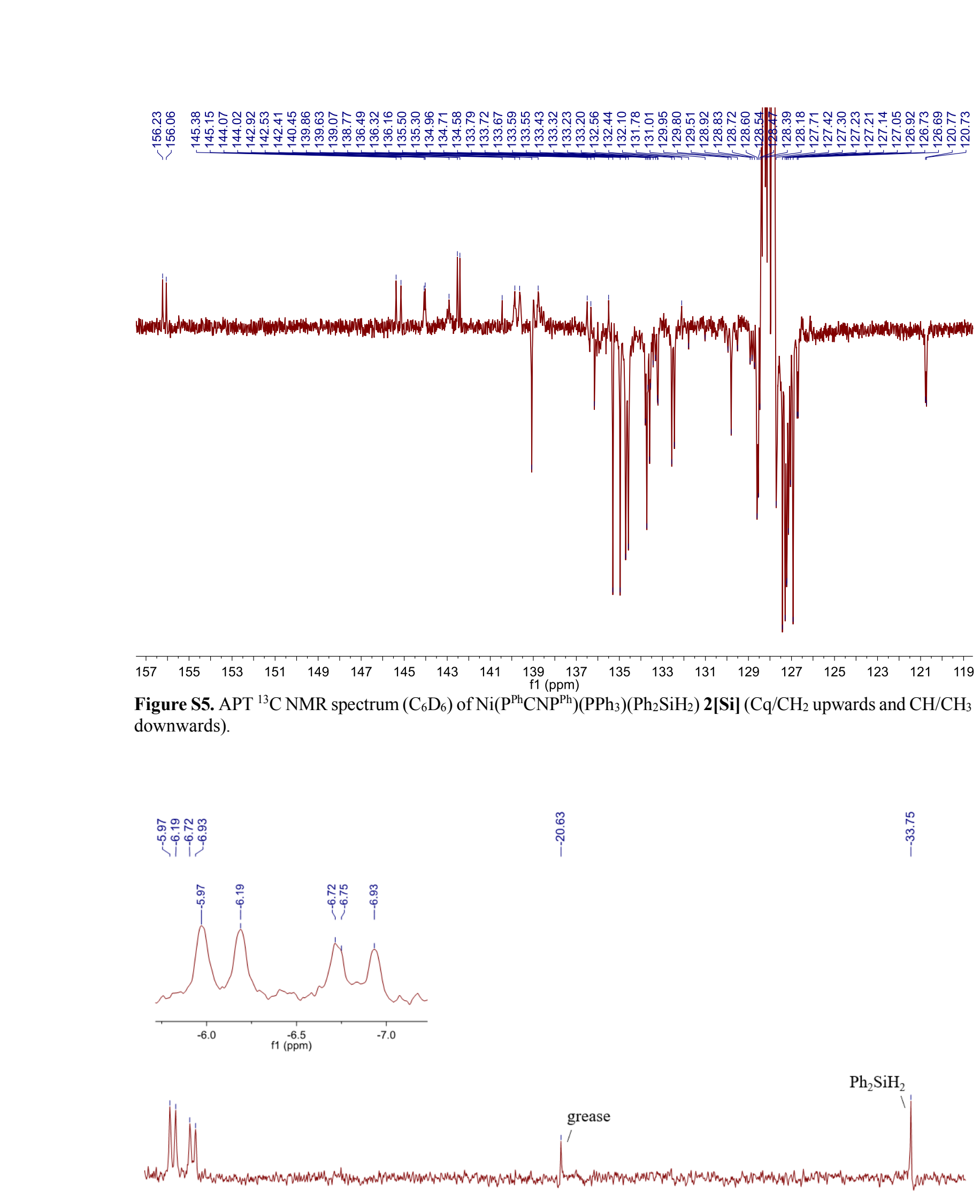

Figure S5. APT ${ }^{13} \mathrm{C}$ NMR spectrum $\left(\mathrm{C}_{6} \mathrm{D}_{6}\right)$ of $\mathrm{Ni}\left(\mathrm{P}^{\mathrm{Ph}} \mathrm{CNP}^{\mathrm{Ph}}\right)\left(\mathrm{PPh}_{3}\right)\left(\mathrm{Ph}_{2} \mathrm{SiH}_{2}\right) 2[\mathrm{Si}]\left(\mathrm{Cq} / \mathrm{CH}_{2}\right.$ upwards and $\mathrm{CH} / \mathrm{CH}_{3}$ downwards).

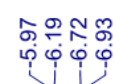

$\begin{array}{llllllllllllllllllllllllllllllll}-6 & -7 & -8 & -9 & -10 & -11 & -12 & -13 & -14 & -15 & -16 & -17 & -18 & -19 & -20 & -21 & -22 & -23 & -24 & -25 & -26 & -27 & -28 & -29 & -30 & -31 & -32 & -33 & -34 & -35\end{array}$

Figure S6. ${ }^{29} \mathrm{Si} \mathrm{NMR}$ spectrum $\left(\mathrm{C}_{6} \mathrm{D}_{6}\right)$ of $\mathrm{Ni}\left(\mathrm{P}^{\mathrm{Ph}} \mathrm{CNP}^{\mathrm{Ph}}\right)\left(\mathrm{PPh}_{3}\right)\left(\mathrm{Ph}_{2} \mathrm{SiH}_{2}\right) 2[\mathrm{Si}]$.
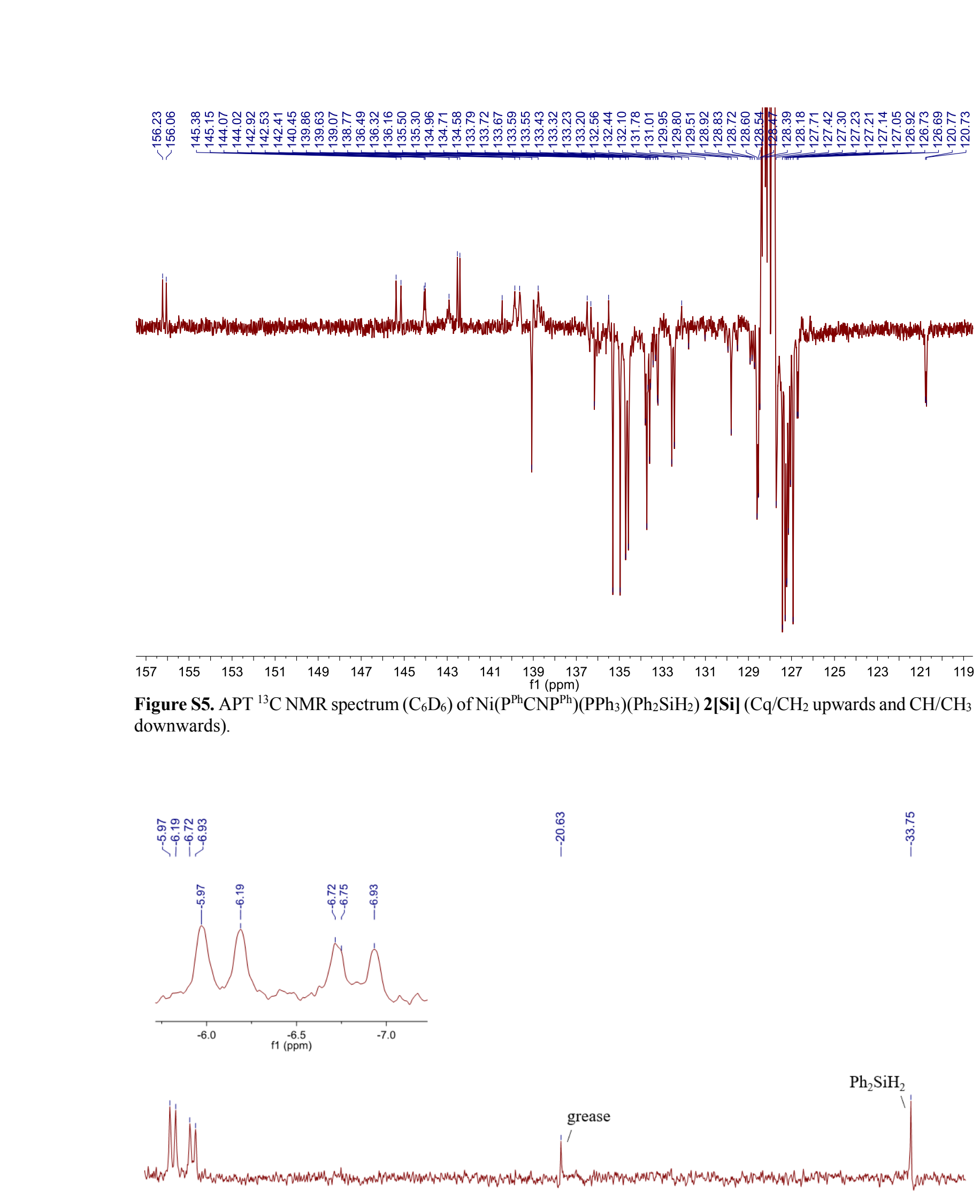

$\stackrel{\sim}{\stackrel{\Gamma}{\oplus}}$

$\mathrm{Ph}_{2} \mathrm{SiH}_{2}$

(1) 


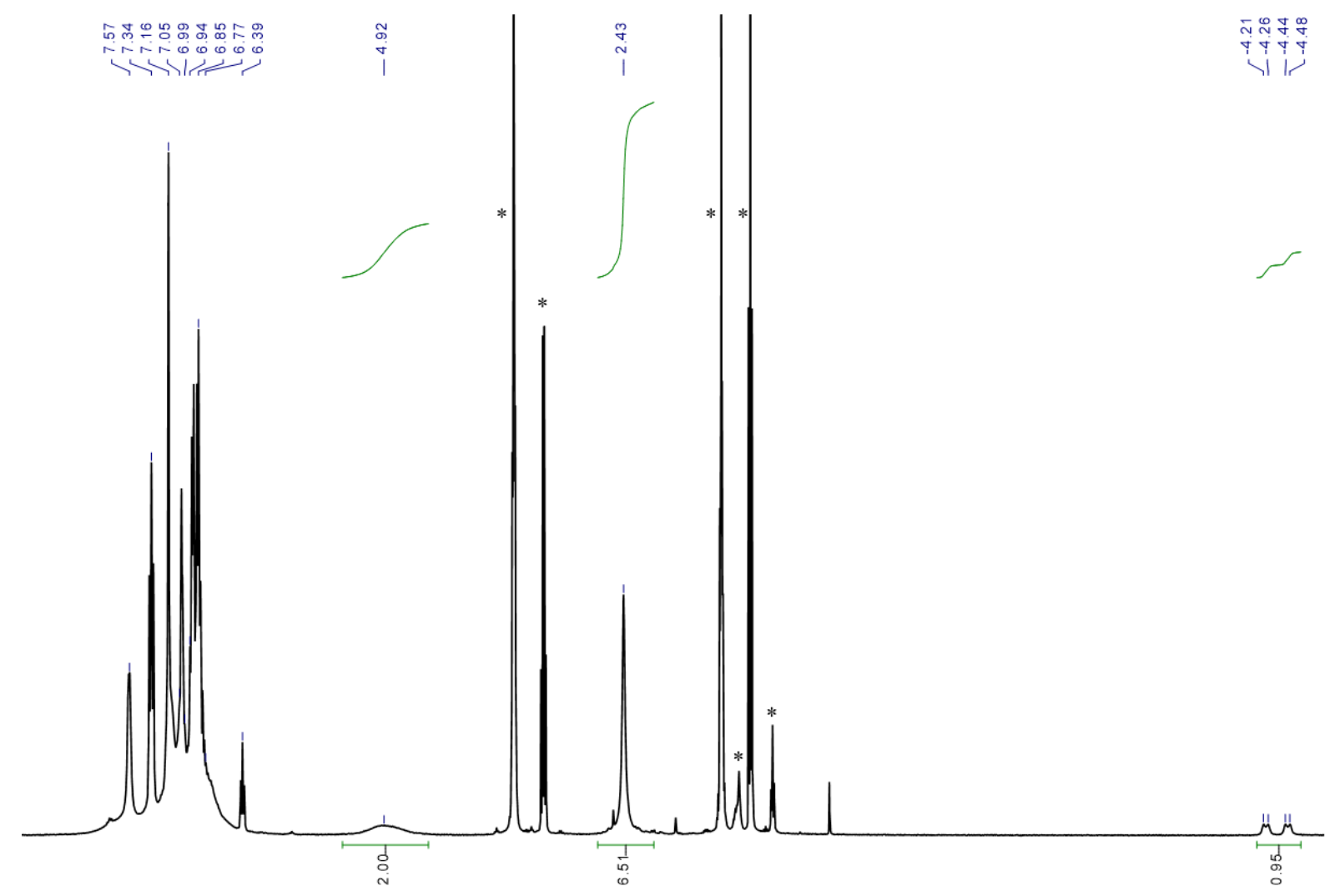

\begin{tabular}{lllllllllllllllllllllllllllllllllllllll}
\hline 8.5 & 8.0 & 7.5 & 7.0 & 6.5 & 6.0 & 5.5 & 5.0 & 4.5 & 4.0 & 3.5 & 3.0 & 2.5 & 2.0 & 1.5 & 1 & 1.0 & 0 & 0 & 0 & 0 & -0.5 & -1.0 & -1.5 & -1.0 & -2.5 & -3.0 & -3.5 & -4.0 & -4.5
\end{tabular}

Figure S7. ${ }^{1} \mathrm{H}$ NMR spectrum $\left(\mathrm{C}_{6} \mathrm{D}_{6}\right)$ of $\mathrm{Ni}\left(\mathrm{P}^{o \mathrm{Tol}} \mathrm{CNP}^{\mathrm{Ph}}\right)\left(\mathrm{PPh}_{3}\right)\left(\mathrm{Ph}_{2} \mathrm{SiH}_{2}\right)$ 3[Si]. The signals marked with * originate from solvents (THF, $\mathrm{Et}_{2} \mathrm{O}$ and hexanes).
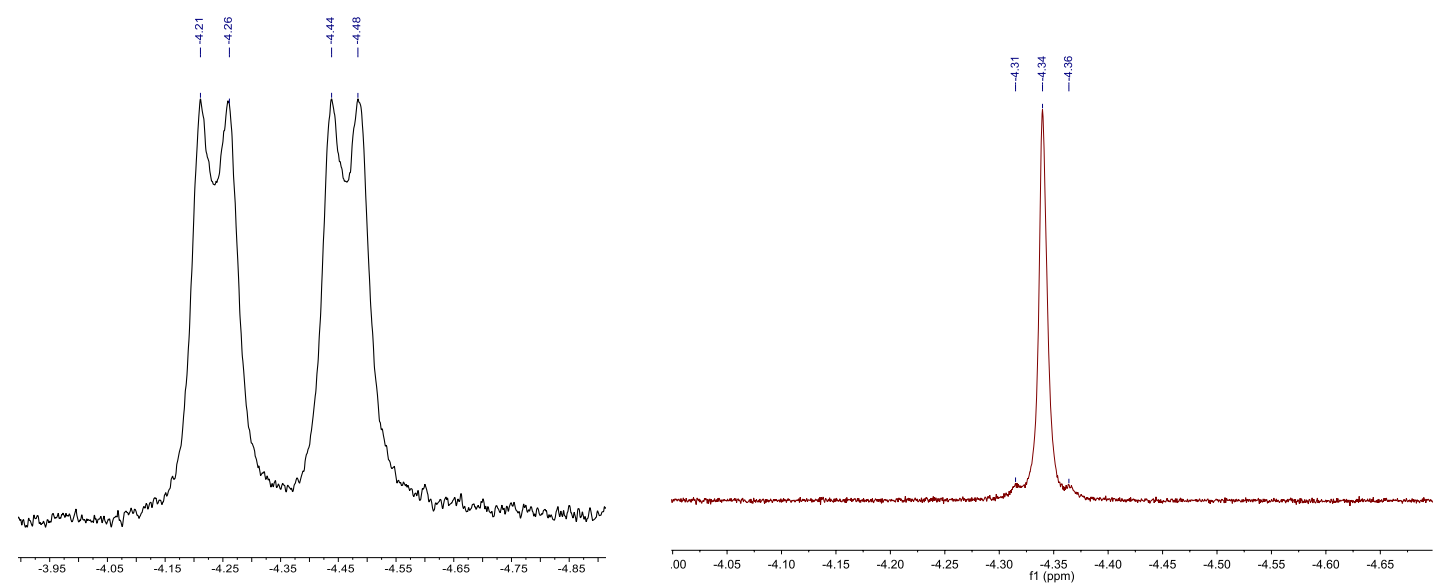

Figure S8. Zoom of the hydride signal in the ${ }^{1} \mathrm{H}$ NMR spectrum $\left(\mathrm{C}_{6} \mathrm{D}_{6}\right)$ of $\mathrm{Ni}\left(\mathrm{P}^{o \mathrm{Tol}} \mathrm{CNP}^{\mathrm{Ph}}\right)\left(\mathrm{PPh}_{3}\right)\left(\mathrm{Ph}_{2} \mathrm{SiH}_{2}\right) 3[\mathrm{Si}]$. left: ${ }^{1} \mathrm{H}$ NMR ${ }^{31} \mathrm{P}$ coupled, right: ${ }^{1} \mathrm{H}$ NMR ${ }^{31} \mathrm{P}$ decoupled. 


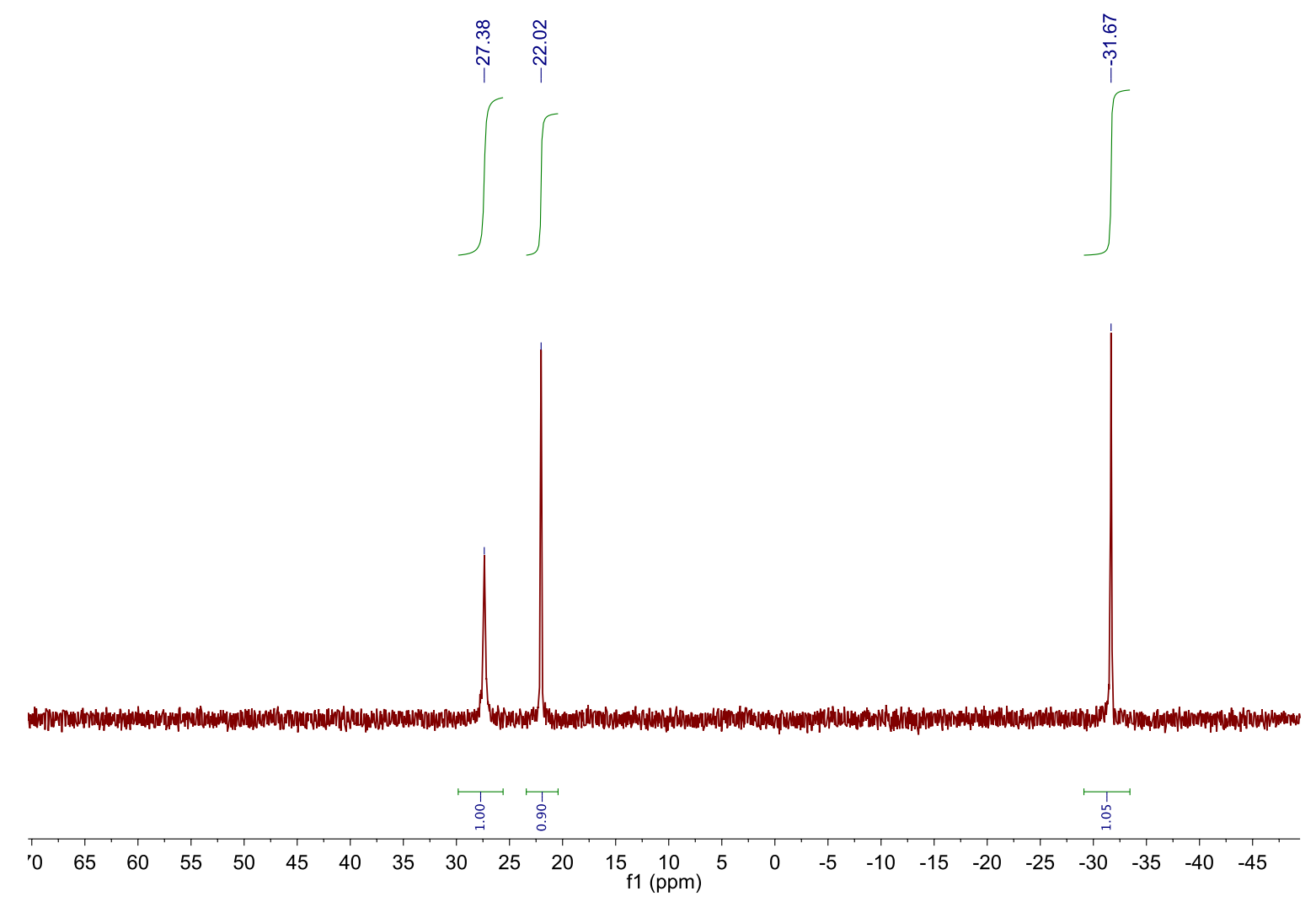

Figure S9. ${ }^{31} \mathrm{P}$ NMR spectrum $\left(\mathrm{C}_{6} \mathrm{D}_{6}\right)$ of $\mathrm{Ni}\left(\mathrm{P}^{o \mathrm{Tol}} \mathrm{CNP}^{\mathrm{Ph}}\right)\left(\mathrm{PPh}_{3}\right)\left(\mathrm{Ph}_{2} \mathrm{SiH}_{2}\right) \mathbf{3}[\mathrm{Si}]$.

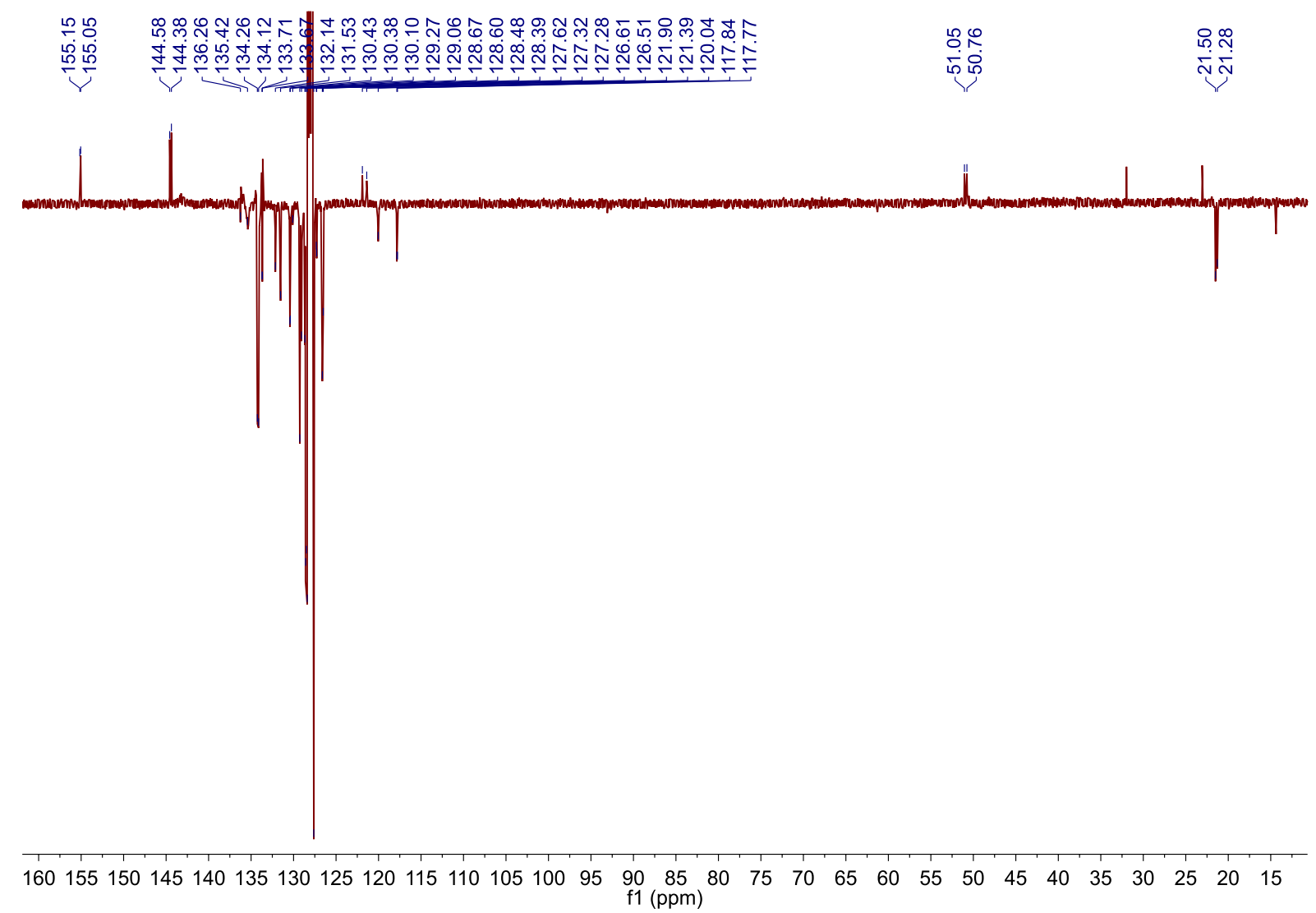

Figure S10. APT ${ }^{13} \mathrm{C}$ NMR spectrum $\left(\mathrm{C}_{6} \mathrm{D}_{6}\right)$ of $\mathrm{Ni}\left(\mathrm{P}^{\circ \mathrm{Tol}} \mathrm{CNP}^{\mathrm{Ph}}\right)\left(\mathrm{PPh}_{3}\right)\left(\mathrm{Ph}_{2} \mathrm{SiH}_{2}\right) 3[\mathrm{Si}]\left(\mathrm{Cq}_{\mathrm{C}} / \mathrm{CH}_{2}\right.$ upwards and $\mathrm{CH} / \mathrm{CH}_{3}$ downwards). 


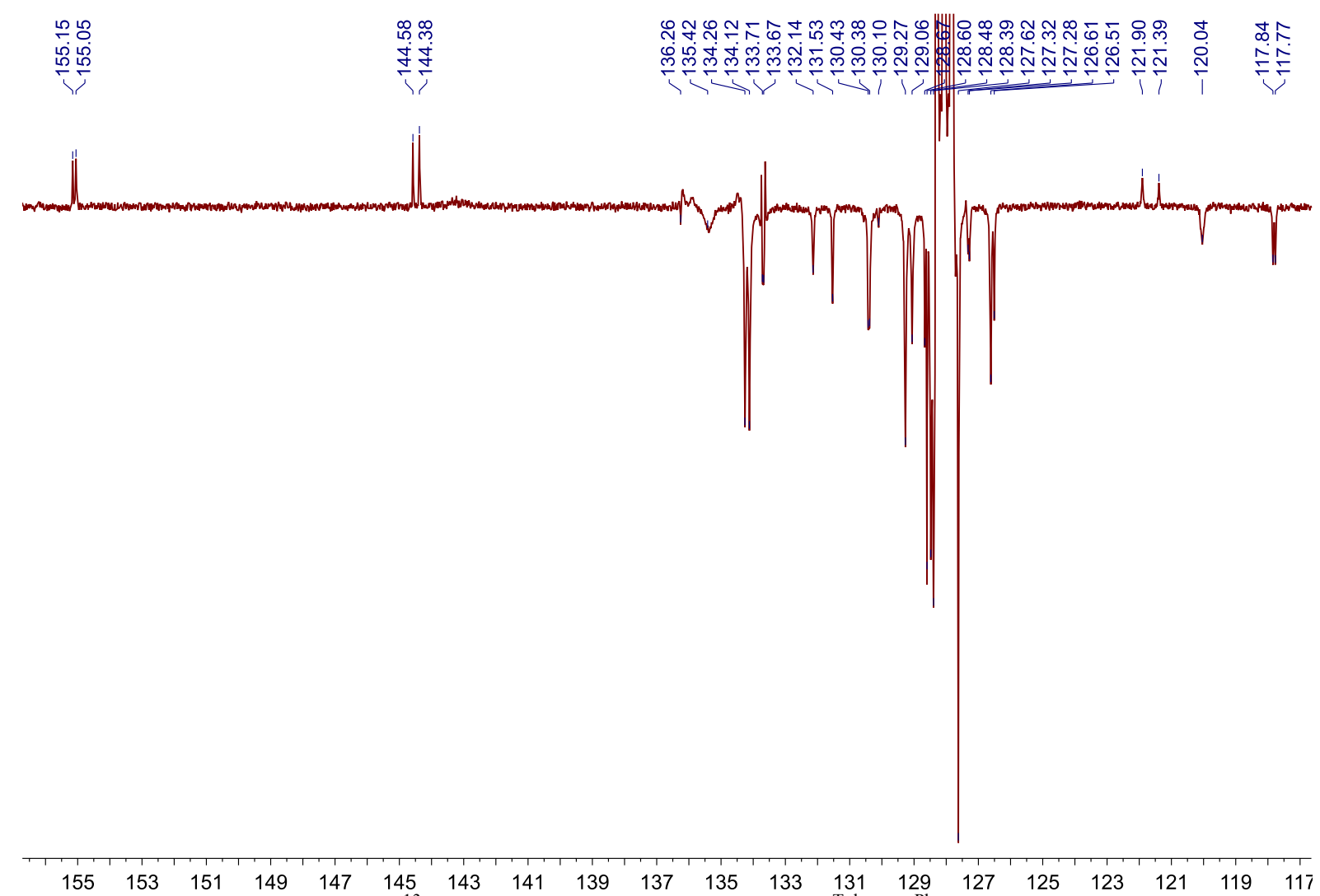

Figure S11. Zoom of the APT ${ }^{13} \mathrm{C}$ NMR spectrum $\left(\mathrm{C}_{6} \mathrm{D}_{6}\right)$ of $\mathrm{Ni}\left(\mathrm{P}^{\text {oTol }} \mathrm{CNP}^{\mathrm{Ph}}\right)\left(\mathrm{PPh}_{3}\right)\left(\mathrm{Ph}_{2} \mathrm{SiH}_{2}\right)$ 3[Si] $\left(\mathrm{Cq}^{2} \mathrm{CH}_{2}\right.$ upwards and $\mathrm{CH} / \mathrm{CH}_{3}$ downwards).

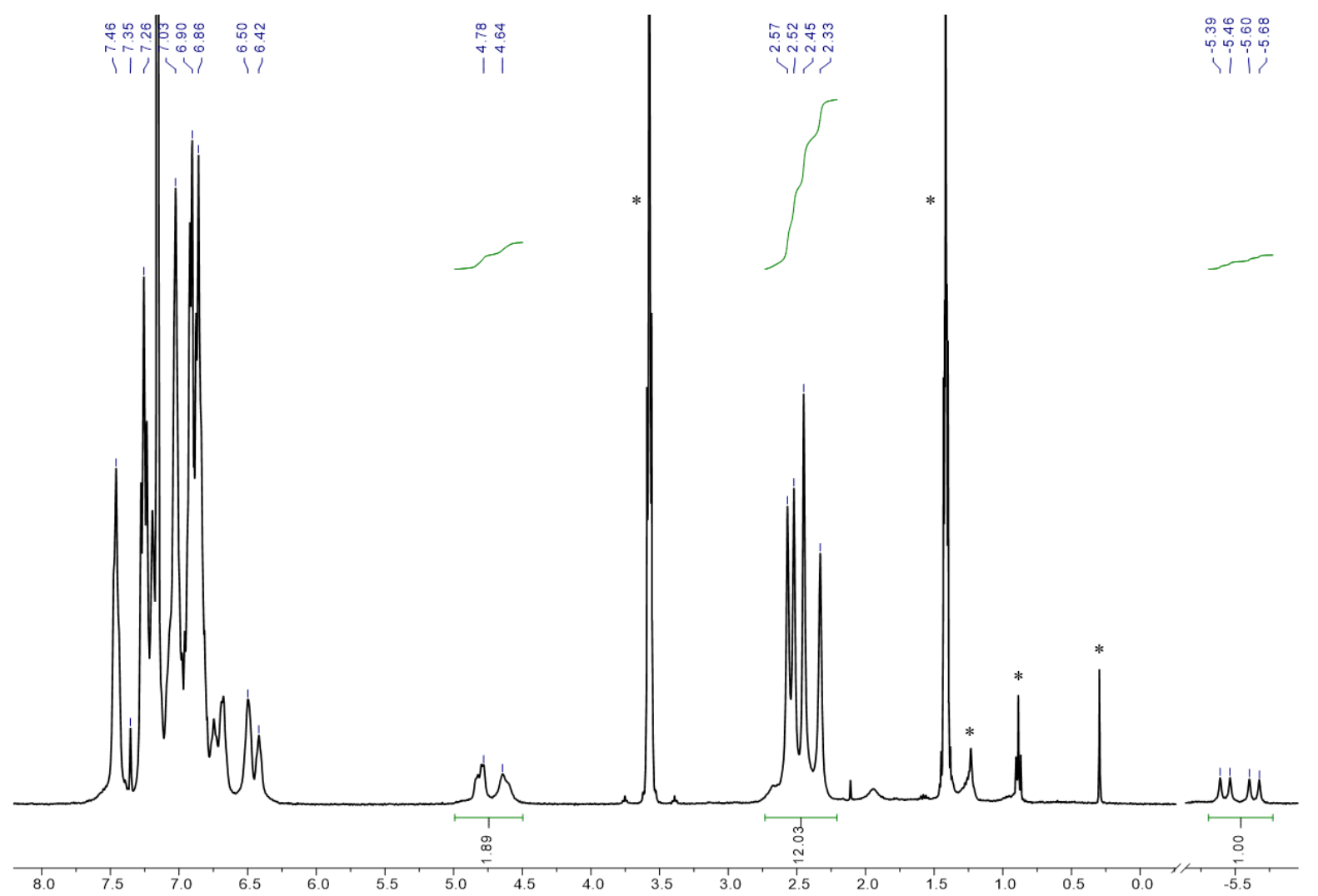

Figure S12. ${ }^{1} \mathrm{H}$ NMR spectrum $\left(\mathrm{C}_{6} \mathrm{D}_{6}\right)$ of $\mathrm{Ni}\left(\mathrm{P}^{o \mathrm{Tol}} \mathrm{CNP}^{o \mathrm{Tol}}\right)\left(\mathrm{PPh}_{3}\right)\left(\mathrm{Ph}_{2} \mathrm{SiH}_{2}\right) 4[\mathrm{Si}]$. The signals marked with * originate from known impurities (THF, hexanes and grease). 


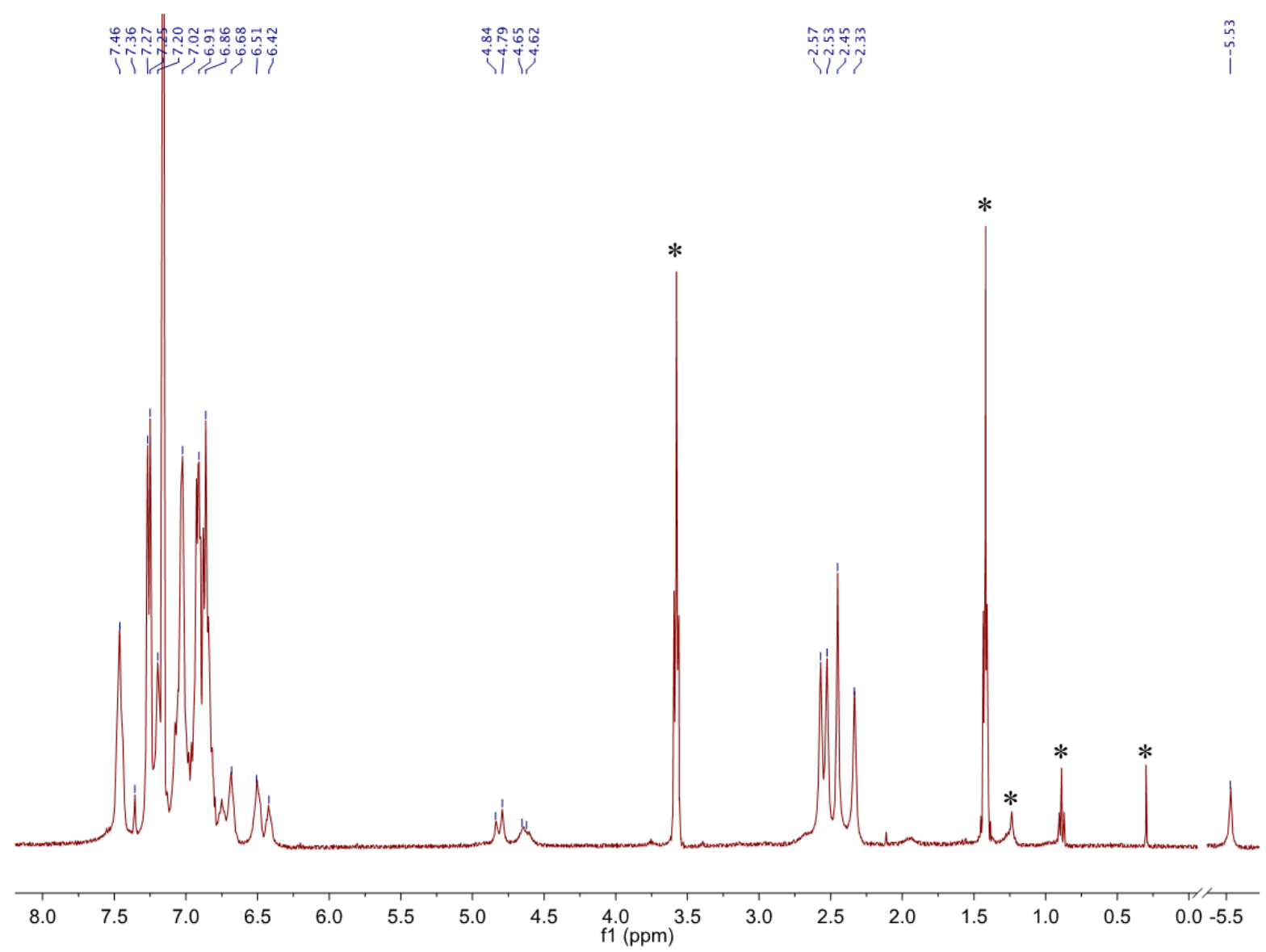

Figure S13. ${ }^{31} \mathrm{P}$ broadband decoupled ${ }^{1} \mathrm{H}$ NMR spectrum $\left(\mathrm{C}_{6} \mathrm{D}_{6}\right)$ of $\mathrm{Ni}\left(\mathrm{P}^{o \mathrm{Tol}} \mathrm{CNP}^{o \mathrm{Tol}}\right)\left(\mathrm{PPh}_{3}\right)\left(\mathrm{Ph}_{2} \mathrm{SiH}_{2}\right) 4[\mathrm{Si}]$. The signals marked with * originate from known impurities (THF, hexanes and grease).

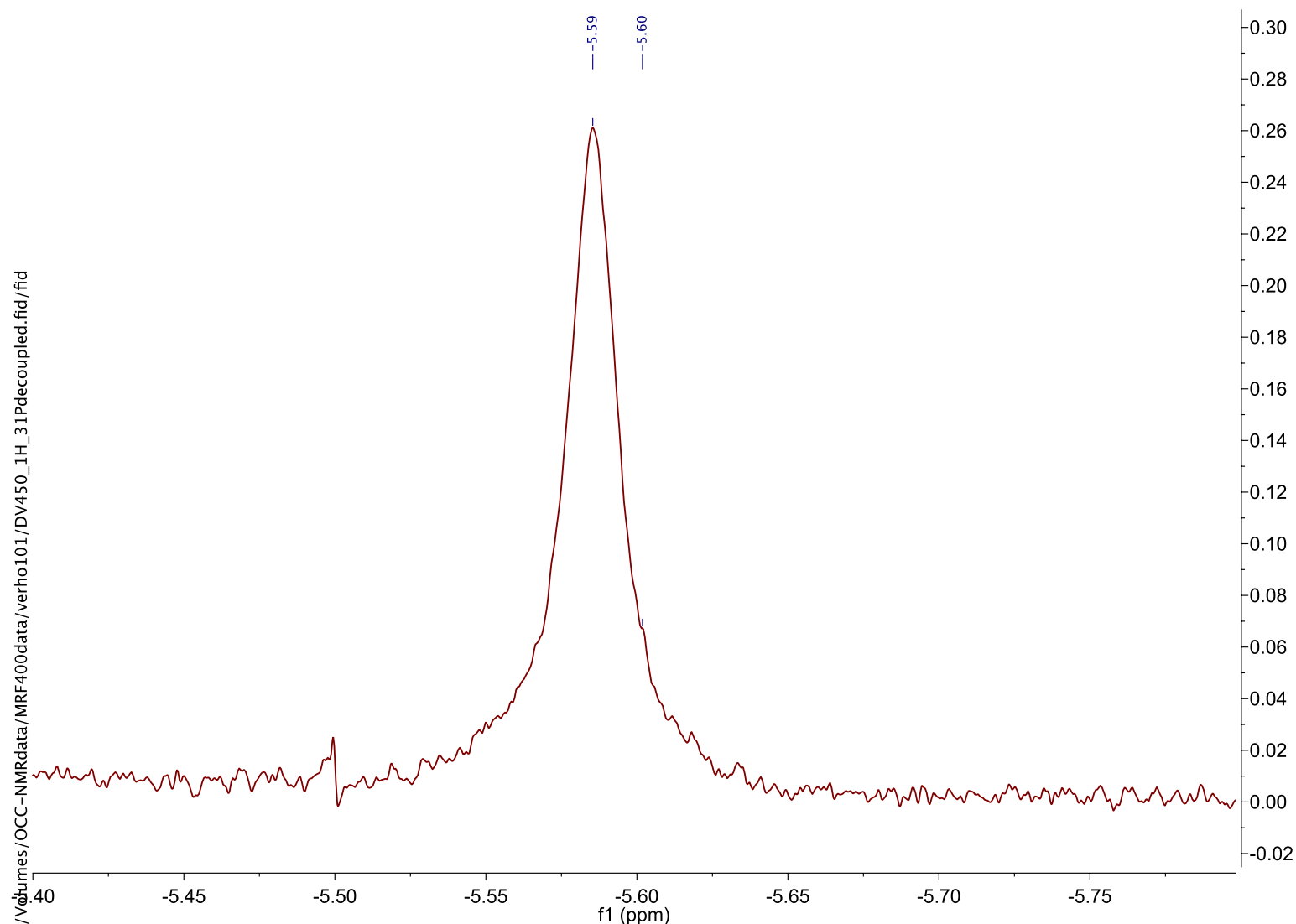

Figure S14. Zoom of the ${ }^{31} \mathrm{P}$ broadband decoupled ${ }^{1} \mathrm{H}$ NMR spectrum $\left(\mathrm{C}_{6} \mathrm{D}_{6}\right)$ of $\mathrm{Ni}\left(\mathrm{P}^{o \mathrm{Tol}} \mathrm{CNP}^{o \mathrm{Tol}}\right)\left(\mathrm{PPh}_{3}\right)\left(\mathrm{Ph}_{2} \mathrm{SiH}_{2}\right)$ 4 [Si]. 


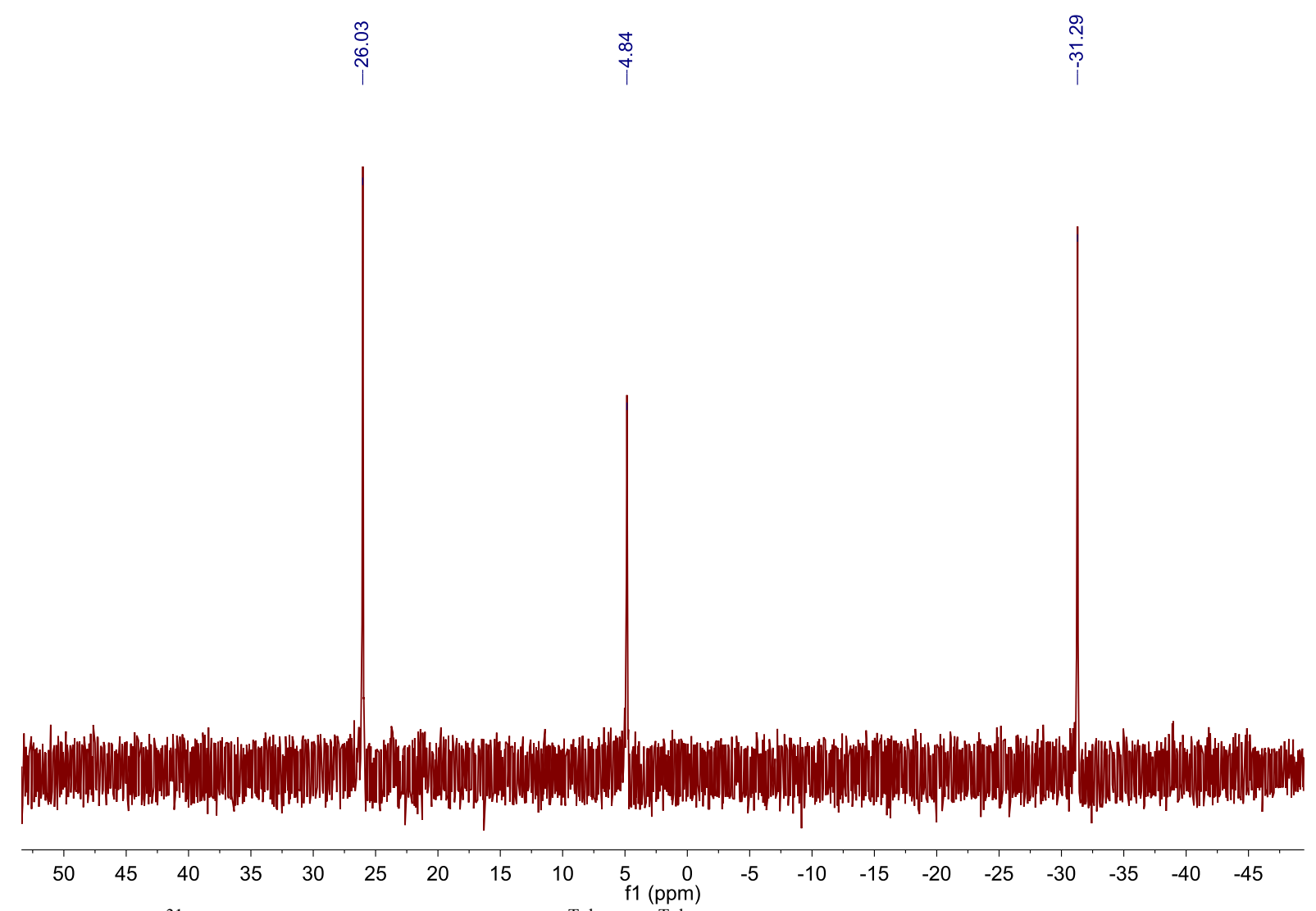

Figure S15. ${ }^{31} \mathrm{P}$ NMR spectrum $\left(\mathrm{C}_{6} \mathrm{D}_{6}\right)$ of $\mathrm{Ni}\left(\mathrm{P}^{o T o l} \mathrm{CNP}^{o T o l}\right)\left(\mathrm{PPh}_{3}\right)\left(\mathrm{Ph}_{2} \mathrm{SiH}_{2}\right) 4[\mathrm{Si}]$.

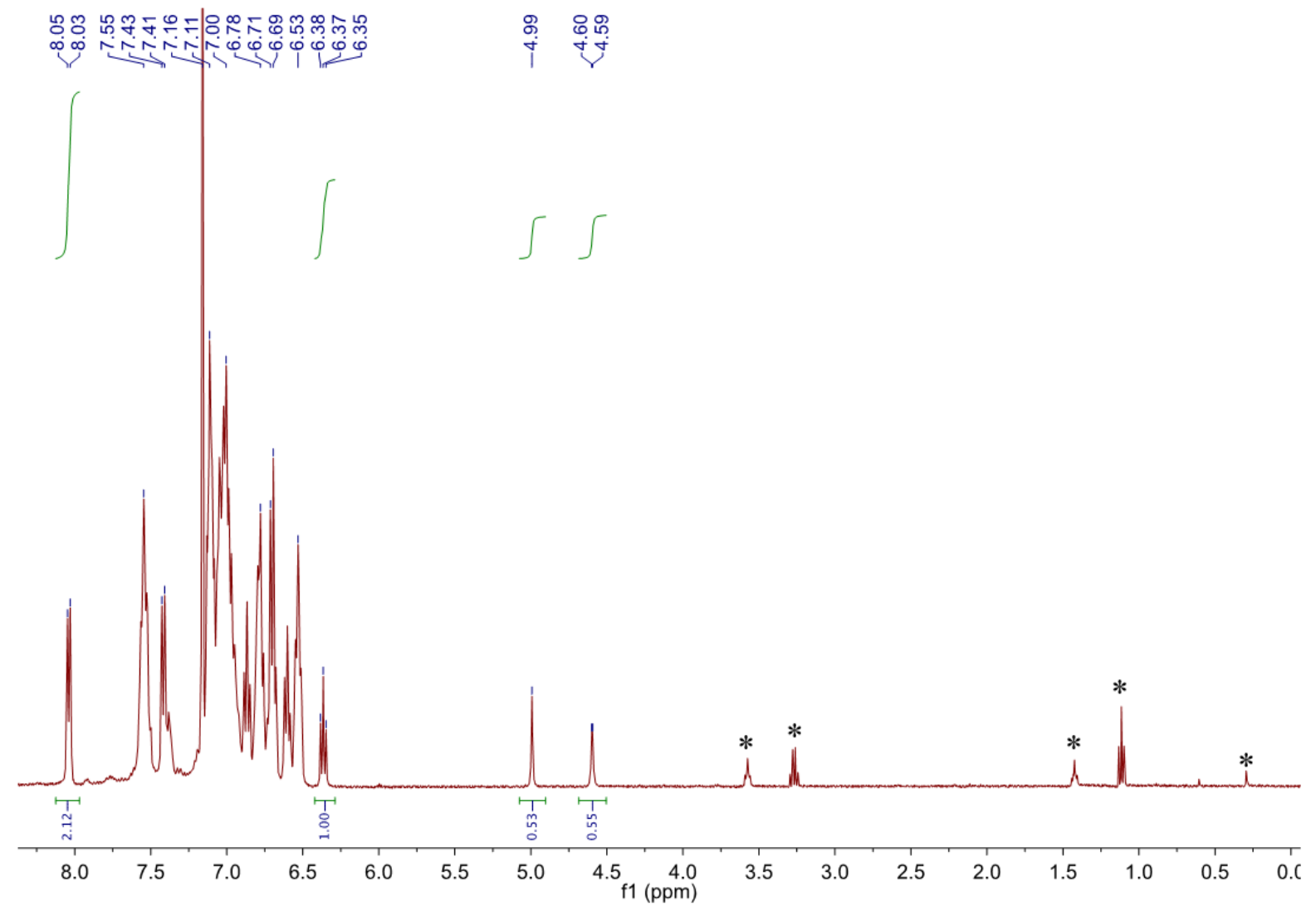

Figure S16. ${ }^{1} \mathrm{H}$ NMR spectrum $\left(\mathrm{C}_{6} \mathrm{D}_{6}\right)$ of $\mathrm{Ni}\left(\mathrm{P}^{\mathrm{Ph}} \mathrm{CNP}^{\mathrm{Ph}}\right)\left(\mathrm{PPh}_{3}\right)\left(\mathrm{Ph}_{2} \mathrm{SiD}_{2}\right)$ 2[SiD $]$. The signals marked with * originate from known impurities ( $\mathrm{THF}, \mathrm{Et}_{2} \mathrm{O}$ and grease). 


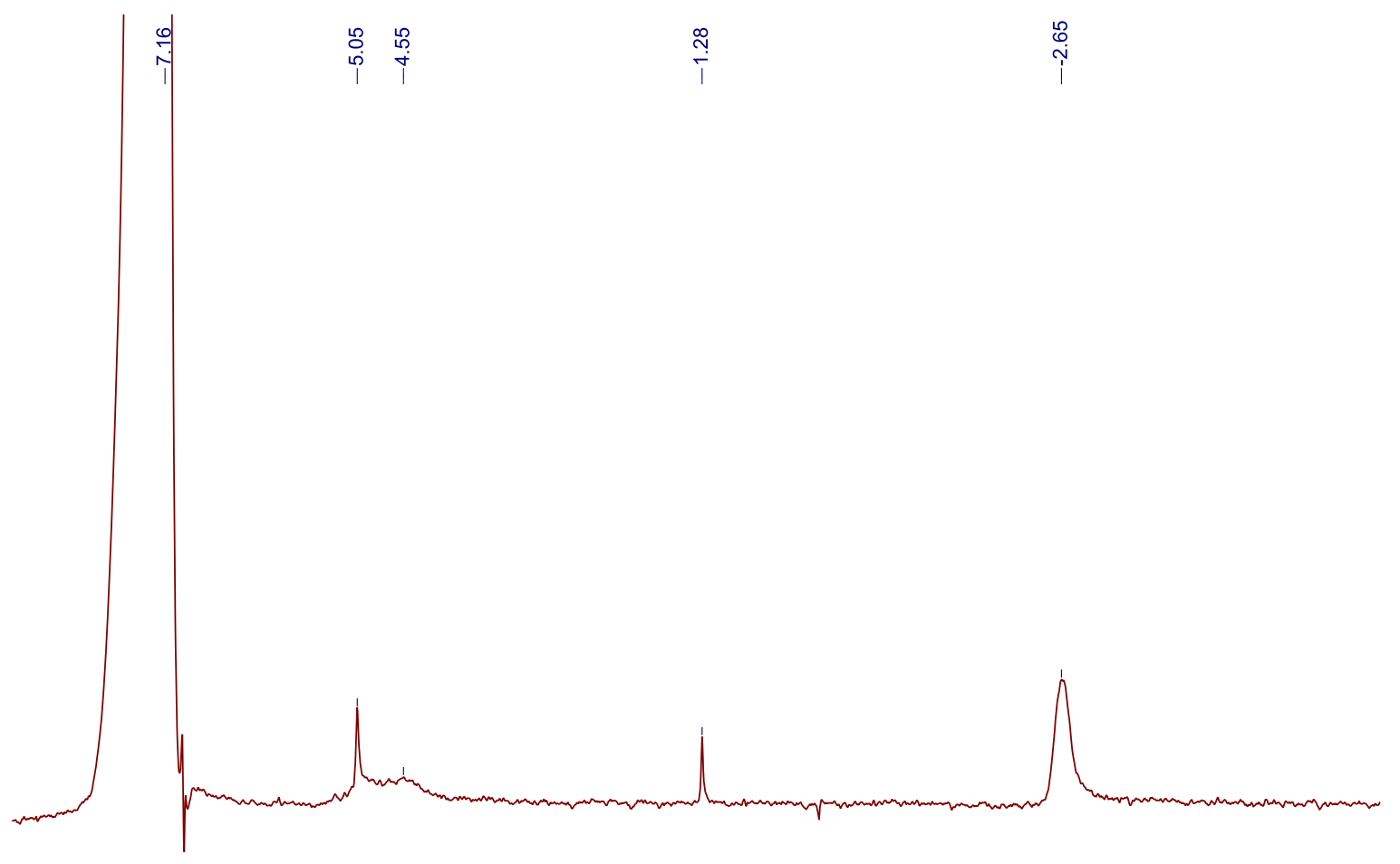

$\begin{array}{llllllllllllllllllllllllllllllllllllllllllll}8.5 & 8.0 & 7.5 & 7.0 & 6.5 & 6.0 & 5.5 & 5.0 & 4.5 & 4.0 & 3.5 & 3.0 & 2.5 & 2.0 & 1.5 & 1.0 & 0.5 & 0.0 & -0.5 & -1.0 & -1.5 & -2.0 & -2.5 & -3.0 & -3.5 & -4.0 & -4.5 & -5.0 & -5.5 & -6 .(\end{array}$

Figure S17. ${ }^{2} \mathrm{H}$ NMR spectrum $\left(\mathrm{C}_{6} \mathrm{D}_{6}\right)$ of $\mathrm{Ni}\left(\mathrm{P}^{\mathrm{Ph}} \mathrm{CNP}^{\mathrm{Ph}}\right)\left(\mathrm{PPh}_{3}\right)\left(\mathrm{Ph}_{2} \mathrm{SiD}_{2}\right){ }_{2}^{2}\left[\mathrm{SiD}_{2}\right]$ with solvent suppression on the $\mathrm{C}_{6} \mathrm{D}_{6}$ signal.

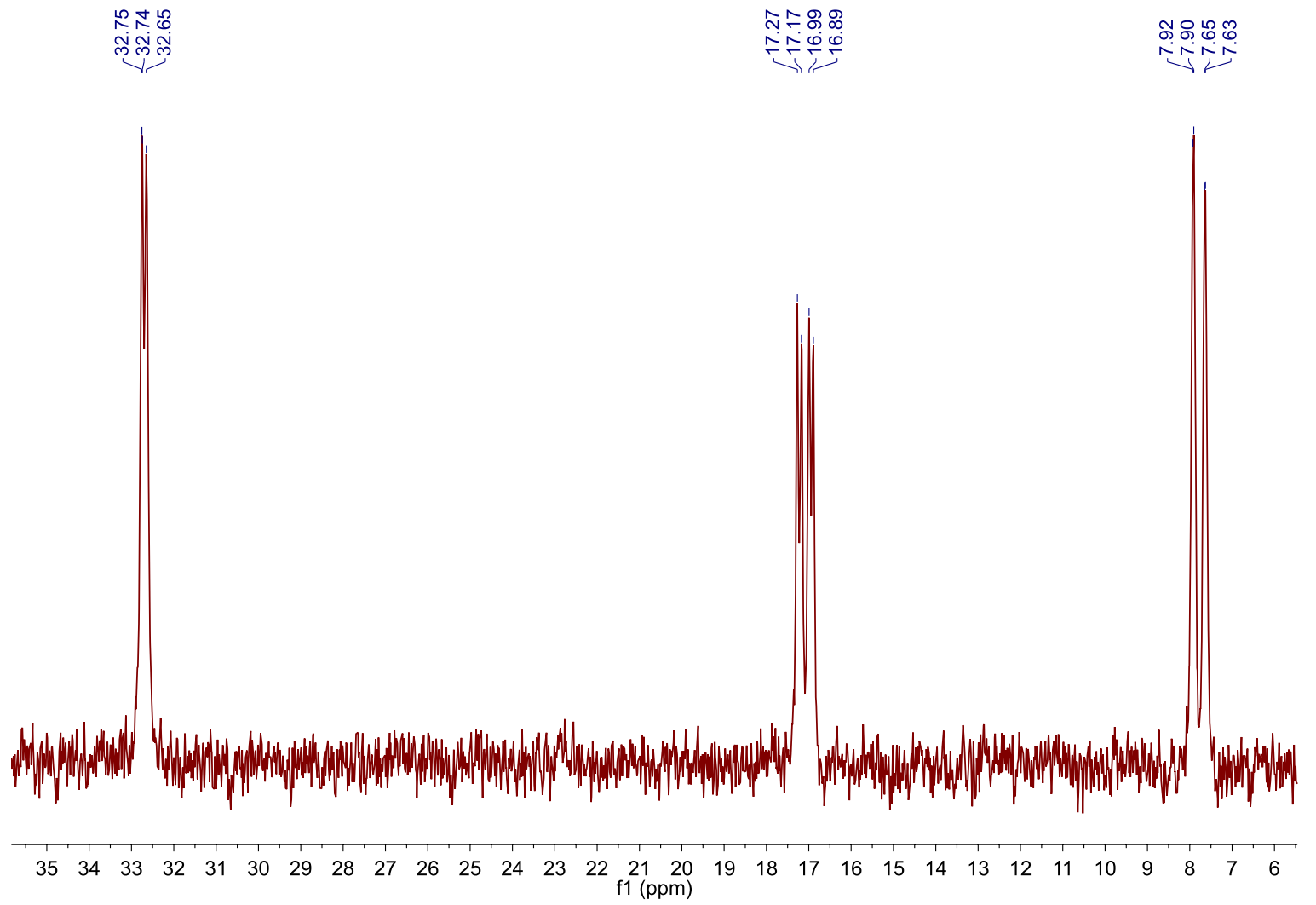

Figure S18. ${ }^{31} \mathrm{P}$ NMR spectrum $\left(\mathrm{C}_{6} \mathrm{D}_{6}\right)$ of $\mathrm{Ni}\left(\mathrm{P}^{\mathrm{Ph}} \mathrm{CNP}^{\mathrm{Ph}}\right)\left(\mathrm{PPh}_{3}\right)\left(\mathrm{Ph}_{2} \mathrm{SiD}_{2}\right) \mathbf{2}\left[\mathrm{SiD}_{2}\right]$. 


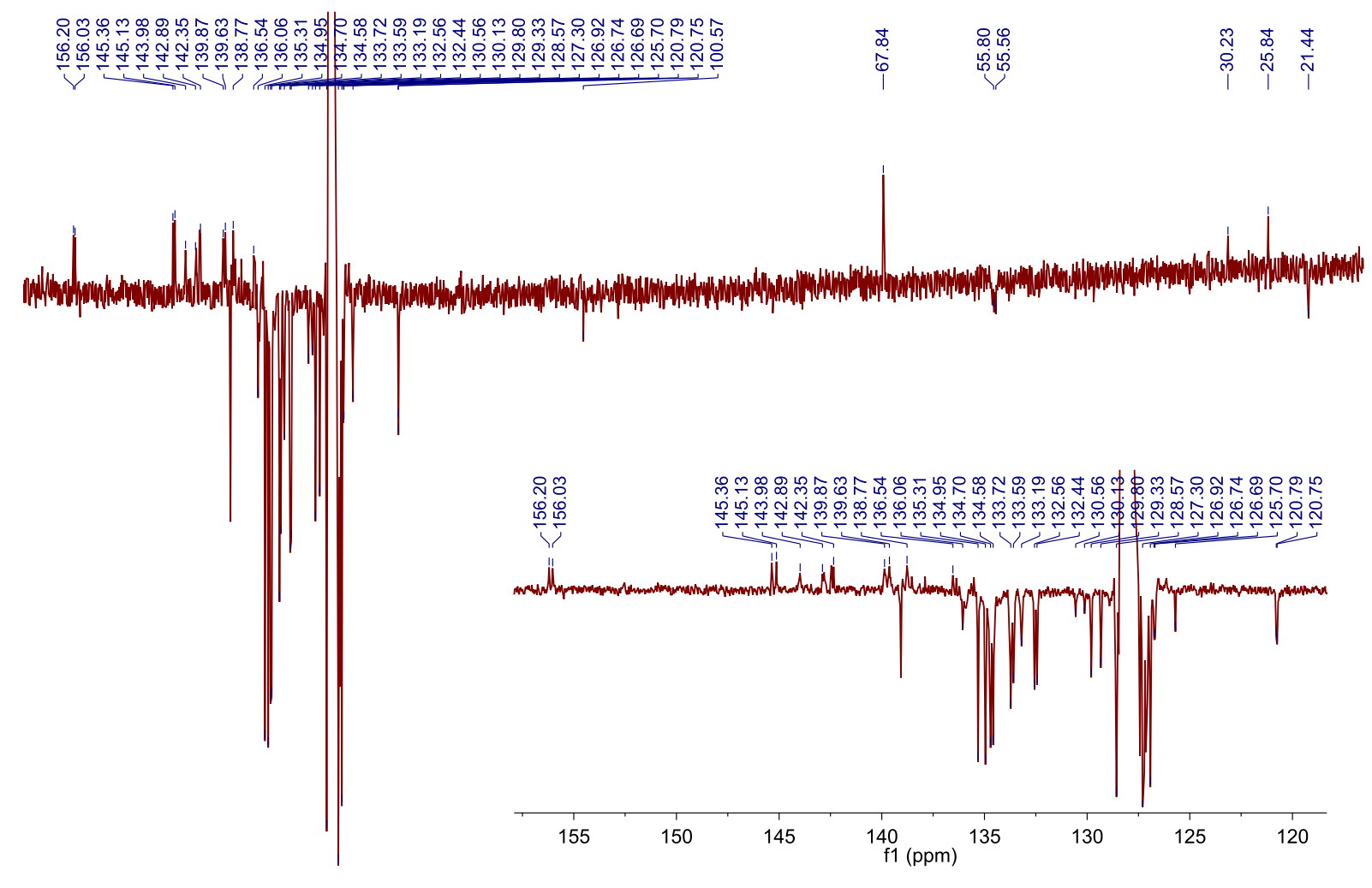

$\begin{array}{lllllllllllllllllllllllllllllll}160 & 155 & 150 & 145 & 140 & 135 & 130 & 125 & 120 & 115 & 110 & 105 & 100 & 95 & 90 & 85 & 80 & 75 & 70 & 65 & 60 & 55 & 50 & 45 & 40 & 35 & 30 & 25 & 20\end{array}$

Figure S19. ${ }^{13} \mathrm{C}$ NMR spectrum $\left(\mathrm{C}_{6} \mathrm{D}_{6}\right)$ of $\mathrm{Ni}\left(\mathrm{P}^{\mathrm{Ph}} \mathrm{CNP}{ }^{\mathrm{Ph}}\right)\left(\mathrm{PPh}_{3}\right)\left(\mathrm{Ph}_{2} \mathrm{SiD}_{2}\right) 2\left[\mathrm{SiD}_{2}\right]$.

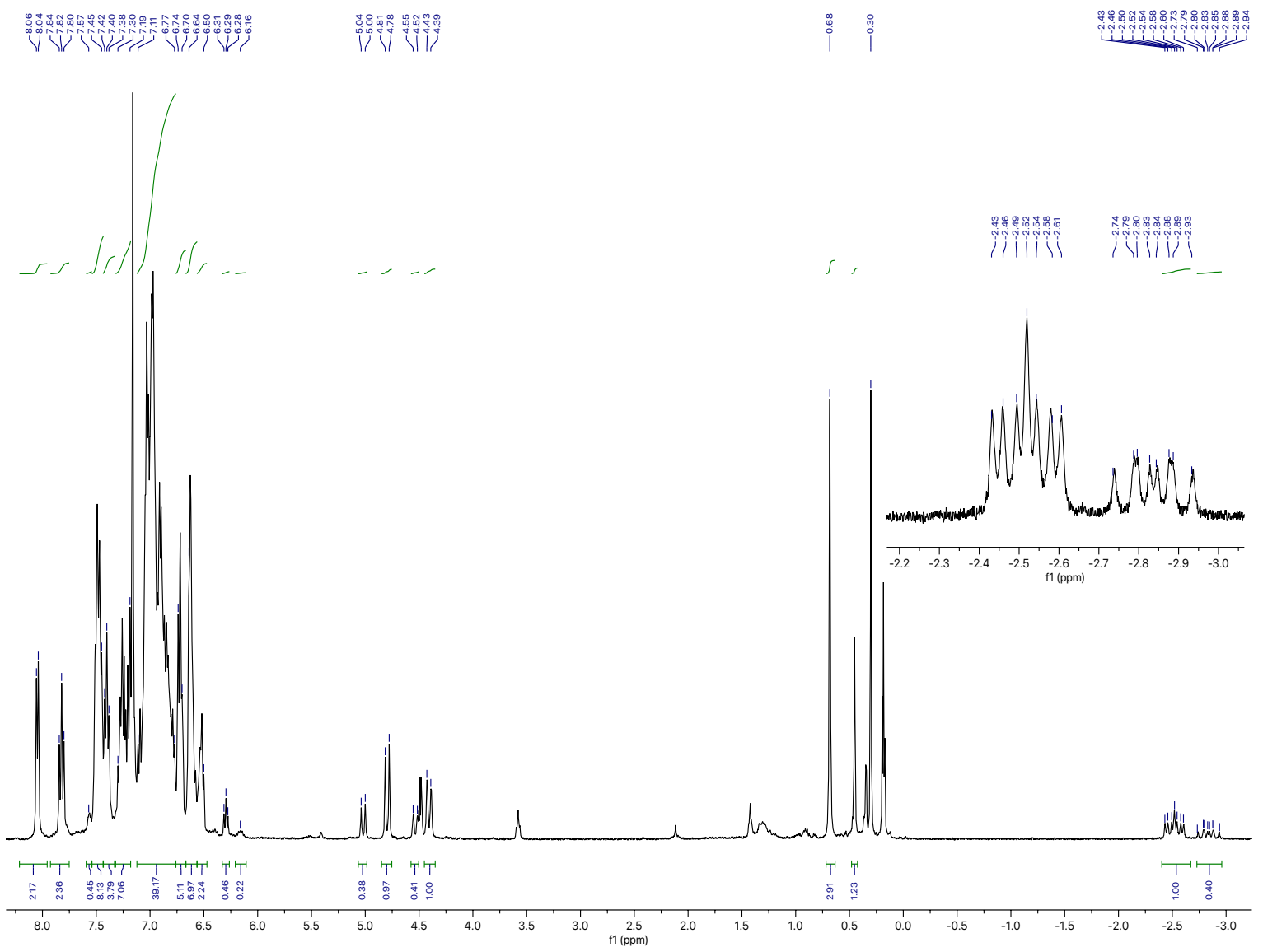

Figure S20. ${ }^{1} \mathrm{H}$ NMR spectrum $\left(\mathrm{C}_{6} \mathrm{D}_{6}\right)$ of $\mathrm{Ni}\left(\mathrm{P}^{\mathrm{Ph}} \mathrm{CNP}^{\mathrm{Ph}}\right)\left(\mathrm{PPh}_{3}\right)\left(\mathrm{PhMeSiH}_{2}\right)$ 2[SiPhMe]. 


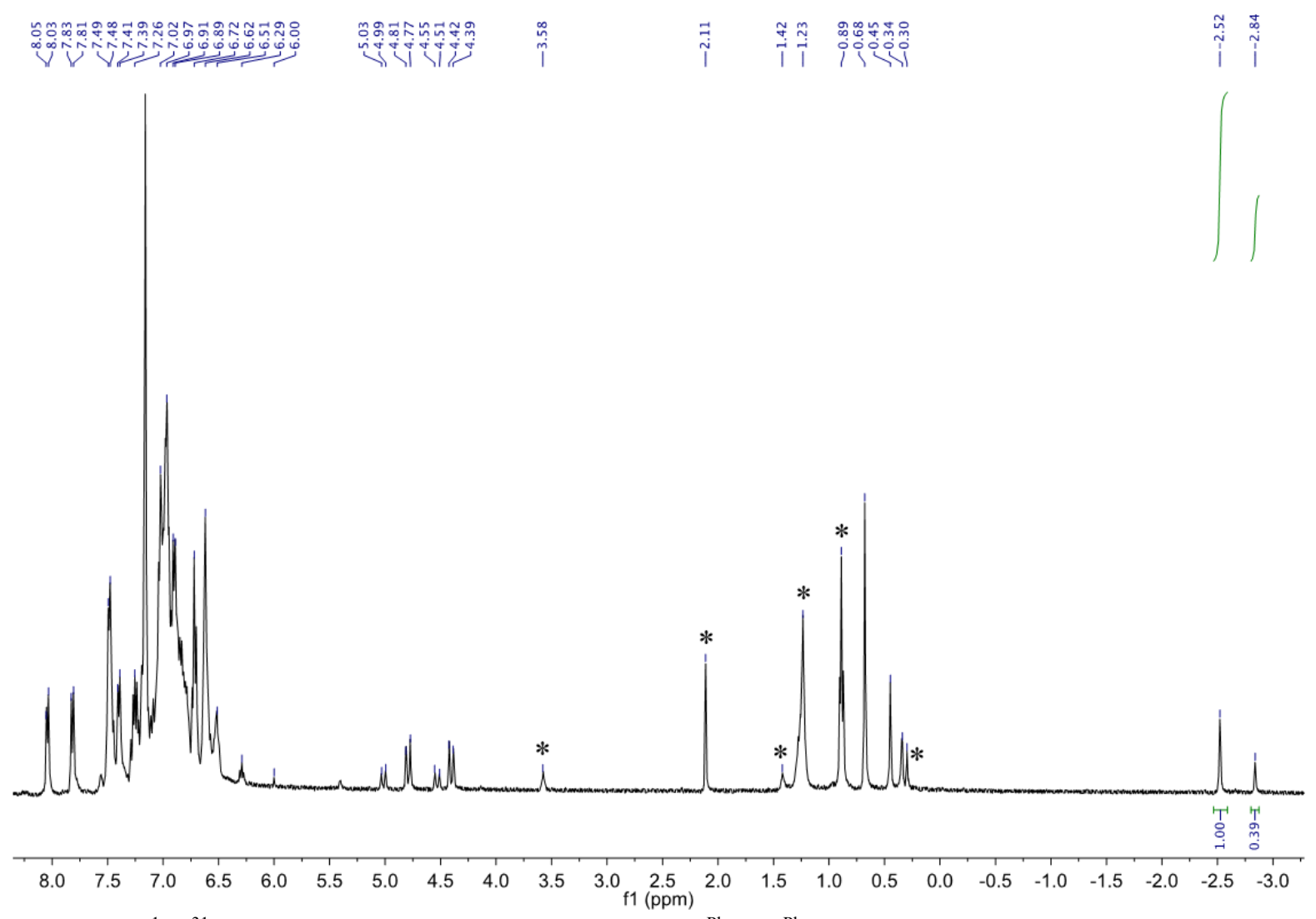

Figure S21. ${ }^{1} \mathrm{H}_{-}{ }^{31} \mathrm{P}$ decoupled NMR spectrum $\left(\mathrm{C}_{6} \mathrm{D}_{6}\right)$ of $\mathrm{Ni}\left(\mathrm{P}^{\mathrm{Ph}} \mathrm{CNP}^{\mathrm{Ph}}\right)\left(\mathrm{PPh}_{3}\right)\left(\mathrm{PhMeSiH}_{2}\right)$ 2[SiPhMe]. The signals marked with * originate from known impurities (THF, toluene, hexanes and grease).

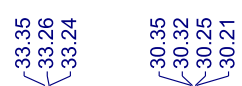
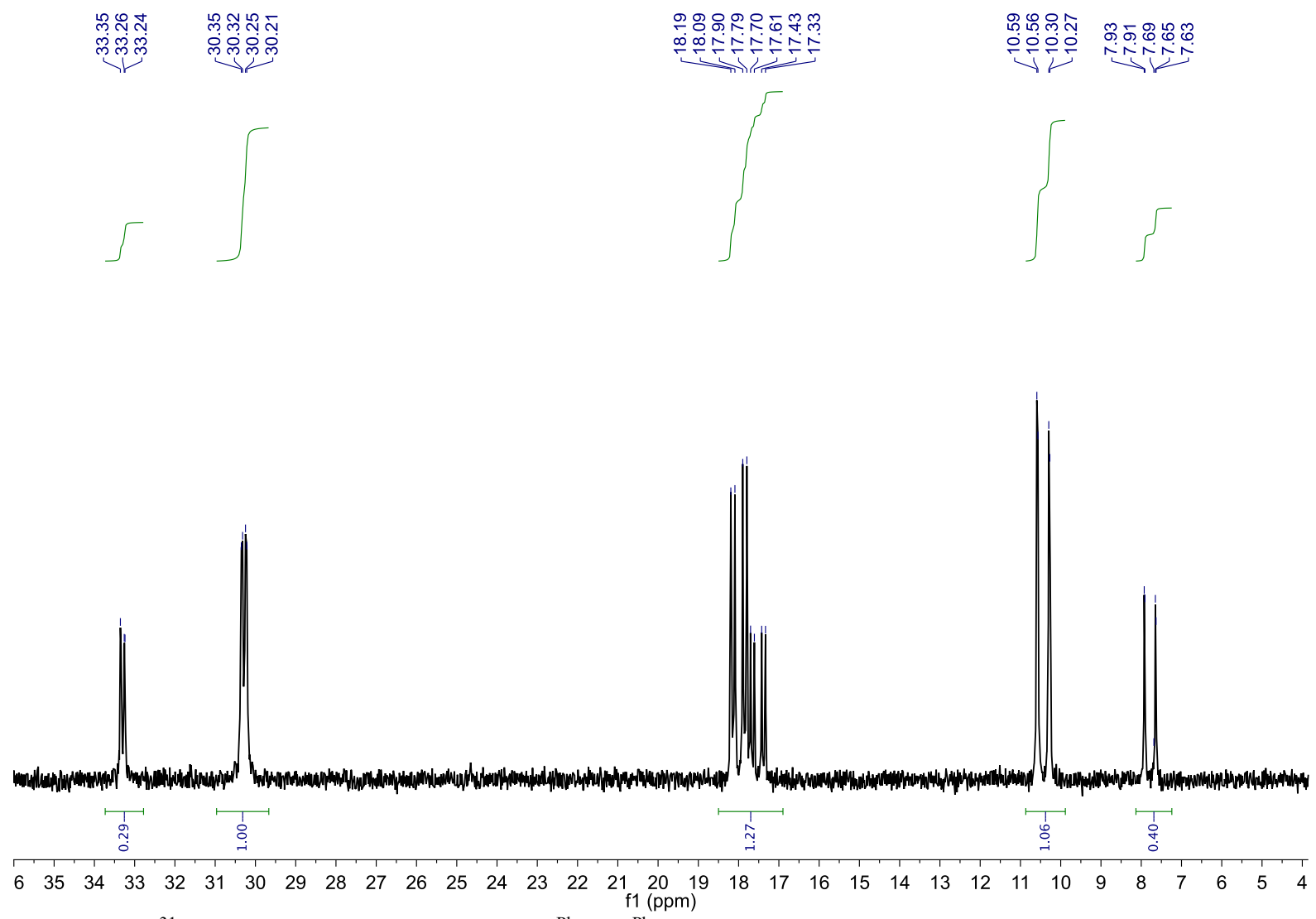

Figure S22. ${ }^{31} \mathrm{P}$ NMR spectrum $\left(\mathrm{C}_{6} \mathrm{D}_{6}\right)$ of $\mathrm{Ni}\left(\mathrm{P}^{\mathrm{Ph}} \mathrm{CNP}^{\mathrm{Ph}}\right)\left(\mathrm{PPh}_{3}\right)\left(\mathrm{PhMeSiH}_{2}\right) 2$ [SiPhMe]. 


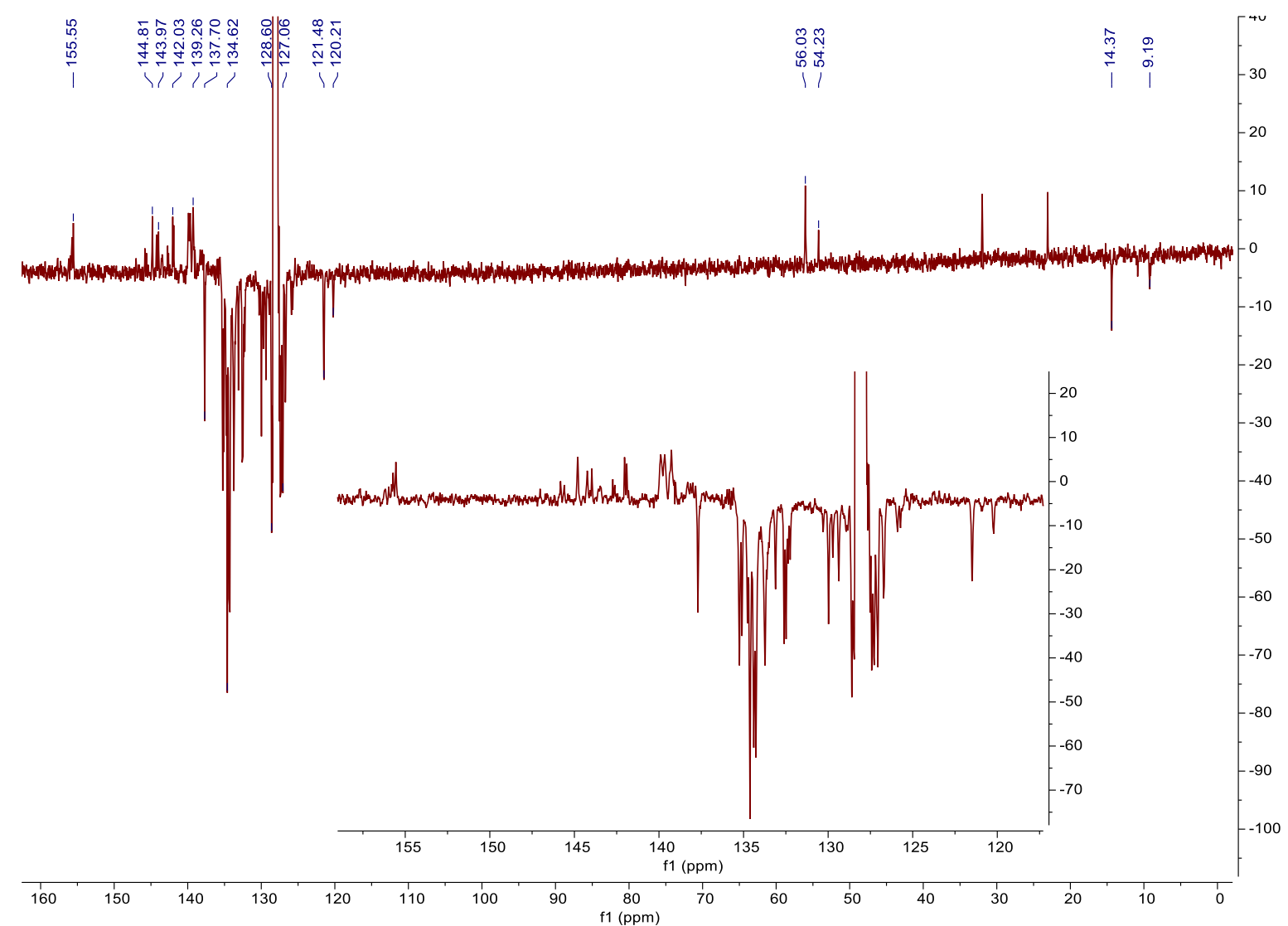

Figure S23. APT ${ }^{13} \mathrm{C}$ NMR spectrum $\left(\mathrm{C}_{6} \mathrm{D}_{6}\right)$ of $\mathrm{Ni}\left(\mathrm{P}^{\mathrm{Ph}} \mathrm{CNP}^{\mathrm{Ph}}\right)\left(\mathrm{PPh}_{3}\right)\left(\mathrm{PhMeSiH}_{2}\right)$ 2[SiPhMe] $\left(\mathrm{Cq} / \mathrm{CH}_{2}\right.$ upwards and $\mathrm{CH} / \mathrm{CH}_{3}$ downwards).

$$
\text { ن̂. }
$$
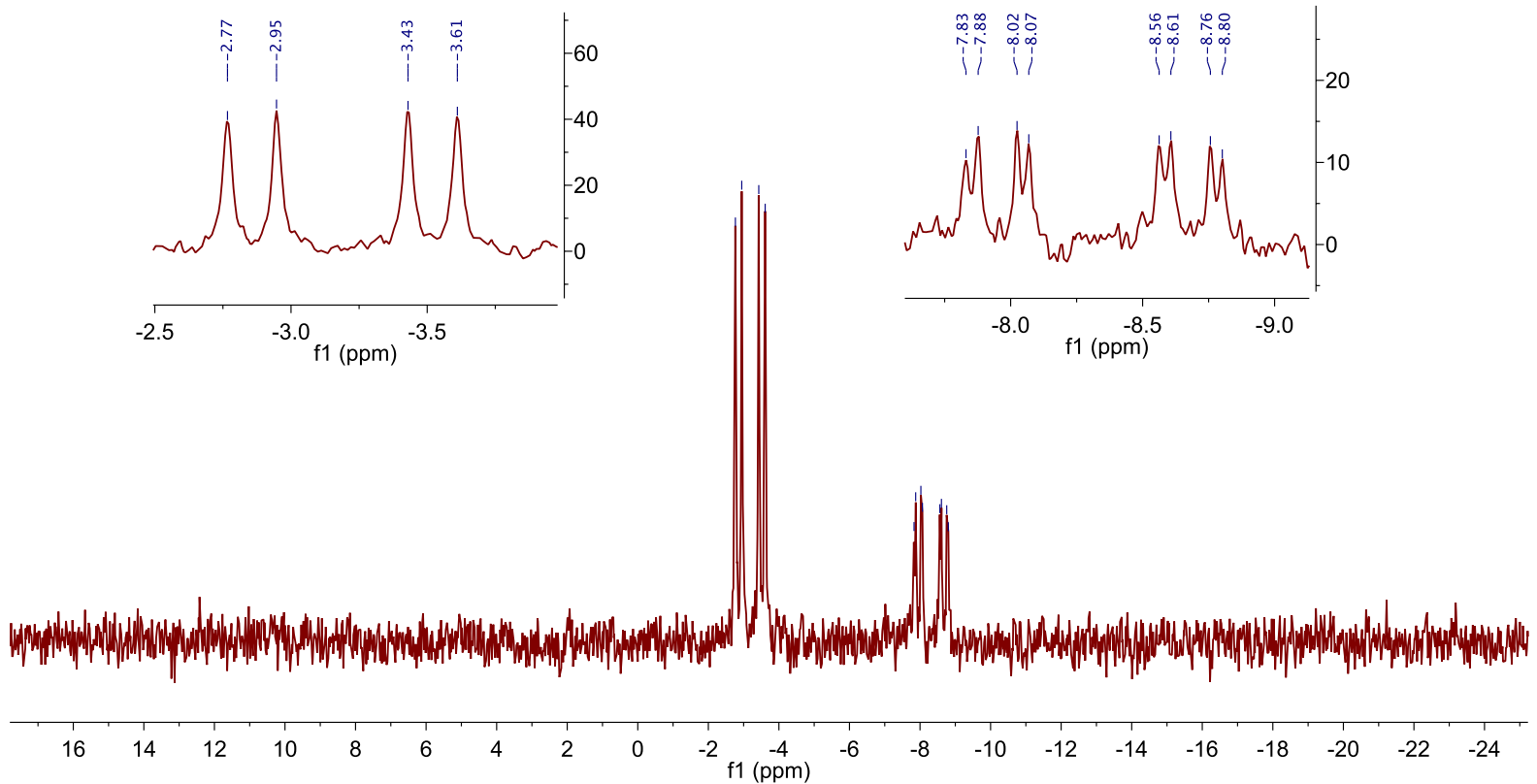

Figure S24. ${ }^{29} \mathrm{Si} \mathrm{NMR}$ spectrum $\left(\mathrm{C}_{6} \mathrm{D}_{6}\right)$ of $\mathrm{Ni}\left(\mathrm{P}^{\mathrm{Ph}} \mathrm{CNP}^{\mathrm{Ph}}\right)\left(\mathrm{PPh}_{3}\right)\left(\mathrm{PhMeSiH}_{2}\right) 2$ [SiPhMe]. 


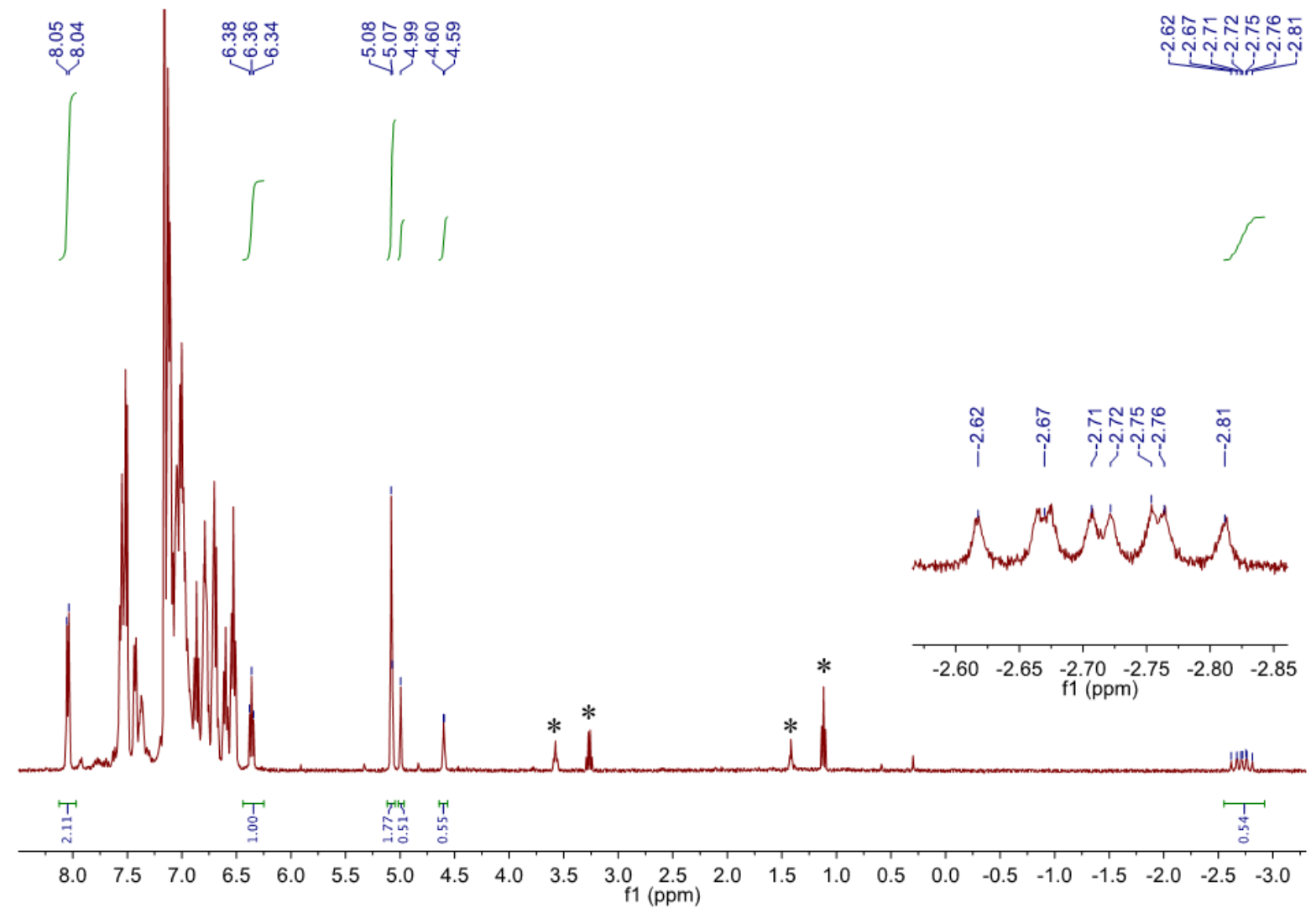

Figure S25. ${ }^{1} \mathrm{H}$ NMR spectrum $\left(\mathrm{C}_{6} \mathrm{D}_{6}\right)$ of $2\left[\mathbf{S i D}_{2}\right]+\mathrm{Ph}_{2} \mathrm{SiH}_{2}$ scrambling experiment (time $\left.=2 \mathrm{~h}\right)$. The signals marked with * originate from known impurities (THF and $\mathrm{Et}_{2} \mathrm{O}$ ). 
3. IR spectra

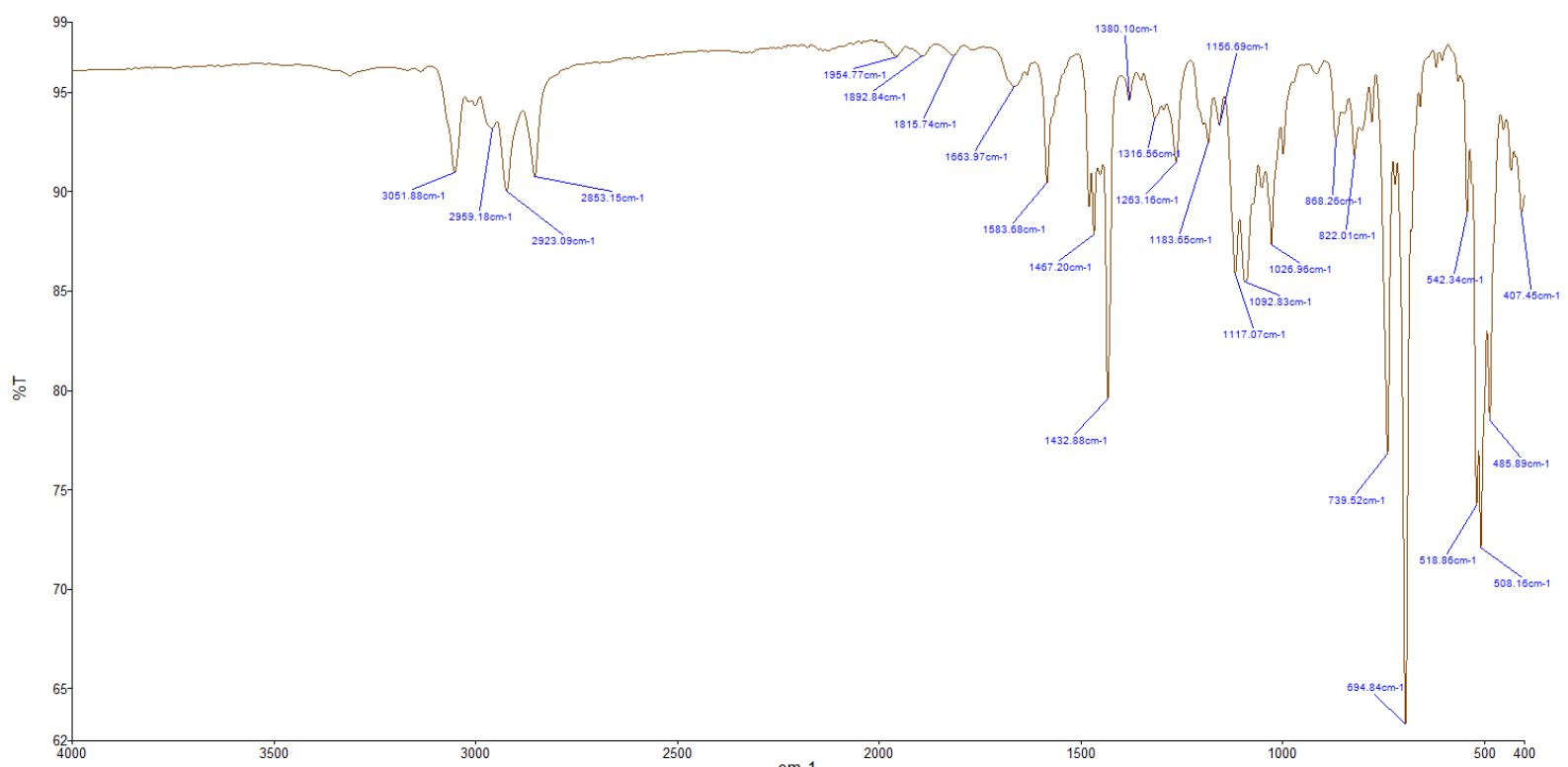

Figure S26. ATR-IR spectrum of $\left(\mathrm{P}^{\mathrm{Ph}} \mathrm{CNP}^{\mathrm{Ph}}\right)\left(\mathrm{PPh}_{3}\right)\left(\mathrm{Ph}_{2} \mathrm{SiH}_{2}\right) 2$ 2[Si].

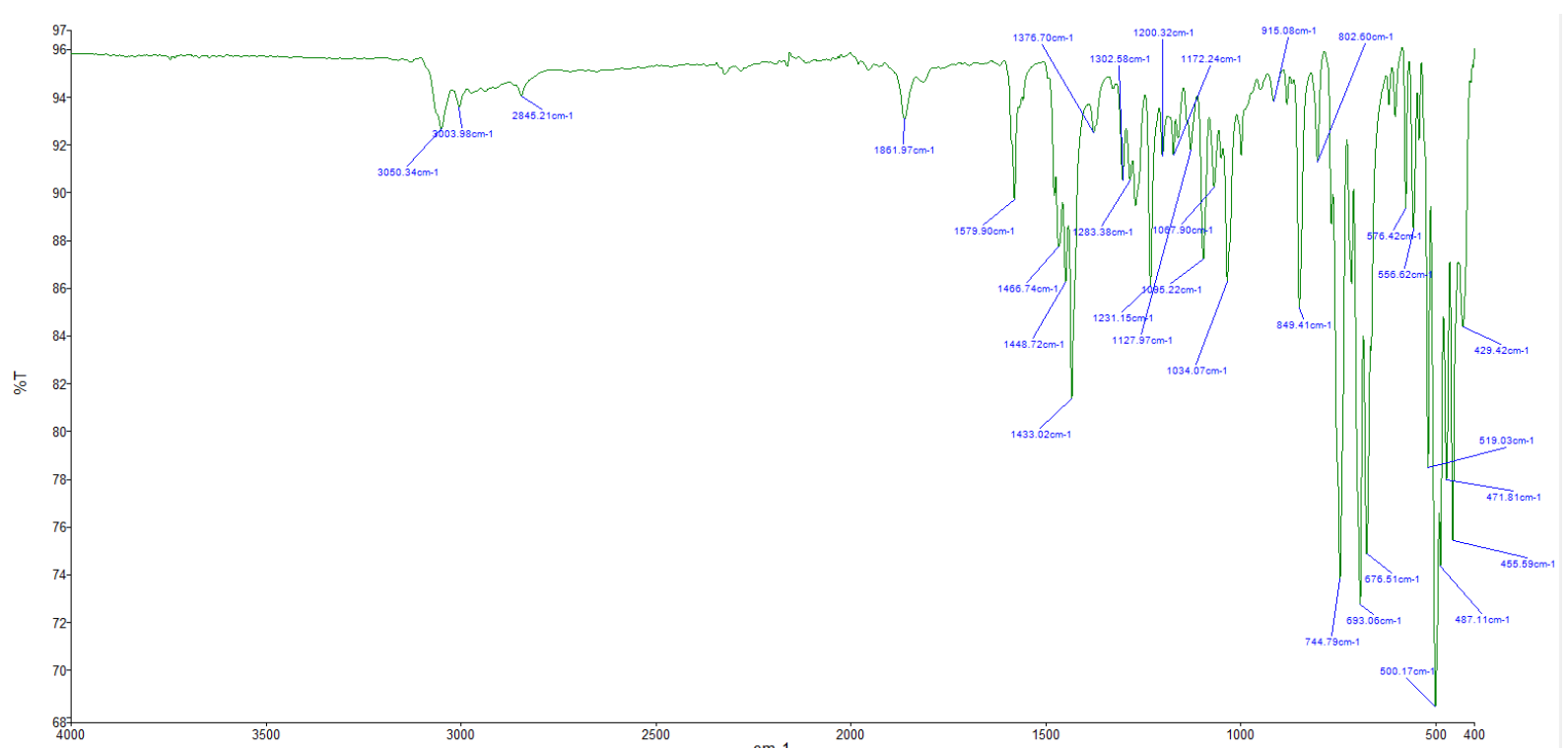

Figure S27. ATR-IR spectrum of $\left(\mathrm{P}^{o \text { Tol }} \mathrm{CNP}^{\circ \mathrm{Tol}}\right)\left(\mathrm{PPh}_{3}\right)\left(\mathrm{Ph}_{2} \mathrm{SiH}_{2}\right) 4[\mathrm{Si}]$. 


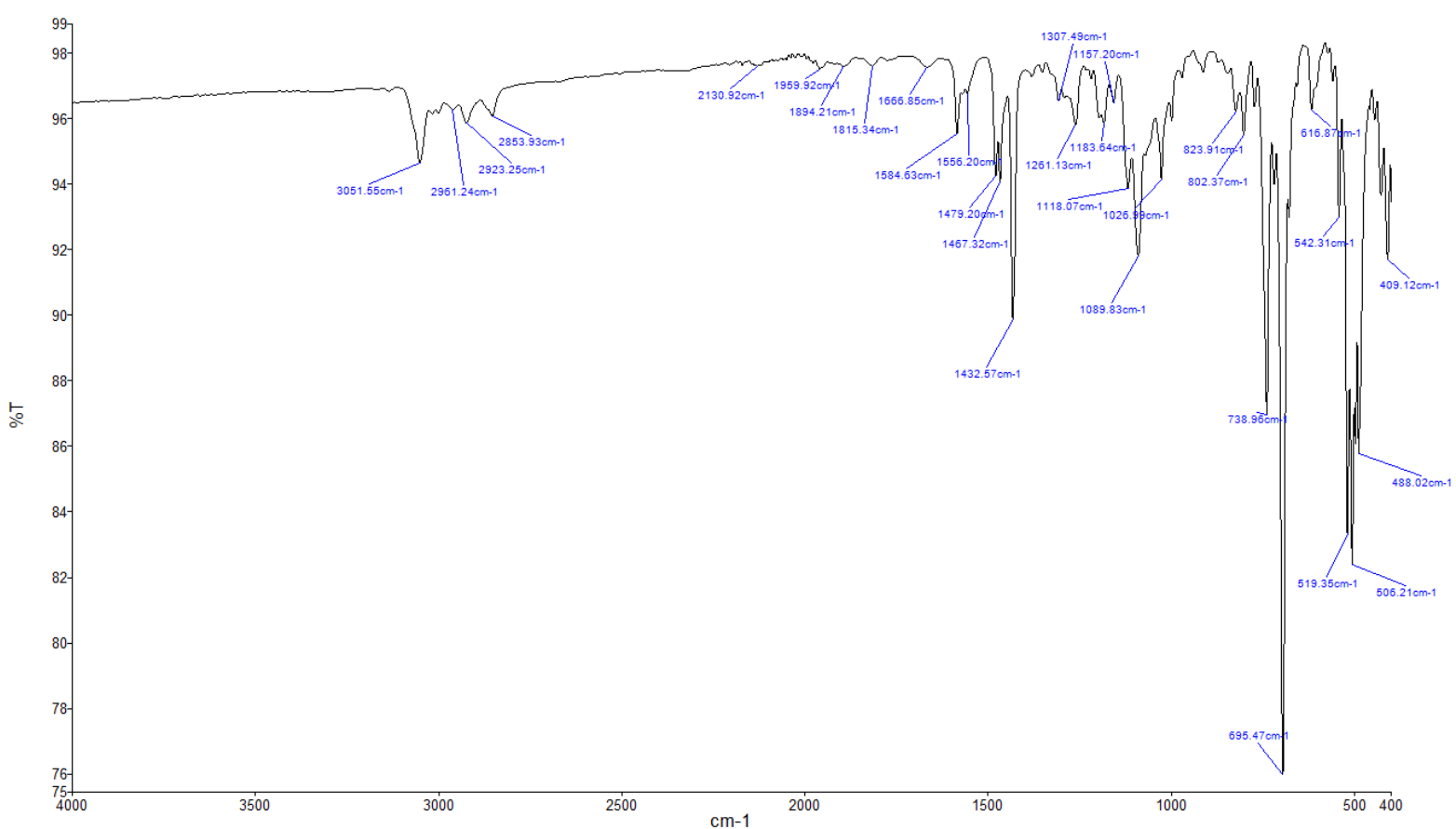

Figure S28. ATR-IR spectrum of $\mathrm{Ni}\left(\mathrm{P}^{\mathrm{Ph}} \mathrm{CNP} \mathrm{Ph}^{\mathrm{Ph}}\right)\left(\mathrm{PPh}_{3}\right)\left(\mathrm{Ph}_{2} \mathrm{SiD}_{2}\right) 2\left[\mathrm{SiD}_{2}\right]$. 


\section{X-ray crystallographic data}

3[Si]: $\mathrm{C}_{69} \mathrm{H}_{60} \mathrm{NNiP}_{3} \mathrm{Si} \cdot 0.5 \mathrm{C}_{6} \mathrm{H}_{6}, \mathrm{FW}=1121.94$, red block, $0.30 \times 0.24 \times 0.24 \mathrm{~mm}^{3}$, triclinic, $\mathrm{P} \overline{1}$ (no. 2), $\mathrm{a}=9.3430(6), \mathrm{b}=12.4727(6), \mathrm{c}=27.2186(14) \AA, \alpha=89.538(3), \beta=81.608(3), \gamma=68.083(4)^{\circ}, \mathrm{V}$ $=2907.4(3) \AA^{3}, Z=2, D_{x}=1.282 \mathrm{~g} / \mathrm{cm}^{3}, \mu=0.48 \mathrm{~mm}^{-1} .198636$ Reflections were measured on a Bruker Kappa CCD diffractometer with sealed tube and graphite monochromator $(\lambda=0.71073 \AA)$ at a temperature of $150(2) \mathrm{K}$ up to a resolution of $(\sin \theta / \lambda)_{\max }=0.66 \AA^{-1}$. The crystal appeared to be broken in several fragments. Five orientation matrices for the major fragments were used for the integration with the Eval15 software ${ }^{[\mathrm{S} 2]}$ and the reflection data were stored in the HKLF5 format. ${ }^{[\mathrm{S} 3]}$ A multiscan absorption correction and scaling was performed with TWINABS $^{[S 4]}$ (correction range 0.63-0.75). 14521 Reflections were unique $\left(R_{\text {int }}=0.071\right)$, of which 10751 were observed $[I>2 \sigma(I)]$. The structure was solved with Patterson superposition methods using SHELXT. ${ }^{[\mathrm{S} 5]}$ Least-squares refinement was performed with SHELXL-2016 ${ }^{[\mathrm{S} 6]}$ against $\mathrm{F}^{2}$ of all reflections. Non-hydrogen atoms were refined freely with anisotropic displacement parameters. The assignment of $\mathrm{P}$ versus Si could not be based on the electron density but was taken from the chemical knowledge. Hydrogen atom $\mathrm{H} 2$ was refined with distance restraints of 1.66(1) Å to Si2 and 1.49(1) to Ni1. All other hydrogen atoms were included in calculated positions and refined with a riding model. 712 Parameters were refined with 2 restraints (distances of H2). R1/wR2 [I > 2 $\sigma(\mathrm{I})$ ]: $0.0656 / 0.1821 . \mathrm{R} 1 / \mathrm{wR} 2$ [all refl.]: 0.0926 / 0.1948. S = 1.112. Batch scale factors BASF $=0.2760(19), 0.195(3), 0.1717(19)$ and 0.0444(18). Residual electron density between -0.44 and $0.77 \mathrm{e} / \AA^{3}$. Geometry calculations and checking for higher symmetry was performed with the PLATON program. ${ }^{[\mathrm{S} 7]}$

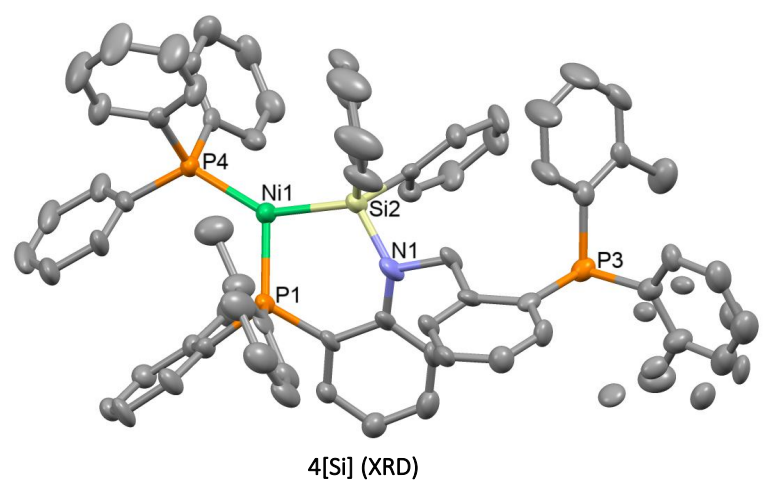

Figure S29. X-ray crystal structure 4 [Si], hydrogen atoms omitted for clarity and ellipsoids are show at $50 \%$ probability.

4[Si]: $\mathrm{C}_{71} \mathrm{H}_{64} \mathrm{NNiP}_{3} \mathrm{Si}+$ disordered solvent, $\mathrm{FW}=1110.94^{[*]}$, red block, $0.15 \times 0.07 \times 0.05 \mathrm{~mm}^{3}$, triclinic, $\mathrm{P} \overline{1}$ (no. 2), $\mathrm{a}=13.0477(9), \mathrm{b}=13.9732(9), \mathrm{c}=16.6323(10) \AA, \alpha=91.756(3), \beta=93.847(2)$, $\gamma=90.943(2)^{\circ}, \mathrm{V}=3023.6(3) \AA^{3}, \mathrm{Z}=2, \mathrm{D}_{\mathrm{x}}=1.220 \mathrm{~g} / \mathrm{cm}^{\left.3{ }^{3 *}\right]}, \mu=0.46 \mathrm{~mm}^{-1\left[^{*}\right]} .30962$ Reflections were measured on a Bruker Kappa ApexII diffractometer with sealed tube and Triumph monochromator $(\lambda$ $=0.71073 \AA)$ at a temperature of $150(2) \mathrm{K}$ up to a resolution of $(\sin \theta / \lambda)_{\max }=0.50 \AA^{-1}$. The Eval15 software $^{[\mathrm{S} 2]}$ was used for the intensity integration. A multiscan absorption correction and scaling was performed with SADABS ${ }^{[S 4]}$ (correction range 0.65-0.75). 6313 Reflections were unique $\left(\mathrm{R}_{\text {int }}=0.117\right)$, of which 3778 were observed $[I>2 \sigma(I)]$. The structure was solved with Patterson superposition methods using SHELXT. ${ }^{[\mathrm{S} 5]}$ Least-squares refinement was performed with SHELXL-2016 ${ }^{[\mathrm{S} 6]}$ against $\mathrm{F}^{2}$ of all reflections. The crystal structure contains large voids ( $200 \AA^{3} /$ unit cell) filled with severely disordered solvent molecules. Their contribution to the structure factors was secured by back-Fourier transformation using the SQUEEZE algorithm ${ }^{[\mathrm{S} 8]}$ resulting in 40 electrons / unit cell. Non-hydrogen 
atoms were refined freely with anisotropic displacement parameters. The assignment of $\mathrm{P}$ versus $\mathrm{Si}$ could not be based on the electron density but was taken from the chemical knowledge. One of the $p$ tolyl groups was refined with a disorder model. Hydrogen atom $\mathrm{H} 2$ was refined with distance restraints of 1.66(1) $\AA$ to Si2 and 1.49(1) to Ni1. All other hydrogen atoms were included in calculated positions and refined with a riding model. 766 Parameters were refined with 852 restraints (distance restraints for $\mathrm{H} 2$ and for the disordered groups, angle restraints for the disordered groups, and restrained displacement

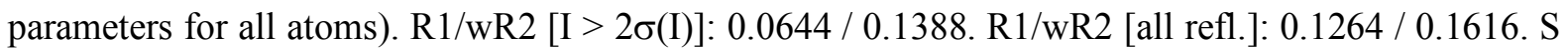
$=1.069$. Residual electron density between -0.35 and $0.48 \mathrm{e} / \AA^{3}$. Geometry calculations and checking for higher symmetry was performed with the PLATON program. ${ }^{[\mathrm{S} 7]}$

[*] derived values do not contain the contribution of the disordered solvent.

2[SiPhMe]: $\mathrm{C}_{62} \mathrm{H}_{54} \mathrm{NNiP}_{3} \mathrm{Si} \cdot \mathrm{C}_{6} \mathrm{H}_{6}, \mathrm{FW}=1070.88$, orange-red block, $0.34 \times 0.32 \times 0.26 \mathrm{~mm}^{3}$, monoclinic, $\mathrm{C} 2 / \mathrm{c}$ (no. 15), $\mathrm{a}=43.1409(8), \mathrm{b}=10.68157(16), \mathrm{c}=24.4193(4) \AA, \beta=104.906(1)^{\circ}, \mathrm{V}=$ 10874.1(3) $\AA^{3}, Z=8, D_{x}=1.308 \mathrm{~g} / \mathrm{cm}^{3}, \mu=0.51 \mathrm{~mm}^{-1}$. The diffraction experiment was performed on a Bruker Kappa ApexII diffractometer with sealed tube and Triumph monochromator $(\lambda=0.71073 \AA)$ at a temperature of $150(2) \mathrm{K}$ up to a resolution of $(\sin \theta / \lambda)_{\max }=0.65 \AA^{-1}$. The Eval15 software ${ }^{[\mathrm{S} 2]}$ was used for the intensity integration. A multi-scan absorption correction and scaling was performed with $\mathrm{SADABS}^{[\mathrm{S} 4]}$ (correction range 0.70-0.75). A total of 117052 reflections was measured, 12472 reflections were unique $\left(R_{\text {int }}=0.033\right), 10521$ reflections were observed $[I>2 \sigma(I)]$. The structure was solved with Patterson superposition methods using SHELXT. ${ }^{[S 5]}$ Structure refinement was performed with SHELXL-2017 ${ }^{[\mathrm{S} 6]}$ on $\mathrm{F}^{2}$ of all reflections. Non-hydrogen atoms were refined freely with anisotropic displacement parameters. All hydrogen atoms were located in difference-Fourier maps. Hydrogen $\mathrm{H} 1$ was refined freely with an isotropic displacement parameter. All other hydrogen atoms were refined with a riding model. 672 Parameters were refined with no restraints. R1/wR2 [I $>2 \sigma(I)]$ : $0.0342 / 0.0948 . \mathrm{R} 1 / \mathrm{wR} 2$ [all refl.]: $0.0434 / 0.1001 . \mathrm{S}=1.034$. Residual electron density between -0.41 and $0.80 \mathrm{e} / \AA^{3}$. Geometry calculations and checking for higher symmetry was performed with the PLATON program. ${ }^{[\mathrm{S} 7]}$

CCDC 1960190-1960192 contain the supplementary crystallographic data for this paper. These data can be obtained free of charge from The Cambridge Crystallographic Data Centre via www.ccdc.cam.ac.uk/data_request/cif. 


\section{Additional discussions}

\subsection{Discussion of $2\left[\mathrm{SiD}_{2}\right]$ and $2[\mathrm{SiPhMe}]$}

As anticipated for an imine hydrosilylation reaction, addition of $\mathrm{Ph}_{2} \mathrm{SiD}_{2}$ to 2 resulted in the deuterium

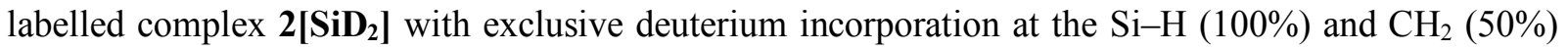
positions. Analysis of $\mathbf{2}\left[\mathbf{S i D}_{2}\right]$ by NMR shows spectra similar to $2[\mathbf{S i}]$, but with the incorporation of an extra deuterium coupling in the ${ }^{31} \mathrm{P}$ NMR spectrum, and the absence of the hydride peak in ${ }^{1} \mathrm{H}$ NMR. The ${ }^{2} \mathrm{H}$ NMR spectrum shows a broad signal at $-2.6 \mathrm{ppm}$ for $\mathrm{Si}-\mathrm{D}$. The geminal $-\mathrm{CHD}$ signals are observed as two singlet signals in ${ }^{1} \mathrm{H}$ NMR with similar intensity, indicating the random positioning of the deuterium atom over the two diastereotopic sites. This is a result of chemical exchange between these two positions - likely via reversible decoordination of the phosphine tethers causing racemization of the nickel center - as was also observed by VT NMR.

The prochiral silane $\mathrm{PhMeSiH}_{2}$ adds cleanly to compound 2 in $\mathrm{C}_{6} \mathrm{D}_{6}$, and forms an equilibrium mixture of two diastereomers as evident from NMR analysis (Figure S30). The two diastereomers of 2 [SiPhMe] originate from the presence of two tetrahedral stereocenters at $\mathrm{Si}$ and $\mathrm{Ni}$, presumably equilibrating via racemization of the Ni-center. This means that the silicon-bound methyl group can be orientated toward the imine- $\mathrm{N}$ or to the imine-C (Figure 2).

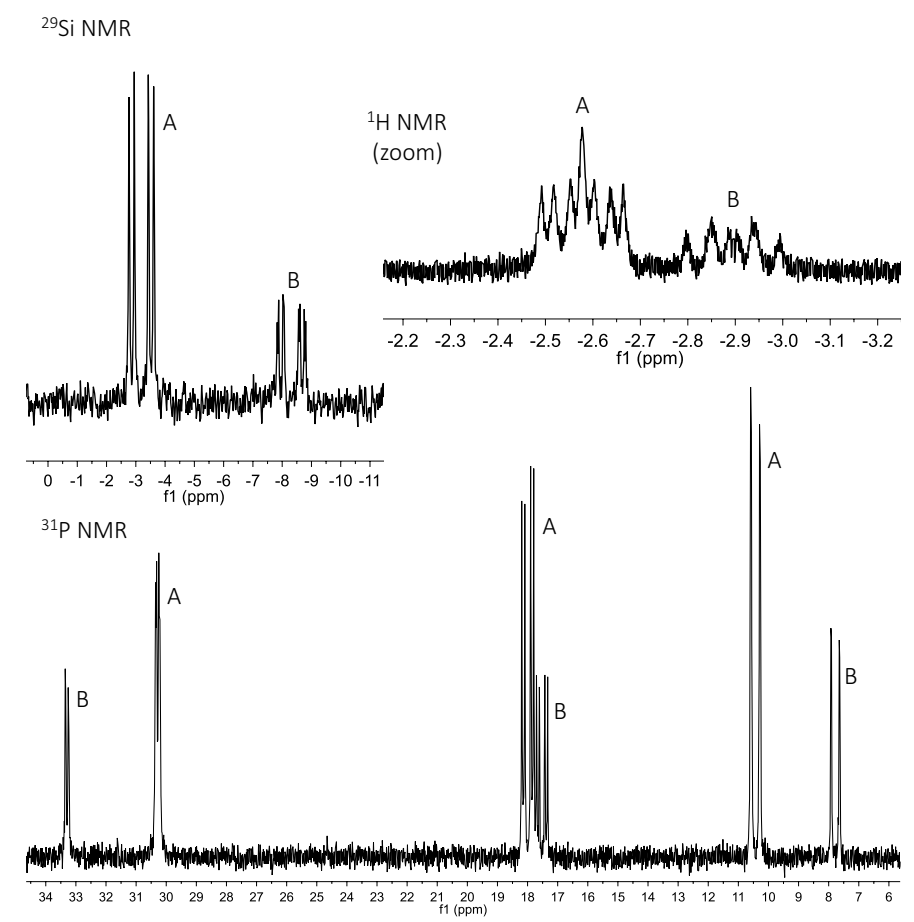

Figure S30. NMR spectra of 2[SiPhMe]. A: major species, B: minor species. 


\subsection{Locating the Si-H using DFT calculations}

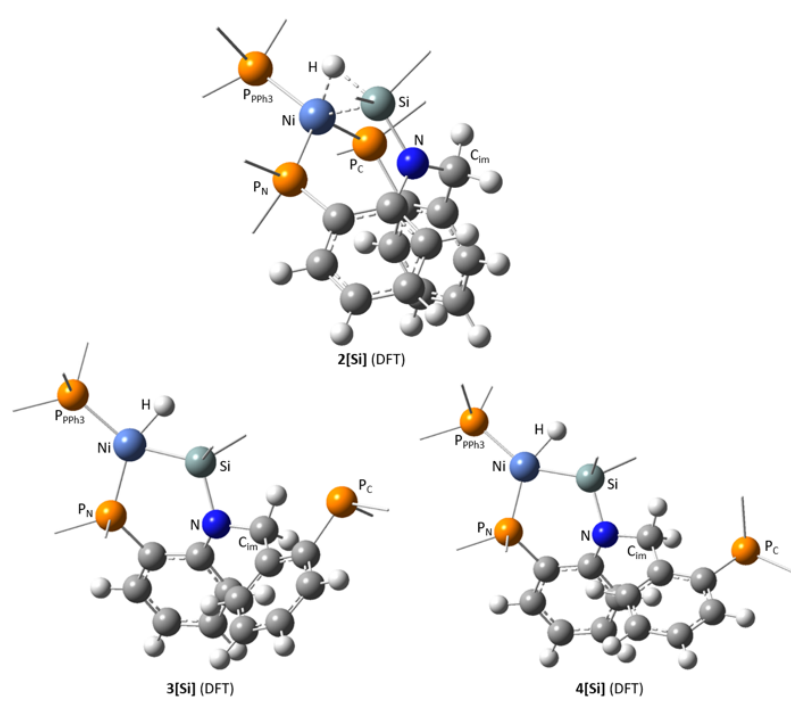

Figure S31. DFT calculated structures of 2 [Si], 3[Si] and 4[Si] at the M06L/6-31g(d,p) level of theory with added dispersion correction (GD3). Phenyl rings are omitted for clarity, and positioning of the rings are shown. Selected bond distances and angles are shown in Table S1.

Table S1. Comparison of selected bond lengths and angles of 2[Si] and 3[Si], as calculated by DFT (M06L/6$3 \lg (\mathrm{d}, \mathrm{p})$ level of theory with added dispersion correction (GD3)) and the X-ray crystal structures. Bond lengths are given in $\AA$ and bond angles in ${ }^{\circ}$.

\begin{tabular}{|l|l|l|l|l|l|}
\hline & $\mathbf{2}[\mathbf{S i}]$ DFT & $\mathbf{3}[\mathbf{S i}]$ XRD & $\mathbf{3}[\mathbf{S i}]$ DFT & 4[Si] XRD & 4[Si] DFT \\
\hline $\mathrm{Ni}-\mathrm{H}$ & 1.55 & - & 1.51 & - & 1.51 \\
\hline $\mathrm{Si}-\mathrm{H}$ & 1.71 & - & 1.89 & - & 1.89 \\
\hline $\mathrm{Ni}-\mathrm{Si}$ & 2.24 & $2.1864(13)$ & 2.15 & $2.196(2)$ & 2.16 \\
\hline $\mathrm{Si}-\mathrm{N}$ & 1.79 & $1.800(4)$ & 1.83 & $1.781(7)$ & 1.83 \\
\hline $\mathrm{N}-\mathrm{C}_{\mathrm{im}}$ & 1.47 & $1.470(6)$ & 1.46 & $1.492(9)$ & 1.46 \\
\hline $\mathrm{Ni}-\mathrm{PPh}_{3}$ & 2.24 & $2.1852(13)$ & 2.18 & $2.213(2)$ & 2.18 \\
\hline $\mathrm{Ni}-\mathrm{P}_{\mathrm{N}}$ & 2.20 & $2.1194(13)$ & 2.11 & $2.143(2)$ & 2.11 \\
\hline $\mathrm{Ni}-\mathrm{P}_{\mathrm{C}}$ & 2.21 & $7.6617(15)$ & 7.54 & $7.690(2)$ & 7.57 \\
\hline $\mathrm{Si}-\mathrm{Ni}-\mathrm{H}$ & 50 & - & 59 & - & 59 \\
\hline $\mathrm{PPh}_{3}-\mathrm{Ni}-\mathrm{H}$ & 86 & - & 90 & - & 90 \\
\hline
\end{tabular}




\section{Computational details}

\subsection{Functional choice}

First we evaluated the accuracy of the DFT method, by using the silane scrambling between 2 [Si] and 2[SiPhMe] (Figure 6, main text) and the equilibrium reaction between the two diasteroisomers of 2[SiPhMe] as models (Figure 2, S30). M06L/def2TZVP//M06L/6-31g(d,p) calculation with added dispersion correction (empirical dispersion $=\mathrm{gd} 3)^{[\mathrm{S} 10]}$ and the SMD (solvation based on density) benzene model correlates to the experimental values measured by ${ }^{1} \mathrm{H}$ NMR. We therefore chose that level of theory to evaluate the thermodynamic parameters of the intermediates in the $\mathrm{C}=\mathrm{N}$ hydrosilylation of compound $\mathbf{2}$ into $\mathbf{2}[\mathbf{S i}]$.

A.

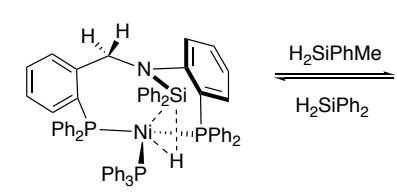

$2[\mathrm{Si}]$

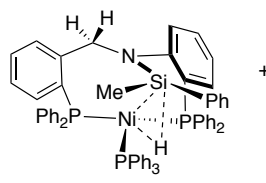

$2[\mathrm{SiPhMe}]^{1}$

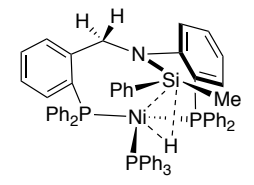

$2[\mathrm{SiPhMe}]^{2}$

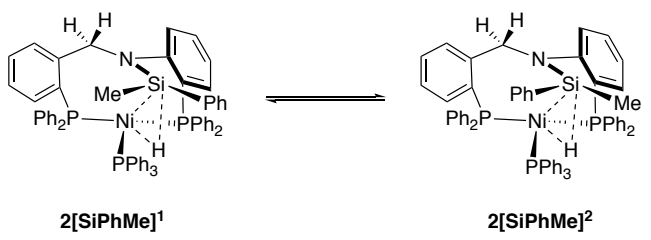

Scheme S1. Method for the experimental and computational determination of $K_{\text {eq }}$ and $\Delta G^{\circ}$ (left to right). A. Silane scrambling reaction between $2[\mathbf{S i}]$ and $2[\mathrm{SiPhMe}$. B. Equilibrium mixture of the two diasteroisomers of 2[SiPhMe], i.e. 2[SiPhMe] ${ }^{1}$ and $2[\text { SiPhMe }]^{2}$.

\subsubsection{Method}

The standard Gibbs free energy ( $\Delta \mathrm{G}^{\circ}$, left to right) of the silane scrambling reaction between 2 [Si] and $2[\mathrm{SiPhMe}]\left(2[\mathrm{SiPhMe}]=2\right.$ [SiPhMe $^{1}+2\left[\mathrm{SiPhMe}^{2}\right)($ Scheme S1, A) and between the two diasteroisomers of 2[SiPhMe] (Scheme S1, B) was experimentally measured by ${ }^{1} \mathrm{H}$ NMR and calculated according to the following formula:

$$
\Delta \mathrm{G}^{\circ}=-\mathrm{R} \ln \left(\mathrm{K}_{\text {eq }}\right)=-\mathrm{R} \ln \frac{\prod_{\mathrm{n}}^{\mathrm{i}=1} \mathrm{a}(\text { product })_{\mathrm{i}}}{\prod_{\mathrm{n}}^{\mathrm{i}=1} \mathrm{a}(\text { reactant })_{\mathrm{i}}} \approx-\mathrm{R} \ln \frac{\prod_{\mathrm{n}}^{\mathrm{i}=1} \mathrm{C}(\text { product })_{\mathrm{i}}}{\prod_{\mathrm{n}}^{\mathrm{i}=1} \mathrm{C}(\text { reactant })_{\mathrm{i}}}
$$

With $\mathrm{R}=$ The gas constant $=1.987 \cdot 10^{-3} \mathrm{kcal} \cdot \mathrm{mol}^{-1} \cdot \mathrm{K}^{-1} ; \mathrm{T}=$ The temperature of the reaction, $\mathrm{K}_{\mathrm{eq}}=$ The standard equilibrium constant; $\mathrm{a}=$ activity; $\mathrm{C}=$ molar concentration. The relative concentration between the reactants and products were determined by ${ }^{1} \mathrm{H}$ NMR at a temperature of $\mathrm{T}=298.15 \mathrm{~K}$.

Table S2 provides a description of the relative concentrations measured by NMR over two experiments.

Table S2. Relative concentrations of the products and reactants determined by NMR over two experiments.

\begin{tabular}{l|ccccc}
\hline & $\mathbf{H}_{\mathbf{2}} \mathbf{S i P h M e}$ & $\mathbf{H}_{\mathbf{2}} \mathbf{S i P h}_{\mathbf{2}}$ & $\mathbf{2}[\mathbf{S i}]$ & $\mathbf{2 [ S i P h M e}^{\mathbf{1}}$ & 2[SiPhMe $^{\mathbf{1}}$ \\
\cline { 2 - 6 } NMR 1 & 0.33 & 0.44 & 0.45 & 0.40 & 0.16 \\
NMR 2 & 0.33 & 0.46 & 1.04 & 0.84 & 0.34 \\
\hline
\end{tabular}

Over two NMR experiments, an average standard Gibbs free energy $\left(\Delta G^{\circ}\right)$ was calculated for the two equilibrium reactions:
A. $\Delta \mathbf{G}^{\circ}=-\mathbf{0 . 2 8} \mathbf{~ k c a l} / \mathbf{m o l}($ Scheme $\mathrm{S} 1, \mathrm{~A})$
B. $\Delta \mathbf{G}^{\circ}=-\mathbf{0 . 5 4} \mathrm{kcal} / \mathbf{m o l}($ Scheme S1, B) 


\subsubsection{Experimental procedure and characterization}

Under $\mathrm{N}_{2}$ atmosphere, $\mathrm{PhMeSiH}_{2}(0.8 \mu \mathrm{L}, 5.4 \mathrm{mmol})$ and $\mathrm{Ph}_{2} \mathrm{SiH}_{2}(1.0 \mu \mathrm{L}, 5.4 \mathrm{mmol})$ were added via a microsyringe to a $\mathrm{C}_{6} \mathrm{D}_{6}$ a solution $(0.7 \mathrm{~mL})$ of $2(4.8 \mathrm{mg}, 5.4 \mathrm{mmol})$. The reaction mixture was stirred for 17 hours at room temperature and then transferred to a Young-type NMR tube for ${ }^{1} \mathrm{H}$ and ${ }^{31} \mathrm{P}$ NMR analysis. In ${ }^{1} \mathrm{H}$ NMR spectrum (Figure S32), the peaks denoted: a (methylphenylsilane), b (diphenylsilane), c (2[SiPhMe $\left.{ }^{2}\right), d(2[\mathbf{S i}])$ and e $\left(2[\mathbf{S i P h M e}]^{1}\right)$ were chosen in order to determine the relative concentrations of the products $\left(2[\mathrm{SiPhMe}]^{1}, 2[\mathbf{S i P h M e}]^{2}, \mathrm{H}_{2} \mathrm{SiPh}_{2}\right)$ and reactants $(2[\mathbf{S i}]$ and $\mathrm{H}_{2} \mathrm{SiPhMe}$ ).

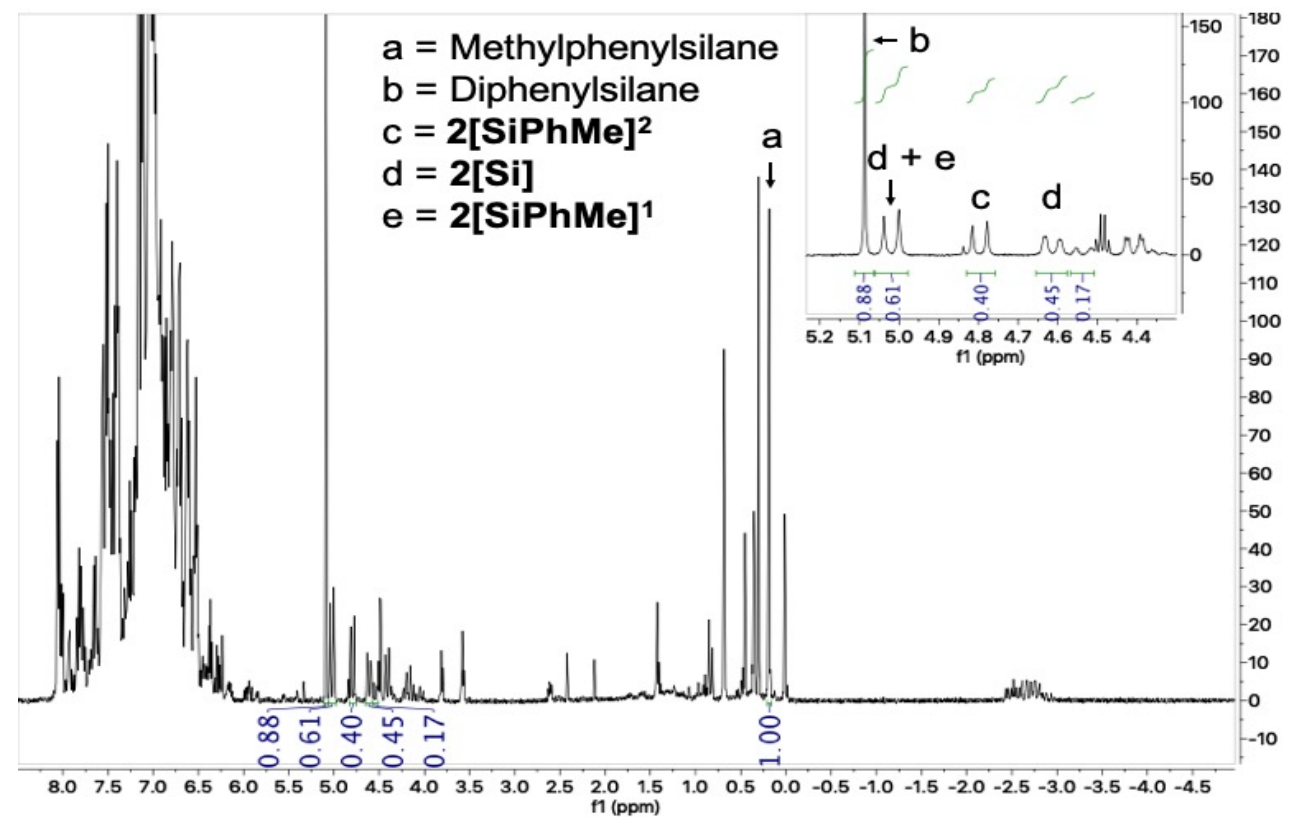

Figure S32. ${ }^{1} \mathrm{H}$ NMR $\left(\mathrm{C}_{6} \mathrm{D}_{6}\right)$ of the silane scrambling reaction between $2[\mathrm{Si}]$ and 2 [SiPhMe]. Spectrum from NMR experiment 1.

\subsubsection{DFT method}

The structures were first optimized at different levels of theory (i.e. B3LYP, BP86, M06L, and M06) with added dispersion correction $(\mathrm{gd} 3)^{[\mathrm{S} 2]}$ and the $6-31 \mathrm{~g}(\mathrm{~d}, \mathrm{p})$ basis set on all atoms. The optimized geometries are all minima, which was evaluated by the lack of negative vibrational frequencies. Subsequently, the free Gibbs energies of formation $\left(\mathrm{G}^{\circ}\right)$ of reactants and products were calculated at a temperature of $\mathrm{T}=298.15 \mathrm{~K}$ and at a default pressure of $1 \mathrm{~atm}$ from the optimized structures by single point (SP) calculation and by adding the thermal correction to the Gibbs free energy. SP was calculated with added dispersion correction ( $g d 3$ ), the SMD (solvation based on density) benzene solvent model, and the def2TZVP basis set on all atoms. The $\Delta \mathrm{G}^{\circ}$ of the reactions are reported in Table $\mathrm{S} 3$ and were calculated with: B3LYP (Becke, three-parameter, Lee-Yang-Parr); BP86 (Beck, Perdew 86); M06L (Minnesota 2006, local); M06 (Minnesota 2006) functionals. $\Delta \mathrm{G}^{\circ}$ from Scheme S1 were determined according to the following formula:

$$
\left.\Delta \mathrm{G}^{\circ} \text { (left to right }\right)=\sum_{n}^{i=1} \mathrm{G}^{\circ}(\text { product }) \mathrm{i}-\sum_{n}^{i=1} \mathrm{G}^{\circ}(\text { reactant }) \mathrm{i}
$$

\footnotetext{
$\Leftrightarrow$

A. $\Delta \mathrm{G}^{\circ}$ (left to right $)=\mathrm{G}^{\circ}\left(2[\mathbf{S i P h M e}]^{1}\right)+\mathrm{G}^{\circ}\left(2[\mathbf{S i P h M e}]^{2}\right)+\mathrm{G}^{\circ}\left(\mathrm{H}_{2} \mathrm{SiPh}_{2}\right)-\mathrm{G}^{\circ}(2[\mathbf{S i}])-\mathrm{G}^{\circ}$ $\left(\mathrm{H}_{2} \mathrm{SiPhMe}\right)$

B. $\Delta \mathrm{G}^{\circ}$ (left to right $)=\mathrm{G}^{\circ}\left(2[\text { SiPhMe }]^{2}\right)-\mathrm{G}^{\circ}\left(2[\text { SiPhMe }]^{1}\right)$
} 
Table S3. Comparison of DFT methods for determination of the standard Gibbs free energy of the reaction $\left(\Delta \mathrm{G}^{\circ}\right)$.

\begin{tabular}{l|ccccc}
\hline & \multicolumn{5}{|c}{ DFT Method } \\
Reaction & B3LYP & BP86 & M06L & M06 & Exp \\
\hline A & 1.9 & 4.1 & 2.1 & 6.4 & $-\mathbf{0 . 3}$ \\
B & -1.0 & -0.4 & -0.4 & 1.0 & $-\mathbf{0 . 5}$ \\
\hline
\end{tabular}

\subsubsection{General considerations}

DFT (density functional theory) results were obtained using the Gaussian 09 software package. ${ }^{[\mathrm{S} 9]}$ Restricted (R) geometry optimizations use the M06L (Minnesota 2006, local) functional and the 6$3 \lg (\mathrm{d}, \mathrm{p})$ basis set on all atoms. The structures were optimized with added empirical dispersion $(\mathrm{gd} 3)^{[\mathrm{S} 2]}$ and are either minima or transition states, as checked by the presence of 0 or 1 imaginary frequency, respectively. Frequency analyses were performed on all calculations at a M06L/6-31g(d,p) level of theory with dispersion correction ( $\mathrm{gd} 3)$. The transition states search was performed using the QST3 (synchronous transit-guided quasi Newton number 3) method using a transition state guess that was located by a rigid potential energy surface (PES) scan (opt = modredundant) connecting the reactant and product. Reported Gibbs free energies correspond to M06L/def2TZVP//M06L/6-31g(d,p) level of theory with the SMD (solvation based on density) benzene solvent model and added empirical dispersion ( $g d 3)$. Thermochemical calculations were performed at a temperature of $298.15 \mathrm{~K}$ and at a default pressure of $1 \mathrm{~atm}$. Pictures derived from DFT calculations have been generated using the GaussView software. The M06L functional was chosen as it as it has been shown to be accurate for energy calculations of related metal compounds, ${ }^{[\mathrm{S} 11]}$ and as the calculated thermodynamic parameter $\left(\Delta G^{\circ}\right)$ correlates with the experimental value measured by ${ }^{1} \mathrm{H}$ NMR for (i) the silane scrambling reaction: $\mathbf{2}[\mathbf{S i}]+\mathrm{H}_{2} \mathrm{SiPhMe} \rightleftarrows \mathbf{2}[\mathbf{S i P h M e}]+\mathrm{H}_{2} \mathrm{SiPh}_{2}$ and (ii) the equilibrium reaction: 2 [SiPhMe] ${ }^{1} \rightleftarrows$ $2[\mathrm{SiPhMe}]^{2}$.

\subsection{DFT calculated alternative reaction pathways}

An alternative pathway, akin to the modified Chalk-Harrod mechanism, in which the N-Si bond is formed prior to the $\mathrm{C}-\mathrm{H}$ bond, was discarded because the key intermediate 2[I-3b] (Figure 5; blue line) lies significantly higher in free energy $\left(\Delta G^{\circ}=27.7 \mathrm{kcal} / \mathrm{mol}\right)$. In addition, the transfer of the silyl moiety from 2[I-2] to the nitrogen atom and formation of intermediate $2[\mathbf{I}-3 \mathbf{b}]$ is sterically not favorable (Figure $\mathrm{S} 44, \mathrm{~S} 45)$. Furthermore, the formation of 2 [Si] via the direct addition of $\mathrm{Ph}_{2} \mathrm{SiH}_{2}$ into the ligand backbone $\left(\mathbf{1}^{\mathrm{Ph}}\right)$, without the participation of $\mathrm{Ni}$, is unlikely as no transition state could be located for this pathway. Experimentally, no hydrosilylation of the $\mathrm{C}=\mathrm{N}$ moiety was observed upon treatment of the ligand $\mathbf{1}^{\mathrm{Ph}}$ with $\mathrm{Ph}_{2} \mathrm{SiH}_{2}$ (see Section 7.3.2).

The silyl transfer to the $\mathrm{N}$ atom with the formation a $\sigma$-coordinating $\mathrm{Si}-\mathrm{H}$ bond to $\mathrm{Ni}$ proved complicated by the accessibility of several ligand binding modes, and the full reaction pathway could not be identified (Figure S33, top). From 2[I-3], two distinct transition states were identified for the generation of 2[I-4] via the $\mathrm{Si}$ transfer to the nitrogen moiety and formation of a new $\mathrm{Ni}-\mathrm{H}$ bond (Figure $\mathrm{S} 33$, bottom). The imaginary frequency of both transition states is characterized by the transfer of $\mathrm{Ph}_{2} \mathrm{SiH}$ to the $\mathrm{N}$ atom ( $\mathrm{Si}-\mathrm{N}: 2.96 \AA$ for 2[TS2a], $\mathrm{Si}-\mathrm{N}: 2.99 \AA$ for 2[TS2b]). 2[TS2a] has an $\eta^{2}$-interaction of $\mathrm{Ni}$ with one phenyl substituent $\left(\mathrm{Ni}-\mathrm{C}_{\mathrm{Ar} 1}: 2.11 \AA, \mathrm{Ni}-\mathrm{C}_{\mathrm{Ar} 2}: 2.24 \AA\right.$ ), while in 2[TS2a], the $\mathrm{Si}-\mathrm{H}$ bond is $\eta^{2}$-coordinated to Ni (Ni-H1: $1.65 \AA$, Ni-Si: $2.09 \AA$, Si-H1:1.65 $\AA$ ). However, geometry optimization after slight displacement along the imaginary mode does not connect them back to intermediates 2[I-3] or 2[I-4] (dotted line), suggesting more complex pathways. Additionally, both 2[TS2a] $\left(\Delta \mathrm{G}^{\circ, \$}=27.4\right.$ $\mathrm{kcal} / \mathrm{mol}$, Figure S33; black line) and 2[TS2b] $\left(\Delta \mathrm{G}^{\circ, \star}=32.4\right.$. kcal $/ \mathrm{mol}$, Figure S33; orange line) lie too high in energy for a reaction occurring rapidly at room temperature. Hence, a more complicated route from 2[I-3] to 2[I-4] is probably in place. Stepwise pathways in which one phosphine arm of the ligand decoordinates before the Si transfer (Figure S48, S49) or transient coordination of the solvent (benzene) 
may be envisioned. Finally, reassociation of the triphenyl phosphine co-ligand to 2 [I-4] results in the observed product $2[\mathbf{S i}$ ], with an overall free Gibbs energy of the reaction of $-8.7 \mathrm{kcal} / \mathrm{mol}$.

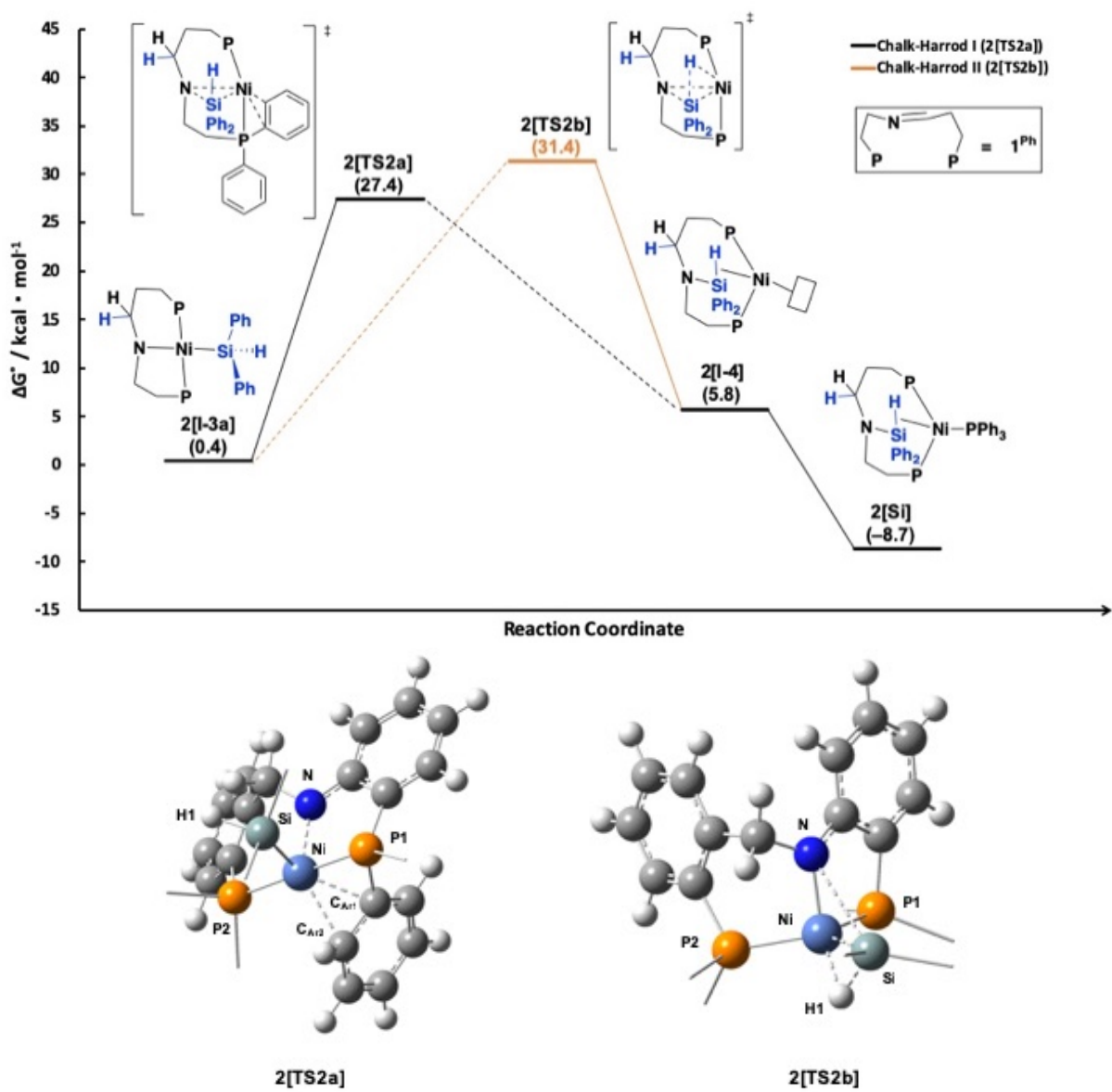

Figure S33. The silyl transfer step from 2[I-3a] to 2 [Si]. Top: proposed energy surface, as calculated at a $\mathrm{M} 06 \mathrm{~L} / \mathrm{def} 2 \mathrm{TZVP} / \mathrm{M} 06 \mathrm{~L} / 6-31 \mathrm{~g}(\mathrm{~d}, \mathrm{p})$ level of theory with added dispersion correction and the SMD benzene model. Values in parentheses are given in $\mathrm{kcal} / \mathrm{mol}$. Dotted lines indicate that the TS is not connected to the intermediate. represents a free coordination site. Free $\mathrm{Ph}_{2} \mathrm{SiH}_{2}$ and $\mathrm{PPh}_{3}$ have been accounted for in the calculations, but were omitted for clarity in the figure. Bottom: transition state between 2[I-3a] and 2[I-4]. Selected bond distances $(\AA)$ for 2[TS2a]: Ni-Si: 2.09, Ni-H1: 2.96, Si-H1: 1.50, Ni-N: 1.98, Si-N: 2.96, Ni$\mathrm{C}_{\mathrm{Ar} 1}$ : 2.11, Ni-C $\mathrm{C}_{\mathrm{Ar} 2}: 2.24$. Selected bond distances $(\AA)$ for 2[TS2b]: Ni-Si: 2.09, Ni-H1: 1.65, Si-H1: 1.65, Ni$\mathrm{N}$ : 1.91, Si-N: 2.99. Phenyl substituents on phosphine and silicon are omitted in the figure for clarity.

\subsubsection{Coordination of a silane to $2[\mathrm{I}-1 \mathrm{~b}]$}

From the optimized geometry of $\mathbf{2}[\mathbf{I}-\mathbf{1} \mathbf{b}]$ (one phosphine arm from the ligand not coordinated while $\mathrm{PPh}_{3}$ still bound), coordination of a silane $\left(\mathrm{H}_{2} \mathrm{SiPh}_{2}\right.$ or less bulky $\left.\mathrm{SiH}_{4}\right)$ was attempted (Scheme $\mathrm{S} 2$ ). For all tested optimizations $\left(\mathrm{H}_{2} \mathrm{SiPh}_{2}\right.$ or $\mathrm{SiH}_{4}$ with different starting geometries), the structure only optimizes when the silane decoordinates. For this reason, this pathway has been discarded.

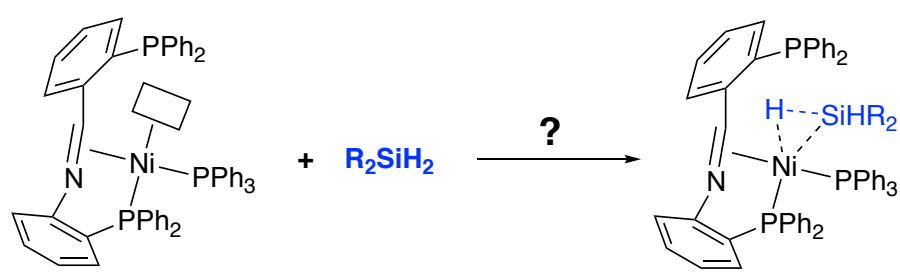

2[l-1b]

target geometry optimization

Scheme S2. Silane coordination to 2[I-b], as attempted by DFT calculation. $\mathrm{R}=\mathrm{Ph}$ or $\mathrm{H}$. represents a vacant coordination site. 


\subsubsection{Reaction of 2[I-1b] with the secondary silane $\mathrm{H}_{2} \mathrm{SiPh}_{2}$}

Geometry optimization I

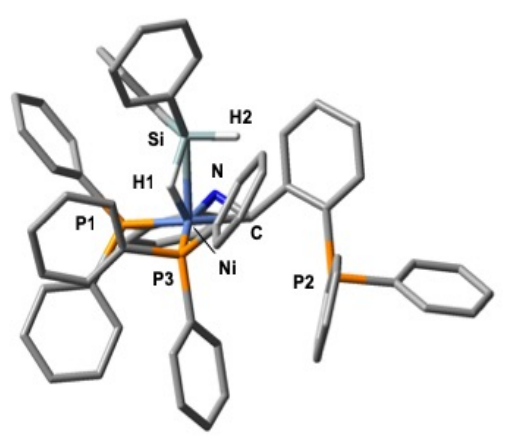

start optimization $\left(\mathrm{Ph}_{2} \mathrm{SiH}_{2}\right.$ bound)

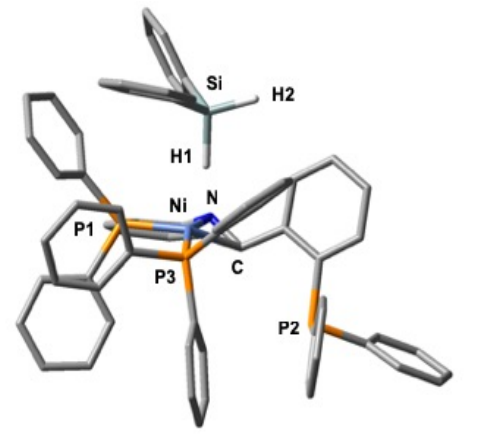

end optimization $\left(\mathrm{Ph}_{2} \mathrm{SiH}_{2}\right.$ not bound)

Figure S34. Geometry optimization of $2[\mathrm{I}-1 \mathbf{b}]+\mathrm{Ph}_{2} \mathrm{SiH}_{2}$ at a M06L/6-31g $(\mathrm{d}, \mathrm{p})$ level of theory with added empirical dispersion (gd3). Structure before (left) and after (right) optimization. Except H1 and H2, hydrogen atoms have been omitted for clarity.

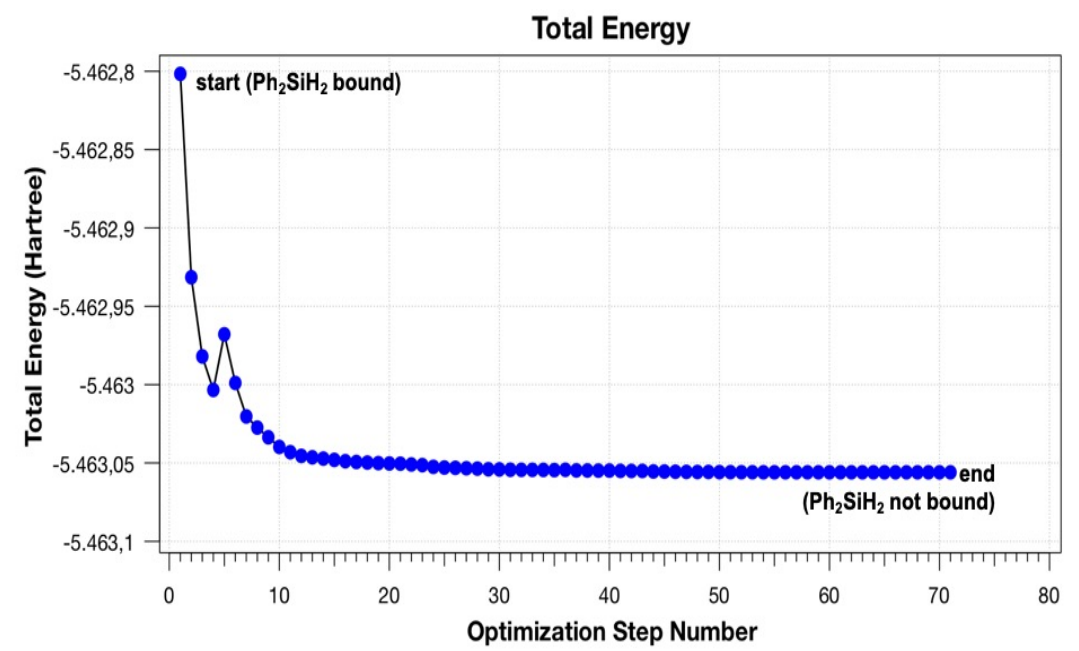

Figure S35. Geometry optimization of $2[\mathbf{I}-\mathbf{1 b}]+\mathrm{Ph}_{2} \mathrm{SiH}_{2}$ at a M06L/6-31g $(\mathrm{d}, \mathrm{p})$ level of theory with added empirical dispersion (gd3). Total energy diagram (in Hartree) according to the optimization step coordinate.

Geometry optimization II

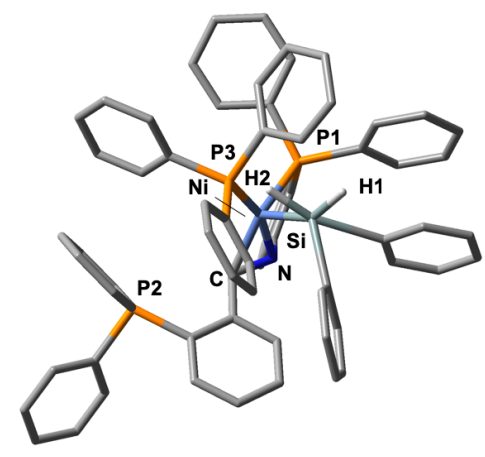

start optimization $\left(\mathrm{Ph}_{2} \mathrm{SiH}_{2}\right.$ bound)

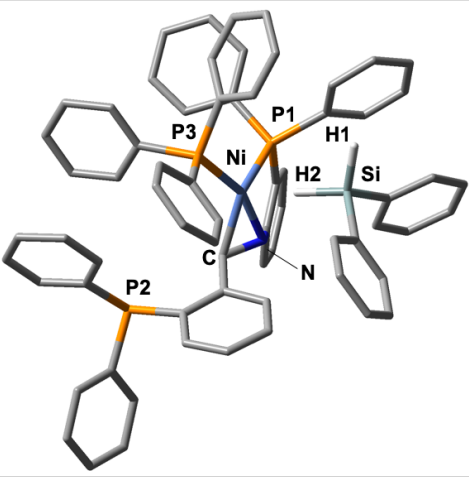

end optimization $\left(\mathrm{Ph}_{2} \mathrm{SiH}_{2}\right.$ not bound)

Figure S36. Geometry optimization of $2[\mathbf{I}-1 \mathbf{b}]+\mathrm{Ph}_{2} \mathrm{SiH}_{2}$ at a M06L/6-31g(d,p) level of theory with added empirical dispersion (gd3). Structure before (left) and after (right) optimization. Except H1 and H2, hydrogen atoms have been omitted for clarity. 


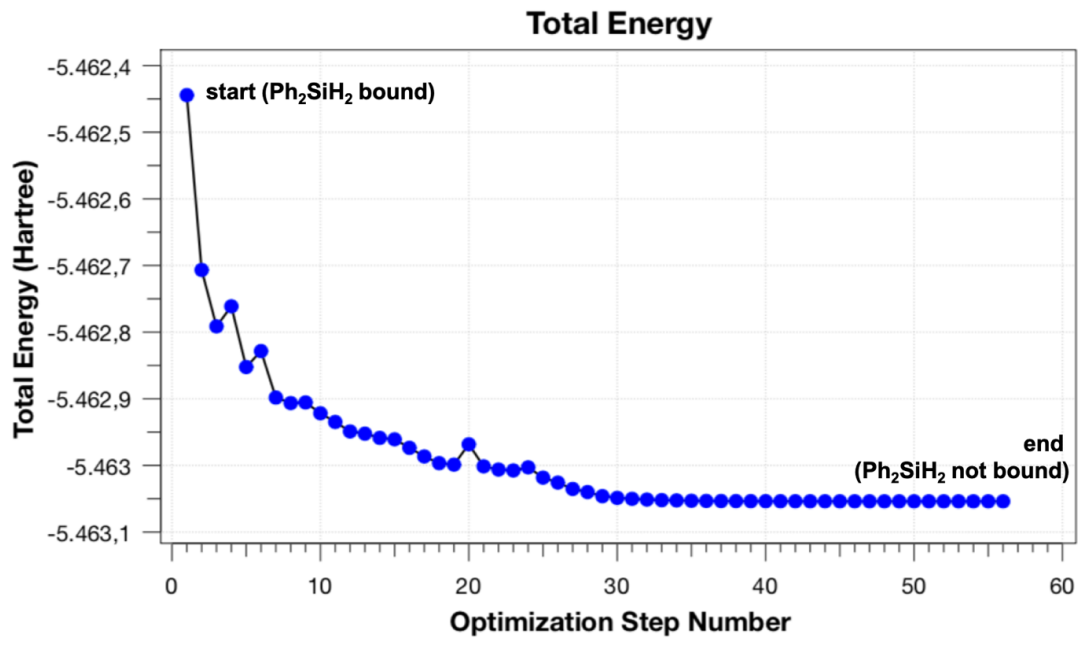

Figure S37. Geometry optimization of 2 [I-1b] $+\mathrm{Ph}_{2} \mathrm{SiH}_{2}$ at a M06L/6-31g(d,p) level of theory with added empirical dispersion (gd3). Total energy diagram (in Hartree) according to the optimization step coordinate.

\subsubsection{Reaction of $2[\mathrm{I}-1 \mathrm{~b}]$ with the quaternary silane $\mathrm{SiH}_{4}$}

Geometry optimization I

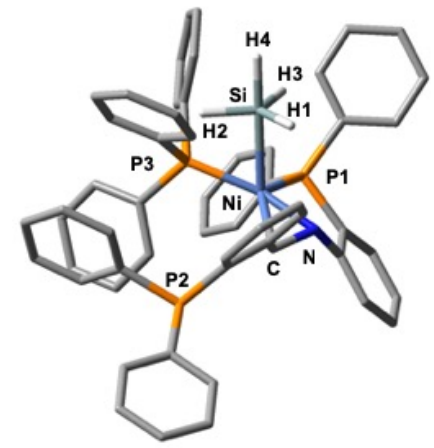

start optimization ( $\mathrm{SiH}_{4}$ bound)

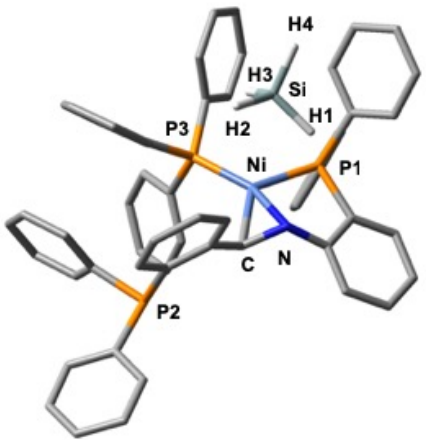

end optimization ( $\mathrm{SiH}_{4}$ not bound)

Figure S38. Geometry optimization of $\mathbf{2}[\mathbf{I}-\mathbf{1 b}]+\mathrm{SiH}_{4}$ at a M06L/6-31g $(\mathrm{d}, \mathrm{p})$ level of theory with added empirical dispersion (gd3). Structure before (left) and after (right) optimization. Except H1 to H4, hydrogen atoms have been omitted for clarity.

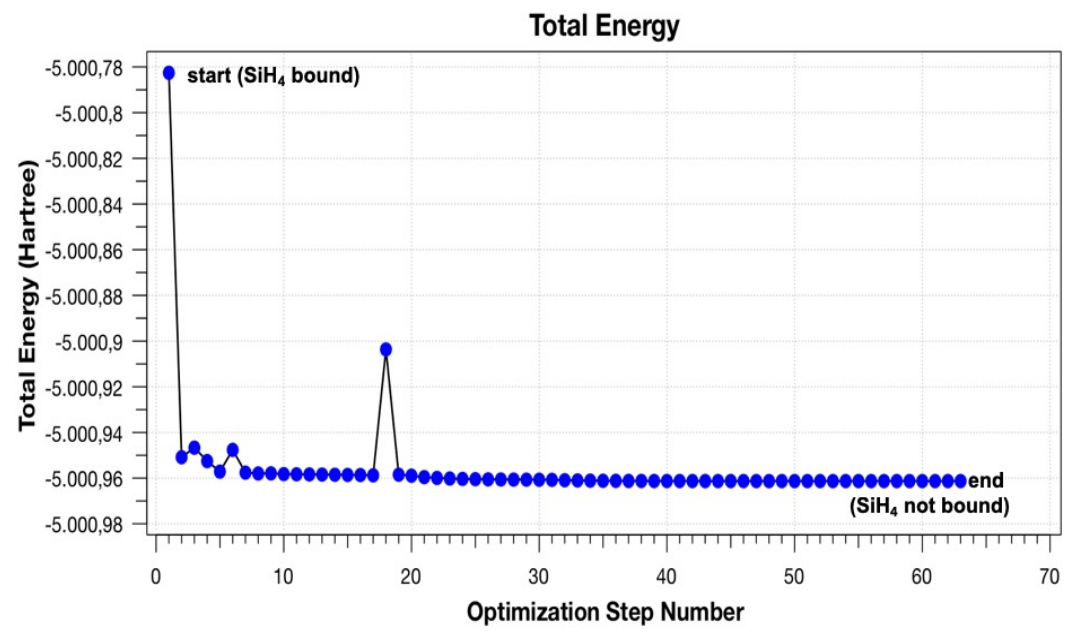

Figure S39. Geometry optimization of $2[\mathbf{I}-\mathbf{1 b}]+\mathrm{SiH}_{4}$ at a M06L/6-31g(d,p) level of theory with added empirical dispersion (gd3). Total energy diagram (in Hartree) according to the optimization step coordinate. 
Geometry optimization II

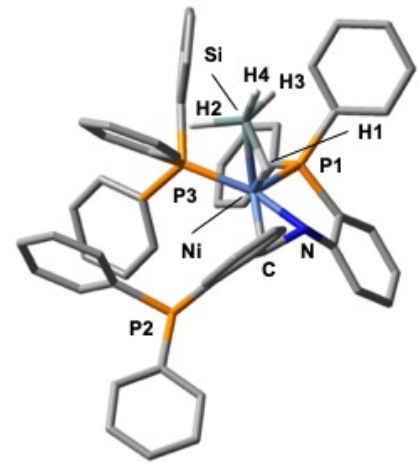

start optimization ( $\mathrm{SiH}_{4}$ bound)

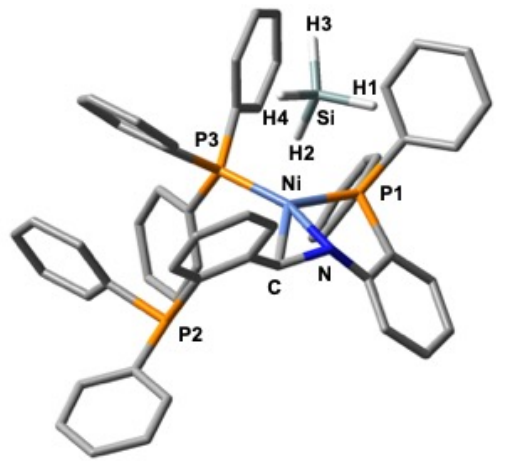

end optimization ( $\mathrm{SiH}_{4}$ not bound)

Figure S40. Geometry optimization of $\mathbf{2}[\mathbf{I}-\mathbf{1 b}]+\mathrm{SiH}_{4}$ at a M06L/6-31g $(\mathrm{d}, \mathrm{p})$ level of theory with added empirical dispersion (gd3). Top. Structure before (left) and after (right) optimization. Except H1 to H4, hydrogen atoms have been omitted for clarity.

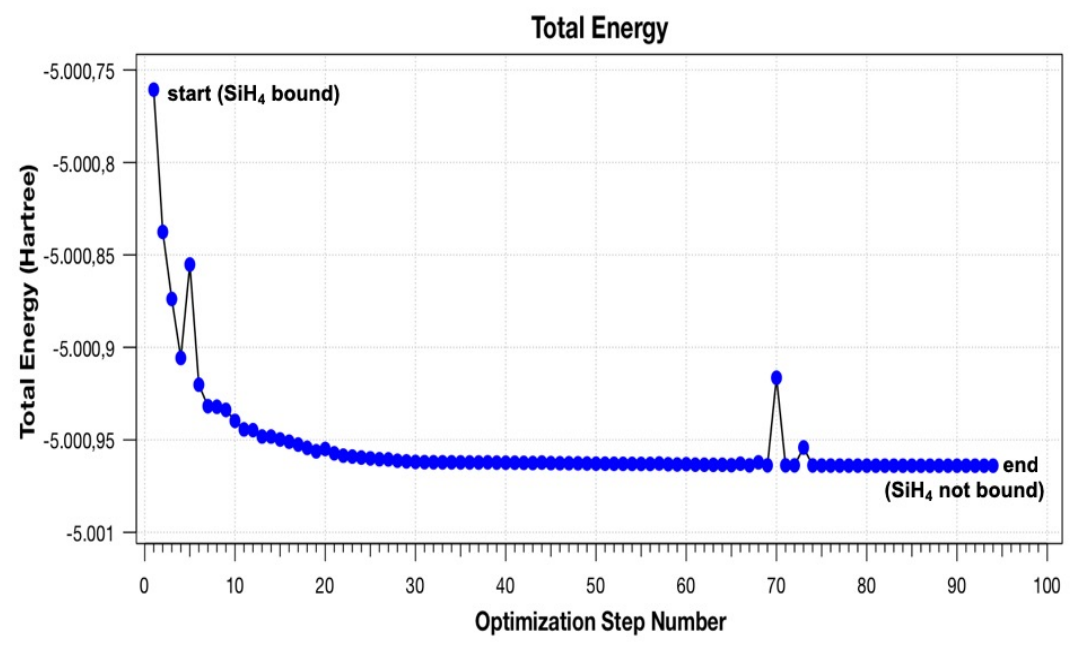

Figure S41. Geometry optimization of $\mathbf{2}[\mathbf{I}-\mathbf{1 b}]+\mathrm{SiH}_{4}$ at a M06L/6-31g $(\mathrm{d}, \mathrm{p})$ level of theory with added empirical dispersion (gd3). Total energy diagram (in Hartree) according to the optimization step coordinate.

Geometry optimization III

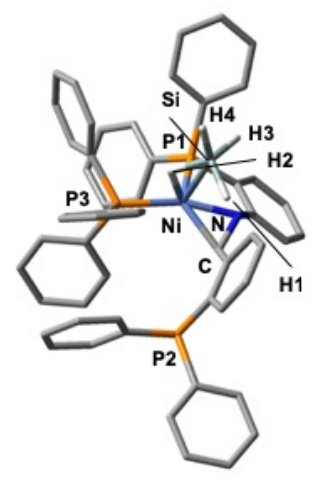

start optimization ( $\mathrm{SiH}_{4}$ bound)

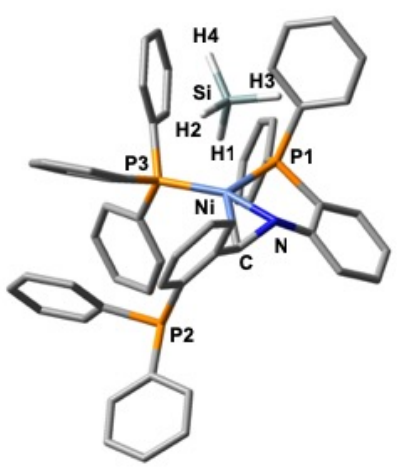

end optimization ( $\mathrm{SiH}_{4}$ not bound)

Figure S42. Geometry optimization of $\mathbf{2}[\mathbf{I}-\mathbf{1 b}]+\mathrm{SiH}_{4}$ at a M06L/6-31g $(\mathrm{d}, \mathrm{p})$ level of theory with added empirical dispersion (gd3). Structure before (left) and after (right) optimization. Except H1 to H4, hydrogen atoms have been omitted for clarity. 


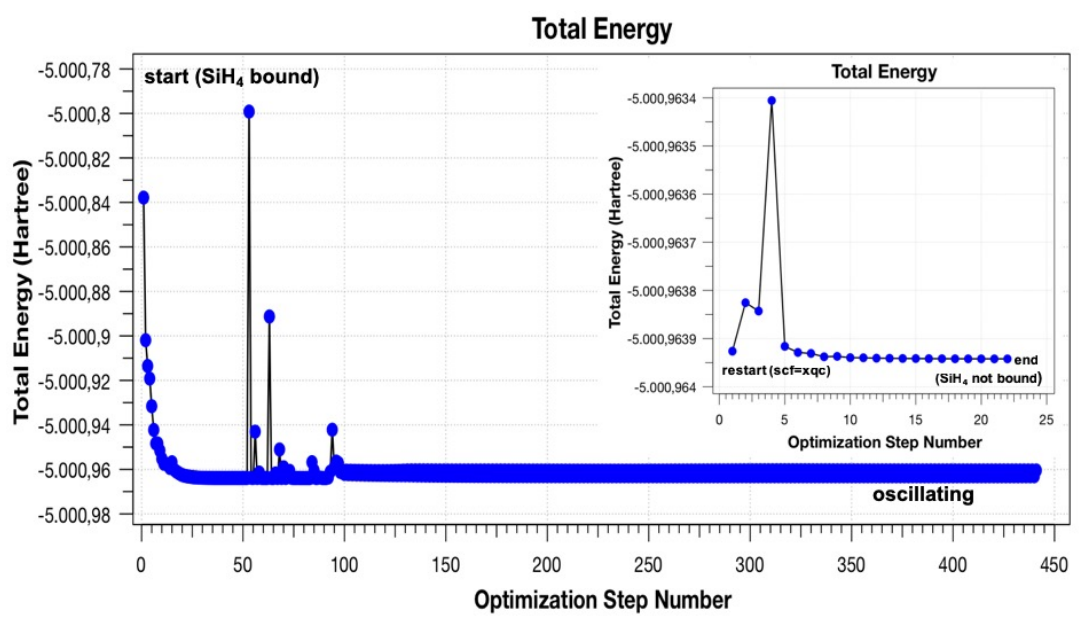

Figure S43. Geometry optimization of $2[\mathbf{I - 1 b}]+\mathrm{SiH}_{4}$ at a M06L/6-31g(d,p) level of theory with added empirical dispersion ( $g d 3)$. Total energy diagram (in Hartree) according to the optimization step coordinate. Due to geometry oscillation, the optimization was restated with additional keyword SCF=XQC.

\subsection{Other considered reaction mechanisms}

\subsubsection{Modified Chalk-Harrod pathway}

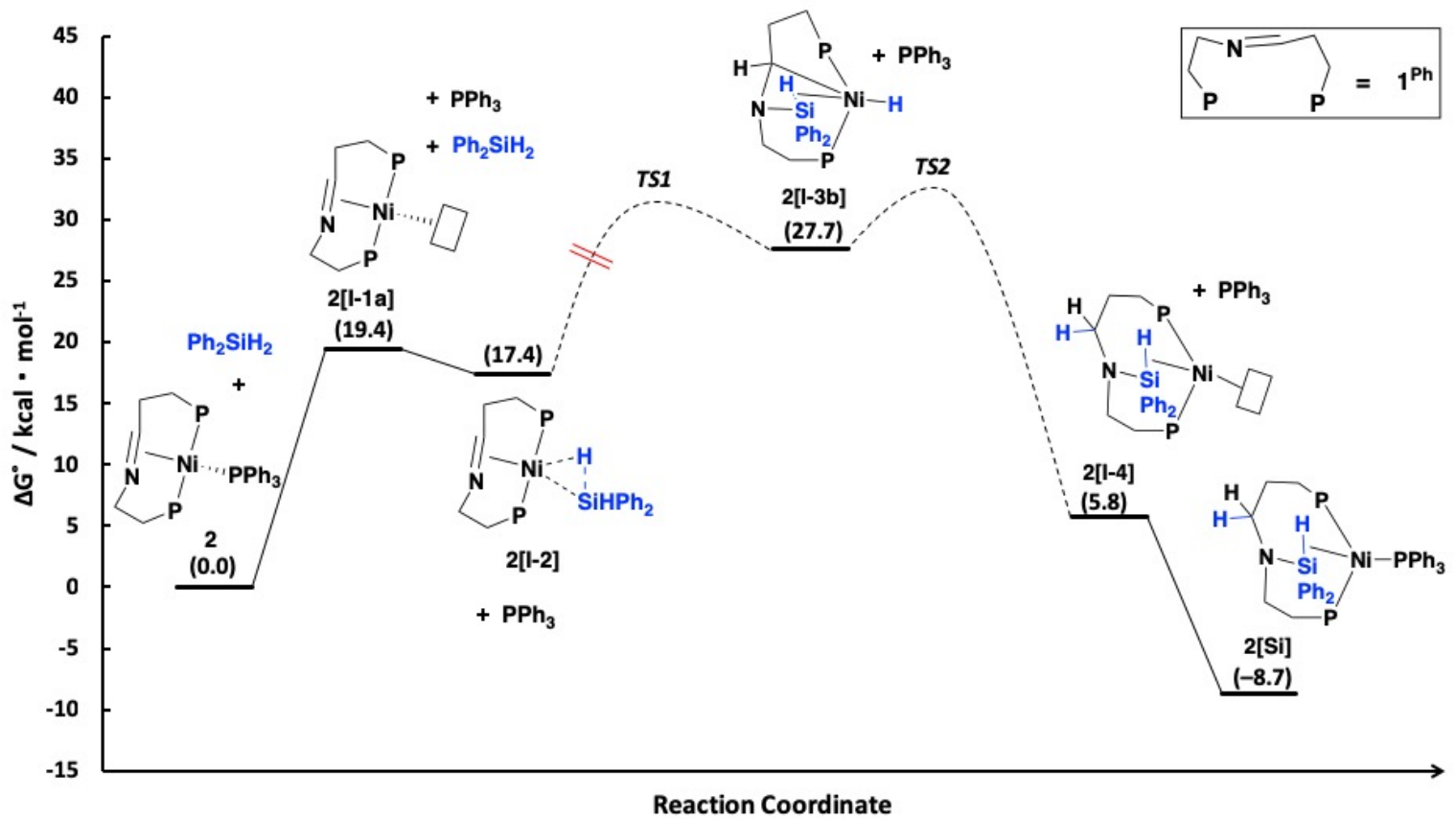

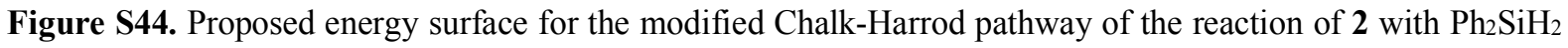
to form 2 [Si], calculated at a M06L//def2TZVP//M06L/6-31g(d,p) level of theory with the SMD benzene solvent model and added empirical dispersion. Dotted lines indicate that no transition states (TS1 and TS2) were located between the intermediates. The red double bar indicates that from a geometrical point of view the pathway from $\mathbf{2}[\mathbf{I}-\mathbf{2}]$ to $\mathbf{2}[\mathbf{I} 3-\mathbf{b}]$ is unfavorable and unlikely to happen. Energy values into parentheses are given in $\mathrm{kcal} / \mathrm{mol}$. $=$ free coordination site.

The structure of 2[I-2] (Figure S45, left) shows the nitrogen atom pointing away from the position of coordinated silicon (imine in trans configuration). The lone pair of $\mathrm{N}$ is therefore in a opposite direction from $\mathrm{Si}$ and prevent any interaction to form 2 [I-3b] (Figure S45, right). 


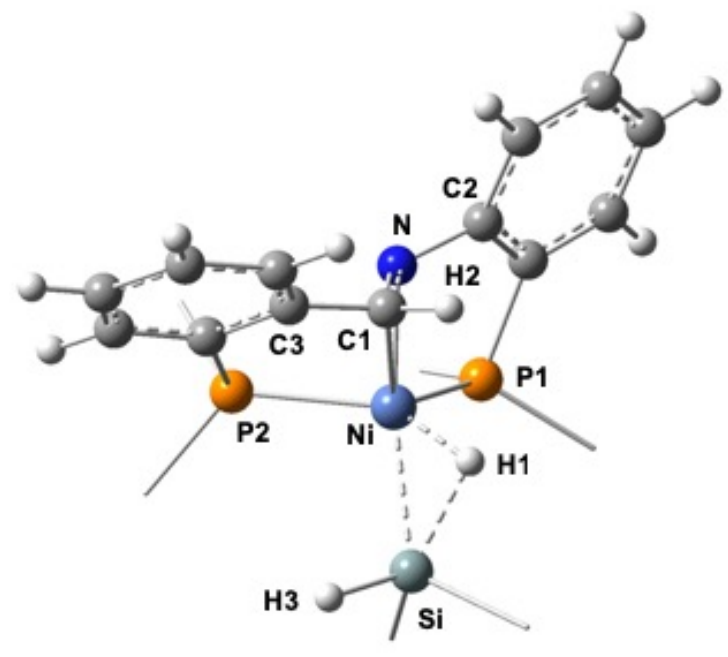

2[1-2]

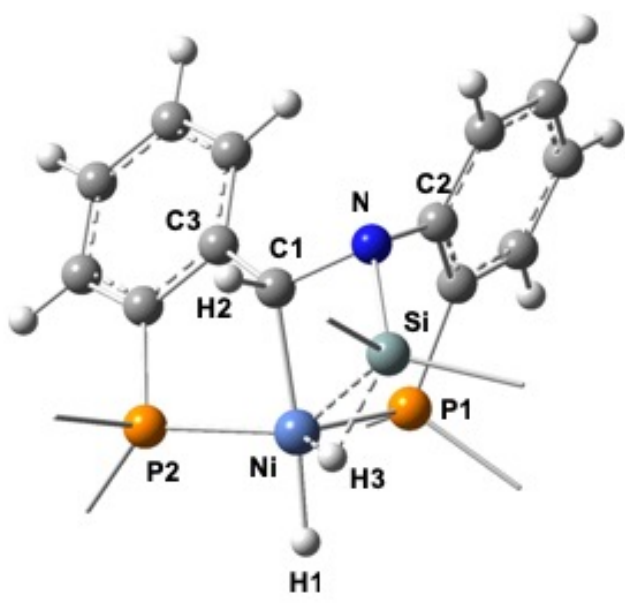

2[l-3b]

Figure S45. Optimized geometries of 2[I-2] and 2[I-3b] at a M06L/6-31g(d,p) level of theory with added empirical dispersion. Phenyl substituents on P1, P2 and Si are omitted for clarity.

\subsubsection{Direct addition pathway}

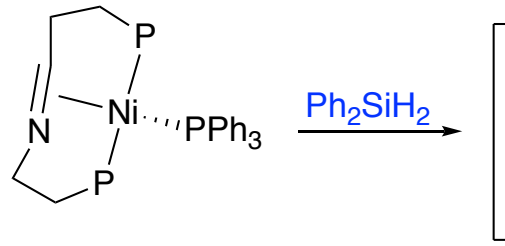

2<smiles></smiles>

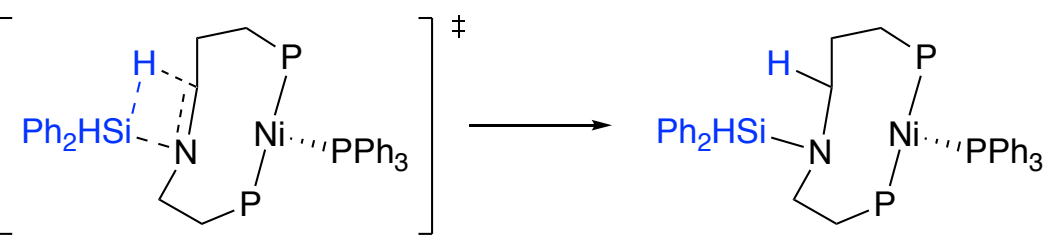

not located

2[I-DA]

Scheme S3. First step of direct addition mechanism. I-DA stands for direct addition intermediate.

The direct addition pathway (Scheme S3), does not involve the metal in the way the Chalk-Harrod and modified Chalk-Harrod mechanisms do. First, to check experimentally whether the metal is involved in the reaction, $\mathbf{1}^{\mathbf{P h}}$ was exposed to diphenylsilane without nickel. No reaction was observed. It indicates that the metal is involved in the hydrosilylation of $\mathbf{2}$. It would however be possible that the nickel center activates the imine moiety to favor the addition of $\mathrm{Ph}_{2} \mathrm{SiH}_{2}$. From the DFT optimized structure of 2 (Figure S46), it is revealed that the nitrogen lone-pair is pointing towards one of the phenyl rings on $\mathrm{P} 1$, preventing the approach of a silane from that side of the complex. From the top view, the bridging phenyl rings on $\mathrm{P} 1$ and $\mathrm{P} 2$ are hindering the approach of the silane since they are approximately parallel to the $\mathrm{N}-\mathrm{C} 1-\mathrm{Ni}$ plane. It is therefore unclear how the reaction could work through this mechanism. The problem with this mechanism lies in the trans geometry of the backbone. This geometry makes the imine less accessible than the cis like geometry which can be accessible upon reduction of the ligand backbone. One could therefore imagine a similar direct ionic pathway (Scheme S4) in which a hydride is added to $\mathrm{C} 1$ similar to Chalk-Harrod mechanism. The silylium amido intermediate 2[I-DA] ${ }^{-}$ however, has an energy of $93 \mathrm{kcal} / \mathrm{mol}$, too high to consider this pathway a viable option. 


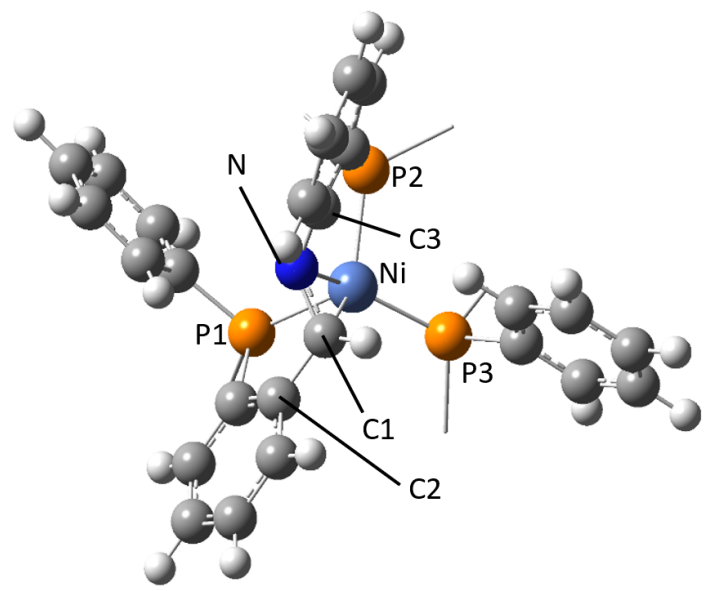

Figure S46. Optimized geometry of 2 at a M06L/6-31g(d,p) level of theory with added empirical dispersion. Zoom in the region of interest. Hydrogen atoms are shown in white.

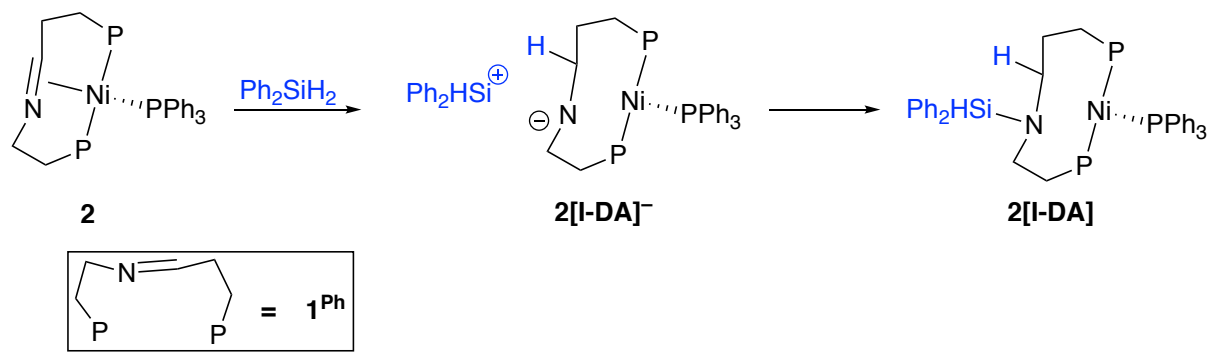

Scheme S4. Ionic variant of the direct addition mechanism.

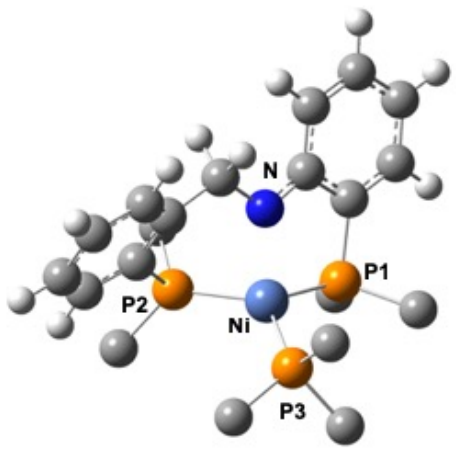

2[I-DA $]^{-}$

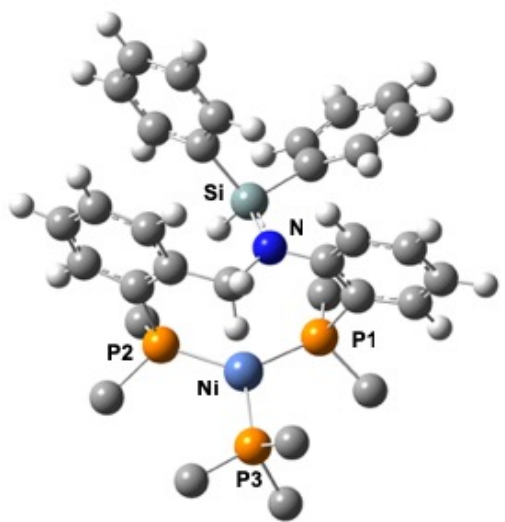

2[I-DA]

Figure S47. Optimized geometry (zoom in the region of interest) of 2[I-DA] ${ }^{-}$(left) and 2[I-DA] (right) at a M06L/6-31g(d,p) level of theory with added empirical dispersion. Carbon atoms are shown in grey and hydrogen in white. For clarity, only $\mathrm{C}_{\text {ipso }}$ from the phenyl substituents on phosphine groups are shown.

\subsubsection{Decoordination of one phosphine arm of the ligand}

Figure S48 shows the proposed calculated Chalk-Harrod energy surface for the reaction of 2 with $\mathrm{Ph}_{2} \mathrm{SiH}_{2}$ to form 2[Si]. The distinction with the other calculated Chalk-Harrod route from the main text is the decoordination of one P-arm from the ligand for the silyl transfer part (From 2[I-3a] to 2[Si]). Both evaluated routes, the concerted silyl transfer and P-arm recoordination (orange dotted line), and the stepwise mechanism (black dotted line) have intermediates (i.e. 2[I-4P1] and 2[I-4P2]) too high in energy (i.e. respectively $22.7 \mathrm{kcal} / \mathrm{mol}$ and $37.8 \mathrm{kcal} / \mathrm{mol}$ ) to correlate with the experimental observations. 


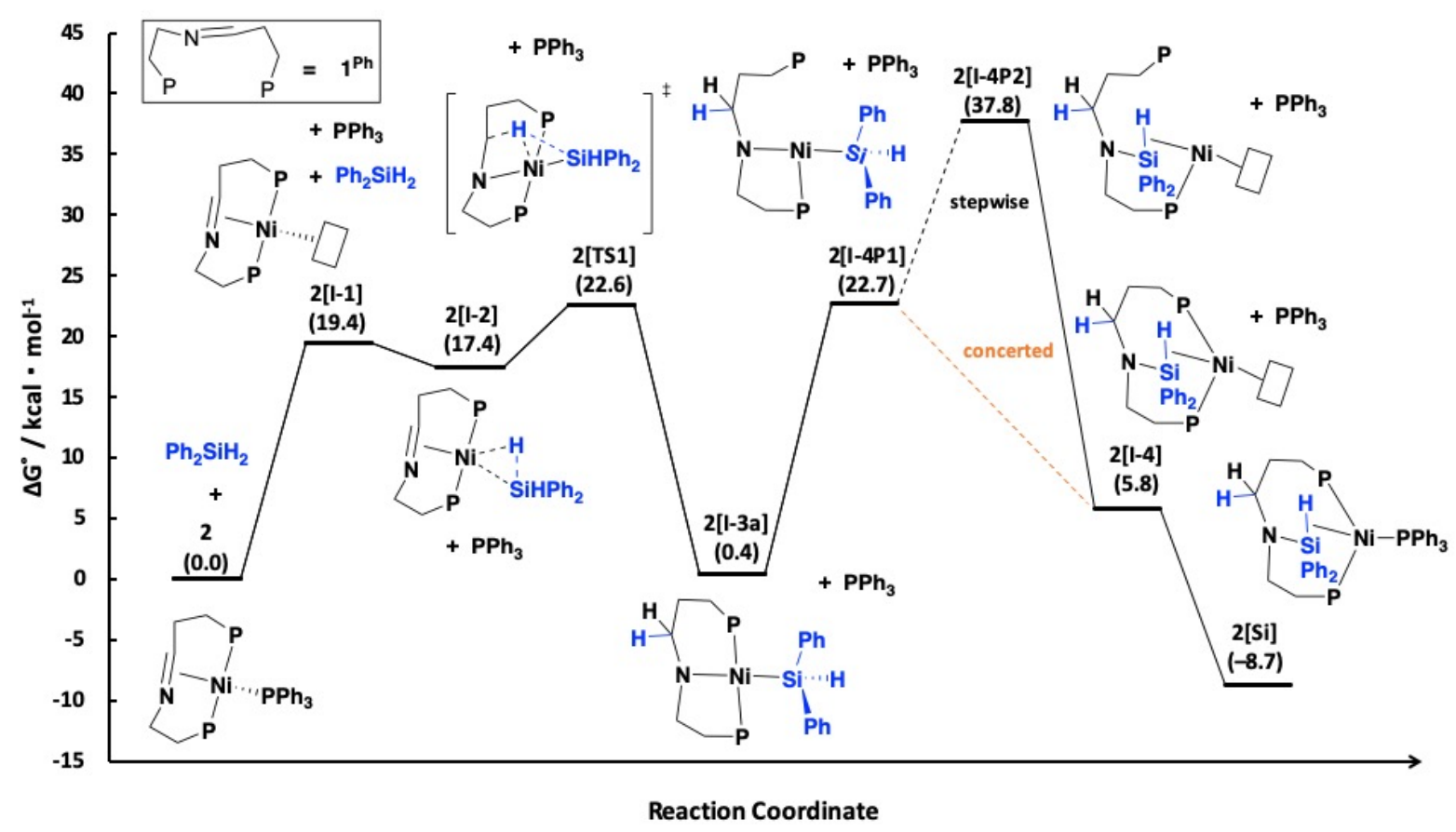

Figure S48. Proposed energy surface for the Chalk-Harrod pathway (with decoordination of one P-arm from the ligand) of the reaction of 2 with $\mathrm{Ph}_{2} \mathrm{SiH}_{2}$ to form 2 [Si], calculated at a M06L//def2TZVP//M06L/6-31g(d,p) level of theory with the SMD benzene solvent model and added empirical dispersion. Dotted lines indicate that the transition state between the intermediates has not been calculated and a higher transition is expected. Values into parentheses are given in $\mathrm{kcal} / \mathrm{mol}$. represents a free coordination site.

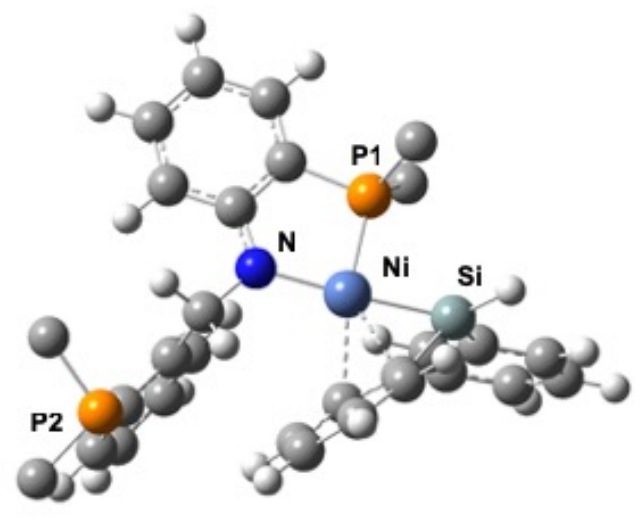

2[I-4P1]

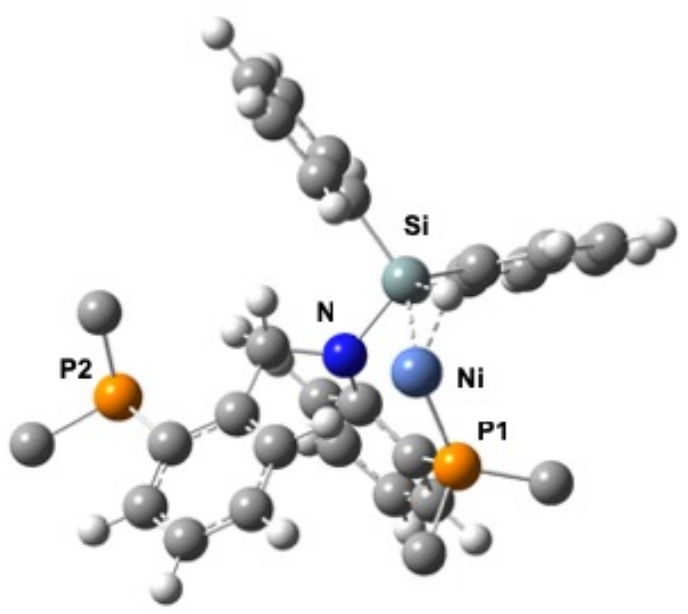

4[1-4P2]

Figure S49. Optimized geometries of 2[I-4P1] (left) and 2[I-4P2] (right) at a M06L/6-31g(d,p) level of theory with added empirical dispersion. In 2[I-4P1], one phenyl substituent from Si is interacting (dotted line) with $\mathrm{Ni}$. Carbon atoms are shown in grey and hydrogen in white. For clarity, only $\mathrm{C}_{\mathrm{ipso}}$ from the phenyl substituents on phosphine groups are shown. 


\subsection{Full proposed pathway}

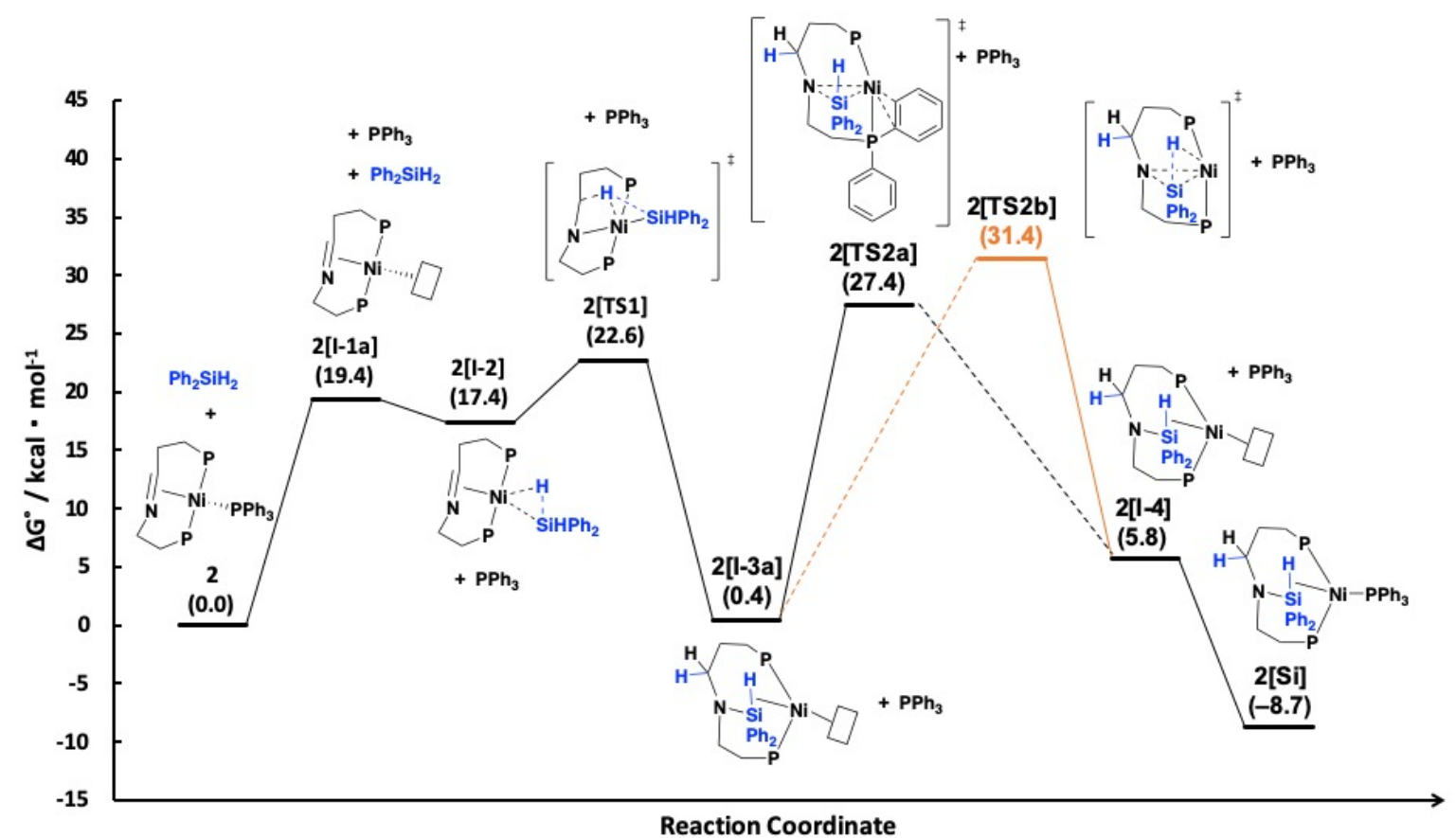

Figure S50. Proposed energy surface for the Chalk-Harrod pathway of the reaction of $\mathbf{2}$ with $\mathrm{Ph}_{2} \mathrm{SiH}_{2}$ to form $2[\mathrm{Si}$, calculated at a M06L//def2TZVP//M06L/6-31g(d,p) level of theory with the SMD benzene solvent model and added empirical dispersion. Dotted lines indicate that the transition state is not connected with the intermediate. Orange line indicates a $2^{\text {nd }}$ possible route from 2 [I-3a] to 2 [I-4a] with a different transition state. represents a free coordination site.

\subsection{Optimized structures}

A text file of all computed molecule Cartesian coordinates in a format for convenient visualization is also provided (DFT.xyz).

\begin{tabular}{|c|c|c|c|}
\hline $\begin{array}{l}\text { Cor } \\
\text { Cha } \\
\text { Mu } \\
\text { Lov } \\
\text { Ene }\end{array}$ & $\begin{array}{l}: \mathrm{PPh}_{3} \\
\text { y: } 1 \\
\text { quency: } 18.6 \\
\text { a36.209329 } \mathrm{H}\end{array}$ & $\begin{array}{l}8 \mathrm{~cm}^{-1} \\
\text { artree }\end{array}$ & \\
\hline $\mathrm{P}$ & 0.02651700 & -0.04723800 & 1.31589500 \\
\hline $\mathrm{C}$ & -1.61122600 & -0.26444300 & 0.51131900 \\
\hline $\mathrm{C}$ & 0.61318000 & 1.51082000 & 0.53788100 \\
\hline $\mathrm{C}$ & 1.03976100 & -1.30069300 & 0.43343800 \\
\hline $\mathrm{C}$ & -1.85092000 & -1.11462100 & -0.57427800 \\
\hline $\mathrm{C}$ & 0.00131500 & 2.12217400 & -0.56291600 \\
\hline $\mathrm{C}$ & 1.83741000 & -1.02386500 & -0.68301700 \\
\hline $\mathrm{C}$ & -2.68367700 & 0.47042200 & 1.03761000 \\
\hline $\mathrm{C}$ & 1.75551200 & 2.10829600 & 1.08865600 \\
\hline $\mathrm{C}$ & 0.99967300 & -2.61489800 & 0.92062400 \\
\hline $\mathrm{C}$ & -3.12837200 & -1.22248700 & -1.11962800 \\
\hline $\mathrm{C}$ & 0.52246300 & 3.29720100 & -1.09919200 \\
\hline $\mathrm{C}$ & 2.57076600 & -2.03647000 & -1.29685600 \\
\hline $\mathrm{C}$ & -3.95485400 & 0.37348900 & 0.48310500 \\
\hline $\mathrm{C}$ & 2.28312500 & 3.27422800 & 0.54441100 \\
\hline $\mathrm{C}$ & 1.72066300 & -3.62823100 & 0.29832500 \\
\hline
\end{tabular}

$\begin{array}{rrr}-4.18155500 & -0.47770000 & -0.59672300 \\ 1.66485700 & 3.87388300 & -0.55061600 \\ 2.51196400 & -3.34002400 & -0.81167000 \\ -1.03350300 & -1.69345600 & -0.99746800 \\ -0.88567000 & 1.67376200 & -1.00429800 \\ 1.88262800 & -0.01087700 & -1.07571800 \\ -2.51411500 & 1.12784500 & 1.88854500 \\ 2.23434600 & 1.64904800 & 1.95154400 \\ 0.39231100 & -2.84165900 & 1.79503500 \\ -3.29828400 & -1.88823700 & -1.96168600 \\ 0.03583000 & 3.76040300 & -1.95346900 \\ 3.18657300 & -1.80526700 & -2.16199700 \\ -4.77210700 & 0.95553300 & 0.90028400 \\ 3.17231100 & 3.72070400 & 0.98105300 \\ 1.67286300 & -4.64216900 & 0.68604800 \\ -5.17620300 & -0.56257900 & -1.02539900 \\ 2.06978200 & 4.78973800 & -0.97202700 \\ 3.08383200 & -4.12813500 & -1.29351700\end{array}$

Compound: $\mathrm{Ph}_{2} \mathrm{SiH}_{2}$ Charge: 0 
Multiplicity: 1

Lowest Frequency: $20.28 \mathrm{~cm}^{-1}$

Energy: -753.935814 Hartree

$\begin{array}{lrrr}\mathrm{Si} & -0.00013500 & 1.58789200 & 0.00054300 \\ \mathrm{H} & -0.11377100 & 2.46892400 & 1.19195900 \\ \mathrm{H} & 0.11330600 & 2.46971600 & -1.19030300 \\ \mathrm{C} & -1.53443500 & 0.51231800 & -0.05838500 \\ \mathrm{C} & -1.53747300 & -0.70357500 & -0.75994200 \\ \mathrm{C} & -2.71805300 & 0.89808200 & 0.58846900 \\ \mathrm{C} & -2.67840000 & -1.49825100 & -0.82027800 \\ \mathrm{H} & -0.62759600 & -1.03880500 & -1.25654600 \\ \mathrm{C} & -3.86238000 & 0.10738300 & 0.53159800 \\ \mathrm{H} & -2.74353100 & 1.82895300 & 1.15281900 \\ \mathrm{C} & -3.84384700 & -1.09232600 & -0.17473600 \\ \mathrm{H} & -2.65828500 & -2.43638100 & -1.36882800 \\ \mathrm{H} & -4.76740200 & 0.42415800 & 1.04338500 \\ \mathrm{H} & -4.73472300 & -1.71309000 & -0.21740800 \\ \mathrm{C} & 1.53439000 & 0.51263800 & 0.05878300 \\ \mathrm{C} & 2.71711700 & 0.89768000 & -0.59011300 \\ \mathrm{C} & 1.53841300 & -0.70242700 & 0.76177800 \\ \mathrm{C} & 3.86154700 & 0.10707200 & -0.53385200 \\ \mathrm{H} & 2.74179700 & 1.82790200 & -1.15555800 \\ \mathrm{C} & 2.67944400 & -1.49698300 & 0.82154600 \\ \mathrm{H} & 0.62919000 & -1.03710700 & 1.25995800 \\ \mathrm{C} & 3.84400800 & -1.09178900 & 0.17393400 \\ \mathrm{H} & 4.76585700 & 0.42325500 & -1.04725600 \\ \mathrm{H} & 2.66010600 & -2.43446000 & 1.37123500 \\ \mathrm{H} & 4.73496000 & -1.71247200 & 0.21614100\end{array}$

Compound: $\mathrm{PhMeSiH}_{2}$

Charge: 0

Multiplicity: 1

Lowest Frequency: $38.05 \mathrm{~cm}^{-1}$

Energy: -562.222229 Hartree

$\begin{array}{lrrr}\mathrm{Si} & -1.89518200 & -0.38704000 & -0.44387900 \\ \mathrm{H} & -2.17551700 & -1.84098100 & -0.33219300 \\ \mathrm{H} & -2.29726800 & 0.06487600 & -1.80122800 \\ \mathrm{C} & -0.05014500 & -0.14805900 & -0.20506300 \\ \mathrm{C} & 0.54454200 & 1.12063700 & -0.30153800 \\ \mathrm{C} & 0.78260500 & -1.23617200 & 0.09367100 \\ \mathrm{C} & 1.91100900 & 1.29540700 & -0.10891800 \\ \mathrm{H} & -0.06975100 & 1.98973200 & -0.53524000 \\ \mathrm{C} & 2.15119500 & -1.06848600 & 0.28888800 \\ \mathrm{H} & 0.35334800 & -2.23338100 & 0.17521100 \\ \mathrm{C} & 2.71760700 & 0.19875400 & 0.18746400 \\ \mathrm{H} & 2.34873100 & 2.28684900 & -0.19151400 \\ \mathrm{H} & 2.77607200 & -1.92701600 & 0.52025500 \\ \mathrm{H} & 3.78545200 & 0.33330500 & 0.33797900 \\ \mathrm{C} & -2.87922000 & 0.57284600 & 0.83370500 \\ \mathrm{H} & -2.66141200 & 1.64315800 & 0.77431200 \\ \mathrm{H} & -3.95549100 & 0.44717200 & 0.68936400 \\ \mathrm{H} & -2.63718300 & 0.24527900 & 1.84811000\end{array}$

Compound: $\mathrm{Ph}_{2} \mathrm{SiH}^{+}$

Charge: 1

Multiplicity: 1

\section{Lowest Frequency: $49.69 \mathrm{~cm}^{-1}$}

Energy: -753.071197 Hartree

$\begin{array}{lrrr}\mathrm{Si} & -0.00001200 & 1.16551000 & 0.00015700 \\ \mathrm{H} & -0.00028300 & 2.63387800 & 0.00009200 \\ \mathrm{C} & 1.60986100 & 0.36549500 & 0.02581300 \\ \mathrm{C} & 1.78025100 & -1.01075400 & 0.30827300 \\ \mathrm{C} & 2.75334300 & 1.16003500 & -0.23347700 \\ \mathrm{C} & 3.04676400 & -1.56877900 & 0.31745500 \\ \mathrm{H} & 0.92288600 & -1.63199800 & 0.55106000 \\ \mathrm{C} & 4.01581500 & 0.58839800 & -0.23399800 \\ \mathrm{H} & 2.64696300 & 2.22268200 & -0.43881000 \\ \mathrm{C} & 4.16073000 & -0.77225600 & 0.03967400 \\ \mathrm{H} & 3.17442800 & -2.62183900 & 0.54490700 \\ \mathrm{H} & 4.88786100 & 1.19897500 & -0.44190600 \\ \mathrm{H} & 5.15186300 & -1.21580700 & 0.04602300 \\ \mathrm{C} & -1.60978000 & 0.36530800 & -0.02580900 \\ \mathrm{C} & -2.75319500 & 1.16001100 & 0.23332300 \\ \mathrm{C} & -1.78030700 & -1.01091800 & -0.30821700 \\ \mathrm{C} & -4.01574100 & 0.58852600 & 0.23380200 \\ \mathrm{H} & -2.64670200 & 2.22266100 & 0.43859400 \\ \mathrm{C} & -3.04687900 & -1.56879900 & -0.31740300 \\ \mathrm{H} & -0.92299000 & -1.63225100 & -0.55094000 \\ \mathrm{C} & -4.16078200 & -0.77213200 & -0.03976000 \\ \mathrm{H} & -4.88773300 & 1.19922000 & 0.44159500 \\ \mathrm{H} & -3.17465800 & -2.62186800 & -0.54474900 \\ \mathrm{H} & -5.15195600 & -1.21559300 & -0.04611700 \\ & & & \\ & & & \\ & & & \end{array}$

Compound: 2

Charge: 0

Multiplicity: 1

Lowest Frequency: $19.29 \mathrm{~cm}^{-1}$

Energy: -4709.101422 Hartree

$\begin{array}{cccc}\mathrm{Ni} & 0.00416800 & 0.00190500 & 0.60714700 \\ \mathrm{P} & 0.96970700 & 1.85290400 & -0.00947000 \\ \mathrm{P} & -2.21765100 & -0.15651400 & 0.06529600 \\ \mathrm{P} & 1.23776900 & -1.60365900 & -0.08838700 \\ \mathrm{~N} & -0.57395600 & 0.94012300 & 2.15843200 \\ \mathrm{C} & 1.10624600 & 2.58370300 & 1.65521100 \\ \mathrm{C} & 1.93791100 & 3.63234700 & 2.04885100 \\ \mathrm{C} & 2.03490600 & 3.98550700 & 3.39230800 \\ \mathrm{C} & 1.29358100 & 3.27963000 & 4.34258300 \\ \mathrm{C} & 0.44499100 & 2.24534300 & 3.96615400 \\ \mathrm{C} & 0.33484400 & 1.88986700 & 2.61402000 \\ \mathrm{C} & -0.49398500 & -0.38321000 & 2.51010400 \\ \mathrm{C} & -1.75794500 & -1.14265400 & 2.61158600 \\ \mathrm{C} & -1.99855300 & -1.99008300 & 3.69757900 \\ \mathrm{C} & -3.17217500 & -2.73484300 & 3.77732300 \\ \mathrm{C} & -4.13091000 & -2.63423600 & 2.77270600 \\ \mathrm{C} & -3.89966000 & -1.80212100 & 1.67959600 \\ \mathrm{C} & -2.71812100 & -1.06855100 & 1.57773600 \\ \mathrm{C} & 0.08875100 & 3.07039700 & -1.05134500 \\ \mathrm{C} & -0.25700000 & 2.68912200 & -2.35591700 \\ \mathrm{C} & -0.92636900 & 3.56858200 & -3.19944400 \\ \mathrm{C} & -1.29178600 & 4.83166400 & -2.73893100 \\ \mathrm{C} & -0.98863600 & 5.20425300 & -1.43220500 \\ \mathrm{C} & -0.29674900 & 4.33346000 & -0.59399400\end{array}$




\begin{tabular}{|c|c|c|c|c|c|c|c|}
\hline $\mathrm{C}$ & 2.68707000 & 1.91055600 & -0.64664400 & $\mathrm{H}$ & -4.08988600 & 3.97849400 & -1.88282500 \\
\hline $\mathrm{C}$ & 3.70427300 & 1.45162000 & 0.20206800 & $\mathrm{H}$ & -3.08104500 & 1.73290500 & -1.97867100 \\
\hline $\mathrm{C}$ & 5.01731900 & 1.35566100 & -0.24041800 & $\mathrm{H}$ & -1.48546600 & -2.33970300 & -1.63655800 \\
\hline $\mathrm{C}$ & 5.34227800 & 1.72174500 & -1.54549800 & $\mathrm{H}$ & -2.64802600 & -3.64684100 & -3.37990500 \\
\hline $\mathrm{C}$ & 4.34226900 & 2.18621400 & -2.39448900 & $\mathrm{H}$ & -4.99184200 & -3.08159900 & -4.00173500 \\
\hline $\mathrm{C}$ & 3.02456000 & 2.27964700 & -1.95233100 & $\mathrm{H}$ & -6.15463600 & -1.21778700 & -2.84486700 \\
\hline $\mathrm{C}$ & -3.08282800 & 1.44670300 & 0.16168400 & $\mathrm{H}$ & -4.98856300 & 0.08210400 & -1.09770200 \\
\hline $\mathrm{C}$ & -3.39697800 & 2.03444100 & 1.39262200 & $\mathrm{H}$ & 4.03071800 & -1.63907900 & -1.30581100 \\
\hline $\mathrm{C}$ & -3.95490900 & 3.30881700 & 1.44330700 & $\mathrm{H}$ & 4.80686900 & -1.11131700 & -3.58472000 \\
\hline $\mathrm{C}$ & -4.21242500 & 4.01165100 & 0.26976800 & $\mathrm{H}$ & 3.18459500 & -0.44703500 & -5.34255100 \\
\hline $\mathrm{C}$ & -3.90220100 & 3.43526800 & -0.96013200 & $\mathrm{H}$ & 0.76480200 & -0.28012200 & -4.78381600 \\
\hline $\mathrm{C}$ & -3.33273500 & 2.16880300 & -1.01341600 & $\mathrm{H}$ & -0.01322800 & -0.77493200 & -2.48856100 \\
\hline $\mathrm{C}$ & -3.15091900 & -1.03847200 & -1.24542000 & $\mathrm{H}$ & 2.42768500 & -0.42080400 & 2.30364000 \\
\hline $\mathrm{C}$ & -2.50977800 & -2.09391700 & -1.90372900 & $\mathrm{H}$ & 4.39135000 & -1.01801500 & 3.69836100 \\
\hline $\mathrm{C}$ & -3.16688200 & -2.82995800 & -2.88479300 & $\mathrm{H}$ & 5.75300500 & -3.01761600 & 3.13614600 \\
\hline $\mathrm{C}$ & -4.47807400 & -2.51451900 & -3.23012900 & $\mathrm{H}$ & 5.12879600 & -4.43010800 & 1.19148800 \\
\hline $\mathrm{C}$ & -5.12938700 & -1.46600900 & -2.58301400 & $\mathrm{H}$ & 3.16281800 & -3.83830700 & -0.18903700 \\
\hline $\mathrm{C}$ & -4.47373600 & -0.73521200 & -1.59707400 & $\mathrm{H}$ & -0.40554500 & -3.16190000 & 1.64558800 \\
\hline $\mathrm{C}$ & 1.95110300 & -1.27186500 & -1.74352000 & $\mathrm{H}$ & -1.65076400 & -5.27847900 & 1.41770000 \\
\hline $\mathrm{C}$ & 3.30718500 & -1.35660600 & -2.06627100 & $\mathrm{H}$ & -1.50428400 & -6.59003900 & -0.69448700 \\
\hline $\mathrm{C}$ & 3.74567000 & -1.05728000 & -3.35529200 & $\mathrm{H}$ & -0.07079900 & -5.77556000 & -2.54954200 \\
\hline $\mathrm{C}$ & 2.83812400 & -0.67898100 & -4.33896900 & $\mathrm{H}$ & 1.16561700 & -3.64944100 & -2.32845100 \\
\hline $\mathrm{C}$ & 1.48293000 & -0.58351300 & -4.02582600 & & & & \\
\hline $\mathrm{C}$ & 1.04533200 & -0.86810100 & -2.73773000 & \multicolumn{4}{|c|}{ Compound: $2[\mathrm{Si}]$} \\
\hline $\mathrm{C}$ & 2.67918700 & -2.07288400 & 0.94944700 & \multicolumn{4}{|c|}{ Charge: 0} \\
\hline $\mathrm{C}$ & 3.02918500 & -1.29702900 & 2.05807500 & \multicolumn{4}{|c|}{ Multiplicity: 1} \\
\hline $\mathrm{C}$ & 4.13158100 & -1.63278700 & 2.84087700 & \multicolumn{4}{|c|}{ Lowest Frequency: $23.07 \mathrm{~cm}^{-1}$} \\
\hline $\mathrm{C}$ & 4.89300400 & -2.75472400 & 2.52634200 & \multicolumn{4}{|c|}{ Energy: -5463.095652 Hartree } \\
\hline $\mathrm{C}$ & 4.54361600 & -3.54731900 & 1.43428900 & & & & \\
\hline $\mathrm{C}$ & 3.44098200 & -3.21176200 & 0.65689500 & $\mathrm{Ni}$ & -0.02774000 & 0.09319800 & -0.17888600 \\
\hline $\mathrm{C}$ & 0.46221100 & -3.25317500 & -0.32520000 & $\mathrm{P}$ & -1.66432000 & -0.97573100 & 0.85892200 \\
\hline $\mathrm{C}$ & -0.32764100 & -3.73852100 & 0.72579800 & $\mathrm{P}$ & 1.67982600 & 0.52554600 & 1.13661300 \\
\hline $\mathrm{C}$ & -1.02861800 & -4.93076800 & 0.59686900 & $\mathrm{P}$ & -0.91366400 & 1.86339900 & -1.22323500 \\
\hline $\mathrm{C}$ & -0.94640200 & -5.66398000 & -0.58613800 & $\mathrm{Si}$ & 1.13845600 & -1.71701700 & -0.80612900 \\
\hline $\mathrm{C}$ & -0.14687800 & -5.20358600 & -1.62807200 & $\mathrm{~N}$ & 1.28217400 & -2.63746400 & 0.72015600 \\
\hline $\mathrm{C}$ & 0.55559600 & -4.00608100 & -1.50129700 & $\mathrm{C}$ & -1.31992400 & -1.92358700 & 2.41297100 \\
\hline $\mathrm{H}$ & 2.54050400 & 4.14527400 & 1.30078600 & $\mathrm{C}$ & -0.50106900 & -3.07380300 & 2.39445400 \\
\hline $\mathrm{H}$ & 2.69460700 & 4.79136200 & 3.69996400 & $\mathrm{C}$ & -0.30505700 & -3.78675500 & 3.57855700 \\
\hline $\mathrm{H}$ & 1.37858500 & 3.54119900 & 5.39452600 & $\mathrm{C}$ & -0.87904800 & -3.38639400 & 4.78073200 \\
\hline $\mathrm{H}$ & -0.14705600 & 1.70926900 & 4.70383900 & $\mathrm{C}$ & -1.67417700 & -2.24786200 & 4.80402700 \\
\hline $\mathrm{H}$ & 0.30376500 & -0.69742100 & 3.19703200 & $\mathrm{C}$ & -1.89976700 & -1.53731200 & 3.62875300 \\
\hline $\mathrm{H}$ & -1.24891900 & -2.06195600 & 4.48377200 & $\mathrm{C}$ & 0.20759100 & -3.53924300 & 1.14734100 \\
\hline $\mathrm{H}$ & -3.33736700 & -3.39424600 & 4.62562300 & $\mathrm{C}$ & -3.03521800 & 0.11470300 & 1.42966900 \\
\hline $\mathrm{H}$ & -5.04695200 & -3.21578000 & 2.82798900 & $\mathrm{C}$ & -2.68845700 & 1.36000100 & 1.96579700 \\
\hline $\mathrm{H}$ & -4.63049500 & -1.75609100 & 0.87492200 & $\mathrm{C}$ & -3.66436200 & 2.26689400 & 2.36526600 \\
\hline $\mathrm{H}$ & 0.00518500 & 1.68962200 & -2.70445700 & $\mathrm{C}$ & -5.01176000 & 1.94216800 & 2.22470400 \\
\hline $\mathrm{H}$ & -1.17551900 & 3.26243200 & -4.21249200 & $\mathrm{C}$ & -5.37042300 & 0.69897600 & 1.70737500 \\
\hline $\mathrm{H}$ & -1.82702000 & 5.51647700 & -3.39163800 & $\mathrm{C}$ & -4.39162300 & -0.21205700 & 1.31794500 \\
\hline $\mathrm{H}$ & -1.29443100 & 6.17853500 & -1.05940600 & $\mathrm{C}$ & -2.60865900 & -2.25607800 & -0.07353100 \\
\hline $\mathrm{H}$ & -0.06528800 & 4.63050200 & 0.42627800 & $\mathrm{C}$ & -3.26796100 & -3.32588100 & 0.55120500 \\
\hline $\mathrm{H}$ & 3.45983500 & 1.18259900 & 1.22580900 & $\mathrm{C}$ & -3.98198100 & -4.25289400 & -0.20011000 \\
\hline $\mathrm{H}$ & 5.78577800 & 0.99276700 & 0.43810300 & $\mathrm{C}$ & -4.05983800 & -4.12140200 & -1.58611700 \\
\hline $\mathrm{H}$ & 6.36796200 & 1.64691300 & -1.89688600 & $\mathrm{C}$ & -3.42201500 & -3.05670300 & -2.21296200 \\
\hline $\mathrm{H}$ & 4.58376300 & 2.47394900 & -3.41481000 & $\mathrm{C}$ & -2.70063600 & -2.13371500 & -1.46085800 \\
\hline $\mathrm{H}$ & 2.25887100 & 2.64611700 & -2.63121600 & $\mathrm{C}$ & 2.50182600 & -0.88661700 & 1.98046500 \\
\hline $\mathrm{H}$ & -3.19456200 & 1.48847800 & 2.30923900 & $\mathrm{C}$ & 2.17724000 & -2.23942000 & 1.72501200 \\
\hline $\mathrm{H}$ & -4.19382000 & 3.75104300 & 2.40708000 & $\mathrm{C}$ & 2.77896700 & -3.23291800 & 2.52230700 \\
\hline $\mathrm{H}$ & -4.65054800 & 5.00543300 & 0.31220000 & $\mathrm{C}$ & 3.68411400 & -2.91937600 & 3.51973200 \\
\hline
\end{tabular}




\begin{tabular}{|c|c|c|c|}
\hline $\mathrm{C}$ & 4.01752700 & -1.58694400 & 3.76635500 \\
\hline $\mathrm{C}$ & 3.42128800 & -0.59650000 & 3.00357400 \\
\hline $\mathrm{C}$ & 3.07420900 & 1.45013100 & 0.37644300 \\
\hline $\mathrm{C}$ & 2.74781900 & 2.60627500 & -0.34395700 \\
\hline $\mathrm{C}$ & 3.72719300 & 3.35051500 & -0.99103000 \\
\hline $\mathrm{C}$ & 5.05943500 & 2.94576200 & -0.92682200 \\
\hline $\mathrm{C}$ & 5.39653900 & 1.80112500 & -0.21055700 \\
\hline $\mathrm{C}$ & 4.41332600 & 1.05543400 & 0.43475600 \\
\hline $\mathrm{C}$ & 1.34664300 & 1.57741500 & 2.62056400 \\
\hline $\mathrm{C}$ & 1.92815800 & 2.82889800 & 2.85338900 \\
\hline $\mathrm{C}$ & 1.55030200 & 3.58858200 & 3.96052000 \\
\hline $\mathrm{C}$ & 0.59364100 & 3.11118200 & 4.85179700 \\
\hline $\mathrm{C}$ & 0.02450300 & 1.85610100 & 4.63921100 \\
\hline $\mathrm{C}$ & 0.40165200 & 1.09975500 & 3.53657100 \\
\hline $\mathrm{C}$ & 0.48180800 & -2.96759600 & -2.06661800 \\
\hline $\mathrm{C}$ & 0.66555700 & -4.35232000 & -1.94161300 \\
\hline $\mathrm{C}$ & 0.27285200 & -5.23152800 & -2.94728800 \\
\hline $\mathrm{C}$ & -0.29476300 & -4.74090100 & -4.12061400 \\
\hline $\mathrm{C}$ & -0.46231800 & -3.36727100 & -4.28142000 \\
\hline $\mathrm{C}$ & -0.08170300 & -2.50051800 & -3.26282300 \\
\hline $\mathrm{C}$ & 0.15922700 & 2.65300400 & -2.50623800 \\
\hline $\mathrm{C}$ & 0.33332300 & 4.04037300 & -2.59864000 \\
\hline $\mathrm{C}$ & 1.20245800 & 4.58939200 & -3.53913600 \\
\hline $\mathrm{C}$ & 1.91314500 & 3.76868800 & -4.41000500 \\
\hline $\mathrm{C}$ & 1.74727400 & 2.38885100 & -4.33332500 \\
\hline $\mathrm{C}$ & 0.88441400 & 1.84217600 & -3.38933900 \\
\hline $\mathrm{C}$ & -2.37287200 & 1.33124100 & -2.20688300 \\
\hline $\mathrm{C}$ & -3.63064700 & 1.25114900 & -1.59277700 \\
\hline $\mathrm{C}$ & -4.70592000 & 0.65816100 & -2.24693600 \\
\hline $\mathrm{C}$ & -4.54844400 & 0.12938600 & -3.52553700 \\
\hline $\mathrm{C}$ & -3.30816100 & 0.21568600 & -4.15198700 \\
\hline $\mathrm{C}$ & -2.23258500 & 0.81328400 & -3.50116800 \\
\hline $\mathrm{C}$ & -1.51618900 & 3.35493100 & -0.33928400 \\
\hline $\mathrm{C}$ & -0.79293800 & 3.74699800 & 0.79171800 \\
\hline $\mathrm{C}$ & -1.13481000 & 4.89124700 & 1.50341800 \\
\hline $\mathrm{C}$ & -2.22287100 & 5.65955200 & 1.09536700 \\
\hline $\mathrm{C}$ & -2.95002100 & 5.28389100 & -0.03253700 \\
\hline $\mathrm{C}$ & -2.59414200 & 4.14609100 & -0.75316100 \\
\hline $\mathrm{H}$ & 0.35266800 & -0.41925700 & -1.59763800 \\
\hline $\mathrm{H}$ & 0.32438300 & -4.67427000 & 3.54721100 \\
\hline $\mathrm{H}$ & -0.70051700 & -3.95666700 & 5.68794300 \\
\hline $\mathrm{H}$ & -2.13214400 & -1.91281200 & 5.73099500 \\
\hline $\mathrm{H}$ & -2.53921600 & -0.65966700 & 3.66162600 \\
\hline $\mathrm{H}$ & 0.59121800 & -4.55763300 & 1.32001900 \\
\hline $\mathrm{H}$ & -0.49619500 & -3.62433000 & 0.31209300 \\
\hline $\mathrm{H}$ & -1.63681800 & 1.62417500 & 2.05655400 \\
\hline $\mathrm{H}$ & -3.36316700 & 3.23486600 & 2.75964600 \\
\hline $\mathrm{H}$ & -5.77919100 & 2.65465700 & 2.51540400 \\
\hline $\mathrm{H}$ & -6.42017600 & 0.43716700 & 1.59896800 \\
\hline $\mathrm{H}$ & -4.68788300 & -1.17113700 & 0.90090600 \\
\hline $\mathrm{H}$ & -3.21790300 & -3.43487900 & 1.63239100 \\
\hline $\mathrm{H}$ & -4.47937400 & -5.08077400 & 0.29835800 \\
\hline $\mathrm{H}$ & -4.61160900 & -4.85117900 & -2.17266500 \\
\hline $\mathrm{H}$ & -3.46356700 & -2.94586300 & -3.29383500 \\
\hline $\mathrm{H}$ & -2.18554900 & -1.31588100 & -1.95973200 \\
\hline $\mathrm{H}$ & 2.53528200 & -4.27277700 & 2.31856200 \\
\hline $\mathrm{H}$ & 4.13825600 & -3.71616000 & 4.10337300 \\
\hline $\mathrm{H}$ & 4.72320000 & -1.32595900 & 4.54936300 \\
\hline
\end{tabular}

$\begin{array}{lrrr}\mathrm{H} & 3.65529700 & 0.44660400 & 3.20937600 \\ \mathrm{H} & 1.70783100 & 2.92257600 & -0.39643300 \\ \mathrm{H} & 3.44212600 & 4.23450500 & -1.55612900 \\ \mathrm{H} & 5.82921800 & 3.51576000 & -1.44029300 \\ \mathrm{H} & 6.43026000 & 1.46722800 & -0.17165300 \\ \mathrm{H} & 4.68949600 & 0.13923400 & 0.94937300 \\ \mathrm{H} & 2.67337900 & 3.21875200 & 2.16498500 \\ \mathrm{H} & 2.01085700 & 4.55984600 & 4.12440700 \\ \mathrm{H} & 0.29795800 & 3.70910700 & 5.70943000 \\ \mathrm{H} & -0.71867300 & 1.46376100 & 5.33009200 \\ \mathrm{H} & -0.04409200 & 0.12078600 & 3.37299600 \\ \mathrm{H} & 1.13352400 & -4.74706100 & -1.04026300 \\ \mathrm{H} & 0.41531600 & -6.30175400 & -2.81886000 \\ \mathrm{H} & -0.60072200 & -5.42576400 & -4.90742100 \\ \mathrm{H} & -0.90013800 & -2.97253600 & -5.19610000 \\ \mathrm{H} & -0.24615800 & -1.42831300 & -3.38973400 \\ \mathrm{H} & -0.20371000 & 4.70269700 & -1.92567900 \\ \mathrm{H} & 1.32246700 & 5.66870300 & -3.58738900 \\ \mathrm{H} & 2.59503600 & 4.19974000 & -5.13753700 \\ \mathrm{H} & 2.30012700 & 1.72845100 & -4.99680100 \\ \mathrm{H} & 0.78474800 & 0.76171100 & -3.32427100 \\ \mathrm{H} & -3.77001600 & 1.65480300 & -0.59340700 \\ \mathrm{H} & -5.66821300 & 0.60016000 & -1.74401200 \\ \mathrm{H} & -5.38464300 & -0.34866100 & -4.02812100 \\ \mathrm{H} & -3.17120900 & -0.18601900 & -5.15326900 \\ \mathrm{H} & -1.27539800 & 0.87058300 & -4.01067700 \\ \mathrm{H} & 0.03719500 & 3.13061900 & 1.12944400 \\ \mathrm{H} & -0.55657200 & 5.17033200 & 2.38037500 \\ \mathrm{H} & -2.50486900 & 6.54844200 & 1.65324500 \\ \mathrm{H} & -3.79616200 & 5.88298500 & -0.35852500 \\ \mathrm{H} & -3.15867800 & 3.86850400 & -1.64000900 \\ \mathrm{H} & 2.93784700 & -1.47422200 & -1.32857000 \\ \mathrm{C} & 3.91787700 & -2.43624000 & -1.03665100 \\ \mathrm{C} & 3.30592400 & -0.41416600 & -2.16723800 \\ \mathrm{C} & 5.20681000 & -2.33540400 & -1.55287100 \\ \mathrm{C} & 3.66473500 & -3.27731800 & -0.39219300 \\ \mathrm{H} & 4.58490300 & -0.31567100 & -2.70590000 \\ \mathrm{H} & 2.59258000 & 0.38308600 & -2.36241800 \\ \mathrm{H} & 5.54201000 & -1.27723500 & -2.39666800 \\ \mathrm{H} & & -3.08775300 & -1.30287100 \\ \mathrm{H} & 0.53161600 & -3.33936100 \\ \mathrm{H} & & -1.20123000 & -2.80375900\end{array}$

\section{Compound: 2 [SiPhMe $^{1}$ \\ Charge: 0 \\ Multiplicity: 1 \\ Lowest Frequency: $24.88 \mathrm{~cm}^{-1}$ \\ Energy: -5271.374549 Hartree}

$\begin{array}{crrr}\mathrm{Ni} & 0.02276800 & -0.00145500 & -0.38246700 \\ \mathrm{P} & 1.64659800 & 1.48849000 & -0.24549800 \\ \mathrm{P} & -1.67610000 & 0.25814300 & 0.96658700 \\ \mathrm{P} & 0.86992900 & -2.05430500 & -0.12011000 \\ \mathrm{Si} & -1.13040600 & 1.13291600 & -1.93819000 \\ \mathrm{~N} & -1.41360900 & 2.68918100 & -1.08535300 \\ \mathrm{C} & 1.33030800 & 3.14401000 & 0.52509600 \\ \mathrm{C} & 0.37017700 & 4.04275600 & 0.00212800 \\ \mathrm{C} & 0.13214100 & 5.24598900 & 0.67006200\end{array}$




\begin{tabular}{|c|c|c|c|}
\hline $\mathrm{C}$ & 0.80836700 & 5.58788100 & 1.83638800 \\
\hline $\mathrm{C}$ & 1.76167400 & 4.71526200 & 2.34346300 \\
\hline $\mathrm{C}$ & 2.02261900 & 3.51655900 & 1.68600600 \\
\hline $\mathrm{C}$ & -0.42840000 & 3.75738600 & -1.24777000 \\
\hline $\mathrm{C}$ & 3.10942200 & 0.90629900 & 0.71036800 \\
\hline $\mathrm{C}$ & 2.86558600 & 0.21568600 & 1.90330500 \\
\hline $\mathrm{C}$ & 3.90693400 & -0.33067600 & 2.64457600 \\
\hline $\mathrm{C}$ & 5.22034500 & -0.19560300 & 2.19794100 \\
\hline $\mathrm{C}$ & 5.47916900 & 0.50739900 & 1.02364800 \\
\hline $\mathrm{C}$ & 4.43438700 & 1.06016400 & 0.28588300 \\
\hline $\mathrm{C}$ & 2.47950200 & 1.96310400 & -1.81681500 \\
\hline $\mathrm{C}$ & 2.92112600 & 3.25967500 & -2.10205200 \\
\hline $\mathrm{C}$ & 3.59478300 & 3.53329300 & -3.29035500 \\
\hline $\mathrm{C}$ & 3.86130400 & 2.51012900 & -4.19646600 \\
\hline $\mathrm{C}$ & 3.43867700 & 1.21276300 & -3.91460100 \\
\hline $\mathrm{C}$ & 2.74303500 & 0.94474900 & -2.74138600 \\
\hline $\mathrm{C}$ & -2.70646700 & 1.76636000 & 0.79784900 \\
\hline $\mathrm{C}$ & -2.34288200 & 2.83620100 & -0.05456600 \\
\hline $\mathrm{C}$ & -2.99866100 & 4.07384300 & 0.11746100 \\
\hline $\mathrm{C}$ & -4.02598200 & 4.22851500 & 1.03074300 \\
\hline $\mathrm{C}$ & -4.43331200 & 3.15364200 & 1.82359600 \\
\hline $\mathrm{C}$ & -3.75861400 & 1.94989100 & 1.70948200 \\
\hline $\mathrm{C}$ & -2.89567600 & -1.11141000 & 0.96092300 \\
\hline $\mathrm{C}$ & -2.50844400 & -2.35358000 & 1.48626000 \\
\hline $\mathrm{C}$ & -3.36346700 & -3.44666600 & 1.45022600 \\
\hline $\mathrm{C}$ & -4.61615500 & -3.32997200 & 0.85083000 \\
\hline $\mathrm{C}$ & -5.00394600 & -2.11112800 & 0.30251400 \\
\hline $\mathrm{C}$ & -4.15660900 & -1.00642000 & 0.36493500 \\
\hline $\mathrm{C}$ & -1.31301100 & 0.40513000 & 2.78036600 \\
\hline $\mathrm{C}$ & -1.97315700 & -0.29888800 & 3.79433800 \\
\hline $\mathrm{C}$ & -1.58691500 & -0.15279400 & 5.12580800 \\
\hline $\mathrm{C}$ & -0.54689500 & 0.70557900 & 5.47080400 \\
\hline $\mathrm{C}$ & 0.09509100 & 1.43670000 & 4.47329300 \\
\hline $\mathrm{C}$ & -0.28994100 & 1.28676100 & 3.14663500 \\
\hline $\mathrm{C}$ & -0.24542100 & -3.41489400 & -0.68321500 \\
\hline $\mathrm{C}$ & 0.10110600 & -4.76614900 & -0.56168200 \\
\hline $\mathrm{C}$ & -0.74816100 & -5.76068400 & -1.03475800 \\
\hline $\mathrm{C}$ & -1.95533900 & -5.42145300 & -1.64471100 \\
\hline $\mathrm{C}$ & -2.30913300 & -4.08270700 & -1.77192400 \\
\hline $\mathrm{C}$ & -1.46197000 & -3.09089100 & -1.28675400 \\
\hline $\mathrm{C}$ & 2.27978200 & -2.29924100 & -1.26856900 \\
\hline $\mathrm{C}$ & 3.58536900 & -1.96053400 & -0.88948500 \\
\hline $\mathrm{C}$ & 4.62062100 & -1.98277300 & -1.81947300 \\
\hline $\mathrm{C}$ & 4.36948600 & -2.33694900 & -3.14271200 \\
\hline $\mathrm{C}$ & 3.07345900 & -2.67212000 & -3.53084700 \\
\hline $\mathrm{C}$ & 2.03656300 & -2.65215400 & -2.60326100 \\
\hline $\mathrm{C}$ & 1.52658600 & -2.74949500 & 1.45674900 \\
\hline $\mathrm{C}$ & 0.97669800 & -2.29796100 & 2.66203000 \\
\hline $\mathrm{C}$ & 1.40233600 & -2.80468100 & 3.88597700 \\
\hline $\mathrm{C}$ & 2.40545700 & -3.76982900 & 3.92673600 \\
\hline $\mathrm{C}$ & 2.97334500 & -4.22126100 & 2.73766600 \\
\hline $\mathrm{C}$ & 2.53605900 & -3.71977000 & 1.51483800 \\
\hline $\mathrm{H}$ & -0.22590200 & -0.35039700 & -1.88379800 \\
\hline $\mathrm{H}$ & -0.60907100 & 5.92599000 & 0.25401600 \\
\hline $\mathrm{H}$ & 0.59244200 & 6.52670800 & 2.33849100 \\
\hline $\mathrm{H}$ & 2.31346800 & 4.96388000 & 3.24617000 \\
\hline $\mathrm{H}$ & 2.77599800 & 2.85124200 & 2.09771200 \\
\hline $\mathrm{H}$ & -0.90764900 & 4.69149100 & -1.57872100 \\
\hline
\end{tabular}

\begin{tabular}{|c|c|c|c|}
\hline $\mathrm{H}$ & 0.23808100 & 3.46533600 & -2.06469600 \\
\hline $\mathrm{H}$ & 1.83821700 & 0.08862900 & 2.23755800 \\
\hline $\mathrm{H}$ & 3.68335400 & -0.88411000 & 3.55388600 \\
\hline $\mathrm{H}$ & 6.03746400 & -0.63860000 & 2.76084400 \\
\hline $\mathrm{H}$ & 6.50140100 & 0.61975700 & 0.67068900 \\
\hline $\mathrm{H}$ & 4.65382300 & 1.59113800 & -0.63675000 \\
\hline $\mathrm{H}$ & 2.73800600 & 4.06207200 & -1.39076300 \\
\hline $\mathrm{H}$ & 3.91963000 & 4.54852700 & -3.50282100 \\
\hline $\mathrm{H}$ & 4.39292200 & 2.72415600 & -5.11972000 \\
\hline $\mathrm{H}$ & 3.63678900 & 0.40373800 & -4.61329000 \\
\hline $\mathrm{H}$ & 2.38138800 & -0.06225200 & -2.54556500 \\
\hline $\mathrm{H}$ & -2.71964800 & 4.90620600 & -0.52255300 \\
\hline $\mathrm{H}$ & -4.52371600 & 5.19128900 & 1.11639800 \\
\hline $\mathrm{H}$ & -5.24675200 & 3.26421100 & 2.53414100 \\
\hline $\mathrm{H}$ & -4.03317300 & 1.12077200 & 2.36036500 \\
\hline $\mathrm{H}$ & -1.51477200 & -2.46767900 & 1.91710800 \\
\hline $\mathrm{H}$ & -3.03611400 & -4.39892300 & 1.85994400 \\
\hline $\mathrm{H}$ & -5.28099700 & -4.18829000 & 0.80394800 \\
\hline $\mathrm{H}$ & -5.97651200 & -2.00988300 & -0.17240600 \\
\hline $\mathrm{H}$ & -4.47810000 & -0.05707200 & -0.05239200 \\
\hline $\mathrm{H}$ & -2.78829700 & -0.97343800 & 3.54810500 \\
\hline $\mathrm{H}$ & -2.10706800 & -0.71502400 & 5.89730300 \\
\hline $\mathrm{H}$ & -0.24363200 & 0.80851700 & 6.50925200 \\
\hline $\mathrm{H}$ & 0.90210700 & 2.12295700 & 4.72062100 \\
\hline $\mathrm{H}$ & 0.21666500 & 1.85865000 & 2.37407300 \\
\hline $\mathrm{H}$ & 1.03979600 & -5.04731600 & -0.09066500 \\
\hline $\mathrm{H}$ & -0.46483700 & -6.80484000 & -0.93006200 \\
\hline $\mathrm{H}$ & -2.61746300 & -6.20083700 & -2.01282500 \\
\hline $\mathrm{H}$ & -3.25728700 & -3.79668400 & -2.22185400 \\
\hline $\mathrm{H}$ & -1.76669500 & -2.05033700 & -1.34499400 \\
\hline $\mathrm{H}$ & 3.79387900 & -1.67099200 & 0.13851600 \\
\hline $\mathrm{H}$ & 5.62573200 & -1.71098700 & -1.50598600 \\
\hline $\mathrm{H}$ & 5.17809400 & -2.34855100 & -3.86879600 \\
\hline $\mathrm{H}$ & 2.86682200 & -2.94934000 & -4.56136100 \\
\hline $\mathrm{H}$ & 1.02413800 & -2.90185000 & -2.91570400 \\
\hline $\mathrm{H}$ & 0.22725000 & -1.51041500 & 2.64217800 \\
\hline $\mathrm{H}$ & 0.95611400 & -2.43109100 & 4.80416200 \\
\hline $\mathrm{H}$ & 2.74957200 & -4.16270800 & 4.87958800 \\
\hline $\mathrm{H}$ & 3.76221800 & -4.96860200 & 2.76026000 \\
\hline $\mathrm{H}$ & 2.99989300 & -4.07224300 & 0.59675800 \\
\hline $\mathrm{C}$ & -2.85098900 & 0.51107000 & -2.42523500 \\
\hline $\mathrm{C}$ & -4.03506400 & 1.25226700 & -2.28507100 \\
\hline $\mathrm{C}$ & -2.93940900 & -0.70176200 & -3.12797700 \\
\hline $\mathrm{C}$ & -5.25234600 & 0.77769000 & -2.76977200 \\
\hline $\mathrm{H}$ & -4.01371300 & 2.21815500 & -1.78479000 \\
\hline $\mathrm{C}$ & -4.15017100 & -1.18327800 & -3.61803500 \\
\hline $\mathrm{H}$ & -2.03435300 & -1.28370300 & -3.30694300 \\
\hline $\mathrm{C}$ & -5.31725200 & -0.44859500 & -3.42655700 \\
\hline $\mathrm{H}$ & -6.15333700 & 1.37195500 & -2.63636300 \\
\hline $\mathrm{H}$ & -4.17986800 & -2.12703900 & -4.15852200 \\
\hline $\mathrm{H}$ & -6.26726100 & -0.82085200 & -3.80118600 \\
\hline $\mathrm{C}$ & -0.44045800 & 1.66638700 & -3.61439300 \\
\hline $\mathrm{H}$ & 0.55927200 & 2.10328300 & -3.61522800 \\
\hline $\mathrm{H}$ & -0.39536300 & 0.77739200 & -4.25414900 \\
\hline $\mathrm{H}$ & -1.12951600 & 2.37577000 & -4.08555500 \\
\hline
\end{tabular}

Compound: $2[\mathrm{SiPhMe}]^{2}$

Charge: 0 
Multiplicity: 1

Lowest Frequency: $27.41 \mathrm{~cm}^{-1}$

Energy: -5271.373599 Hartree

\begin{tabular}{|c|c|c|c|}
\hline $\mathrm{Ni}$ & -0.03299100 & -0.00718900 & -0.29609200 \\
\hline$P$ & 1.52862000 & -0.04467900 & 1.26151600 \\
\hline $\mathrm{P}$ & -1.44228000 & 1.66106500 & -0.27739800 \\
\hline$P$ & -1.12099200 & -1.92697200 & -0.35525900 \\
\hline $\mathrm{Si}$ & 1.14640900 & 1.13640500 & -1.84879400 \\
\hline $\mathrm{N}$ & 1.54542200 & 2.61954100 & -0.93263800 \\
\hline $\mathrm{C}$ & 1.91201900 & 1.52823900 & 2.15220200 \\
\hline $\mathrm{C}$ & 2.37261100 & 2.66132300 & 1.44246900 \\
\hline $\mathrm{C}$ & 2.55018100 & 3.86388300 & 2.12902100 \\
\hline $\mathrm{C}$ & 2.28674600 & 3.97832800 & 3.49049700 \\
\hline $\mathrm{C}$ & 1.86319400 & 2.85850800 & 4.19425100 \\
\hline $\mathrm{C}$ & 1.68913000 & 1.64716300 & 3.53039100 \\
\hline $\mathrm{C}$ & 2.70342600 & 2.62679500 & -0.03162700 \\
\hline $\mathrm{C}$ & 1.17690200 & -1.19776100 & 2.65059900 \\
\hline $\mathrm{C}$ & -0.12141900 & -1.18806200 & 3.17645600 \\
\hline $\mathrm{C}$ & -0.50241100 & -2.08831700 & 4.16400600 \\
\hline $\mathrm{C}$ & 0.41482600 & -3.02376300 & 4.64132600 \\
\hline $\mathrm{C}$ & 1.71389100 & -3.03234100 & 4.13984000 \\
\hline $\mathrm{C}$ & 2.09706500 & -2.12425700 & 3.15458400 \\
\hline $\mathrm{C}$ & 3.21496900 & -0.60004100 & 0.77750800 \\
\hline $\mathrm{C}$ & 4.38730500 & -0.06048000 & 1.32411000 \\
\hline $\mathrm{C}$ & 5.63492400 & -0.53141500 & 0.92771800 \\
\hline $\mathrm{C}$ & 5.73028900 & -1.56525900 & -0.00140500 \\
\hline $\mathrm{C}$ & 4.57165300 & -2.12717100 & -0.52719200 \\
\hline $\mathrm{C}$ & 3.32446900 & -1.64284100 & -0.14616200 \\
\hline $\mathrm{C}$ & -0.78256300 & 3.35956600 & -0.52617600 \\
\hline $\mathrm{C}$ & 0.59384800 & 3.62724000 & -0.71899500 \\
\hline $\mathrm{C}$ & 1.02338600 & 4.96900800 & -0.69250200 \\
\hline $\mathrm{C}$ & 0.13488200 & 6.01432800 & -0.51705100 \\
\hline $\mathrm{C}$ & -1.22790400 & 5.75560700 & -0.35631000 \\
\hline $\mathrm{C}$ & -1.66367300 & 4.44151600 & -0.35522100 \\
\hline $\mathrm{C}$ & -2.84650700 & 1.57602000 & -1.46552000 \\
\hline $\mathrm{C}$ & -3.74432900 & 0.50459600 & -1.35857200 \\
\hline $\mathrm{C}$ & -4.80403500 & 0.36336500 & -2.24605800 \\
\hline $\mathrm{C}$ & -4.97651400 & 1.28277300 & -3.27876100 \\
\hline $\mathrm{C}$ & -4.09154100 & 2.34821800 & -3.40234400 \\
\hline $\mathrm{C}$ & -3.04435000 & 2.50068600 & -2.49667100 \\
\hline $\mathrm{C}$ & -2.36351300 & 1.94965500 & 1.30505300 \\
\hline $\mathrm{C}$ & -3.75525600 & 2.01792600 & 1.43449400 \\
\hline $\mathrm{C}$ & -4.34246000 & 2.15784700 & 2.69187600 \\
\hline $\mathrm{C}$ & -3.55440300 & 2.24340600 & 3.83574300 \\
\hline $\mathrm{C}$ & -2.16637700 & 2.21022300 & 3.71405000 \\
\hline $\mathrm{C}$ & -1.58327400 & 2.06787800 & 2.46107900 \\
\hline $\mathrm{C}$ & 0.18789600 & 1.69720700 & -3.37157000 \\
\hline $\mathrm{C}$ & 2.79311800 & 0.56263100 & -2.58971900 \\
\hline $\mathrm{C}$ & 3.89558800 & 1.40524800 & -2.78796800 \\
\hline $\mathrm{C}$ & 5.02741600 & 0.97623300 & -3.47815800 \\
\hline $\mathrm{C}$ & 5.07351000 & -0.30799700 & -4.01283500 \\
\hline $\mathrm{C}$ & 3.98113400 & -1.15758100 & -3.85146000 \\
\hline $\mathrm{C}$ & 2.86493400 & -0.72470000 & -3.14408700 \\
\hline $\mathrm{C}$ & -2.12496500 & -2.16945000 & -1.89010900 \\
\hline $\mathrm{C}$ & -3.27429400 & -2.96735400 & -1.93073100 \\
\hline $\mathrm{C}$ & -4.03715900 & -3.05619500 & -3.09273800 \\
\hline $\mathrm{C}$ & -3.66587100 & -2.35222700 & -4.23516600 \\
\hline
\end{tabular}

$-2.51828200 \quad-1.56435600 \quad-4.21179400$

$-1.76109200-1.47112700 \quad-3.04982300$

$\begin{array}{llll}0.09468300 & -3.29293600 & -0.47931800\end{array}$

$\begin{array}{llll}0.63391100 & -3.87386000 & 0.67584000\end{array}$

$\begin{array}{llll}1.70389600 & -4.75958200 & 0.58822900\end{array}$

$\begin{array}{llll}2.25741900 & -5.07476700 & -0.65036900\end{array}$

$\begin{array}{llll}1.72704700 & -4.50334800 & -1.80555900\end{array}$

$\begin{array}{llll}0.65412600 & -3.62110200 & -1.72119600\end{array}$

$-2.27376000 \quad-2.51749300 \quad 0.94796400$

$\begin{array}{lll}-2.98498200 & -1.56087300 & 1.68084100\end{array}$

$\begin{array}{lll}-3.89589000 & -1.93886100 & 2.66232600\end{array}$

$\begin{array}{lll}-4.09701400 & -3.28862000 & 2.93973700\end{array}$

$\begin{array}{lll}-3.38905000 & -4.25340400 & 2.22568800\end{array}$

$\begin{array}{lll}-2.49019600 & -3.87179800 & 1.23372900\end{array}$

$\begin{array}{lll}0.64286000 & -0.47250100 & -1.62095200\end{array}$

$\begin{array}{llll}2.90821100 & 4.72754400 & 1.57174900\end{array}$

$\begin{array}{llll}2.42243200 & 4.93106300 & 3.99438500\end{array}$

$\begin{array}{lll}1.67077800 & 2.91870000 & 5.26241500\end{array}$

$\begin{array}{lll}1.35552200 & 0.78078400 & 4.09493800\end{array}$

$3.35840400 \quad 3.48398700 \quad-0.25411600$

$\begin{array}{llll}3.29521200 & 1.73381400 & -0.25754400\end{array}$

$\begin{array}{lll}-0.83990100 & -0.46383200 & 2.79542600\end{array}$

$\begin{array}{lll}-1.52166500 & -2.06980700 & 4.54248000\end{array}$

$\begin{array}{llll}0.11718700 & -3.74239900 & 5.40021600\end{array}$

$\begin{array}{lll}2.43547600 & -3.75573300 & 4.51133500\end{array}$

$\begin{array}{llll}3.10930900 & -2.15562100 & 2.75940400\end{array}$

$\begin{array}{lll}4.32354100 & 0.74216000 & 2.05563300\end{array}$

$\begin{array}{lll}6.53526100 & -0.09030300 & 1.34751200\end{array}$

$\begin{array}{llll}6.70507200 & -1.92850100 & -0.31572500\end{array}$

$\begin{array}{llll}4.63164300 & -2.92855800 & -1.25975100\end{array}$

$\begin{array}{llll}2.42425500 & -2.06389500 & -0.58958700\end{array}$

$\begin{array}{llll}2.08034200 & 5.17416800 & -0.84467200\end{array}$

$\begin{array}{llll}0.50179900 & 7.03768500 & -0.51811000\end{array}$

$\begin{array}{lll}-1.93546600 & 6.56819300 & -0.22140700\end{array}$

$\begin{array}{llll}-2.72095400 & 4.23136400 & -0.19868000\end{array}$

$\begin{array}{llll}-3.60842200 & -0.22978700 & -0.56610600\end{array}$

$\begin{array}{llll}-5.47958800 & -0.48175400 & -2.14311900\end{array}$

$\begin{array}{lll}-5.79380800 & 1.16367400 & -3.98498100\end{array}$

$\begin{array}{llll}-4.21667600 & 3.07281600 & -4.20254400\end{array}$

$\begin{array}{llll}-2.36614700 & 3.34292500 & -2.60219200\end{array}$

$\begin{array}{lll}-4.39058000 & 1.95572300 & 0.55576400\end{array}$

$\begin{array}{lll}-5.42573900 & 2.20124900 & 2.77276800\end{array}$

$\begin{array}{lll}-4.01759300 & 2.34413700 & 4.81346100\end{array}$

$\begin{array}{lll}-1.53229300 & 2.28918000 & 4.59429100\end{array}$

$\begin{array}{lll}-0.50139000 & 2.04322600 & 2.36828000\end{array}$

$\begin{array}{llll}-0.89603200 & 1.70221300 & -3.25359500\end{array}$

$\begin{array}{llll}0.41789500 & 1.00517700 & -4.19023000\end{array}$

$\begin{array}{llll}0.50895700 & 2.69435400 & -3.69154600\end{array}$

$\begin{array}{llll}3.86441800 & 2.42487700 & -2.40664700\end{array}$

$\begin{array}{llll}5.87160300 & 1.64958800 & -3.60617600\end{array}$

$\begin{array}{lll}5.95379300 & -0.64390600 & -4.55504600\end{array}$

$\begin{array}{llll}4.00487100 & -2.16342200 & -4.26629400\end{array}$

$\begin{array}{llll}2.02838200 & -1.41318200 & -3.00309300\end{array}$

$\begin{array}{llll}-3.58992500 & -3.51086500 & -1.04397200\end{array}$

$\begin{array}{llll}-4.93156600 & -3.67399600 & -3.09996900\end{array}$

$\begin{array}{llll}-4.27183900 & -2.41169000 & -5.13528000\end{array}$

$\begin{array}{lll}-2.21989600 & -0.99846700 & -5.09099700\end{array}$

$\begin{array}{llll}-0.88989900 & -0.82134000 & -3.03015200\end{array}$ 


$\begin{array}{lrrr}\mathrm{H} & 0.21582800 & -3.62950100 & 1.65024000 \\ \mathrm{H} & 2.11186100 & -5.19392200 & 1.49773100 \\ \mathrm{H} & 3.10051100 & -5.75723000 & -0.71498100 \\ \mathrm{H} & 2.15132600 & -4.74190400 & -2.77821100 \\ \mathrm{H} & 0.25218500 & -3.17068000 & -2.62712500 \\ \mathrm{H} & -2.79998800 & -0.50465200 & 1.49569900 \\ \mathrm{H} & -4.43404600 & -1.17416700 & 3.21674100 \\ \mathrm{H} & -4.79851200 & -3.58945700 & 3.71338700 \\ \mathrm{H} & -3.54017100 & -5.30845100 & 2.43848400 \\ \mathrm{H} & -1.94482900 & -4.63192800 & 0.67896100\end{array}$

Compound: 3 [Si]

Charge: 0

Multiplicity: 1

Lowest Frequency: $13.18 \mathrm{~cm}^{-1}$

Energy: -5620.333045 Hartree

\begin{tabular}{|c|c|c|c|}
\hline $\mathrm{Ni}$ & 2.02869500 & -0.31211100 & -0.15948400 \\
\hline$P$ & 1.81332400 & 1.79041500 & -0.17927300 \\
\hline$P$ & -5.48867000 & -0.09232700 & -0.73786000 \\
\hline $\mathrm{P}$ & 4.03314900 & -1.17239300 & -0.08025600 \\
\hline $\mathrm{Si}$ & -0.10068900 & -0.60702800 & -0.14394700 \\
\hline $\mathrm{N}$ & -1.10969300 & 0.89717400 & -0.43689400 \\
\hline $\mathrm{C}$ & 0.58367200 & 2.40043000 & -1.38051300 \\
\hline $\mathrm{C}$ & -0.74350500 & 1.88088900 & -1.35323500 \\
\hline $\mathrm{C}$ & -1.68107000 & 2.44487900 & -2.24392200 \\
\hline $\mathrm{C}$ & -1.33164000 & 3.45369900 & -3.12909400 \\
\hline $\mathrm{C}$ & -0.03361300 & 3.95190200 & -3.16074300 \\
\hline $\mathrm{C}$ & 0.90230800 & 3.42400100 & -2.27930200 \\
\hline $\mathrm{C}$ & 3.32474000 & 2.72710600 & -0.61348800 \\
\hline $\mathrm{C}$ & 4.01066400 & 2.39691200 & -1.80632400 \\
\hline $\mathrm{C}$ & 5.18028600 & 3.09283000 & -2.11556700 \\
\hline $\mathrm{C}$ & 5.68036900 & 4.08567300 & -1.27884300 \\
\hline $\mathrm{C}$ & 5.01623400 & 4.39099600 & -0.09626700 \\
\hline $\mathrm{C}$ & 3.84652300 & 3.71171500 & 0.23201800 \\
\hline $\mathrm{C}$ & 1.23522100 & 2.56082600 & 1.38986200 \\
\hline $\mathrm{C}$ & 1.54806100 & 2.01982900 & 2.65492400 \\
\hline $\mathrm{C}$ & 1.06297200 & 2.66955400 & 3.79517700 \\
\hline $\mathrm{C}$ & 0.30067700 & 3.82872600 & 3.71194900 \\
\hline $\mathrm{C}$ & 0.02010800 & 4.37717400 & 2.46512400 \\
\hline $\mathrm{C}$ & 0.48762600 & 3.74386400 & 1.31888000 \\
\hline $\mathrm{C}$ & 3.49429300 & 1.35126100 & -2.74699000 \\
\hline $\mathrm{C}$ & 2.35380900 & 0.77086000 & 2.82970800 \\
\hline $\mathrm{C}$ & -0.87485800 & -1.78345700 & -1.40500800 \\
\hline $\mathrm{C}$ & -0.48047900 & -1.66728300 & -2.74808300 \\
\hline $\mathrm{C}$ & -1.04330200 & -2.46273500 & -3.74193100 \\
\hline $\mathrm{C}$ & -2.01948000 & -3.40060800 & -3.40874500 \\
\hline $\mathrm{C}$ & -2.43062300 & -3.52765800 & -2.08443800 \\
\hline $\mathrm{C}$ & -1.86784700 & -2.72271000 & -1.09537100 \\
\hline $\mathrm{C}$ & -0.59541900 & -1.07149200 & 1.61608600 \\
\hline $\mathrm{C}$ & -0.34221000 & -2.36269600 & 2.10869100 \\
\hline $\mathrm{C}$ & -0.53521000 & -2.67946800 & 3.45095100 \\
\hline $\mathrm{C}$ & -0.98077600 & -1.70079300 & 4.33927900 \\
\hline $\mathrm{C}$ & -1.25150400 & -0.41638000 & 3.87036700 \\
\hline $\mathrm{C}$ & -1.06310600 & -0.10901900 & 2.52460400 \\
\hline $\mathrm{C}$ & -4.84097500 & 1.34002200 & 0.21591600 \\
\hline $\mathrm{C}$ & -3.44505900 & 1.56388000 & 0.24093800 \\
\hline $\mathrm{C}$ & -2.94400800 & 2.68069600 & 0.90885600 \\
\hline
\end{tabular}

$\begin{array}{llll}-3.79468700 & 3.58301400 & 1.53884300\end{array}$ $\begin{array}{llll}-5.16915300 & 3.37130100 & 1.51299900\end{array}$ $\begin{array}{lll}-5.68342900 & 2.25488900 & 0.86035400\end{array}$ $\begin{array}{llll}-2.52611100 & 0.54868600 & -0.38518500\end{array}$ $\begin{array}{llll}-5.06930800 & -1.52816700 & 0.33062300\end{array}$ $\begin{array}{lll}-5.28570400 & -2.82905500 & -0.17852900\end{array}$ $\begin{array}{lll}-4.86938800 & -3.92578900 & 0.58070000\end{array}$ $\begin{array}{lll}-4.22973100 & -3.76339600 & 1.80653100\end{array}$ $\begin{array}{lll}-4.02032400 & -2.48320600 & 2.30846600\end{array}$ $\begin{array}{lll}-4.44959200 & -1.37958100 & 1.57790600\end{array}$ $\begin{array}{llll}-5.94576000 & -3.04280500 & -1.50610900\end{array}$ $\begin{array}{llll}5.56398400 & -0.21458000 & -0.36956800\end{array}$ $\begin{array}{lll}6.34476300 & -0.34951700 & -1.52189500\end{array}$ $\begin{array}{llll}7.48272300 & 0.43528800 & -1.70037400\end{array}$ $\begin{array}{llll}7.85504400 & 1.36152900 & -0.73219900\end{array}$ $\begin{array}{lll}7.07363100 & 1.51659100 & 0.41224300\end{array}$ $\begin{array}{llll}5.93348500 & 0.74392900 & 0.58502800\end{array}$

$\begin{array}{llll}4.18202800 & -2.53362700 & -1.29670500\end{array}$ $3.20556100 \quad-2.64812600 \quad-2.29064400$ $3.28186800 \quad-3.65690100 \quad-3.24630000$ $\begin{array}{lll}4.33586900 & -4.56562900 & -3.21179500\end{array}$ $\begin{array}{llll}5.31200500 & -4.46377100 & -2.22108300\end{array}$ $\begin{array}{llll}5.23686900 & -3.45273900 & -1.26888600\end{array}$ $\begin{array}{llll}4.37493900 & -1.98070800 & 1.53063400\end{array}$ $\begin{array}{lll}3.28169900 & -2.44985400 & 2.26990600\end{array}$ $\begin{array}{llll}3.47029300 & -3.07470500 & 3.49737500\end{array}$ $\begin{array}{llll}4.75719600 & -3.24452400 & 4.00240800\end{array}$ $\begin{array}{lll}5.85229700 & -2.78645300 & 3.27375000\end{array}$ $\begin{array}{lll}5.66484800 & -2.15685200 & 2.04620500\end{array}$ $\begin{array}{lll}1.43804000 & -1.70424000 & -0.15586000\end{array}$ $\begin{array}{lll}-2.70637500 & 2.09236200 & -2.23819700\end{array}$ $\begin{array}{llll}-2.08973800 & 3.85415000 & -3.79727500\end{array}$ $\begin{array}{llll}0.24503500 & 4.74884600 & -3.84297600\end{array}$ $\begin{array}{llll}1.90938600 & 3.83277000 & -2.27227000\end{array}$ $\begin{array}{llll}5.71161600 & 2.83723000 & -3.03033200\end{array}$ $\begin{array}{llll}6.59607400 & 4.60705800 & -1.54544700\end{array}$ $\begin{array}{llll}5.40173900 & 5.15789200 & 0.57011600\end{array}$ $\begin{array}{llll}3.32356000 & 3.95790400 & 1.15298100\end{array}$ $\begin{array}{lll}1.29013800 & 2.24104600 & 4.76932100\end{array}$ $\begin{array}{lll}-0.06442200 & 4.30462000 & 4.61791200\end{array}$ $\begin{array}{lll}-0.56150300 & 5.29093700 & 2.37923300\end{array}$ $\begin{array}{llll}0.25754100 & 4.16636200 & 0.34326700\end{array}$ $\begin{array}{llll}3.10787000 & 0.47757900 & -2.19818000\end{array}$ $\begin{array}{llll}4.27520900 & 1.01145100 & -3.43276100\end{array}$ $\begin{array}{llll}2.65294900 & 1.72043900 & -3.34568100\end{array}$ $\begin{array}{lll}1.78711700 & -0.11360300 & 2.50809200\end{array}$ $\begin{array}{lll}2.61798000 & 0.61244500 & 3.87931600\end{array}$ $\begin{array}{llll}3.28358100 & 0.78893300 & 2.24887900\end{array}$ $\begin{array}{llll}0.27794600 & -0.92753500 & -3.01851000\end{array}$ $\begin{array}{lll}-0.72600000 & -2.34989900 & -4.77603100\end{array}$ $\begin{array}{llll}-2.46093100 & -4.02643100 & -4.18014600\end{array}$ $-3.19813200 \quad-4.25099500-1.81628900$ $-2.21565800 \quad-2.82388400 \quad-0.06537200$ $\begin{array}{llll}0.02271100 & -3.13147500 & 1.42575500\end{array}$ $\begin{array}{lll}-0.33635100 & -3.68853500 & 3.80558500\end{array}$ $\begin{array}{lll}-1.12089800 & -1.94027800 & 5.39035000\end{array}$ $\begin{array}{lll}-1.60223900 & 0.35283900 & 4.55484300\end{array}$ $\begin{array}{lll}-1.26241000 & 0.90255800 & 2.17065600\end{array}$ 


$\begin{array}{lrrr}\mathrm{H} & -1.86811600 & 2.83155600 & 0.93014700 \\ \mathrm{H} & -3.38057400 & 4.44757800 & 2.05144400 \\ \mathrm{H} & -5.84339600 & 4.06572300 & 2.00688200 \\ \mathrm{H} & -6.75760700 & 2.08478800 & 0.85545900 \\ \mathrm{H} & -2.60388400 & -0.36957600 & 0.21100700 \\ \mathrm{H} & -2.91399800 & 0.25164100 & -1.37631600 \\ \mathrm{H} & -5.03834700 & -4.92630800 & 0.18554300 \\ \mathrm{H} & -3.89164100 & -4.63307200 & 2.36388200 \\ \mathrm{H} & -3.51537500 & -2.33554200 & 3.25908000 \\ \mathrm{H} & -4.27979900 & -0.38127700 & 1.97670100 \\ \mathrm{H} & -5.96791500 & -4.10285700 & -1.77289800 \\ \mathrm{H} & -5.41897200 & -2.50059500 & -2.30060400 \\ \mathrm{H} & -6.97902300 & -2.67496600 & -1.51025100 \\ \mathrm{H} & 6.06761900 & -1.07607300 & -2.28144100 \\ \mathrm{H} & 8.08183600 & 0.31493800 & -2.59914900 \\ \mathrm{H} & 8.74449200 & 1.97016100 & -0.87092300 \\ \mathrm{H} & 7.34534600 & 2.25203100 & 1.16447900 \\ \mathrm{H} & 5.32507200 & 0.87046400 & 1.47986900 \\ \mathrm{H} & 2.36696900 & -1.95280700 & -2.28789700 \\ \mathrm{H} & 2.50833700 & -3.73649400 & -4.00531200 \\ \mathrm{H} & 4.39478300 & -5.35938600 & -3.95137100 \\ \mathrm{H} & 6.13090900 & -5.17715100 & -2.18850100 \\ \mathrm{H} & 5.99867400 & -3.37714000 & -0.49474900 \\ \mathrm{H} & 2.27601300 & -2.30157600 & 1.88019400 \\ \mathrm{H} & 2.60647100 & -3.41765300 & 4.06084600 \\ \mathrm{H} & 4.90715400 & -3.72781400 & 4.96386500 \\ \mathrm{H} & 6.85840900 & -2.91546400 & 3.66338700 \\ \mathrm{H} & 6.52493900 & -1.78867300 & 1.49154600 \\ \mathrm{C} & -7.30641500 & 0.06526000 & -0.53433700 \\ \mathrm{C} & -7.99497800 & 1.00532600 & -1.33541400 \\ \mathrm{C} & -9.38569000 & 1.08426400 & -1.23202300 \\ \mathrm{C} & -10.10082400 & 0.25489200 & -0.37358700 \\ \mathrm{C} & -9.42279100 & -0.67355400 & 0.40899500 \\ \mathrm{C} & -8.03639000 & -0.76121900 & 0.32873100 \\ \mathrm{H} & -7.25973800 & 1.92466700 & -2.26240300 \\ \mathrm{H} & -9.91339000 & 1.81101200 & -1.84677700 \\ \mathrm{H} & -11.18314900 & 0.33378200 & -0.31936000 \\ \mathrm{H} & -9.96776600 & -1.32540500 & 1.08621400 \\ \mathrm{H} & -7.50686000 & -1.48229900 & 0.94722700 \\ \mathrm{H} & -6.94902000 & 2.47397200 & -2.90834500 \\ \mathrm{H} & -6.66276100 & 2.66094800 & -1.70982600\end{array}$

Compound: $4[\mathrm{Si}]$

Charge: 0

Multiplicity: 1

Lowest Frequency: $18.19 \mathrm{~cm}^{-1}$

Energy: -5620.333828 Hartree

$\begin{array}{lrrr}\mathrm{Ni} & 2.03942700 & -0.33020000 & -0.19867000 \\ \mathrm{P} & 1.80624200 & 1.77009600 & -0.19354500 \\ \mathrm{P} & -5.50531900 & -0.07459700 & -0.73697600 \\ \mathrm{P} & 4.05591400 & -1.15970700 & -0.08432000 \\ \mathrm{Si} & -0.09322000 & -0.64655500 & -0.19910800 \\ \mathrm{~N} & -1.10612300 & 0.85837800 & -0.46493000 \\ \mathrm{C} & 0.57875700 & 2.37487000 & -1.39994900 \\ \mathrm{C} & -0.74689100 & 1.85093800 & -1.37548700 \\ \mathrm{C} & -1.68666600 & 2.41813500 & -2.26162500\end{array}$




\begin{tabular}{|c|c|c|c|}
\hline $\mathrm{C}$ & 4.72546400 & -3.24986400 & 3.99967700 \\
\hline $\mathrm{C}$ & 5.82554400 & -2.75564400 & 3.30306200 \\
\hline $\mathrm{C}$ & 5.65193800 & -2.12175400 & 2.07591300 \\
\hline $\mathrm{H}$ & 1.45818500 & -1.72649400 & -0.22988100 \\
\hline $\mathrm{H}$ & -2.71226900 & 2.06602500 & -2.25701300 \\
\hline $\mathrm{H}$ & -2.09826100 & 3.83496700 & -3.80730800 \\
\hline $\mathrm{H}$ & 0.23550000 & 4.72950600 & -3.85494000 \\
\hline $\mathrm{H}$ & 1.90315300 & 3.81032700 & -2.28937800 \\
\hline $\mathrm{H}$ & 5.73294900 & 2.89036500 & -2.98218800 \\
\hline $\mathrm{H}$ & 6.53837900 & 4.70237500 & -1.50281500 \\
\hline $\mathrm{H}$ & 5.28358100 & 5.24882000 & 0.57878700 \\
\hline $\mathrm{H}$ & 3.23493400 & 3.99432200 & 1.14017900 \\
\hline $\mathrm{H}$ & 1.19559200 & 2.17050700 & 4.75071600 \\
\hline $\mathrm{H}$ & -0.10580200 & 4.26670600 & 4.59745500 \\
\hline $\mathrm{H}$ & -0.53674000 & 5.28967700 & 2.36060400 \\
\hline $\mathrm{H}$ & 0.29087000 & 4.16416800 & 0.32764200 \\
\hline $\mathrm{H}$ & 3.15897200 & 0.48336600 & -2.18565600 \\
\hline $\mathrm{H}$ & 4.33316200 & 1.03560000 & -3.40737500 \\
\hline $\mathrm{H}$ & 2.69739400 & 1.71470000 & -3.34239900 \\
\hline $\mathrm{H}$ & 1.71573400 & -0.16465800 & 2.42746400 \\
\hline $\mathrm{H}$ & 2.46425800 & 0.49999500 & 3.87523700 \\
\hline $\mathrm{H}$ & 3.23277500 & 0.72432500 & 2.29752300 \\
\hline $\mathrm{H}$ & 0.37357200 & -1.08211200 & -3.06301900 \\
\hline $\mathrm{H}$ & -0.64422700 & -2.51417400 & -4.80342500 \\
\hline $\mathrm{H}$ & -2.47623500 & -4.08451900 & -4.20991300 \\
\hline $\mathrm{H}$ & -3.29235600 & -4.19633100 & -1.86311300 \\
\hline $\mathrm{H}$ & -2.28977300 & -2.76676800 & -0.12916400 \\
\hline $\mathrm{H}$ & 0.02473800 & -3.19770500 & 1.31470700 \\
\hline $\mathrm{H}$ & -0.34306300 & -3.81150400 & 3.68043100 \\
\hline $\mathrm{H}$ & -1.13060400 & -2.10038200 & 5.30315400 \\
\hline $\mathrm{H}$ & -1.61092500 & 0.21110500 & 4.52069600 \\
\hline $\mathrm{H}$ & -1.26778800 & 0.81491700 & 2.14778300 \\
\hline $\mathrm{H}$ & -1.82316000 & 2.76556700 & 0.94375300 \\
\hline $\mathrm{H}$ & -3.29850100 & 4.39041700 & 2.09635000 \\
\hline $\mathrm{H}$ & -5.76929200 & 4.05616200 & 2.05710800 \\
\hline $\mathrm{H}$ & -6.72485500 & 2.10956800 & 0.88373000 \\
\hline $\mathrm{H}$ & -2.59889100 & -0.40272200 & 0.19607200 \\
\hline $\mathrm{H}$ & -2.92463100 & 0.22277200 & -1.38653800 \\
\hline $\mathrm{H}$ & -5.13529700 & -4.92197500 & 0.14681500 \\
\hline $\mathrm{H}$ & -3.99016100 & -4.66734500 & 2.32993500 \\
\hline $\mathrm{H}$ & -3.56849400 & -2.38472500 & 3.24205200 \\
\hline $\mathrm{H}$ & -4.29461500 & -0.40546900 & 1.97389000 \\
\hline $\mathrm{H}$ & -6.03488600 & -4.06620400 & -1.81168400 \\
\hline $\mathrm{H}$ & -5.48885700 & -2.45475200 & -2.31616100 \\
\hline $\mathrm{H}$ & -7.04532500 & -2.64422000 & -1.52231500 \\
\hline $\mathrm{H}$ & 6.25705200 & -1.00954900 & -2.15891400 \\
\hline $\mathrm{H}$ & 8.22414900 & 0.47224300 & -2.33543700 \\
\hline $\mathrm{H}$ & 8.67922300 & 2.16552200 & -0.57844200 \\
\hline $\mathrm{H}$ & 7.11814500 & 2.39557600 & 1.34378800 \\
\hline $\mathrm{H}$ & 5.13820900 & 0.93684300 & 1.50850800 \\
\hline $\mathrm{H}$ & 2.46925200 & -1.96763500 & -2.34136400 \\
\hline $\mathrm{H}$ & 2.70159500 & -3.74354700 & -4.06050000 \\
\hline $\mathrm{H}$ & 4.63109400 & -5.31229800 & -3.96469700 \\
\hline $\mathrm{H}$ & 6.31961600 & -5.08611400 & -2.16127000 \\
\hline $\mathrm{H}$ & 6.09334400 & -3.29628700 & -0.46499200 \\
\hline $\mathrm{H}$ & 2.27353600 & -2.35908800 & 1.82267200 \\
\hline $\mathrm{H}$ & 2.57937000 & -3.48118100 & 4.00137600 \\
\hline $\mathrm{H}$ & 4.86367800 & -3.73501100 & 4.96202200 \\
\hline
\end{tabular}

$\begin{array}{lccc}\mathrm{H} & 6.82450700 & -2.85891600 & 3.71809100 \\ \mathrm{H} & 6.51559500 & -1.72430400 & 1.54717700 \\ \mathrm{C} & -7.31736900 & 0.11694600 & -0.50733500 \\ \mathrm{C} & -8.00085200 & 1.06630900 & -1.30163400 \\ \mathrm{C} & -9.38642100 & 1.18024900 & -1.16840300 \\ \mathrm{C} & -10.10188700 & 0.37708500 & -0.28569900 \\ \mathrm{C} & -9.42907400 & -0.55899600 & 0.49149800 \\ \mathrm{C} & -8.04742800 & -0.68172000 & 0.38100100 \\ \mathrm{C} & -7.26262900 & 1.96087100 & -2.24993800 \\ \mathrm{H} & -9.90967700 & 1.91536700 & -1.77724100 \\ \mathrm{H} & -11.18037700 & 0.48355700 & -0.20737600 \\ \mathrm{H} & -9.97416900 & -1.18957300 & 1.18872600 \\ \mathrm{H} & -7.52236800 & -1.40788400 & 0.99740700 \\ \mathrm{H} & -7.95136500 & 2.54846200 & -2.86189200 \\ \mathrm{H} & -6.60965500 & 1.38695700 & -2.91733600 \\ \mathrm{H} & -6.60975700 & 2.66196800 & -1.71496900\end{array}$

\section{Compound: 2[I-1a]}

Charge: 0

Multiplicity: 1

Lowest Frequency: $17.50 \mathrm{~cm}^{-1}$

Energy: -3672.807950 Hartree

$\begin{array}{cccc}\mathrm{Ni} & 0.05306600 & 0.70748700 & -0.21682900 \\ \mathrm{P} & -1.97929500 & -0.03886200 & -0.21923000 \\ \mathrm{P} & 1.98350400 & -0.10110700 & -0.27455700 \\ \mathrm{~N} & -0.54526500 & 2.07140800 & 0.86658900 \\ \mathrm{C} & -2.71334300 & 1.63181900 & -0.03696100 \\ \mathrm{C} & -4.00851900 & 2.03028100 & -0.35265000 \\ \mathrm{C} & -4.38577500 & 3.36810800 & -0.22194400 \\ \mathrm{C} & -3.45258500 & 4.30072700 & 0.22843900 \\ \mathrm{C} & -2.15629000 & 3.91828900 & 0.56353400 \\ \mathrm{C} & -1.77064600 & 2.57923200 & 0.43865000 \\ \mathrm{C} & 0.67550800 & 2.41895100 & 0.32788700 \\ \mathrm{C} & 1.92307400 & 2.25142400 & 1.14279100 \\ \mathrm{C} & 2.38586700 & 3.22048900 & 2.03644000 \\ \mathrm{C} & 3.57121900 & 3.02602700 & 2.73943500 \\ \mathrm{C} & 4.31719500 & 1.86270400 & 2.55327100 \\ \mathrm{C} & 3.87291800 & 0.89227600 & 1.66217400 \\ \mathrm{C} & 2.67998100 & 1.07924900 & 0.96035000 \\ \mathrm{C} & -2.47147800 & -0.98359200 & 1.26136800 \\ \mathrm{C} & -1.68380300 & -2.08170700 & 1.62888300 \\ \mathrm{C} & -2.01959600 & -2.84593800 & 2.74212000 \\ \mathrm{C} & -3.13670900 & -2.51154300 & 3.50450000 \\ \mathrm{C} & -3.91753100 & -1.41317300 & 3.15075000 \\ \mathrm{C} & -3.58943200 & -0.65277500 & 2.03237500 \\ \mathrm{C} & -2.93543500 & -0.79898600 & -1.57375700 \\ \mathrm{C} & -3.05170800 & -0.10383500 & -2.78555400 \\ \mathrm{C} & -3.70752500 & -0.67804200 & -3.86767200 \\ \mathrm{C} & -4.24952800 & -1.95828900 & -3.75997400 \\ \mathrm{C} & -4.13368400 & -2.65712400 & -2.56268600 \\ \mathrm{C} & -3.48273300 & -2.08218500 & -1.47446000 \\ \mathrm{C} & 2.17992800 & -1.72734500 & 0.53014500 \\ \mathrm{C} & 1.98027100 & -1.84616000 & 1.91246400 \\ \mathrm{C} & 1.94712000 & -3.09932200 & 2.51678000 \\ \mathrm{C} & 2.10308800 & -4.25184000 & 1.75034300 \\ \mathrm{C} & 2.29368500 & -4.14479700 & 0.37390800 \\ \mathrm{C} & 2.32758600 & -2.89382700 & -0.23265200\end{array}$




$\begin{array}{lrrr}\mathrm{C} & 3.22824300 & -0.09918600 & -1.61647000 \\ \mathrm{C} & 2.93921700 & 0.65498200 & -2.75878700 \\ \mathrm{C} & 3.86408400 & 0.75738900 & -3.79340900 \\ \mathrm{C} & 5.08674600 & 0.09826800 & -3.70088300 \\ \mathrm{C} & 5.38298200 & -0.66125200 & -2.57066500 \\ \mathrm{C} & 4.46170000 & -0.75725100 & -1.53304200 \\ \mathrm{H} & -4.71299200 & 1.29727800 & -0.74330000 \\ \mathrm{H} & -5.39116000 & 3.68078100 & -0.48722400 \\ \mathrm{H} & -3.73784400 & 5.34612200 & 0.31904400 \\ \mathrm{H} & -1.43614100 & 4.64518500 & 0.93110800 \\ \mathrm{H} & 0.70689200 & 3.22278300 & -0.42337700 \\ \mathrm{H} & 1.80334300 & 4.12748300 & 2.18438400 \\ \mathrm{H} & 3.91657000 & 3.78390300 & 3.43771600 \\ \mathrm{H} & 5.24199900 & 1.71437200 & 3.10432400 \\ \mathrm{H} & 4.44461300 & -0.02360200 & 1.52121800 \\ \mathrm{H} & -0.80122800 & -2.33088400 & 1.03956800 \\ \mathrm{H} & -1.39993300 & -3.69547700 & 3.01749800 \\ \mathrm{H} & -3.39514400 & -3.10220200 & 4.37908300 \\ \mathrm{H} & -4.78488500 & -1.14699400 & 3.74863100 \\ \mathrm{H} & -4.19319400 & 0.20979600 & 1.75882000 \\ \mathrm{H} & -2.63331700 & 0.89780700 & -2.86863800 \\ \mathrm{H} & -3.79665400 & -0.12520400 & -4.79905500 \\ \mathrm{H} & -4.76068900 & -2.40712900 & -4.60710300 \\ \mathrm{H} & -4.55722800 & -3.65362100 & -2.46982000 \\ \mathrm{H} & -3.40387700 & -2.63306400 & -0.54008400 \\ \mathrm{H} & 1.83827300 & -0.94974200 & 2.51261300 \\ \mathrm{H} & 1.79326200 & -3.17374600 & 3.59021300 \\ \mathrm{H} & 2.07455600 & -5.23003500 & 2.22268000 \\ \mathrm{H} & 2.41390200 & -5.03979600 & -0.23068000 \\ \mathrm{H} & 2.46958600 & -2.81876800 & -1.30875000 \\ \mathrm{H} & 1.97601900 & 1.15833800 & -2.83010500 \\ \mathrm{H} & 3.62697900 & 1.34636100 & -4.67495800 \\ \mathrm{H} & 5.80842200 & 0.17288900 & -4.50973000 \\ \mathrm{H} & 6.33587500 & -1.17866900 & -2.49672700 \\ \mathrm{H} & 4.69731700 & -1.35640500 & -0.65568600 \\ & & & \end{array}$

\begin{tabular}{|c|c|c|c|}
\hline \multicolumn{4}{|c|}{ Compound: $2[\mathrm{I}-1 \mathrm{~b}]$} \\
\hline \multicolumn{4}{|c|}{ Charge: 0} \\
\hline \multicolumn{4}{|c|}{ Multiplicity: 1} \\
\hline \multicolumn{4}{|c|}{ Lowest Frequency: $15.55 \mathrm{~cm}^{-1}$} \\
\hline \multicolumn{4}{|c|}{ Energy: -4709.078235 Hartree } \\
\hline $\mathrm{Ni}$ & 0.85708600 & 0.72683300 & -0.40783000 \\
\hline $\mathrm{P}$ & 2.89410500 & 1.21260200 & 0.12892500 \\
\hline $\mathrm{P}$ & -3.45952800 & 0.78680000 & 0.61012300 \\
\hline $\mathrm{P}$ & 0.53745400 & -1.36963200 & -0.22016500 \\
\hline $\mathrm{N}$ & 0.53303800 & 2.52405400 & -0.60066600 \\
\hline $\mathrm{C}$ & 2.51945800 & 2.90096000 & 0.69889100 \\
\hline $\mathrm{C}$ & 3.31085300 & 3.70997600 & 1.51217300 \\
\hline $\mathrm{C}$ & 2.81877500 & 4.92773400 & 1.97643100 \\
\hline $\mathrm{C}$ & 1.52561100 & 5.32147600 & 1.62591600 \\
\hline $\mathrm{C}$ & 0.72851500 & 4.53133900 & 0.80522600 \\
\hline $\mathrm{C}$ & 1.22168000 & 3.31237900 & 0.31976500 \\
\hline $\mathrm{C}$ & -0.68213300 & 1.92821200 & -0.31338600 \\
\hline $\mathrm{C}$ & -1.73181500 & 1.89125700 & -1.34442500 \\
\hline $\mathrm{C}$ & -1.44526100 & 2.34870800 & -2.64408600 \\
\hline $\mathrm{C}$ & -2.40088600 & 2.32454700 & -3.64687400 \\
\hline $\mathrm{C}$ & -3.69177800 & 1.86817900 & -3.37535700 \\
\hline $\mathrm{C}$ & -3.99740300 & 1.43070600 & -2.09333400 \\
\hline
\end{tabular}

\begin{tabular}{|c|c|c|c|}
\hline $\mathrm{C}$ & -3.03368200 & 1.40356500 & -1.07348600 \\
\hline $\mathrm{C}$ & 4.27659700 & 1.30143300 & -1.04453200 \\
\hline $\mathrm{C}$ & 4.75957500 & 0.09763500 & -1.57924600 \\
\hline $\mathrm{C}$ & 5.76230700 & 0.10712500 & -2.54045600 \\
\hline $\mathrm{C}$ & 6.28125400 & 1.31868200 & -2.99571800 \\
\hline $\mathrm{C}$ & 5.79508500 & 2.51764400 & -2.48131900 \\
\hline $\mathrm{C}$ & 4.79872300 & 2.51283100 & -1.50816900 \\
\hline $\mathrm{C}$ & 3.55357800 & 0.39335400 & 1.62169200 \\
\hline $\mathrm{C}$ & 2.65397600 & 0.23596900 & 2.68683200 \\
\hline $\mathrm{C}$ & 3.00125200 & -0.50669000 & 3.80741700 \\
\hline $\mathrm{C}$ & 4.26660200 & -1.08924800 & 3.89151500 \\
\hline $\mathrm{C}$ & 5.17852700 & -0.90821000 & 2.85616200 \\
\hline $\mathrm{C}$ & 4.82532000 & -0.17535400 & 1.72383300 \\
\hline $\mathrm{C}$ & -3.78610900 & -1.00789900 & 0.37458200 \\
\hline $\mathrm{C}$ & -4.14054000 & -1.61743900 & -0.83447700 \\
\hline $\mathrm{C}$ & -4.44664200 & -2.97392900 & -0.87869700 \\
\hline $\mathrm{C}$ & -4.38570400 & -3.75090600 & 0.27567300 \\
\hline $\mathrm{C}$ & -4.02150400 & -3.16121900 & 1.48241500 \\
\hline $\mathrm{C}$ & -3.73106000 & -1.80111000 & 1.52899000 \\
\hline $\mathrm{C}$ & -5.17315200 & 1.43939800 & 0.76462300 \\
\hline $\mathrm{C}$ & -5.34830200 & 2.82880300 & 0.67165600 \\
\hline $\mathrm{C}$ & -6.59934300 & 3.40456700 & 0.85232600 \\
\hline $\mathrm{C}$ & -7.70318200 & 2.60412600 & 1.14302300 \\
\hline $\mathrm{C}$ & -7.54129200 & 1.22642700 & 1.24533400 \\
\hline $\mathrm{C}$ & -6.28786700 & 0.64599700 & 1.05720200 \\
\hline $\mathrm{C}$ & 2.04155500 & -2.36823000 & -0.55698700 \\
\hline $\mathrm{C}$ & 2.97544600 & -2.64160000 & 0.45072300 \\
\hline $\mathrm{C}$ & 4.17705400 & -3.27755400 & 0.14888700 \\
\hline $\mathrm{C}$ & 4.47046500 & -3.64008300 & -1.16333300 \\
\hline $\mathrm{C}$ & 3.55384400 & -3.36011100 & -2.17555900 \\
\hline $\mathrm{C}$ & 2.35161200 & -2.72741700 & -1.87637000 \\
\hline $\mathrm{C}$ & 0.01944800 & -1.93609600 & 1.43963000 \\
\hline $\mathrm{C}$ & -0.55834400 & -0.98931700 & 2.29307200 \\
\hline $\mathrm{C}$ & -0.93994800 & -1.33623000 & 3.58597000 \\
\hline $\mathrm{C}$ & -0.75485700 & -2.63952400 & 4.03890900 \\
\hline $\mathrm{C}$ & -0.18687400 & -3.59358900 & 3.19600400 \\
\hline $\mathrm{C}$ & 0.20041500 & -3.24377700 & 1.90606200 \\
\hline $\mathrm{C}$ & -0.61804100 & -2.10653800 & -1.43190800 \\
\hline $\mathrm{C}$ & -1.04771100 & -1.28516100 & -2.47761000 \\
\hline $\mathrm{C}$ & -1.82055300 & -1.80220100 & -3.51432200 \\
\hline $\mathrm{C}$ & -2.16107000 & -3.15145000 & -3.51453100 \\
\hline $\mathrm{C}$ & -1.74341500 & -3.97686000 & -2.46988000 \\
\hline $\mathrm{C}$ & -0.98219700 & -3.45743100 & -1.42996700 \\
\hline $\mathrm{H}$ & 4.29963700 & 3.36529100 & 1.81192800 \\
\hline $\mathrm{H}$ & 3.42630300 & 5.55335800 & 2.62297900 \\
\hline $\mathrm{H}$ & 1.13132500 & 6.26288500 & 2.00053900 \\
\hline $\mathrm{H}$ & -0.27180000 & 4.84855500 & 0.52189200 \\
\hline $\mathrm{H}$ & -1.05815400 & 2.00451500 & 0.71567900 \\
\hline $\mathrm{H}$ & -0.44743600 & 2.73607800 & -2.83205500 \\
\hline $\mathrm{H}$ & -2.14726300 & 2.68514400 & -4.64103700 \\
\hline $\mathrm{H}$ & -4.45439600 & 1.86831300 & -4.14944200 \\
\hline $\mathrm{H}$ & -5.01139100 & 1.10848300 & -1.86350500 \\
\hline $\mathrm{H}$ & 4.34432400 & -0.84801900 & -1.23437200 \\
\hline $\mathrm{H}$ & 6.13162100 & -0.83401000 & -2.94054900 \\
\hline $\mathrm{H}$ & 7.05910600 & 1.32774400 & -3.75437700 \\
\hline $\mathrm{H}$ & 6.19347300 & 3.46361500 & -2.83784200 \\
\hline $\mathrm{H}$ & 4.41888700 & 3.45017600 & -1.10899300 \\
\hline $\mathrm{H}$ & 1.66580900 & 0.69099200 & 2.62227500 \\
\hline
\end{tabular}




$\begin{array}{lrrr}\mathrm{H} & 2.27988700 & -0.63793400 & 4.60967200 \\ \mathrm{H} & 4.53994300 & -1.67642900 & 4.76360200 \\ \mathrm{H} & 6.17088900 & -1.34735700 & 2.92176300 \\ \mathrm{H} & 5.53764600 & -0.06238100 & 0.91020600 \\ \mathrm{H} & -4.16689800 & -1.03370600 & -1.75041100 \\ \mathrm{H} & -4.72020100 & -3.42935700 & -1.82721800 \\ \mathrm{H} & -4.61434400 & -4.81269100 & 0.23181900 \\ \mathrm{H} & -3.95509300 & -3.75719100 & 2.38927700 \\ \mathrm{H} & -3.45094500 & -1.34285400 & 2.47493100 \\ \mathrm{H} & -4.49226200 & 3.46038000 & 0.43962400 \\ \mathrm{H} & -6.71389000 & 4.48198200 & 0.76658700 \\ \mathrm{H} & -8.68206200 & 3.05290800 & 1.28671200 \\ \mathrm{H} & -8.39655300 & 0.59292100 & 1.46650000 \\ \mathrm{H} & -6.18108600 & -0.43378200 & 1.12989700 \\ \mathrm{H} & 2.76475800 & -2.35188800 & 1.47829500 \\ \mathrm{H} & 4.88785500 & -3.47881400 & 0.94649300 \\ \mathrm{H} & 5.40956300 & -4.13457000 & -1.39688300 \\ \mathrm{H} & 3.77678700 & -3.63214500 & -3.20380500 \\ \mathrm{H} & 1.64453300 & -2.51068400 & -2.67417700 \\ \mathrm{H} & -0.71032400 & 0.02666000 & 1.92858500 \\ \mathrm{H} & -1.38643000 & -0.58618800 & 4.23405100 \\ \mathrm{H} & -1.04702500 & -2.91251400 & 5.04943900 \\ \mathrm{H} & -0.03635800 & -4.61066100 & 3.54780800 \\ \mathrm{H} & 0.67539300 & -3.98427300 & 1.26584800 \\ \mathrm{H} & -0.75996600 & -0.23556800 & -2.46948100 \\ \mathrm{H} & -2.15390000 & -1.14525400 & -4.31379600 \\ \mathrm{H} & -2.75873200 & -3.56277300 & -4.32418400 \\ \mathrm{H} & -2.02309300 & -5.02725200 & -2.46174000 \\ \mathrm{H} & -0.66946800 & -4.10510300 & -0.61332600 \\ & & & \\ & & \end{array}$

\section{Compound: 2[I-2]}

Charge: 0

Multiplicity: 1

Lowest Frequency: $17.73 \mathrm{~cm}^{-1}$

Energy: -4426.793585 Hartree

$\begin{array}{lrrr}\mathrm{P} & 0.97117000 & 1.56406500 & -0.11571700 \\ \mathrm{P} & -2.09663500 & -0.59410300 & 0.29156900 \\ \mathrm{~N} & -0.79990200 & 1.25949300 & 2.09296200 \\ \mathrm{C} & 0.83696800 & 2.79545800 & 1.22472600 \\ \mathrm{C} & 1.57520100 & 3.97420000 & 1.33495800 \\ \mathrm{C} & 1.51633700 & 4.73572000 & 2.49839500 \\ \mathrm{C} & 0.72491400 & 4.29932800 & 3.56248000 \\ \mathrm{C} & -0.02080400 & 3.13049000 & 3.46989200 \\ \mathrm{C} & 0.02284700 & 2.36526300 & 2.29540500 \\ \mathrm{C} & -0.71758000 & 0.10933200 & 2.81462200 \\ \mathrm{C} & -1.96280600 & -0.66038400 & 3.03352800 \\ \mathrm{C} & -2.35186700 & -1.04285400 & 4.31978300 \\ \mathrm{C} & -3.54712600 & -1.72504900 & 4.52421900 \\ \mathrm{C} & -4.37399600 & -2.02874700 & 3.44517000 \\ \mathrm{C} & -3.99012700 & -1.66351800 & 2.15687400 \\ \mathrm{C} & -2.78102200 & -1.00493200 & 1.94155000 \\ \mathrm{C} & 0.23291700 & 2.25286900 & -1.63286100 \\ \mathrm{C} & -0.16995100 & 1.33061600 & -2.60923900 \\ \mathrm{C} & -0.77562500 & 1.76949700 & -3.78142500 \\ \mathrm{C} & -1.00213200 & 3.12973800 & -3.98358900 \\ \mathrm{C} & -0.61388600 & 4.05030300 & -3.01284400 \\ \mathrm{C} & 0.00647200 & 3.61595600 & -1.84397800\end{array}$

\begin{tabular}{|c|c|c|c|}
\hline C & 2.76433000 & 1.55907000 & -0.46112900 \\
\hline $\mathrm{C}$ & 3.60692800 & 1.00368900 & 0.51154400 \\
\hline $\mathrm{C}$ & 4.96738600 & 0.86033500 & 0.27084700 \\
\hline $\mathrm{C}$ & 5.50821600 & 1.28236100 & -0.94349600 \\
\hline $\mathrm{C}$ & 4.68235000 & 1.85542400 & -1.90642300 \\
\hline $\mathrm{C}$ & 3.31598000 & 1.99174000 & -1.67029200 \\
\hline $\mathrm{C}$ & -3.20980700 & 0.73202900 & -0.32298800 \\
\hline $\mathrm{C}$ & -2.78597700 & 2.06382500 & -0.28946300 \\
\hline $\mathrm{C}$ & -3.61878700 & 3.08394900 & -0.73835300 \\
\hline $\mathrm{C}$ & -4.89061600 & 2.78907900 & -1.21890400 \\
\hline $\mathrm{C}$ & -5.33037900 & 1.46756000 & -1.24305700 \\
\hline $\mathrm{C}$ & -4.49713000 & 0.44714300 & -0.79754400 \\
\hline $\mathrm{C}$ & -2.56491200 & -2.02303000 & -0.73701600 \\
\hline $\mathrm{C}$ & -2.81787200 & -1.86840100 & -2.10743900 \\
\hline $\mathrm{C}$ & -3.03220400 & -2.97849300 & -2.91749400 \\
\hline $\mathrm{C}$ & -2.97382600 & -4.26203300 & -2.37898900 \\
\hline $\mathrm{C}$ & -2.70658800 & -4.42811600 & -1.02170100 \\
\hline $\mathrm{C}$ & -2.50433900 & -3.31914700 & -0.20640000 \\
\hline $\mathrm{H}$ & 2.23473500 & 4.26719300 & 0.51913500 \\
\hline $\mathrm{H}$ & 2.10235200 & 5.64533000 & 2.58775800 \\
\hline $\mathrm{H}$ & 0.69279700 & 4.87795400 & 4.48215900 \\
\hline $\mathrm{H}$ & -0.64980500 & 2.80088700 & 4.29283900 \\
\hline $\mathrm{H}$ & 0.03717900 & 0.03714600 & 3.60877300 \\
\hline $\mathrm{H}$ & -1.71262500 & -0.79142400 & 5.16356500 \\
\hline $\mathrm{H}$ & -3.83573100 & -2.01963700 & 5.52954600 \\
\hline $\mathrm{H}$ & -5.30694500 & -2.56230100 & 3.60357400 \\
\hline $\mathrm{H}$ & -4.61333200 & -1.93320800 & 1.30623200 \\
\hline $\mathrm{H}$ & -0.01497600 & 0.26288400 & -2.44240000 \\
\hline $\mathrm{H}$ & -1.08012200 & 1.04314000 & -4.53148600 \\
\hline $\mathrm{H}$ & -1.48873400 & 3.47226100 & -4.89276600 \\
\hline $\mathrm{H}$ & -0.79721500 & 5.11094000 & -3.16436800 \\
\hline $\mathrm{H}$ & 0.29426400 & 4.33484100 & -1.07875300 \\
\hline $\mathrm{H}$ & 3.18357900 & 0.65514200 & 1.45241300 \\
\hline $\mathrm{H}$ & 5.60206700 & 0.40573500 & 1.02689400 \\
\hline $\mathrm{H}$ & 6.57042600 & 1.16209400 & -1.13755200 \\
\hline $\mathrm{H}$ & 5.09949600 & 2.19060200 & -2.85257300 \\
\hline $\mathrm{H}$ & 2.67249000 & 2.41401000 & -2.43851700 \\
\hline $\mathrm{H}$ & -1.79945500 & 2.30121300 & 0.09488000 \\
\hline $\mathrm{H}$ & -3.26454100 & 4.11122200 & -0.71621100 \\
\hline $\mathrm{H}$ & -5.53960900 & 3.58571700 & -1.57261300 \\
\hline $\mathrm{H}$ & -6.32452900 & 1.22876800 & -1.61153700 \\
\hline $\mathrm{H}$ & -4.84390300 & -0.58318600 & -0.83481700 \\
\hline $\mathrm{H}$ & -2.84308400 & -0.87023200 & -2.54058100 \\
\hline $\mathrm{H}$ & -3.23475600 & -2.83940200 & -3.97641500 \\
\hline $\mathrm{H}$ & -3.13484900 & -5.12880300 & -3.01389800 \\
\hline $\mathrm{H}$ & -2.65356300 & -5.42556800 & -0.59425400 \\
\hline $\mathrm{H}$ & -2.29297400 & -3.45691100 & 0.85113300 \\
\hline $\mathrm{Ni}$ & -0.00870000 & -0.10659600 & 0.94187500 \\
\hline $\mathrm{Si}$ & 1.15819200 & -2.03149000 & 0.38638100 \\
\hline $\mathrm{H}$ & 1.23416600 & -0.73507300 & 1.51759800 \\
\hline $\mathrm{H}$ & 0.26321600 & -3.18494300 & 0.70385500 \\
\hline $\mathrm{C}$ & 1.35155600 & -1.96278000 & -1.48970400 \\
\hline $\mathrm{C}$ & 2.41986600 & -1.27227300 & -2.08912200 \\
\hline $\mathrm{C}$ & 0.39202000 & -2.53472500 & -2.33964000 \\
\hline $\mathrm{C}$ & 2.49861100 & -1.11763400 & -3.47008900 \\
\hline $\mathrm{H}$ & 3.21007600 & -0.85824100 & -1.46576100 \\
\hline $\mathrm{C}$ & 0.46745500 & -2.38405300 & -3.72285600 \\
\hline $\mathrm{H}$ & -0.42224500 & -3.11689700 & -1.91511200 \\
\hline
\end{tabular}




$\begin{array}{lrrr}\mathrm{C} & 1.51368700 & -1.66176900 & -4.29223600 \\ \mathrm{H} & 3.33255000 & -0.57043800 & -3.90411100 \\ \mathrm{H} & -0.29439600 & -2.83701600 & -4.35413800 \\ \mathrm{H} & 1.57029900 & -1.53632500 & -5.37062100 \\ \mathrm{C} & 2.88684700 & -2.46278600 & 1.04701000 \\ \mathrm{C} & 3.33026000 & -2.05261200 & 2.31325200 \\ \mathrm{C} & 3.76987100 & -3.23427700 & 0.27578200 \\ \mathrm{C} & 4.59162100 & -2.39493400 & 2.79246500 \\ \mathrm{H} & 2.67501900 & -1.44063900 & 2.93526200 \\ \mathrm{C} & 5.03537900 & -3.57706400 & 0.74273400 \\ \mathrm{H} & 3.46479500 & -3.56156200 & -0.71692700 \\ \mathrm{C} & 5.44988000 & -3.15864100 & 2.00456900 \\ \mathrm{H} & 4.90795600 & -2.06217300 & 3.77825400 \\ \mathrm{H} & 5.70053300 & -4.17051900 & 0.12039200 \\ \mathrm{H} & 6.43837700 & -3.42323600 & 2.37161100\end{array}$

\section{Compound: 2[I-3a]}

Charge: 0

Multiplicity: 1

Lowest Frequency: $16.50 \mathrm{~cm}^{-1}$

Energy: -4426.820035 Hartree

$\begin{array}{lrrr}\mathrm{P} & -1.44536000 & 1.33420000 & 0.01098100 \\ \mathrm{P} & 2.16252400 & -0.51476800 & -0.12873500 \\ \mathrm{~N} & 0.81618600 & 1.75044900 & -1.55066600 \\ \mathrm{C} & -1.14362000 & 2.89913900 & -0.81761300 \\ \mathrm{C} & -1.97769800 & 4.01192800 & -0.76651300 \\ \mathrm{C} & -1.56750800 & 5.22501300 & -1.30922500 \\ \mathrm{C} & -0.29319400 & 5.30058700 & -1.87665600 \\ \mathrm{C} & 0.54842800 & 4.19950400 & -1.94250300 \\ \mathrm{C} & 0.13074100 & 2.93781100 & -1.45365800 \\ \mathrm{C} & 2.19910200 & 1.80543000 & -2.01007700 \\ \mathrm{C} & 3.15980400 & 1.96548900 & -0.85841200 \\ \mathrm{C} & 3.92606300 & 3.11703600 & -0.70057700 \\ \mathrm{C} & 4.77006900 & 3.27145800 & 0.39760500 \\ \mathrm{C} & 4.86233400 & 2.26067700 & 1.34725500 \\ \mathrm{C} & 4.10411600 & 1.09945800 & 1.20266400 \\ \mathrm{C} & 3.24652600 & 0.94523600 & 0.11120500 \\ \mathrm{C} & -1.02429700 & 1.60917800 & 1.76540900 \\ \mathrm{C} & -1.47279100 & 0.72685100 & 2.75875600 \\ \mathrm{C} & -1.03402900 & 0.86771800 & 4.07138700 \\ \mathrm{C} & -0.12386200 & 1.86796800 & 4.40609300 \\ \mathrm{C} & 0.34526100 & 2.73332400 & 3.41833800 \\ \mathrm{C} & -0.10214300 & 2.61020300 & 2.10662200 \\ \mathrm{C} & -3.23224900 & 1.04102300 & -0.09652000 \\ \mathrm{C} & -3.71600400 & 0.57300300 & -1.32628700 \\ \mathrm{C} & -5.06829500 & 0.29880400 & -1.49227100 \\ \mathrm{C} & -5.95476800 & 0.49679600 & -0.43488500 \\ \mathrm{C} & -5.48585100 & 0.98845900 & 0.78049200 \\ \mathrm{C} & -4.13122500 & 1.26207000 & 0.95104900 \\ \mathrm{C} & 2.24160800 & -1.38969900 & 1.46580800 \\ \mathrm{C} & 1.78482400 & -0.71075000 & 2.60468900 \\ \mathrm{C} & 1.75007100 & -1.35290800 & 3.83622500 \\ \mathrm{C} & 2.14997800 & -2.68466300 & 3.94308500 \\ \mathrm{C} & 2.58334000 & -3.37062700 & 2.81215100 \\ \mathrm{C} & 2.63174100 & -2.72773000 & 1.57656500 \\ \mathrm{C} & 3.11740900 & -1.55014600 & -1.29294500 \\ \mathrm{C} & 2.47053800 & -2.16461700 & -2.37041300\end{array}$

$3.19022500 \quad-2.94607900 \quad-3.27028000$

$\begin{array}{lll}4.56071600 & -3.12019100 & -3.10118000\end{array}$

$\begin{array}{lll}5.21453500 & -2.50914100 & -2.03224200\end{array}$

$\begin{array}{llll}4.49802900 & -1.72696600 & -1.13403300\end{array}$

$\begin{array}{llll}-2.94924000 & 3.92406500 & -0.28146300\end{array}$

$\begin{array}{llll}-2.21113100 & 6.09772200 & -1.26998000\end{array}$

$\begin{array}{llll}0.05917000 & 6.24874000 & -2.27691700\end{array}$

$\begin{array}{llll}1.53007500 & 4.32004000 & -2.38902300\end{array}$

$\begin{array}{lll}2.36398800 & 2.60119100 & -2.74681500\end{array}$

$\begin{array}{llll}3.85418500 & 3.90424000 & -1.44882300\end{array}$

$\begin{array}{llll}5.35287300 & 4.18171800 & 0.51017000\end{array}$

$\begin{array}{lll}5.52230100 & 2.37032300 & 2.20333600\end{array}$

$\begin{array}{lll}4.17890900 & 0.31226300 & 1.94908700\end{array}$

$\begin{array}{lll}-2.16257200 & -0.07433100 & 2.50593100\end{array}$

$\begin{array}{llll}-1.39834200 & 0.17658900 & 4.82786600\end{array}$

$\begin{array}{lll}0.22335400 & 1.97062700 & 5.43103500\end{array}$

$\begin{array}{lll}1.06102400 & 3.51149700 & 3.66900200\end{array}$

$\begin{array}{lll}0.27100400 & 3.28503400 & 1.33834800\end{array}$

$\begin{array}{llll}-3.02303300 & 0.40438700 & -2.14772300\end{array}$

$\begin{array}{llll}-5.42592500 & -0.07974200 & -2.44587300\end{array}$

$\begin{array}{lll}-7.01075500 & 0.27323100 & -0.56017000\end{array}$

$\begin{array}{lll}-6.17598100 & 1.15654700 & 1.60305000\end{array}$

$\begin{array}{lll}-3.77229600 & 1.63823700 & 1.90536400\end{array}$

$\begin{array}{lll}1.45253600 & 0.32473200 & 2.52292300\end{array}$

$\begin{array}{lll}1.39532100 & -0.81184500 & 4.70985400\end{array}$

$\begin{array}{llll}2.11398400 & -3.18896400 & 4.90510400\end{array}$

$\begin{array}{llll}2.88266000 & -4.41236000 & 2.88680800\end{array}$

$\begin{array}{llll}2.96443100 & -3.26948900 & 0.69464500\end{array}$

$\begin{array}{lll}1.39778600 & -2.03012600 & -2.50561600\end{array}$

$\begin{array}{lll}2.67641800 & -3.41811300 & -4.10258500\end{array}$

$\begin{array}{llll}5.12256700 & -3.72865300 & -3.80449200\end{array}$

$\begin{array}{llll}6.28531700 & -2.63892100 & -1.90173300\end{array}$

$\begin{array}{llll}5.01099700 & -1.24186100 & -0.30543600\end{array}$

$\begin{array}{llll}0.23061700 & 0.18234800 & -0.63809100\end{array}$

$\begin{array}{llll}-0.66343700 & -1.85927700 & -0.41407100\end{array}$

$\begin{array}{llll}2.41661700 & 0.86530500 & -2.53757400\end{array}$

$\begin{array}{llll}0.37751200 & -2.94201100 & -0.33559300\end{array}$

$\begin{array}{lll}-1.78004100 & -2.27715800 & 1.04713200\end{array}$

$\begin{array}{lll}-3.16514900 & -2.04838600 & 1.09348300\end{array}$

$\begin{array}{lll}-1.15605700 & -2.71807500 & 2.22694200\end{array}$

$\begin{array}{lll}-3.88757600 & -2.22818900 & 2.27194700\end{array}$

$\begin{array}{lll}-3.68982800 & -1.71347500 & 0.19956900\end{array}$

$\begin{array}{lll}-1.86893300 & -2.88832200 & 3.40877800\end{array}$

$\begin{array}{lll}-0.08633700 & -2.92301700 & 2.21565700\end{array}$

$\begin{array}{llll}-3.23979800 & -2.63547600 & 3.43691400\end{array}$

$\begin{array}{lll}-4.95861700 & -2.03760400 & 2.27998500\end{array}$

$\begin{array}{llll}-1.35198200 & -3.21603100 & 4.30889500\end{array}$

$\begin{array}{lll}-3.80234000 & -2.76455000 & 4.35839700\end{array}$

$-1.60100500 \quad-2.07925200 \quad-2.04875600$

$\begin{array}{llll}-1.24907000 & -1.30231800 & -3.16664600\end{array}$

$-2.69189300 \quad-2.95051500 \quad-2.18486900$

$\begin{array}{llll}-1.94905500 & -1.39101300 & -4.36696000\end{array}$

$-0.42451900 \quad-0.58743200 \quad-3.08245900$

$\begin{array}{lll}-3.40369900 & -3.03886000 & -3.37914400\end{array}$

$\begin{array}{llll}-2.99712200 & -3.56026100 & -1.33570100\end{array}$

$-3.03439600 \quad-2.25851300 \quad-4.47260800$

$\begin{array}{lll}-1.65736700 & -0.77543100 & -5.21410600\end{array}$

$-4.25110300 \quad-3.71604000 \quad-3.45678100$ 
Compound: 2[I-3b]

Charge: 0

Multiplicity: 1

Lowest Frequency: $25.82 \mathrm{~cm}^{-1}$

Energy: -4426.770117 Hartree

\begin{tabular}{|c|c|c|c|}
\hline $\mathrm{Ni}$ & 0.22065800 & 0.20268700 & -0.68836600 \\
\hline$P$ & 2.33891700 & 0.22088300 & -0.37974000 \\
\hline$P$ & -0.94771700 & -1.49529000 & -0.01472600 \\
\hline $\mathrm{Si}$ & -1.47413000 & 1.74227900 & -0.18394500 \\
\hline $\mathrm{N}$ & -1.18271600 & 1.25681500 & 1.53709700 \\
\hline $\mathrm{C}$ & 2.37323300 & -0.09302200 & 1.42205700 \\
\hline $\mathrm{C}$ & 1.18212700 & 0.33854900 & 2.03845700 \\
\hline $\mathrm{C}$ & 1.00509500 & 0.11250200 & 3.40326600 \\
\hline $\mathrm{C}$ & 1.99076300 & -0.56107900 & 4.12757000 \\
\hline $\mathrm{C}$ & 3.16789200 & -0.98055100 & 3.51264100 \\
\hline $\mathrm{C}$ & 3.36951500 & -0.72765400 & 2.15424800 \\
\hline $\mathrm{C}$ & 0.23954900 & 1.04889600 & 1.12963400 \\
\hline $\mathrm{C}$ & 3.48201400 & -0.99677600 & -1.10461500 \\
\hline $\mathrm{C}$ & 2.95389300 & -2.18841800 & -1.60969200 \\
\hline $\mathrm{C}$ & 3.79813700 & -3.17806400 & -2.10278700 \\
\hline $\mathrm{C}$ & 5.17626600 & -2.97983300 & -2.10966200 \\
\hline $\mathrm{C}$ & 5.71058900 & -1.79018600 & -1.61865000 \\
\hline $\mathrm{C}$ & 4.86910000 & -0.80304400 & -1.11497000 \\
\hline $\mathrm{C}$ & 3.19548900 & 1.81886000 & -0.58860500 \\
\hline $\mathrm{C}$ & 3.45523100 & 2.67369800 & 0.48780500 \\
\hline $\mathrm{C}$ & 3.98413200 & 3.94361600 & 0.26466900 \\
\hline $\mathrm{C}$ & 4.26382300 & 4.36913100 & -1.02975500 \\
\hline $\mathrm{C}$ & 4.00531100 & 3.52358100 & -2.10935000 \\
\hline $\mathrm{C}$ & 3.46692100 & 2.26179700 & -1.89183800 \\
\hline $\mathrm{C}$ & -1.75300900 & -1.19473400 & 1.58678300 \\
\hline $\mathrm{C}$ & -1.84109500 & 0.12464500 & 2.08655000 \\
\hline $\mathrm{C}$ & -2.60732000 & 0.35132000 & 3.23925800 \\
\hline $\mathrm{C}$ & -3.24123200 & -0.68914700 & 3.90380700 \\
\hline $\mathrm{C}$ & -3.11158800 & -1.99792100 & 3.44017200 \\
\hline $\mathrm{C}$ & -2.37585500 & -2.23736200 & 2.28726100 \\
\hline $\mathrm{C}$ & -2.29521500 & -2.03611300 & -1.12980200 \\
\hline $\mathrm{C}$ & -1.97210000 & -2.23908300 & -2.48000000 \\
\hline $\mathrm{C}$ & -2.94468400 & -2.63263200 & -3.39204800 \\
\hline $\mathrm{C}$ & -4.26252100 & -2.80605500 & -2.97658500 \\
\hline $\mathrm{C}$ & -4.59862600 & -2.57745400 & -1.64575700 \\
\hline $\mathrm{C}$ & -3.62427400 & -2.19722000 & -0.72659700 \\
\hline $\mathrm{C}$ & 0.01736900 & -3.02354500 & 0.28814100 \\
\hline $\mathrm{C}$ & 0.07093600 & -4.08682400 & -0.62066600 \\
\hline $\mathrm{C}$ & 0.92922100 & -5.16169900 & -0.39964000 \\
\hline $\mathrm{C}$ & 1.74727700 & -5.19066200 & 0.72622200 \\
\hline $\mathrm{C}$ & 1.68814900 & -4.14428600 & 1.64366400 \\
\hline $\mathrm{C}$ & 0.83042100 & -3.07249800 & 1.43008000 \\
\hline $\mathrm{C}$ & -1.10319000 & 3.58220500 & -0.16066300 \\
\hline $\mathrm{C}$ & -1.92778200 & 4.47371700 & 0.54110800 \\
\hline $\mathrm{C}$ & -1.63442400 & 5.83213000 & 0.59731600 \\
\hline $\mathrm{C}$ & -0.50008400 & 6.32587300 & -0.04447800 \\
\hline $\mathrm{C}$ & 0.33542900 & 5.45780700 & -0.74191800 \\
\hline $\mathrm{C}$ & 0.03056400 & 4.10019300 & -0.80176200 \\
\hline $\mathrm{H}$ & -0.55140200 & 1.40314100 & -1.45875900 \\
\hline $\mathrm{H}$ & 0.09347300 & 0.44447000 & 3.89258000 \\
\hline
\end{tabular}

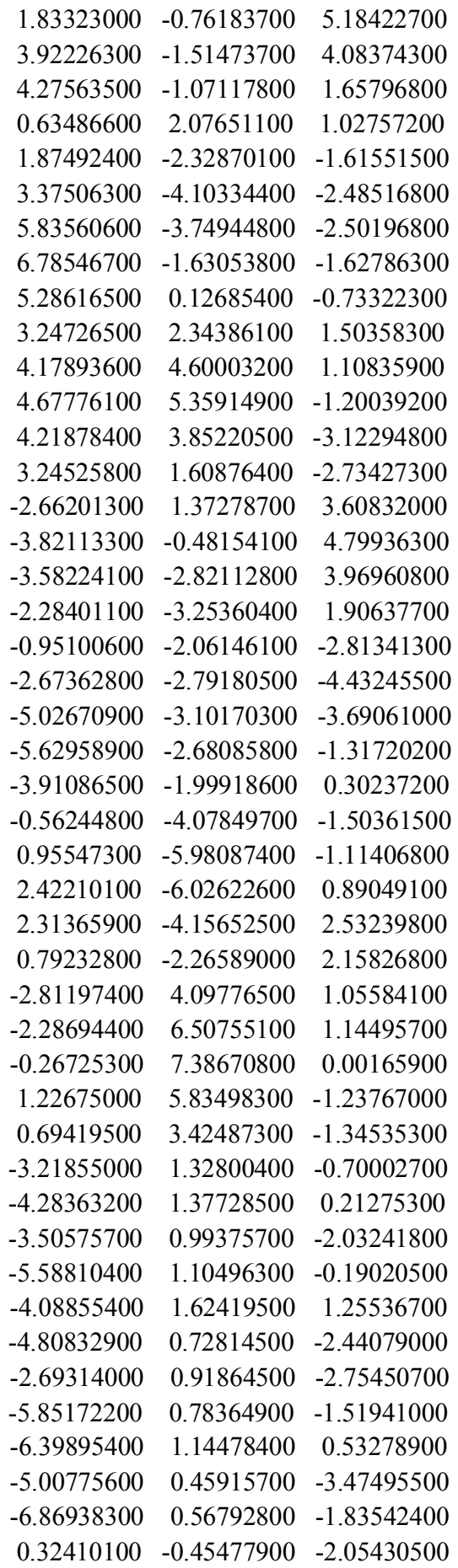




\begin{tabular}{|c|c|c|c|}
\hline $\mathrm{C}$ & -1.33902500 & 0.54310900 & 1.93506000 \\
\hline $\mathrm{C}$ & -3.68734500 & -0.22921400 & 3.27768900 \\
\hline $\mathrm{H}$ & -4.04003000 & -1.49510000 & 1.57708800 \\
\hline $\mathrm{C}$ & -1.65040600 & 1.06151400 & 3.20023000 \\
\hline $\mathrm{C}$ & -2.80740800 & 0.67757800 & 3.86442900 \\
\hline $\mathrm{H}$ & -4.60203900 & -0.51929400 & 3.78628200 \\
\hline $\mathrm{H}$ & -1.00165500 & 1.80373400 & 3.65512700 \\
\hline $\mathrm{H}$ & -3.03090900 & 1.10596900 & 4.83794800 \\
\hline $\mathrm{C}$ & 0.97714600 & 1.25346700 & 2.09290500 \\
\hline $\mathrm{H}$ & 1.07794700 & 0.35164600 & 2.71675900 \\
\hline $\mathrm{H}$ & 0.76894000 & 2.08432400 & 2.78206700 \\
\hline $\mathrm{C}$ & 2.94700700 & 0.77117800 & 0.46718700 \\
\hline $\mathrm{C}$ & 2.31025500 & 1.56292500 & 1.45182500 \\
\hline $\mathrm{C}$ & 4.21817200 & 1.15344300 & 0.01835800 \\
\hline $\mathrm{C}$ & 2.99011600 & 2.67408200 & 1.96038700 \\
\hline $\mathrm{C}$ & 4.86894800 & 2.27141200 & 0.52792500 \\
\hline $\mathrm{H}$ & 4.70934600 & 0.55941200 & -0.74764000 \\
\hline $\mathrm{C}$ & 4.25258900 & 3.03657000 & 1.51031300 \\
\hline $\mathrm{H}$ & 2.49368100 & 3.28498300 & 2.71222600 \\
\hline $\mathrm{H}$ & 5.85380000 & 2.54041100 & 0.15504500 \\
\hline $\mathrm{H}$ & 4.73899800 & 3.92068000 & 1.91331800 \\
\hline $\mathrm{Ni}$ & 0.05932400 & -0.05431800 & -0.59496900 \\
\hline $\mathrm{H}$ & -0.08899100 & 1.16317100 & -1.68736500 \\
\hline $\mathrm{C}$ & 3.16832400 & -1.14709500 & -1.67406300 \\
\hline $\mathrm{C}$ & 4.25974900 & -2.01006800 & -1.52217400 \\
\hline $\mathrm{C}$ & 2.90230300 & -0.60782300 & -2.93858900 \\
\hline $\mathrm{C}$ & 5.06045800 & -2.33330800 & -2.61405900 \\
\hline $\mathrm{H}$ & 4.47938900 & -2.43238600 & -0.54404600 \\
\hline $\mathrm{C}$ & 3.71317900 & -0.91783200 & -4.02577200 \\
\hline $\mathrm{H}$ & 2.03848100 & 0.04657900 & -3.05951000 \\
\hline $\mathrm{C}$ & 4.79100500 & -1.78586400 & -3.86617200 \\
\hline $\mathrm{H}$ & 5.90022500 & -3.01134100 & -2.48549200 \\
\hline $\mathrm{H}$ & 3.49600100 & -0.49155000 & -5.00154600 \\
\hline $\mathrm{H}$ & 5.41660400 & -2.03974600 & -4.71755800 \\
\hline $\mathrm{C}$ & 2.34910200 & -1.98593900 & 0.93157000 \\
\hline $\mathrm{C}$ & 2.80077700 & -1.75903600 & 2.23600400 \\
\hline $\mathrm{C}$ & 2.01450700 & -3.29480200 & 0.55750900 \\
\hline $\mathrm{C}$ & 2.89091200 & -2.80998600 & 3.14696000 \\
\hline $\mathrm{H}$ & 3.09953900 & -0.75881500 & 2.54155900 \\
\hline $\mathrm{C}$ & 2.11655500 & -4.34384900 & 1.46111100 \\
\hline $\mathrm{H}$ & 1.66992600 & -3.48379800 & -0.45686500 \\
\hline $\mathrm{C}$ & 2.54587100 & -4.10231400 & 2.76540600 \\
\hline $\mathrm{H}$ & 3.24111600 & -2.61547700 & 4.15750500 \\
\hline $\mathrm{H}$ & 1.84419900 & -5.34887400 & 1.14917900 \\
\hline $\mathrm{H}$ & 2.61574400 & -4.91951700 & 3.47804200 \\
\hline $\mathrm{C}$ & -1.48224500 & -2.99007200 & 0.19998100 \\
\hline $\mathrm{C}$ & -0.95805100 & -3.82427200 & -0.79952200 \\
\hline $\mathrm{C}$ & -1.76971700 & -3.55476900 & 1.44688700 \\
\hline $\mathrm{C}$ & -0.79166400 & -5.18738100 & -0.58459400 \\
\hline $\mathrm{H}$ & -0.65017200 & -3.38568900 & -1.74860400 \\
\hline $\mathrm{C}$ & -1.57783900 & -4.91621800 & 1.67198300 \\
\hline $\mathrm{H}$ & -2.13757600 & -2.92878200 & 2.25480500 \\
\hline $\mathrm{C}$ & -1.10772100 & -5.74080100 & 0.65457500 \\
\hline $\mathrm{H}$ & -0.39585800 & -5.81481900 & -1.37954900 \\
\hline $\mathrm{H}$ & -1.80128200 & -5.33334100 & 2.65061300 \\
\hline $\mathrm{H}$ & -0.96885500 & -6.80424300 & 0.83070100 \\
\hline $\mathrm{C}$ & -3.23022800 & -1.21458300 & -1.19175000 \\
\hline $\mathrm{C}$ & -4.20676200 & -0.22690000 & -1.01004800 \\
\hline
\end{tabular}

$\begin{array}{lrrr}\mathrm{C} & -3.42267500 & -2.15382900 & -2.21413300 \\ \mathrm{C} & -5.33731800 & -0.18474000 & -1.82177400 \\ \mathrm{H} & -4.08375800 & 0.52039600 & -0.23028400 \\ \mathrm{C} & -4.55403100 & -2.11380500 & -3.02020500 \\ \mathrm{H} & -2.68644800 & -2.93443800 & -2.37989100 \\ \mathrm{C} & -5.51838100 & -1.12688200 & -2.82906300 \\ \mathrm{H} & -6.07543100 & 0.59724500 & -1.65988900 \\ \mathrm{H} & -4.68227800 & -2.85877800 & -3.80107500 \\ \mathrm{H} & -6.40266100 & -1.09440500 & -3.45949600 \\ \mathrm{C} & -2.22294800 & 2.57680800 & -0.46603200 \\ \mathrm{C} & -2.80618700 & 2.61481200 & -1.74229700 \\ \mathrm{C} & -2.99898700 & 3.00853800 & 0.62181200 \\ \mathrm{C} & -4.11043300 & 3.06230300 & -1.92694600 \\ \mathrm{H} & -2.23875500 & 2.25905500 & -2.60159500 \\ \mathrm{C} & -4.31293900 & 3.43274700 & 0.44587700 \\ \mathrm{H} & -2.57998600 & 2.99232900 & 1.62628900 \\ \mathrm{C} & -4.87043500 & 3.46278800 & -0.83098800 \\ \mathrm{H} & -4.54364000 & 3.07319700 & -2.92391700 \\ \mathrm{H} & -4.90128800 & 3.74246000 & 1.30574600 \\ \mathrm{H} & -5.89623900 & 3.79501400 & -0.97027100 \\ \mathrm{C} & 0.67923600 & 3.47272800 & -0.32373300 \\ \mathrm{C} & 0.40553200 & 4.57201200 & 0.50422700 \\ \mathrm{C} & 1.81383500 & 3.52731000 & -1.14450100 \\ \mathrm{C} & 1.25078800 & 5.67671400 & 0.53406900 \\ \mathrm{H} & -0.48587800 & 4.56225700 & 1.13279000 \\ \mathrm{C} & 2.65971800 & 4.63122300 & -1.12331800 \\ \mathrm{H} & 2.04930100 & 2.67482200 & -1.78282000 \\ \mathrm{C} & 2.38103000 & 5.70524900 & -0.28054200 \\ \mathrm{H} & 1.02719900 & 6.51771300 & 1.18565700 \\ \mathrm{H} & 3.54296000 & 4.65052800 & -1.75669200 \\ \mathrm{H} & 3.04334800 & 6.56696300 & -0.26079700\end{array}$

\section{Compound: 2[I-4P1]}

Charge: 0

Multiplicity: 1

Lowest Frequency: $13.83 \mathrm{~cm}^{-1}$

Energy: -4426.775218 Hartree

$\begin{array}{lrrr}\mathrm{P} & 2.67933300 & -1.09462900 & -0.00141100 \\ \mathrm{P} & -4.43835400 & 0.19575100 & -0.71457700 \\ \mathrm{~N} & -0.10418900 & -0.80868100 & -0.04856400 \\ \mathrm{C} & 1.59722000 & -2.13721200 & 0.99282000 \\ \mathrm{C} & 2.01888600 & -3.15124600 & 1.84875500 \\ \mathrm{C} & 1.09591400 & -3.87749400 & 2.59350800 \\ \mathrm{C} & -0.25778500 & -3.55402200 & 2.46480000 \\ \mathrm{C} & -0.69642300 & -2.54769600 & 1.61849700 \\ \mathrm{C} & 0.22251700 & -1.81018700 & 0.82913100 \\ \mathrm{C} & -1.50801600 & -0.53094200 & -0.20993700 \\ \mathrm{C} & -2.09231500 & 0.45000000 & 0.78660700 \\ \mathrm{C} & -1.30651300 & 0.97379600 & 1.81406300 \\ \mathrm{C} & -1.81042700 & 1.92433300 & 2.69754300 \\ \mathrm{C} & -3.12285400 & 2.36320700 & 2.56722700 \\ \mathrm{C} & -3.92928100 & 1.83573200 & 1.56255800 \\ \mathrm{C} & -3.43473800 & 0.87933200 & 0.66773100 \\ \mathrm{C} & 3.94275300 & -0.48479400 & 1.15745100 \\ \mathrm{C} & 5.22973700 & -0.14706600 & 0.72262900 \\ \mathrm{C} & 6.13760200 & 0.43984300 & 1.59755700 \\ \mathrm{C} & 5.76805500 & 0.70505600 & 2.91405300\end{array}$




\begin{tabular}{|c|c|c|c|}
\hline $\mathrm{C}$ & 4.48739800 & 0.37873600 & 3.35242800 \\
\hline $\mathrm{C}$ & 3.57785500 & -0.21124400 & 2.48096700 \\
\hline $\mathrm{C}$ & 3.56635600 & -2.18111700 & -1.16587100 \\
\hline $\mathrm{C}$ & 3.14397400 & -2.21394100 & -2.49945900 \\
\hline $\mathrm{C}$ & 3.73456400 & -3.08857000 & -3.40523200 \\
\hline $\mathrm{C}$ & 4.76111200 & -3.93201100 & -2.98840000 \\
\hline $\mathrm{C}$ & 5.19479000 & -3.89972400 & -1.66458300 \\
\hline $\mathrm{C}$ & 4.60013800 & -3.03115400 & -0.75554200 \\
\hline $\mathrm{C}$ & -6.06504700 & 0.99902700 & -0.43797800 \\
\hline $\mathrm{C}$ & -6.25843700 & 2.26996100 & -0.99838600 \\
\hline $\mathrm{C}$ & -7.45911500 & 2.94970000 & -0.82642700 \\
\hline $\mathrm{C}$ & -8.49723200 & 2.35861200 & -0.10906300 \\
\hline $\mathrm{C}$ & -8.32253700 & 1.09143800 & 0.44059100 \\
\hline $\mathrm{C}$ & -7.11458800 & 0.41766900 & 0.28264900 \\
\hline $\mathrm{C}$ & -4.75530400 & -1.51581900 & -0.11685200 \\
\hline $\mathrm{C}$ & -5.24634300 & -2.45020900 & -1.03750600 \\
\hline $\mathrm{C}$ & -5.49951900 & -3.76368900 & -0.65408600 \\
\hline $\mathrm{C}$ & -5.24620800 & -4.16974400 & 0.65382900 \\
\hline $\mathrm{C}$ & -4.75119900 & -3.25285100 & 1.57738700 \\
\hline $\mathrm{C}$ & -4.51520900 & -1.93386200 & 1.19870200 \\
\hline $\mathrm{H}$ & 3.08424700 & -3.35914700 & 1.94489400 \\
\hline $\mathrm{H}$ & 1.42092500 & -4.66444700 & 3.26635300 \\
\hline $\mathrm{H}$ & -0.99686900 & -4.09615400 & 3.05184300 \\
\hline $\mathrm{H}$ & -1.75714600 & -2.31982300 & 1.57682400 \\
\hline $\mathrm{H}$ & -2.09264500 & -1.46474300 & -0.19540800 \\
\hline $\mathrm{H}$ & -0.27950300 & 0.62829300 & 1.91053400 \\
\hline $\mathrm{H}$ & -1.17523300 & 2.31991000 & 3.48614100 \\
\hline $\mathrm{H}$ & -3.52696000 & 3.10573600 & 3.24997600 \\
\hline $\mathrm{H}$ & -4.95931900 & 2.17168300 & 1.47451600 \\
\hline $\mathrm{H}$ & 5.52104200 & -0.34303500 & -0.30850200 \\
\hline $\mathrm{H}$ & 7.13358400 & 0.69758400 & 1.24779800 \\
\hline $\mathrm{H}$ & 6.47634700 & 1.16804800 & 3.59528700 \\
\hline $\mathrm{H}$ & 4.19290900 & 0.58693900 & 4.37747600 \\
\hline $\mathrm{H}$ & 2.57647700 & -0.46528800 & 2.82247900 \\
\hline $\mathrm{H}$ & 2.34309300 & -1.54436100 & -2.81544800 \\
\hline $\mathrm{H}$ & 3.39708900 & -3.10717700 & -4.43749800 \\
\hline $\mathrm{H}$ & 5.22673500 & -4.61271700 & -3.69553500 \\
\hline $\mathrm{H}$ & 5.99915600 & -4.55339700 & -1.33856100 \\
\hline $\mathrm{H}$ & 4.94643500 & -3.00338600 & 0.27555200 \\
\hline $\mathrm{H}$ & -5.45145800 & 2.72924500 & -1.56849600 \\
\hline $\mathrm{H}$ & -7.58902300 & 3.93708400 & -1.26110600 \\
\hline $\mathrm{H}$ & -9.44056300 & 2.88290200 & 0.01723100 \\
\hline $\mathrm{H}$ & -9.12892800 & 0.62535600 & 1.00067700 \\
\hline $\mathrm{H}$ & -6.98469500 & -0.56724300 & 0.72452200 \\
\hline $\mathrm{H}$ & -5.42594600 & -2.14182600 & -2.06579400 \\
\hline $\mathrm{H}$ & -5.88262200 & -4.47459100 & -1.38093000 \\
\hline $\mathrm{H}$ & -5.42916600 & -5.19873900 & 0.95070300 \\
\hline $\mathrm{H}$ & -4.54802500 & -3.56266900 & 2.59965600 \\
\hline $\mathrm{H}$ & -4.13284700 & -1.22295200 & 1.92847300 \\
\hline $\mathrm{Ni}$ & 1.28071800 & 0.24484900 & -0.80539600 \\
\hline $\mathrm{Si}$ & 2.98407500 & 1.41556000 & -1.51588900 \\
\hline $\mathrm{H}$ & -1.67699200 & -0.12919800 & -1.21806800 \\
\hline $\mathrm{H}$ & 3.93564100 & 0.99878000 & -2.57748900 \\
\hline $\mathrm{C}$ & 1.30754500 & 1.76177100 & -2.20128100 \\
\hline $\mathrm{C}$ & 0.30086100 & 2.11854600 & -1.24710500 \\
\hline $\mathrm{C}$ & 0.85773700 & 1.35812600 & -3.49387100 \\
\hline $\mathrm{C}$ & -1.04019800 & 2.28331800 & -1.65847400 \\
\hline $\mathrm{H}$ & 0.59182900 & 2.58452800 & -0.30285300 \\
\hline
\end{tabular}

$\begin{array}{lrrr}\mathrm{C} & -0.47006300 & 1.46053500 & -3.85221300 \\ \mathrm{H} & 1.59008700 & 1.00949300 & -4.21991100 \\ \mathrm{C} & -1.42603100 & 1.95010300 & -2.93916400 \\ \mathrm{H} & -1.77396000 & 2.65005300 & -0.94409100 \\ \mathrm{H} & -0.77934900 & 1.18090800 & -4.85614200 \\ \mathrm{H} & -2.46435900 & 2.05373800 & -3.24184800 \\ \mathrm{C} & 3.72521100 & 2.66833900 & -0.34955300 \\ \mathrm{C} & 3.15921000 & 2.86509300 & 0.92073200 \\ \mathrm{C} & 4.86034500 & 3.42012900 & -0.68955500 \\ \mathrm{C} & 3.68999000 & 3.79411900 & 1.80899300 \\ \mathrm{H} & 2.30375900 & 2.25821600 & 1.22396300 \\ \mathrm{C} & 5.39631100 & 4.34869700 & 0.19769100 \\ \mathrm{H} & 5.32944100 & 3.27801400 & -1.66177300 \\ \mathrm{C} & 4.80950800 & 4.53972500 & 1.44702200 \\ \mathrm{H} & 3.23959100 & 3.92488800 & 2.78956100 \\ \mathrm{H} & 6.27366200 & 4.92477600 & -0.08464600 \\ \mathrm{H} & 5.22977800 & 5.26295300 & 2.14066100\end{array}$

\section{Compound: 2[I-4P2] \\ Charge: 0 \\ Multiplicity: 1 \\ Lowest Frequency: $8.14 \mathrm{~cm}^{-1}$ \\ Energy: -4426.740753 Hartree}

$\begin{array}{llrl}\mathrm{P} & -2.61207100 & -1.23163300 & -0.50575700 \\ \mathrm{P} & 3.67853000 & -0.34126900 & 1.12299000 \\ \mathrm{~N} & -0.38151300 & 0.70340500 & 0.06852900 \\ \mathrm{C} & -1.88011900 & -0.91388400 & 1.15175500 \\ \mathrm{C} & -2.33225800 & -1.54906200 & 2.31418600 \\ \mathrm{C} & -1.69051000 & -1.35760900 & 3.53146000 \\ \mathrm{C} & -0.57200300 & -0.52729500 & 3.59074300 \\ \mathrm{C} & -0.12655900 & 0.13358300 & 2.45320000 \\ \mathrm{C} & -0.78765600 & -0.03093000 & 1.22996400 \\ \mathrm{C} & 1.06580700 & 0.68540800 & -0.19511700 \\ \mathrm{C} & 1.53656600 & -0.67151600 & -0.64828800 \\ \mathrm{C} & 0.81094600 & -1.32930700 & -1.64211500 \\ \mathrm{C} & 1.17830000 & -2.58674900 & -2.10016800 \\ \mathrm{C} & 2.30560700 & -3.20045200 & -1.56275200 \\ \mathrm{C} & 3.06555600 & -2.54405800 & -0.59965300 \\ \mathrm{C} & 2.70152500 & -1.27392400 & -0.13388100 \\ \mathrm{C} & -2.12901800 & -2.95906800 & -0.88344200 \\ \mathrm{C} & -2.47339200 & -3.44919000 & -2.15282700 \\ \mathrm{C} & -2.06429200 & -4.71193600 & -2.56565200 \\ \mathrm{C} & -1.27486500 & -5.49735000 & -1.72624300 \\ \mathrm{C} & -0.90393600 & -5.00993300 & -0.47678200 \\ \mathrm{C} & -1.32834700 & -3.75196500 & -0.05437500 \\ \mathrm{C} & -4.39555100 & -1.32211500 & -0.10881900 \\ \mathrm{C} & -4.94227400 & -0.30502300 & 0.68774200 \\ \mathrm{C} & -6.30520100 & -0.26979500 & 0.95448700 \\ \mathrm{C} & -7.14897200 & -1.24807600 & 0.43184500 \\ \mathrm{C} & -6.61424100 & -2.26507600 & -0.35366500 \\ \mathrm{C} & -5.24871000 & -2.30431000 & -0.62203400 \\ \mathrm{C} & 4.21531700 & 1.07911500 & 0.08165200 \\ \mathrm{C} & 4.33211100 & 2.33693100 & 0.68537900 \\ \mathrm{C} & 4.66096000 & 3.46047600 & -0.06733000 \\ \mathrm{C} & 4.87033800 & 3.34318200 & -1.43811100 \\ \mathrm{C} & 4.75043100 & 2.09914400 & -2.05423300 \\ \mathrm{C} & 4.42488600 & 0.97576600 & -1.30067400\end{array}$




\begin{tabular}{|c|c|c|c|c|c|c|c|}
\hline $\mathrm{C}$ & 5.19382800 & -1.36516000 & 1.26257400 & $\mathrm{H}$ & 1.51120900 & 5.97083400 & 0.75217300 \\
\hline $\mathrm{C}$ & 6.38416900 & -1.11505700 & 0.57118800 & $\mathrm{H}$ & 1.88918900 & 4.79094800 & -3.36206700 \\
\hline $\mathrm{C}$ & 7.49543900 & -1.93362800 & 0.75683300 & $\mathrm{H}$ & 2.56021700 & 6.25850300 & -1.47780300 \\
\hline $\mathrm{C}$ & 7.43275500 & -3.01881300 & 1.62586900 & & & & \\
\hline $\mathrm{C}$ & 6.25359200 & -3.27844700 & 2.32093900 & \multicolumn{4}{|c|}{ Compound: $2[\mathrm{I}-\mathrm{DA}]$} \\
\hline $\mathrm{C}$ & 5.14915500 & -2.45144400 & 2.14931700 & \multicolumn{4}{|c|}{ Charge: 0} \\
\hline $\mathrm{H}$ & -3.19498800 & -2.20983500 & 2.24973400 & \multicolumn{4}{|c|}{ Multiplicity: 1} \\
\hline $\mathrm{H}$ & -2.04844200 & -1.86172900 & 4.42453100 & \multicolumn{4}{|c|}{ Lowest Frequency: $18.57 \mathrm{~cm}^{-1}$} \\
\hline $\mathrm{H}$ & -0.05033700 & -0.37982100 & 4.53263500 & \multicolumn{4}{|c|}{ Energy: -5463.050694 Hartree } \\
\hline $\mathrm{H}$ & 0.73397300 & 0.79581400 & 2.51707500 & & & & \\
\hline $\mathrm{H}$ & 1.62507000 & 1.02793300 & 0.68524600 & $\mathrm{Ni}$ & -0.85326400 & 0.01674900 & -0.18566800 \\
\hline $\mathrm{H}$ & -0.09593000 & -0.84754700 & -2.03391100 & $\mathrm{P}$ & 0.21015400 & -1.83496200 & -0.40927500 \\
\hline $\mathrm{H}$ & 0.57696600 & -3.09012400 & -2.85274300 & $\mathrm{P}$ & -0.22871100 & 1.92268800 & -0.90956900 \\
\hline $\mathrm{H}$ & 2.60067000 & -4.19057300 & -1.90093700 & $\mathrm{P}$ & -2.83247800 & -0.14714600 & 0.60623000 \\
\hline $\mathrm{H}$ & 3.95950900 & -3.02355300 & -0.20931600 & $\mathrm{~N}$ & 1.83190200 & -0.10449200 & 1.61824400 \\
\hline $\mathrm{H}$ & -3.05720400 & -2.81971900 & -2.82355000 & $\mathrm{C}$ & 0.95122600 & -2.38944300 & 1.19314800 \\
\hline $\mathrm{H}$ & -2.35026500 & -5.07847800 & -3.54817800 & $\mathrm{C}$ & 0.81625100 & -3.70191200 & 1.66842300 \\
\hline $\mathrm{H}$ & -0.94151500 & -6.47919400 & -2.05121700 & $\mathrm{C}$ & 1.16277200 & -4.04428800 & 2.97153000 \\
\hline $\mathrm{H}$ & -0.27318600 & -5.60873900 & 0.17516600 & $\mathrm{C}$ & 1.63826100 & -3.06770100 & 3.84300700 \\
\hline $\mathrm{H}$ & -1.01343500 & -3.37512800 & 0.91578700 & $\mathrm{C}$ & 1.82315400 & -1.77066900 & 3.37739000 \\
\hline $\mathrm{H}$ & -4.28911600 & 0.45694900 & 1.10933900 & $\mathrm{C}$ & 1.53091600 & -1.42914000 & 2.05274300 \\
\hline $\mathrm{H}$ & -6.70600400 & 0.52679300 & 1.57702800 & $\mathrm{C}$ & 0.78008800 & 0.87279200 & 1.95221900 \\
\hline $\mathrm{H}$ & -8.21490600 & -1.22072700 & 0.64065300 & $\mathrm{C}$ & 1.12859400 & 2.28139000 & 1.55945400 \\
\hline $\mathrm{H}$ & -7.26184200 & -3.03919500 & -0.75733000 & $\mathrm{C}$ & 1.80582000 & 3.06524300 & 2.50033700 \\
\hline $\mathrm{H}$ & -4.84642500 & -3.11319000 & -1.22680900 & $\mathrm{C}$ & 2.28122400 & 4.33034300 & 2.18877400 \\
\hline $\mathrm{H}$ & 4.14414900 & 2.43405400 & 1.75322900 & $\mathrm{C}$ & 2.10204900 & 4.82712600 & 0.90143900 \\
\hline $\mathrm{H}$ & 4.73650300 & 4.43212200 & 0.41399200 & $\mathrm{C}$ & 1.39720200 & 4.07845000 & -0.03310000 \\
\hline $\mathrm{H}$ & 5.11111500 & 4.22261800 & -2.02968800 & $\mathrm{C}$ & 0.86576000 & 2.81614200 & 0.27859100 \\
\hline $\mathrm{H}$ & 4.90497200 & 2.00447000 & -3.12585900 & $\mathrm{C}$ & 1.55926700 & -2.14681900 & -1.62099600 \\
\hline $\mathrm{H}$ & 4.31615400 & 0.00739500 & -1.78606800 & $\mathrm{C}$ & 1.72051300 & -1.25305300 & -2.67864400 \\
\hline $\mathrm{H}$ & 6.44471500 & -0.27422800 & -0.11495200 & $\mathrm{C}$ & 2.62274900 & -1.52421400 & -3.70641900 \\
\hline $\mathrm{H}$ & 8.41343400 & -1.72321800 & 0.21434900 & $\mathrm{C}$ & 3.36469100 & -2.70025800 & -3.68408700 \\
\hline $\mathrm{H}$ & 8.30071600 & -3.65715900 & 1.76603400 & $\mathrm{C}$ & 3.21433100 & -3.59948700 & -2.62742100 \\
\hline $\mathrm{H}$ & 6.19726100 & -4.12058200 & 3.00537200 & $\mathrm{C}$ & 2.32059200 & -3.32319300 & -1.60071800 \\
\hline $\mathrm{H}$ & 4.23391100 & -2.64893700 & 2.70521800 & $\mathrm{C}$ & -0.88672200 & -3.24329900 & -0.86919000 \\
\hline $\mathrm{Ni}$ & -1.66043600 & 0.31287000 & -1.54601900 & $\mathrm{C}$ & -1.85944900 & -3.69693700 & 0.03373900 \\
\hline $\mathrm{Si}$ & -1.35145200 & 2.11554100 & -0.61725300 & $\mathrm{C}$ & -2.75186900 & -4.70124600 & -0.31865300 \\
\hline $\mathrm{H}$ & 1.27745400 & 1.43026200 & -0.97344500 & $\mathrm{C}$ & -2.71526100 & -5.25330900 & -1.59802400 \\
\hline $\mathrm{H}$ & -2.08075400 & 1.72653900 & -2.14744200 & $\mathrm{C}$ & -1.77985600 & -4.78792900 & -2.51617600 \\
\hline $\mathrm{C}$ & -2.72469900 & 2.64119900 & 0.53083900 & $\mathrm{C}$ & -0.87035800 & -3.79655100 & -2.15550800 \\
\hline $\mathrm{C}$ & -3.97158000 & 2.98141500 & -0.02057300 & $\mathrm{C}$ & 0.65407700 & 2.08989400 & -2.52394500 \\
\hline $\mathrm{C}$ & -2.60174500 & 2.64223900 & 1.93020300 & $\mathrm{C}$ & 2.00797400 & 2.41521000 & -2.66222700 \\
\hline $\mathrm{C}$ & -5.05094700 & 3.31387400 & 0.79094500 & $\mathrm{C}$ & 2.63017300 & 2.38191300 & -3.90852500 \\
\hline $\mathrm{H}$ & -4.10507000 & 2.95690100 & -1.10092600 & $\mathrm{C}$ & 1.90923800 & 2.03296900 & -5.04551100 \\
\hline $\mathrm{C}$ & -3.68622900 & 2.95573100 & 2.74543700 & $\mathrm{C}$ & 0.55731900 & 1.71232300 & -4.92495600 \\
\hline $\mathrm{H}$ & -1.65371300 & 2.37458000 & 2.39323500 & $\mathrm{C}$ & -0.05838800 & 1.73684600 & -3.68018600 \\
\hline $\mathrm{C}$ & -4.91225400 & 3.29398500 & 2.17728700 & $\mathrm{C}$ & -1.59400100 & 3.13112100 & -1.25450500 \\
\hline $\mathrm{H}$ & -6.00791800 & 3.56802300 & 0.34231100 & $\mathrm{C}$ & -2.72058600 & 2.60176000 & -1.89912200 \\
\hline $\mathrm{H}$ & -3.57343500 & 2.93412900 & 3.82623800 & $\mathrm{C}$ & -3.79266800 & 3.40786400 & -2.26106300 \\
\hline $\mathrm{H}$ & -5.75912900 & 3.53751200 & 2.81360400 & $\mathrm{C}$ & -3.77326100 & 4.76778500 & -1.96480000 \\
\hline $\mathrm{C}$ & -0.13963400 & 3.50242700 & -0.93567400 & $\mathrm{C}$ & -2.67895200 & 5.30347700 & -1.29452400 \\
\hline $\mathrm{C}$ & 0.25056800 & 4.34645500 & 0.11533100 & $\mathrm{C}$ & -1.59975400 & 4.49501100 & -0.94451700 \\
\hline $\mathrm{C}$ & 0.46392600 & 3.68288900 & -2.18886800 & $\mathrm{C}$ & -3.94204100 & -1.21522000 & -0.39299700 \\
\hline $\mathrm{C}$ & 1.21683200 & 5.32930500 & -0.07463400 & $\mathrm{C}$ & -5.07275400 & -1.86949100 & 0.10619400 \\
\hline $\mathrm{H}$ & -0.21305700 & 4.23259300 & 1.09527700 & $\mathrm{C}$ & -5.86751000 & -2.64567800 & -0.73315800 \\
\hline $\mathrm{C}$ & 1.42741400 & 4.66813900 & -2.38565200 & $\mathrm{C}$ & -5.54554200 & -2.77401000 & -2.08199200 \\
\hline $\mathrm{H}$ & 0.17608500 & 3.03233200 & -3.01449800 & $\mathrm{C}$ & -4.41733900 & -2.13342700 & -2.58872900 \\
\hline $\mathrm{C}$ & 1.80390200 & 5.49193000 & -1.32754500 & $\mathrm{C}$ & -3.61808100 & -1.36782300 & -1.74704700 \\
\hline
\end{tabular}




\begin{tabular}{|c|c|c|c|c|c|c|c|}
\hline $\mathrm{C}$ & -3.02992200 & -0.75808800 & 2.34247700 & $\mathrm{C}$ & 4.26149000 & 1.58458200 & 1.21096200 \\
\hline $\mathrm{C}$ & -1.97201600 & -1.44478800 & 2.94570100 & $\mathrm{C}$ & 4.68893500 & 1.55988600 & 2.54691500 \\
\hline $\mathrm{C}$ & -2.06449900 & -1.90843100 & 4.25591200 & $\mathrm{C}$ & 4.74530400 & 2.60831700 & 0.38773000 \\
\hline $\mathrm{C}$ & -3.22476400 & -1.68551600 & 4.99020600 & $\mathrm{C}$ & 5.55068300 & 2.52856300 & 3.04738600 \\
\hline $\mathrm{C}$ & -4.28428900 & -0.99066600 & 4.40966100 & $\mathrm{H}$ & 4.32643800 & 0.77067700 & 3.20711200 \\
\hline $\mathrm{C}$ & -4.18503300 & -0.52428300 & 3.10294700 & $\mathrm{C}$ & 5.61241500 & 3.58235500 & 0.87932700 \\
\hline $\mathrm{C}$ & -3.86678500 & 1.36751500 & 0.79629900 & $\mathrm{H}$ & 4.44104600 & 2.64233500 & -0.65907200 \\
\hline $\mathrm{C}$ & -3.30208100 & 2.42128800 & 1.52647900 & $\mathrm{C}$ & 6.01199000 & 3.54609700 & 2.21186200 \\
\hline $\mathrm{C}$ & -4.01237200 & 3.59093600 & 1.75759500 & $\mathrm{H}$ & 5.86809000 & 2.49309600 & 4.08659800 \\
\hline $\mathrm{C}$ & -5.30509400 & 3.73284300 & 1.25380000 & $\mathrm{H}$ & 5.97164400 & 4.37228500 & 0.22405700 \\
\hline $\mathrm{C}$ & -5.87282300 & 2.69862700 & 0.51796200 & $\mathrm{H}$ & 6.68700900 & 4.30489000 & 2.59929300 \\
\hline $\mathrm{C}$ & -5.15952900 & 1.52276200 & 0.28999000 & $\mathrm{C}$ & 4.25347200 & -1.26997700 & 0.26145900 \\
\hline $\mathrm{H}$ & 0.40554000 & -4.46451300 & 1.01221000 & $\mathrm{C}$ & 4.50262400 & -2.29588000 & 1.18422700 \\
\hline $\mathrm{H}$ & 1.04673100 & -5.07088700 & 3.30812200 & $\mathrm{C}$ & 4.99643100 & -1.27014800 & -0.93020900 \\
\hline $\mathrm{H}$ & 1.88849300 & -3.31881500 & 4.87021600 & $\mathrm{C}$ & 5.43266700 & -3.29562300 & 0.91530200 \\
\hline $\mathrm{H}$ & 2.23788400 & -0.99926300 & 4.02381200 & $\mathrm{H}$ & 3.96094100 & -2.32633300 & 2.12570600 \\
\hline $\mathrm{H}$ & -0.18361100 & 0.57648200 & 1.47023600 & $\mathrm{C}$ & 5.94197400 & -2.25612800 & -1.19478100 \\
\hline $\mathrm{H}$ & 1.99460200 & 2.64218700 & 3.48509300 & $\mathrm{H}$ & 4.81335000 & -0.49587300 & -1.67679700 \\
\hline $\mathrm{H}$ & 2.82067900 & 4.90851500 & 2.93368500 & $\mathrm{C}$ & 6.15601000 & -3.27811100 & -0.27422100 \\
\hline $\mathrm{H}$ & 2.50099800 & 5.79985800 & 0.62607000 & $\mathrm{H}$ & 5.59693500 & -4.08745700 & 1.64176500 \\
\hline $\mathrm{H}$ & 1.24724400 & 4.48021300 & -1.03223700 & $\mathrm{H}$ & 6.49656600 & -2.23728900 & -2.12996300 \\
\hline $\mathrm{H}$ & 1.13387600 & -0.33849300 & -2.68525700 & $\mathrm{H}$ & 6.88581900 & -4.05669600 & -0.48159900 \\
\hline $\mathrm{H}$ & 2.73562800 & -0.81376700 & -4.52147600 & $\mathrm{H}$ & 0.58814400 & 0.82613200 & 3.03644500 \\
\hline $\mathrm{H}$ & 4.06823600 & -2.91692000 & -4.48439100 & & & & \\
\hline $\mathrm{H}$ & 3.80779300 & -4.50965500 & -2.59754800 & \multicolumn{4}{|c|}{ Compound: $2[\mathrm{I}-\mathrm{DA}]^{-}$} \\
\hline $\mathrm{H}$ & 2.21033400 & -4.02479400 & -0.77499000 & \multicolumn{4}{|c|}{ Charge: -1} \\
\hline $\mathrm{H}$ & -1.91718100 & -3.25107200 & 1.02646900 & \multicolumn{4}{|c|}{ Multiplicity: 1} \\
\hline $\mathrm{H}$ & -3.49066200 & -5.03994400 & 0.40321400 & \multicolumn{4}{|c|}{ Lowest Frequency: $14.68 \mathrm{~cm}^{-1}$} \\
\hline $\mathrm{H}$ & -3.42066400 & -6.03116200 & -1.87848000 & \multirow{2}{*}{\multicolumn{4}{|c|}{ Energy: -4709.740839 Hartree }} \\
\hline $\mathrm{H}$ & -1.74974700 & -5.20096300 & -3.52140900 & & & & \\
\hline $\mathrm{H}$ & -0.14088800 & -3.45445200 & -2.88464200 & $\mathrm{Ni}$ & -0.07384900 & 0.04205000 & 0.20417800 \\
\hline $\mathrm{H}$ & 2.58734000 & 2.68961600 & -1.78690300 & $\mathrm{P}$ & 1.01146300 & 1.84888100 & -0.06790800 \\
\hline $\mathrm{H}$ & 3.68567500 & 2.63253200 & -3.98518300 & $\mathrm{P}$ & -2.15810400 & -0.07346300 & -0.12755500 \\
\hline $\mathrm{H}$ & 2.39424900 & 2.00800600 & -6.01772100 & $\mathrm{P}$ & 1.14295200 & -1.62495400 & -0.09799300 \\
\hline $\mathrm{H}$ & -0.01860400 & 1.43535700 & -5.80383200 & $\mathrm{~N}$ & -0.56534600 & 0.71506800 & 2.07758200 \\
\hline $\mathrm{H}$ & -1.10742000 & 1.46015300 & -3.59794800 & $\mathrm{C}$ & 0.74854400 & 2.65330900 & 1.53669200 \\
\hline $\mathrm{H}$ & -2.77527400 & 1.52568300 & -2.07373500 & $\mathrm{C}$ & 1.33924700 & 3.85828100 & 1.91429000 \\
\hline $\mathrm{H}$ & -4.65719700 & 2.96422500 & -2.74858200 & $\mathrm{C}$ & 1.09731300 & 4.43638300 & 3.15827300 \\
\hline $\mathrm{H}$ & -4.61700100 & 5.39844500 & -2.23180000 & $\mathrm{C}$ & 0.24000200 & 3.76629900 & 4.03772300 \\
\hline $\mathrm{H}$ & -2.66315400 & 6.35830900 & -1.03216300 & $\mathrm{C}$ & -0.34436900 & 2.55585300 & 3.70498300 \\
\hline $\mathrm{H}$ & -0.77219000 & 4.93939200 & -0.40214100 & $\mathrm{C}$ & -0.09651300 & 1.92898400 & 2.44640300 \\
\hline $\mathrm{H}$ & -5.32992100 & -1.77841400 & 1.15928200 & $\mathrm{C}$ & -1.46888500 & 0.09003300 & 3.00041600 \\
\hline $\mathrm{H}$ & -6.74059000 & -3.15363000 & -0.33095100 & $\mathrm{C}$ & -2.19846100 & -1.12904200 & 2.49299700 \\
\hline $\mathrm{H}$ & -6.16486700 & -3.38428600 & -2.73385300 & $\mathrm{C}$ & -2.45055300 & -2.15519000 & 3.40549200 \\
\hline $\mathrm{H}$ & -4.14526900 & -2.24912400 & -3.63466400 & $\mathrm{C}$ & -3.21246600 & -3.27362600 & 3.07254100 \\
\hline $\mathrm{H}$ & -2.70120000 & -0.90506600 & -2.12027600 & $\mathrm{C}$ & -3.74900900 & -3.37080000 & 1.79449500 \\
\hline $\mathrm{H}$ & -1.06261800 & -1.61064500 & 2.37441800 & $\mathrm{C}$ & -3.49754500 & -2.36701400 & 0.86286800 \\
\hline $\mathrm{H}$ & -1.22251100 & -2.43681800 & 4.69631600 & $\mathrm{C}$ & -2.72152300 & -1.24279000 & 1.17919600 \\
\hline $\mathrm{H}$ & -3.30163500 & -2.04144900 & 6.01421900 & $\mathrm{C}$ & 0.57578900 & 3.08633100 & -1.35213300 \\
\hline $\mathrm{H}$ & -5.18943600 & -0.80128100 & 4.98108900 & $\mathrm{C}$ & 0.66243600 & 2.68445100 & -2.69631400 \\
\hline $\mathrm{H}$ & -5.00789300 & 0.04270900 & 2.67250000 & $\mathrm{C}$ & 0.22870200 & 3.51163900 & -3.72478800 \\
\hline $\mathrm{H}$ & -2.28156800 & 2.32178400 & 1.90280000 & $\mathrm{C}$ & -0.33107900 & 4.75690000 & -3.43350200 \\
\hline $\mathrm{H}$ & -3.55246800 & 4.40053000 & 2.31850700 & $\mathrm{C}$ & -0.43839400 & 5.16147900 & -2.10567800 \\
\hline $\mathrm{H}$ & -5.85958200 & 4.65175500 & 1.42509900 & $\mathrm{C}$ & 0.01363100 & 4.33933100 & -1.07485700 \\
\hline $\mathrm{H}$ & -6.87616200 & 2.80546900 & 0.11264500 & $\mathrm{C}$ & 2.84895700 & 1.80563400 & -0.17525800 \\
\hline $\mathrm{H}$ & -5.61585800 & 0.72311700 & -0.28866400 & $\mathrm{C}$ & 3.51230900 & 1.24257200 & 0.92718000 \\
\hline $\mathrm{Si}$ & 3.15904400 & 0.23036600 & 0.52068300 & $\mathrm{C}$ & 4.89249700 & 1.09424400 & 0.93977300 \\
\hline $\mathrm{H}$ & 2.72304600 & 0.68177600 & -0.82147900 & $\mathrm{C}$ & 5.65074000 & 1.50804000 & -0.15599500 \\
\hline
\end{tabular}




\begin{tabular}{|c|c|c|c|c|c|c|c|}
\hline $\mathrm{C}$ & 5.00664400 & 2.06654000 & -1.25592700 & $\mathrm{H}$ & -4.67707100 & -2.14745100 & -4.84010500 \\
\hline $\mathrm{C}$ & 3.62047400 & 2.21443000 & -1.26757600 & $\mathrm{H}$ & -5.85215200 & -0.40534300 & -3.51824900 \\
\hline $\mathrm{C}$ & -3.09711300 & 1.45779900 & 0.24768200 & $\mathrm{H}$ & -4.82233300 & 0.50138400 & -1.45805800 \\
\hline $\mathrm{C}$ & -3.97852200 & 1.58957800 & 1.32573200 & $\mathrm{H}$ & 4.19560000 & -1.82401500 & -0.23279200 \\
\hline $\mathrm{C}$ & -4.57022400 & 2.81853500 & 1.61372600 & $\mathrm{H}$ & 5.77676800 & -1.27957700 & -2.04098400 \\
\hline $\mathrm{C}$ & -4.30760400 & 3.92776900 & 0.81564900 & $\mathrm{H}$ & 4.94386500 & -0.53586000 & -4.26023700 \\
\hline $\mathrm{C}$ & -3.44647600 & 3.80322200 & -0.27452000 & $\mathrm{H}$ & 2.49102000 & -0.30070800 & -4.63283600 \\
\hline $\mathrm{C}$ & -2.84248800 & 2.58224600 & -0.54952900 & $\mathrm{H}$ & 0.90719300 & -0.78404100 & -2.78732400 \\
\hline $\mathrm{C}$ & -3.03422200 & -0.69074100 & -1.62144600 & $\mathrm{H}$ & 1.41815800 & -0.68756700 & 2.58500200 \\
\hline $\mathrm{C}$ & -2.37622300 & -1.66313200 & -2.38621400 & $\mathrm{H}$ & 2.65482900 & -1.47964400 & 4.60480500 \\
\hline $\mathrm{C}$ & -2.96649600 & -2.19761700 & -3.52544200 & $\mathrm{H}$ & 4.01519400 & -3.55743100 & 4.48784900 \\
\hline $\mathrm{C}$ & -4.21821000 & -1.74354600 & -3.94054000 & $\mathrm{H}$ & 4.13385400 & -4.83672400 & 2.36288300 \\
\hline $\mathrm{C}$ & -4.87621500 & -0.76508100 & -3.19902400 & $\mathrm{H}$ & 2.90830900 & -4.03371400 & 0.36141200 \\
\hline $\mathrm{C}$ & -4.29489900 & -0.25017900 & -2.04195700 & $\mathrm{H}$ & -0.74146800 & -3.35181200 & 1.16518500 \\
\hline $\mathrm{C}$ & 2.43413700 & -1.37542600 & -1.39058800 & $\mathrm{H}$ & -1.98798400 & -5.36683300 & 0.49418000 \\
\hline $\mathrm{C}$ & 3.81241000 & -1.50580100 & -1.19895100 & $\mathrm{H}$ & -1.60130200 & -6.39618700 & -1.74552700 \\
\hline $\mathrm{C}$ & 4.70721400 & -1.20136800 & -2.22445700 & $\mathrm{H}$ & 0.09429100 & -5.40207500 & -3.26831400 \\
\hline $\mathrm{C}$ & 4.24265600 & -0.77795600 & -3.46495900 & $\mathrm{H}$ & 1.36434700 & -3.40465400 & -2.58333700 \\
\hline $\mathrm{C}$ & 2.86961100 & -0.64231300 & -3.67152200 & $\mathrm{H}$ & -0.96635000 & -0.19645200 & 3.94877800 \\
\hline $\mathrm{C}$ & 1.97986600 & -0.92410600 & -2.64132400 & & & & \\
\hline $\mathrm{C}$ & 2.11253500 & -2.28636600 & 1.33827100 & \multicolumn{4}{|c|}{ Compound: 2[TS1] } \\
\hline $\mathrm{C}$ & 2.03973000 & -1.58446700 & 2.54574400 & \multicolumn{4}{|c|}{ Charge: 0} \\
\hline $\mathrm{C}$ & 2.72314400 & -2.03658600 & 3.67310100 & \multicolumn{4}{|c|}{ Multiplicity: 1} \\
\hline $\mathrm{C}$ & 3.48281300 & -3.20184000 & 3.60837300 & \multicolumn{4}{|c|}{ Lowest Frequency: $-792.17 \mathrm{~cm}^{-1}$} \\
\hline $\mathrm{C}$ & 3.55006800 & -3.91995700 & 2.41464000 & \multicolumn{4}{|c|}{ Energy: -4426.762619 Hartree } \\
\hline $\mathrm{C}$ & 2.86537700 & -3.46677100 & 1.29092600 & & & & \\
\hline $\mathrm{C}$ & 0.40239000 & -3.22502200 & -0.65945600 & $\mathrm{P}$ & -1.26614400 & 1.22427900 & 0.50327000 \\
\hline $\mathrm{C}$ & -0.54510000 & -3.81088700 & 0.19570200 & $\mathrm{P}$ & 2.19938000 & -0.30044700 & -0.37112300 \\
\hline $\mathrm{C}$ & -1.25271700 & -4.94349600 & -0.18654800 & $\mathrm{~N}$ & 0.66276300 & 1.84836800 & -1.50883100 \\
\hline $\mathrm{C}$ & -1.03611000 & -5.51931700 & -1.43890700 & $\mathrm{C}$ & -1.25122200 & 2.81636500 & -0.38645100 \\
\hline $\mathrm{C}$ & -0.09067600 & -4.95774400 & -2.29206300 & $\mathrm{C}$ & -2.16030400 & 3.86422900 & -0.21978500 \\
\hline $\mathrm{C}$ & 0.62759800 & -3.82705000 & -1.90464100 & $\mathrm{C}$ & -2.13261000 & 4.95961600 & -1.07699400 \\
\hline $\mathrm{H}$ & 2.00614700 & 4.35271100 & 1.20653300 & $\mathrm{C}$ & -1.19813800 & 4.99885400 & -2.11372700 \\
\hline $\mathrm{H}$ & 1.56375500 & 5.37703800 & 3.43791100 & $\mathrm{C}$ & -0.28429600 & 3.96634400 & -2.28919100 \\
\hline $\mathrm{H}$ & 0.03251900 & 4.19605300 & 5.01766900 & $\mathrm{C}$ & -0.30007800 & 2.86388500 & -1.42493200 \\
\hline $\mathrm{H}$ & -0.98063600 & 2.06205200 & 4.43350500 & $\mathrm{C}$ & 0.63599700 & 0.96902500 & -2.58150100 \\
\hline $\mathrm{H}$ & -2.25835200 & 0.80465000 & 3.32098700 & $\mathrm{C}$ & 1.97215600 & 0.46371700 & -3.01964200 \\
\hline $\mathrm{H}$ & -2.02761800 & -2.06592100 & 4.40551000 & $\mathrm{C}$ & 2.37554900 & 0.59554700 & -4.34769300 \\
\hline $\mathrm{H}$ & -3.37986400 & -4.05831100 & 3.80653300 & $\mathrm{C}$ & 3.63262900 & 0.15491300 & -4.75147400 \\
\hline $\mathrm{H}$ & -4.35038200 & -4.23197200 & 1.51053200 & $\mathrm{C}$ & 4.49878800 & -0.42161900 & -3.82630100 \\
\hline $\mathrm{H}$ & -3.89981100 & -2.46945200 & -0.14182000 & $\mathrm{C}$ & 4.10234200 & -0.55854100 & -2.49844400 \\
\hline $\mathrm{H}$ & 1.06059100 & 1.69503700 & -2.92285000 & $\mathrm{C}$ & 2.83954200 & -0.13158300 & -2.08551700 \\
\hline $\mathrm{H}$ & 0.30940900 & 3.17767900 & -4.75696100 & $\mathrm{C}$ & -0.62636200 & 1.51534300 & 2.19170300 \\
\hline $\mathrm{H}$ & -0.68900200 & 5.39874700 & -4.23489000 & $\mathrm{C}$ & -0.07215100 & 0.42399000 & 2.87367100 \\
\hline $\mathrm{H}$ & -0.88174900 & 6.12626400 & -1.86555700 & $\mathrm{C}$ & 0.46205300 & 0.58868900 & 4.14707700 \\
\hline $\mathrm{H}$ & -0.09422800 & 4.65647500 & -0.04060100 & $\mathrm{C}$ & 0.46712700 & 1.84752400 & 4.74486300 \\
\hline $\mathrm{H}$ & 2.92232900 & 0.92508000 & 1.78551900 & $\mathrm{C}$ & -0.07486800 & 2.93899800 & 4.06960900 \\
\hline $\mathrm{H}$ & 5.37614000 & 0.64955800 & 1.80735800 & $\mathrm{C}$ & -0.62518700 & 2.77435500 & 2.80065500 \\
\hline $\mathrm{H}$ & 6.73204100 & 1.38996700 & -0.15384600 & $\mathrm{C}$ & -3.04850500 & 0.93494900 & 0.77476100 \\
\hline $\mathrm{H}$ & 5.58496500 & 2.38470100 & -2.12149400 & $\mathrm{C}$ & -3.84330000 & 0.72107300 & -0.35873300 \\
\hline $\mathrm{H}$ & 3.13936400 & 2.65716600 & -2.13648900 & $\mathrm{C}$ & -5.19124300 & 0.41064000 & -0.22807100 \\
\hline $\mathrm{H}$ & -4.19858900 & 0.72305000 & 1.94621600 & $\mathrm{C}$ & -5.76304600 & 0.31126600 & 1.03997800 \\
\hline $\mathrm{H}$ & -5.23951000 & 2.90729700 & 2.46670200 & $\mathrm{C}$ & -4.98360400 & 0.53653000 & 2.17148900 \\
\hline $\mathrm{H}$ & -4.76461900 & 4.88733000 & 1.04534800 & $\mathrm{C}$ & -3.63163500 & 0.84731600 & 2.04258100 \\
\hline $\mathrm{H}$ & -3.22641200 & 4.66252300 & -0.90398400 & $\mathrm{C}$ & 3.18783900 & 0.91986000 & 0.58013300 \\
\hline $\mathrm{H}$ & -2.14708200 & 2.49510700 & -1.38358100 & $\mathrm{C}$ & 2.57791300 & 2.08107300 & 1.06167900 \\
\hline $\mathrm{H}$ & -1.38974900 & -1.99814300 & -2.06877200 & $\mathrm{C}$ & 3.30990000 & 3.01488600 & 1.78931800 \\
\hline $\mathrm{H}$ & -2.44234400 & -2.96373900 & -4.09253800 & $\mathrm{C}$ & 4.66289000 & 2.80341100 & 2.03713800 \\
\hline
\end{tabular}




\begin{tabular}{|c|c|c|c|c|c|c|c|}
\hline $\mathrm{C}$ & 5.28372800 & 1.65271400 & 1.55492200 & $\mathrm{H}$ & -3.28544900 & -3.59047100 & -0.51158900 \\
\hline $\mathrm{C}$ & 4.55121300 & 0.71700500 & 0.83255700 & $\mathrm{C}$ & -4.90098700 & -2.32942500 & -3.21564300 \\
\hline $\mathrm{C}$ & 2.87270700 & -1.89303700 & 0.19845500 & $\mathrm{H}$ & -4.10592000 & -0.82592600 & -4.53855300 \\
\hline $\mathrm{C}$ & 3.16611800 & -2.08600400 & 1.55648600 & $\mathrm{H}$ & -5.41094300 & -3.80721000 & -1.73497500 \\
\hline $\mathrm{C}$ & 3.52145300 & -3.34355900 & 2.03204600 & $\mathrm{H}$ & -5.84083500 & -2.42367600 & -3.75364300 \\
\hline $\mathrm{C}$ & 3.57601600 & -4.43236000 & 1.16408300 & & & & \\
\hline $\mathrm{C}$ & 3.27649000 & -4.25402000 & -0.18500100 & \multicolumn{4}{|c|}{ Compound: 2[TS2a] } \\
\hline $\mathrm{C}$ & 2.92500200 & -2.99597200 & -0.66502200 & \multicolumn{4}{|c|}{ Charge: 0} \\
\hline $\mathrm{H}$ & -2.91577500 & 3.79776700 & 0.56158300 & \multicolumn{4}{|c|}{ Multiplicity: 1} \\
\hline $\mathrm{H}$ & -2.84534300 & 5.76916600 & -0.95231500 & \multicolumn{4}{|c|}{ Lowest Frequency: $-42.55 \mathrm{~cm}^{-1}$} \\
\hline $\mathrm{H}$ & -1.18297400 & 5.84561700 & -2.79492100 & \multicolumn{4}{|c|}{ Energy: $-\mathbf{4 4 2 6 . 7 7 7 8 6 2}$ Hartree } \\
\hline $\mathrm{H}$ & 0.45641800 & 4.00335600 & -3.08434400 & & & & \\
\hline $\mathrm{H}$ & -0.03802800 & 1.23434100 & -3.40837200 & $\mathrm{Ni}$ & -0.31435400 & -0.30710700 & 0.37812400 \\
\hline $\mathrm{H}$ & 1.69737000 & 1.05131000 & -5.06631600 & $\mathrm{P}$ & -2.35409100 & 0.12667100 & -0.23109100 \\
\hline $\mathrm{H}$ & 3.93467100 & 0.25895700 & -5.78973200 & $\mathrm{P}$ & 1.77563100 & -0.66041300 & 0.99620700 \\
\hline $\mathrm{H}$ & 5.47830600 & -0.77190300 & -4.13896500 & $\mathrm{Si}$ & 0.84825700 & 0.83674300 & -1.17869800 \\
\hline $\mathrm{H}$ & 4.76906500 & -1.03166500 & -1.78013100 & $\mathrm{~N}$ & -0.03117200 & -1.94511300 & -0.70035200 \\
\hline $\mathrm{H}$ & -0.04926500 & -0.55549700 & 2.39628900 & $\mathrm{C}$ & -3.11719800 & -1.41090000 & -0.90154400 \\
\hline $\mathrm{H}$ & 0.88309100 & -0.26971100 & 4.66492500 & $\mathrm{C}$ & -2.32921100 & -2.36555800 & -1.57276900 \\
\hline $\mathrm{H}$ & 0.89811500 & 1.98004300 & 5.73341600 & $\mathrm{C}$ & -2.93426000 & -3.52985100 & -2.04879500 \\
\hline $\mathrm{H}$ & -0.06675600 & 3.92317000 & 4.53063200 & $\mathrm{C}$ & -4.29725700 & -3.75645000 & -1.89322400 \\
\hline $\mathrm{H}$ & -1.03607900 & 3.63088600 & 2.26970300 & $\mathrm{C}$ & -5.08412900 & -2.79716500 & -1.26514700 \\
\hline $\mathrm{H}$ & -3.39140900 & 0.78170400 & -1.34715900 & $\mathrm{C}$ & -4.49482200 & -1.63660500 & -0.77513000 \\
\hline $\mathrm{H}$ & -5.79038500 & 0.23270300 & -1.11687000 & $\mathrm{C}$ & -0.87294400 & -2.12000500 & -1.86838000 \\
\hline $\mathrm{H}$ & -6.81430900 & 0.05771900 & 1.14469600 & $\mathrm{C}$ & -3.49780300 & 0.55338200 & 1.13308300 \\
\hline $\mathrm{H}$ & -5.42637200 & 0.46378600 & 3.16147900 & $\mathrm{C}$ & -3.88079200 & 1.87136100 & 1.40702900 \\
\hline $\mathrm{H}$ & -3.02329400 & 0.99902700 & 2.93115000 & $\mathrm{C}$ & -4.67503500 & 2.16288700 & 2.51238800 \\
\hline $\mathrm{H}$ & 1.52480300 & 2.25109000 & 0.86193300 & $\mathrm{C}$ & -5.11022500 & 1.14268200 & 3.35575500 \\
\hline $\mathrm{H}$ & 2.81580100 & 3.90681800 & 2.16521300 & $\mathrm{C}$ & -4.73195300 & -0.17077200 & 3.09387300 \\
\hline $\mathrm{H}$ & 5.23416900 & 3.53153400 & 2.60653600 & $\mathrm{C}$ & -3.91864600 & -0.46149900 & 2.00350800 \\
\hline $\mathrm{H}$ & 6.33997100 & 1.48159500 & 1.74423000 & $\mathrm{C}$ & -2.72896200 & 1.38447800 & -1.50425800 \\
\hline $\mathrm{H}$ & 5.03829500 & -0.18857300 & 0.47653700 & $\mathrm{C}$ & -3.48158300 & 1.11170800 & -2.65054700 \\
\hline $\mathrm{H}$ & 3.11231300 & -1.24371100 & 2.24341100 & $\mathrm{C}$ & -3.69247300 & 2.10307400 & -3.60547000 \\
\hline $\mathrm{H}$ & 3.74981800 & -3.47483200 & 3.08649400 & $\mathrm{C}$ & -3.16059500 & 3.37689600 & -3.42636800 \\
\hline $\mathrm{H}$ & 3.84907000 & -5.41534200 & 1.53714000 & $\mathrm{C}$ & -2.40427300 & 3.65624100 & -2.29043500 \\
\hline $\mathrm{H}$ & 3.31234100 & -5.09839000 & -0.86762000 & $\mathrm{C}$ & -2.18001300 & 2.66360500 & -1.34316200 \\
\hline $\mathrm{H}$ & 2.68009500 & -2.86602200 & -1.71629200 & $\mathrm{C}$ & 2.09014300 & -2.27278100 & 0.32985400 \\
\hline $\mathrm{Ni}$ & 0.05683400 & 0.14181500 & -0.80848800 & $\mathrm{C}$ & 1.05619200 & -2.74377100 & -0.54526600 \\
\hline $\mathrm{Si}$ & -0.82155300 & -1.92476600 & -0.86411700 & $\mathrm{C}$ & 1.27968300 & -4.00152300 & -1.16869900 \\
\hline $\mathrm{H}$ & -0.13357600 & -0.28424200 & -2.26661400 & $\mathrm{C}$ & 2.43120000 & -4.72303400 & -0.92347400 \\
\hline $\mathrm{H}$ & 0.13811900 & -2.92057200 & -1.44283600 & $\mathrm{C}$ & 3.43099500 & -4.24798600 & -0.06189400 \\
\hline $\mathrm{C}$ & -1.10996100 & -2.54058500 & 0.89842300 & $\mathrm{C}$ & 3.25041300 & -3.02264300 & 0.55701700 \\
\hline $\mathrm{C}$ & -2.26933000 & -2.21529100 & 1.62234200 & $\mathrm{C}$ & 3.29405300 & 0.01942100 & 1.71303000 \\
\hline $\mathrm{C}$ & -0.08478800 & -3.21124100 & 1.58557300 & $\mathrm{C}$ & 3.24714400 & 0.72708000 & 2.92266400 \\
\hline $\mathrm{C}$ & -2.38797000 & -2.51489300 & 2.97707100 & $\mathrm{C}$ & 4.38417300 & 1.36815400 & 3.40143100 \\
\hline $\mathrm{H}$ & -3.09482400 & -1.72016300 & 1.11445100 & $\mathrm{C}$ & 5.57771700 & 1.30869900 & 2.68380100 \\
\hline $\mathrm{C}$ & -0.19510200 & -3.50983000 & 2.94187800 & $\mathrm{C}$ & 5.63297300 & 0.59845900 & 1.48672500 \\
\hline $\mathrm{H}$ & 0.81579800 & -3.50393700 & 1.04892000 & $\mathrm{C}$ & 4.49917800 & -0.03982500 & 0.99782700 \\
\hline $\mathrm{C}$ & -1.34439900 & -3.15300400 & 3.64510900 & $\mathrm{C}$ & 0.50797600 & -0.80902300 & 2.25709500 \\
\hline $\mathrm{H}$ & -3.29575400 & -2.24373500 & 3.51192700 & $\mathrm{C}$ & 0.19506700 & -2.03668600 & 2.89020900 \\
\hline $\mathrm{H}$ & 0.61839100 & -4.02548700 & 3.44822700 & $\mathrm{C}$ & -0.82585800 & -2.10385300 & 3.81381800 \\
\hline $\mathrm{H}$ & -1.43075600 & -3.37988500 & 4.70477600 & $\mathrm{C}$ & -1.58568100 & -0.95584500 & 4.11063800 \\
\hline $\mathrm{C}$ & -2.46151100 & -2.07481000 & -1.80814200 & $\mathrm{C}$ & -1.32578000 & 0.24188600 & 3.47796600 \\
\hline $\mathrm{C}$ & -2.73116000 & -1.31115500 & -2.95471900 & $\mathrm{C}$ & -0.29329400 & 0.34675000 & 2.51989600 \\
\hline $\mathrm{C}$ & -3.45514900 & -2.97728800 & -1.39483000 & $\mathrm{C}$ & 2.43735200 & 0.23064200 & -2.00831100 \\
\hline $\mathrm{C}$ & -3.92857500 & -1.43319400 & -3.65417000 & $\mathrm{C}$ & 3.63015500 & 0.96629800 & -1.91807300 \\
\hline $\mathrm{H}$ & -1.99076700 & -0.58965300 & -3.30185200 & $\mathrm{C}$ & 4.80096500 & 0.53215500 & -2.53621300 \\
\hline $\mathrm{C}$ & -4.65942200 & -3.10306700 & -2.08356600 & $\mathrm{C}$ & 4.80975700 & -0.66055800 & -3.25378000 \\
\hline
\end{tabular}




\begin{tabular}{|c|c|c|c|}
\hline $\mathrm{C}$ & 3.63420000 & -1.39984300 & -3.37257600 \\
\hline $\mathrm{C}$ & 2.46419200 & -0.94840800 & -2.77171400 \\
\hline $\mathrm{H}$ & -0.11310300 & 0.86630300 & -2.33115800 \\
\hline $\mathrm{H}$ & -2.31549400 & -4.26549000 & -2.56000500 \\
\hline $\mathrm{H}$ & -4.74309900 & -4.67293800 & -2.26991800 \\
\hline $\mathrm{H}$ & -6.15475100 & -2.94606000 & -1.15671000 \\
\hline $\mathrm{H}$ & -5.11600000 & -0.88917600 & -0.28856300 \\
\hline $\mathrm{H}$ & -0.51069000 & -2.91747900 & -2.52930200 \\
\hline $\mathrm{H}$ & -0.81796000 & -1.19580600 & -2.47684500 \\
\hline $\mathrm{H}$ & -3.57107200 & 2.67636900 & 0.74639600 \\
\hline $\mathrm{H}$ & -4.96647500 & 3.19173300 & 2.70541700 \\
\hline $\mathrm{H}$ & -5.73995900 & 1.37165000 & 4.21083800 \\
\hline $\mathrm{H}$ & -5.05838800 & -0.97537400 & 3.74788800 \\
\hline $\mathrm{H}$ & -3.60893600 & -1.48815600 & 1.82058500 \\
\hline $\mathrm{H}$ & -3.89983900 & 0.12029100 & -2.80295600 \\
\hline $\mathrm{H}$ & -4.27429800 & 1.87590400 & -4.49455400 \\
\hline $\mathrm{H}$ & -3.32446300 & 4.14668400 & -4.17517400 \\
\hline $\mathrm{H}$ & -1.96502100 & 4.64030500 & -2.14883700 \\
\hline $\mathrm{H}$ & -1.54459100 & 2.87120000 & -0.48254100 \\
\hline $\mathrm{H}$ & 0.51939300 & -4.42372300 & -1.81943800 \\
\hline $\mathrm{H}$ & 2.55420500 & -5.69191900 & -1.40248100 \\
\hline $\mathrm{H}$ & 4.32324100 & -4.83572500 & 0.12783500 \\
\hline $\mathrm{H}$ & 4.00945900 & -2.63379900 & 1.23210200 \\
\hline $\mathrm{H}$ & 2.31572500 & 0.76812200 & 3.48365800 \\
\hline $\mathrm{H}$ & 4.34030600 & 1.91124000 & 4.34159600 \\
\hline $\mathrm{H}$ & 6.46383000 & 1.81265600 & 3.05961800 \\
\hline $\mathrm{H}$ & 6.56178400 & 0.54331400 & 0.92477200 \\
\hline $\mathrm{H}$ & 4.54331500 & -0.58756400 & 0.06053500 \\
\hline $\mathrm{H}$ & 0.78269800 & -2.91687500 & 2.63902000 \\
\hline $\mathrm{H}$ & -1.03921000 & -3.04223500 & 4.31809100 \\
\hline $\mathrm{H}$ & -2.38500600 & -1.01183200 & 4.84513100 \\
\hline $\mathrm{H}$ & -1.92509500 & 1.11838800 & 3.71252500 \\
\hline $\mathrm{H}$ & 0.06671300 & 1.34184500 & 2.26525400 \\
\hline $\mathrm{H}$ & 3.64552400 & 1.89195800 & -1.34412700 \\
\hline $\mathrm{H}$ & 5.71002800 & 1.12327700 & -2.44742300 \\
\hline $\mathrm{H}$ & 5.72487900 & -1.00960400 & -3.72539300 \\
\hline $\mathrm{H}$ & 3.62768300 & -2.32904100 & -3.93723800 \\
\hline $\mathrm{H}$ & 1.55431600 & -1.53377100 & -2.88917400 \\
\hline $\mathrm{C}$ & 1.17757800 & 2.64328400 & -0.72659300 \\
\hline $\mathrm{C}$ & 1.64832200 & 3.04056900 & 0.53265800 \\
\hline $\mathrm{C}$ & 0.98777100 & 3.64604400 & -1.69196400 \\
\hline $\mathrm{C}$ & 1.92198800 & 4.37549000 & 0.82220900 \\
\hline $\mathrm{H}$ & 1.82145200 & 2.29069100 & 1.30312800 \\
\hline $\mathrm{C}$ & 1.24954700 & 4.98350800 & -1.40852900 \\
\hline $\mathrm{H}$ & 0.62091700 & 3.37000000 & -2.68000300 \\
\hline $\mathrm{C}$ & 1.71743600 & 5.35217100 & -0.14848100 \\
\hline $\mathrm{H}$ & 2.29404400 & 4.65055000 & 1.80635800 \\
\hline $\mathrm{H}$ & 1.09175800 & 5.74072700 & -2.17309500 \\
\hline $\mathrm{H}$ & 1.92329800 & 6.39584100 & 0.07413900 \\
\hline
\end{tabular}

\begin{tabular}{|c|c|c|c|}
\hline $\mathrm{P}$ & -0.96042800 & -1.76068300 & 0.12874000 \\
\hline $\mathrm{Si}$ & -1.62772100 & 1.74413600 & -0.15331900 \\
\hline $\mathrm{N}$ & 0.08614600 & 0.33679600 & 1.84855000 \\
\hline $\mathrm{C}$ & 2.97716100 & -0.06190200 & 1.01570000 \\
\hline $\mathrm{C}$ & 2.47710600 & 0.34522700 & 2.27564800 \\
\hline $\mathrm{C}$ & 3.13876900 & -0.08207300 & 3.42812100 \\
\hline $\mathrm{C}$ & 4.26227500 & -0.90122300 & 3.35811600 \\
\hline $\mathrm{C}$ & 4.74367900 & -1.30785500 & 2.11864000 \\
\hline $\mathrm{C}$ & 4.10322400 & -0.88773800 & 0.95554600 \\
\hline $\mathrm{C}$ & 1.18349900 & 1.12055100 & 2.38141300 \\
\hline $\mathrm{C}$ & 2.84474700 & -0.45188000 & -1.86513600 \\
\hline $\mathrm{C}$ & 2.20494800 & -1.54427300 & -2.45905600 \\
\hline $\mathrm{C}$ & 2.81170800 & -2.23022300 & -3.50816600 \\
\hline $\mathrm{C}$ & 4.05637000 & -1.82413200 & -3.98066300 \\
\hline $\mathrm{C}$ & 4.69807800 & -0.72989900 & -3.40210400 \\
\hline $\mathrm{C}$ & 4.09607000 & -0.04861600 & -2.35100200 \\
\hline $\mathrm{C}$ & 2.56240400 & 2.14133800 & -0.78504200 \\
\hline $\mathrm{C}$ & 3.29269600 & 2.90494500 & 0.13121900 \\
\hline $\mathrm{C}$ & 3.55851600 & 4.24987000 & -0.12555600 \\
\hline $\mathrm{C}$ & 3.11006200 & 4.84304200 & -1.30131300 \\
\hline $\mathrm{C}$ & 2.39230800 & 4.08529900 & -2.22711800 \\
\hline $\mathrm{C}$ & 2.11649300 & 2.74959200 & -1.96854500 \\
\hline $\mathrm{C}$ & -1.10618300 & -1.75705900 & 1.93317600 \\
\hline $\mathrm{C}$ & -0.41497100 & -0.69374900 & 2.59100600 \\
\hline $\mathrm{C}$ & -0.29311200 & -0.79214900 & 4.00232500 \\
\hline $\mathrm{C}$ & -0.86772000 & -1.83907900 & 4.70028600 \\
\hline $\mathrm{C}$ & -1.56201900 & -2.86301700 & 4.04746300 \\
\hline $\mathrm{C}$ & -1.65180600 & -2.81665100 & 2.66331100 \\
\hline $\mathrm{C}$ & -2.57640200 & -2.20969200 & -0.58016900 \\
\hline $\mathrm{C}$ & -2.66139000 & -2.45352600 & -1.95997000 \\
\hline $\mathrm{C}$ & -3.87629400 & -2.77760000 & -2.55279000 \\
\hline $\mathrm{C}$ & -5.03570900 & -2.83146500 & -1.78117100 \\
\hline $\mathrm{C}$ & -4.97160200 & -2.54005700 & -0.42188700 \\
\hline $\mathrm{C}$ & -3.75337400 & -2.23250700 & 0.17668000 \\
\hline $\mathrm{C}$ & 0.10137500 & -3.23804600 & -0.14812900 \\
\hline $\mathrm{C}$ & -0.16727900 & -4.30270600 & -1.01250800 \\
\hline $\mathrm{C}$ & 0.78367700 & -5.30208300 & -1.22048900 \\
\hline $\mathrm{C}$ & 2.01062700 & -5.25592900 & -0.56749700 \\
\hline $\mathrm{C}$ & 2.28125200 & -4.20689800 & 0.31114100 \\
\hline $\mathrm{C}$ & 1.33731100 & -3.21098200 & 0.51820800 \\
\hline $\mathrm{C}$ & -1.47631100 & 3.59394500 & 0.11651600 \\
\hline $\mathrm{C}$ & -2.58883300 & 4.45524900 & 0.10002500 \\
\hline $\mathrm{C}$ & -2.44294400 & 5.82162500 & 0.31380300 \\
\hline $\mathrm{C}$ & -1.17812200 & 6.36061700 & 0.54040400 \\
\hline $\mathrm{C}$ & -0.06029500 & 5.52960200 & 0.55226700 \\
\hline $\mathrm{C}$ & -0.21128000 & 4.16289700 & 0.34671300 \\
\hline $\mathrm{H}$ & -0.75383000 & 1.06660700 & -1.37554300 \\
\hline $\mathrm{H}$ & 2.75141100 & 0.22779600 & 4.39695500 \\
\hline $\mathrm{H}$ & 4.75308900 & -1.22825800 & 4.27078900 \\
\hline $\mathrm{H}$ & 5.61511900 & -1.95354000 & 2.05227800 \\
\hline $\mathrm{H}$ & 4.47637700 & -1.21941200 & -0.01031100 \\
\hline $\mathrm{H}$ & 1.02261700 & 1.42110400 & 3.42755100 \\
\hline $\mathrm{H}$ & 1.24019300 & 2.05639800 & 1.80830600 \\
\hline $\mathrm{H}$ & 1.22821000 & -1.85320200 & -2.09188000 \\
\hline $\mathrm{H}$ & 2.30631900 & -3.08104300 & -3.95725300 \\
\hline $\mathrm{H}$ & 4.52661100 & -2.35693300 & -4.80269500 \\
\hline $\mathrm{H}$ & 5.66758400 & -0.40739600 & -3.77216700 \\
\hline $\mathrm{H}$ & 4.59420200 & 0.80798500 & -1.90030400 \\
\hline
\end{tabular}




$\begin{array}{lrrrlrrr}\mathrm{H} & 3.65464500 & 2.44781900 & 1.04950200 & \mathrm{H} & 1.55703600 & -2.39490200 & 1.20750200 \\ \mathrm{H} & 4.12457400 & 4.83186100 & 0.59734100 & \mathrm{H} & -3.58000700 & 4.05001900 & -0.09127400 \\ \mathrm{H} & 3.31666200 & 5.89148600 & -1.49776600 & \mathrm{H} & -3.31549500 & 6.46925800 & 0.29741200 \\ \mathrm{H} & 2.03875200 & 4.54109700 & -3.14790800 & \mathrm{H} & -1.06385100 & 7.42932200 & 0.70329300 \\ \mathrm{H} & 1.53900200 & 2.16572300 & -2.68409600 & \mathrm{H} & 0.93089800 & 5.94338400 & 0.71936300 \\ \mathrm{H} & 0.24252700 & -0.02319400 & 4.55065200 & \mathrm{H} & 0.66997200 & 3.52399000 & 0.34889900 \\ \mathrm{H} & -0.76452000 & -1.86422900 & 5.78311700 & \mathrm{C} & -3.42688800 & 1.38141100 & -0.50432500 \\ \mathrm{H} & -1.99579400 & -3.68645700 & 4.60583100 & \mathrm{C} & -4.43580300 & 1.65456100 & 0.43625500 \\ \mathrm{H} & -2.13876900 & -3.62778700 & 2.12277500 & \mathrm{C} & -3.80527200 & 0.78617600 & -1.71884600 \\ \mathrm{H} & -1.76155300 & -2.38472200 & -2.57045100 & \mathrm{C} & -5.76920600 & 1.36350200 & 0.16594800 \\ \mathrm{H} & -3.92021200 & -2.97829100 & -3.62034700 & \mathrm{H} & -4.17461500 & 2.10241400 & 1.39453900 \\ \mathrm{H} & -5.98846400 & -3.07698900 & -2.24329600 & \mathrm{C} & -5.14005700 & 0.51785700 & -2.00177100 \\ \mathrm{H} & -5.87679800 & -2.54742000 & 0.17975200 & \mathrm{H} & -3.04234800 & 0.53122700 & -2.45354400 \\ \mathrm{H} & -3.71161400 & -1.99953500 & 1.23750400 & \mathrm{C} & -6.12479800 & 0.80550200 & -1.05988700 \\ \mathrm{H} & -1.12550400 & -4.36428000 & -1.52150100 & \mathrm{H} & -6.53251400 & 1.57731100 & 0.90966300 \\ \mathrm{H} & 0.55584900 & -6.12465300 & -1.89413100 & \mathrm{H} & -5.41056300 & 0.06600600 & -2.95270500 \\ \mathrm{H} & 2.75018100 & -6.03371800 & -0.73603700 & \mathrm{H} & -7.16668400 & 0.58434900 & -1.27652700 \\ \mathrm{H} & 3.23137500 & -4.16344800 & 0.83801700 & & & & \end{array}$




\section{References}

[S1] Verhoeven, D. G. A.; Negenman, H. N.; Orsino, A. F.; Lutz, M.; Moret, M. -E., Versatile Coordination and $\mathrm{C}-\mathrm{C}$ Coupling of Diphosphine-Tethered Imine Ligands with $\mathrm{Ni}(\mathrm{II})$ and $\mathrm{Ni}(0)$. Inorg. Chem., 2018, 57(17), 10846-10856.

[S2] Schreurs, A. M. M.; Xian, X.; Kroon-Batenburg, L. M. J. J. Appl. Cryst., 2010, 43, 70-82.

[S3] Herbst-Irmer, R.; Sheldrick, G. M. Acta Cryst. 1998, B54, 443-449.

[S4] Sheldrick, G. M. SADABS and TWINABS, 2014, Universität Göttingen, Germany.

[S5] Sheldrick, G. M., SHELXT - Integrated space-group and crystal-structure determination, Acta Cryst., 2015, A71, 3-8.

[S6] Sheldrick, G. M., Crystal structure refinement with SHELXL, Acta Cryst., 2015, C71, 3-8.

[S7] Spek, A. L., Structure validation in chemical crystallography Acta Cryst., 2009, D65, 148-155.

[S8] Spek, A. L. Acta Cryst., 2015, C71, 9-18.

[S9] All calculations are performed with Gaussian 09, Revision D.01: Frish, M. J.; Trucks, G. W.; Schlegel, H. B.; Scuseria, G. E.; Robb, M. A.; Cheeseman, J. R.; Scalmani, G.; Barone, V.; Mennucci, B.; Petersson, G. A.; Nakatsuji, H.; Caricato, M.; Li, X.; Hratchian, H. P.; Izmaylov, A. F.; Bloino, J.; Zheng, G.; Sonnenberg, J. L.; Hada, M.; Ehara, M.; Toyota, K.; Fukuda, R.; Hasegawa, J.; Ishida, M.; Nakajima, T.; Honda, Y.; Kitao, O.; Nakai, H.; Vreven, T.; Montgomery, J. A.; Peralta, J. E.; Ogliaro, F.; Bearpark, M.; Heyd, J. J.; Brothers, E.; Kudin, K. N.; Staroverov, V. N.; Kobayashi, R.; Normand, J.; Raghavachari, K.; Rendell, A.; Burant, J. C.; Iyengar, S. S.; Tomasi, J.; Cossi, M.; Rega, N.; Millam, J. M.; Klene, M.; Knox, J. E.; Cross, J. B.; Bakken, V.; Amado, C.; Jaramillo, J.; Gomperts, R.; Stratmann, R. E.; Yazyev, O.; Austin, A. J.; Cammi, R.; Pomelli, C.; Ochterski, J. W.; Martin, R. L.; Morokuma, K.; Zakrzewski, V. G.; Voth, G. A.; Salvador, P.; Dannenberg, J. J.; Dapprich, S.; Daniels, A. D.; Farkas, Ö.; Foresman, J. B.; Ortiz, V.; Cioslowski, J.; Fox, D. J. Gaussian 09, Revision D.01; Gaussian, Inc.: Wallingford, CT, 2013.

[S10] Grimme, S.; Antony, J.; Ehrlich, S.; Krieg, H. A Consistent and Accurate Ab Initio Parametrization of Density Functional Dispersion Correction (DFT-D) for the 94 Elements HPu. J. Chem. Phys. 2010, 132, 154104-154119.

[S11] Sperger, T.; Sanhueza, I. A.; Kalvet, I.; Schoenebeck, F. Computational Studies of Synthetically Relevant Homogeneous Organometallic Catalysis Involving Ni, Pd, Ir, and Rh: An Overview of Commonly Employed DFT Methods and Mechanistic Insights. Chem. Rev. 2015, 115, 95329586. 